Florida International University FIU Digital Commons

FIU Electronic Theses and Dissertations

University Graduate School

9-1-2015

\title{
Modeling a Phosphorus Credit Trading Program in the Lake Okeechobee Watershed
}

Juliana Corrales

Florida International University, jcorr028@fiu.edu

DOI: $10.25148 /$ etd.FIDC000190

Follow this and additional works at: https://digitalcommons.fiu.edu/etd

Part of the Environmental Monitoring Commons, Hydrology Commons, Natural Resource Economics Commons, Natural Resources Management and Policy Commons, and the Water Resource Management Commons

\section{Recommended Citation}

Corrales, Juliana, "Modeling a Phosphorus Credit Trading Program in the Lake Okeechobee Watershed" (2015). FIU Electronic Theses and Dissertations. 2294.

https://digitalcommons.fiu.edu/etd/2294

This work is brought to you for free and open access by the University Graduate School at FIU Digital Commons. It has been accepted for inclusion in FIU Electronic Theses and Dissertations by an authorized administrator of FIU Digital Commons. For more information, please contact dcc@fiu.edu. 


\section{FLORIDA INTERNATIONAL UNIVERSITY}

Miami, Florida

MODELING A PHOSPHORUS CREDIT TRADING PROGRAM IN THE LAKE OKEECHOBEE WATERSHED

A dissertation submitted in partial fulfillment of the requirements for the degree of DOCTOR OF PHILOSOPHY

in

\section{EARTH SYSTEMS SCIENCE}

by

Juliana Corrales 
To: Dean Michael R. Heithaus

College of Arts and Sciences

This dissertation, written by Juliana Corrales, and entitled Modeling a Phosphorus Credit Trading Program in the Lake Okeechobee Watershed, having been approved in respect to style and intellectual content, is referred to you for judgment.

We have read this dissertation and recommend that it be approved.

Mahadev G. Bhat

Michael C. Sukop

Dean Whitman

Francisco R. Garcia

G. Melodie Naja

Fernando Miralles-Wilhelm, Major Professor

Date of Defense: September 1, 2015

The dissertation of Juliana Corrales is approved.

Dean Michael R. Heithaus

College of Arts and Sciences

Dean Lakshmi N. Reddi

University Graduate School

Florida International University, 2015 


\section{DEDICATION}

This dissertation is dedicated to my parents, Ivan and Libia, for giving me the sense of perseverance, patience, dedication, and responsibility, which prepared me to accomplish this work. 


\section{ACKNOWLEDGMENTS}

I would like to express my deepest gratitude to Dr. Melodie Naja for her excellent guidance, patience, caring, and continuous encouragement. I am forever thankful to her for sharing expertise and for her commitment throughout my doctoral studies. I also would like to sincerely thank my advisor, Dr. Fernando Miralles-Wilhelm, for his support, for challenging my critical thinking through homework assignments and class projects, and for his genuine interest in my professional career development. I would like to express my gratitude to Dr. Mahavev Bhat for providing me with valuable knowledge in environmental economics and for his time devoted to one-onone meetings that help me to better understand essential economic concepts for the development of this dissertation. I am also extremely thankful to my other committee members, Dr. Michael Sukop, Dr. Reinaldo Garcia, and Dr. Dean Whitman for their teaching, constructive comments, and helpful suggestions. All their contributions were deeply appreciated and of significant importance to enhance this dissertation.

I would also take this opportunity to express my profound gratitude to my family for their unconditional support, love, and motivation throughout my entire doctorate program.

Finally, I would like to acknowledge the Everglades Foundation for their financial support during my PhD studies and for providing me with an excellent atmosphere for conducting research. I am very honored to have received their Fellowship for three consecutive years. Furthermore, I would also like to thank Florida International University for supporting me through the Dissertation Year Fellowship which helped me to timely complete this dissertation. 


\title{
ABSTRACT OF THE DISSERTATION
}

\section{MODELING A PHOSPHORUS CREDIT TRADING PROGRAM IN THE LAKE \\ OKEECHOBEE WATERSHED}

by

\author{
Juliana Corrales
}

Florida International University, 2015

Miami, Florida

\section{Professor Fernando Miralles-Wilhelm, Major Professor}

Lake Okeechobee is the largest lake in the southeastern United States and is a central component of the hydrology and environment of the Everglades ecosystem in South Florida. The natural state of the lake has been degraded as wetlands and natural habitats in the Lake Okeechobee watershed have been replaced with farms, urban areas, and dairy operations. Excessive phosphorus loadings from these diverse sources have been identified as the leading causes of the lake's impairment. For more than four decades, many resources have been allocated to regional and local restoration efforts to reduce phosphorus loadings into the lake. However, phosphorus loadings have not decreased and the recovery of the lake could take more time, particularly with today's limited local budgets.

Market-based instruments, such as water quality trading programs, have emerged over the past decades to cost-effectively achieve water quality objectives in impaired watersheds. The main objective of this dissertation was to assess the environmental and economic benefits of implementing a phosphorus trading program in Lake Okeechobee watershed, compared to a conventional command-and-control approach. A comprehensive literature overview of nationally and internationally implemented trading programs was conducted to highlight advantages and challenges of these 
programs towards achieving water quality goals, and to outline the essential elements of a successful program. Furthermore, a modeling framework, integrating a hydrologic-water quality model with an economic model, was developed to assess the potential cost savings that trading might offer over a command-and-control approach. The modeling framework was applied in three priority basins of the Lake Okeechobee watershed. In each case, while developing trading scenarios to achieve phosphorus load reduction targets, the trading program was less expensive than the conventional command-and-control approach.

This research provided the foundation for stakeholders to better understand whether water quality trading has the potential to work in the Lake Okeechobee watershed and to facilitate the development of a pilot program. In addition, it offered some insights on the potential economic opportunities that pollution sources would have by participating in the trading program. The modeling framework developed in this dissertation could facilitate the assessment of future water quality trading programs in other watersheds. 


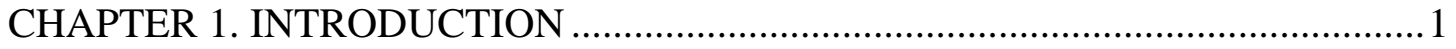

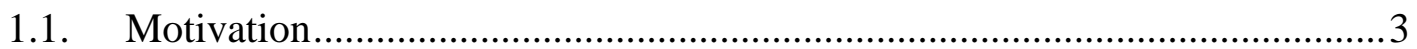

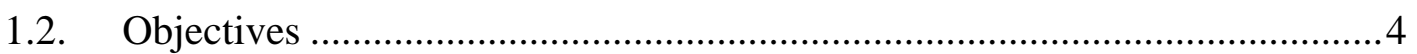

1.3. Dissertation Structure.............................................................................

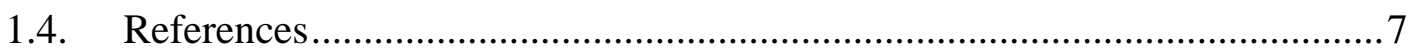

\section{CHAPTER 2. WATER QUALITY TRADING PROGRAMS TOWARDS}

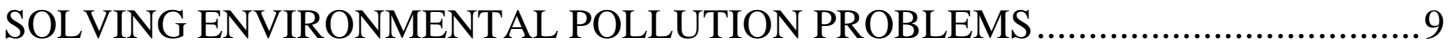

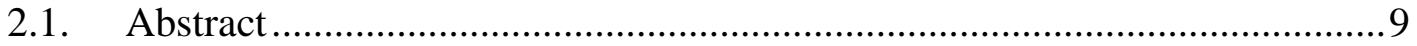

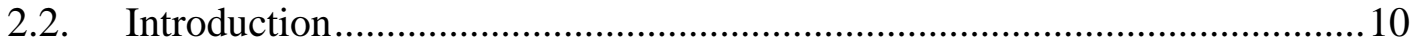

2.3. Advantages of a Water Quality Trading Approach ....................................12

2.4. Challenges Associated With Water Quality Trading Programs ....................15

2.5. Elements of a Water Quality Trading Program ..........................................22

2.6. Meta-Analysis of Water Quality Trading Programs ......................................31

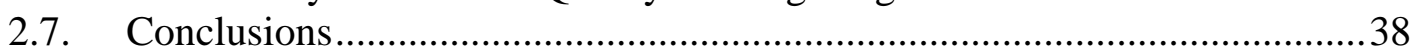

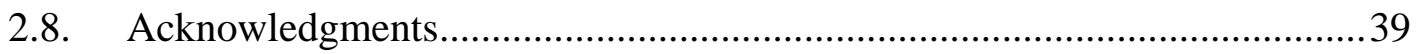

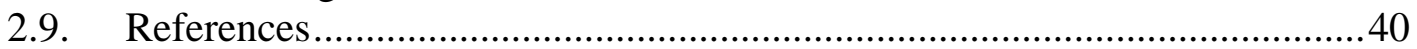

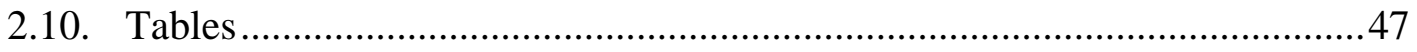

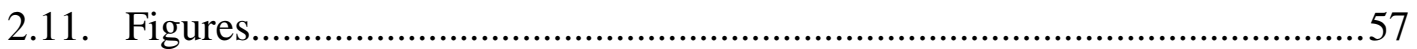

\section{CHAPTER 3. MODELING A PHOSPHORUS CREDIT TRADING PROGRAM}

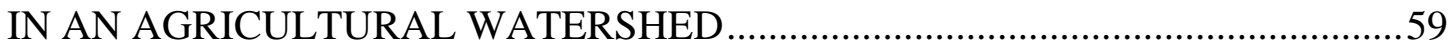

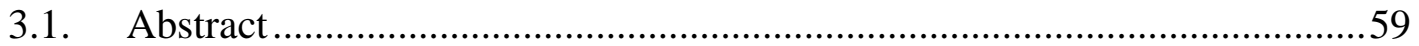

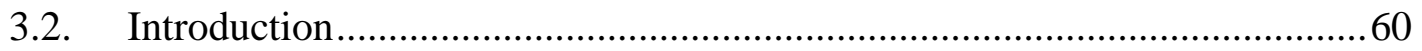

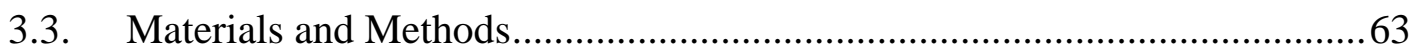

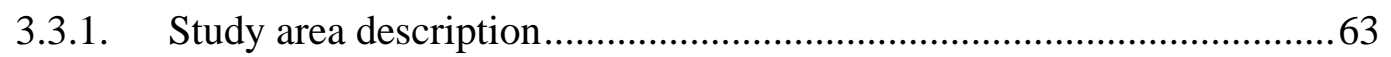

3.3.2. Hydrology and water quality modeling ............................................64

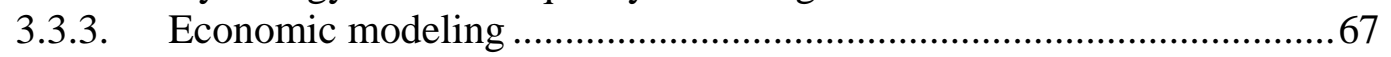

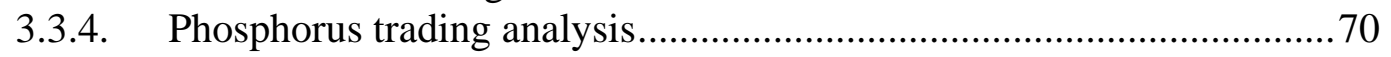

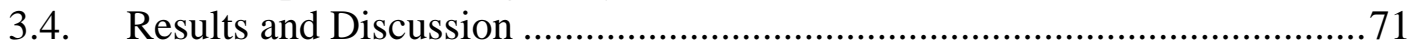

3.4.1. Hydrology and water quality modeling .............................................. 71

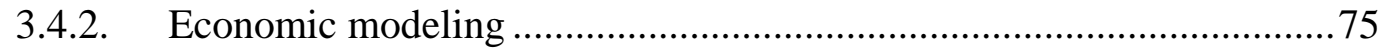

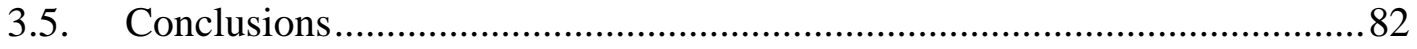

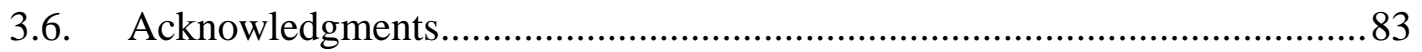

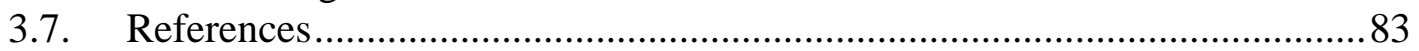

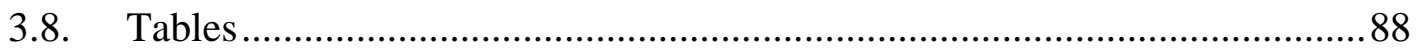

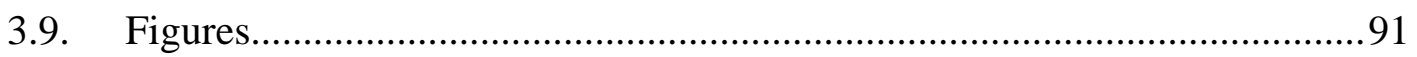

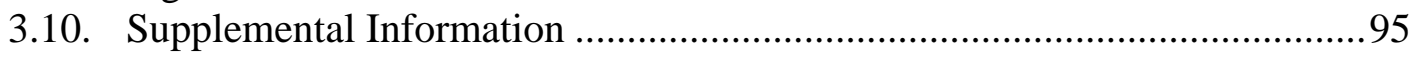


CHAPTER 4. WATER QUALITY TRADING OPPORTUNITIES IN TWO SUBWATERSHEDS IN THE NORTHERN LAKE OKEECHOBEE WATERSHED...112

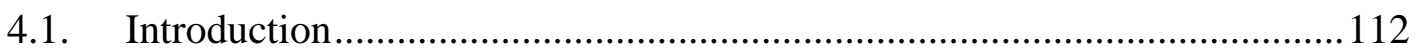

4.2. Materials and Methods.........................................................................115

4.2.1. Study areas description ......................................................................115

4.2.2. Identification of sources of phosphorus and quantification of loadings ……...............................................................................117

4.2.3. Determination of attenuation rates and delivery trading ratios.............120

4.2.4. Phosphorus abatement approaches ........................................................122

4.2.5. Setting the cap of a water quality trading program through an optimization process .........................................................................125

4.3. Results and Discussion .........................................................................127

4.3.1. Phosphorus loads by source ...............................................................127

4.3.2. Attenuation rates and delivery trading ratios ......................................129

4.3.3. Setting the cap of a WQTP scenario in the UK and TCNS subwatersheds ......................................................................................130

4.3.4. Comparing CAC and LCA scenarios.................................................135

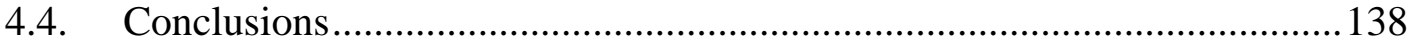

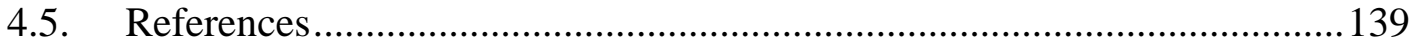

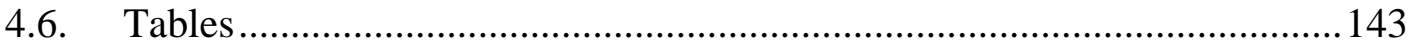

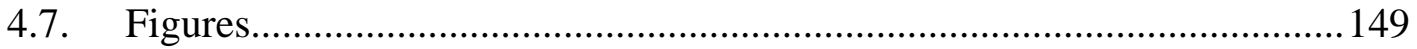

CHAPTER 5. SUMMARY, CONCLUSIONS, AND RECOMMENDATIONS .....157

5.1. Summary and Conclusions ……………………………………………...157

5.2. Recommendations and Future Work ............................................................160

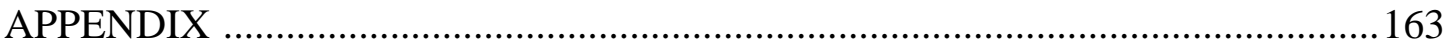

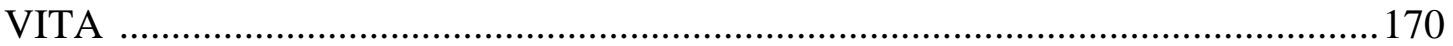




\section{LIST OF TABLES}

TABLE

PAGE

Table 2-1. Advantages of water quality trading programs. ........................................47

Table 2-2. Challenges of water quality trading programs.........................................47

Table 2-3. Summary of some examples of water quality trading programs................48

Table 2-4. Correlation between elements of a water quality trading program and the program success, involving point and agricultural nonpoint

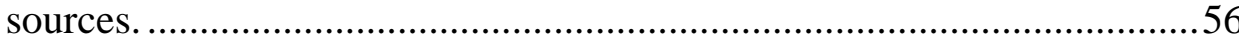

Table 3-1. Average annual Total Phosphorus (TP) load per land use type. ................88

Table 3-2. Summary of credits bought and costs for the buyer sources. ......................89

Table 3-3. Summary of credits sold and costs for the seller sources..........................90

Table 3-S1. Best Management Practices (BMPs) description.................................. 104

Table 3-S2. Annual cost of implementing the three BMP types per land use and per area (\$ ha-1 yr-1) (from SWET, 2006)...........................................106

Table 3-S3. Best Management Practices (BMPs) efficiency - TP load reduction in percentage (\%) (from SWET, 2006) ..............................................106

Table 3-S4. Land use distribution per zone in the S-191 sub-basin (ha)...................107

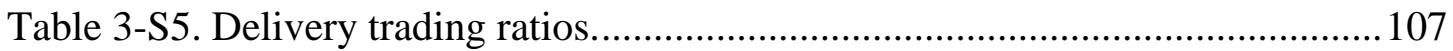

Table 3-S6. Total phosphorus load attenuated to the nearby stream per land use and per zone in the S-191 sub-basin (kg ha-1 yr-1).

Table 3-S7. Total phosphorus load attenuated to the nearby stream per land use after Best Management Practice (BMP) implementation under a Command-and-Control approach and a Least-Cost Abatement scenario.

Table 4-1. Land use data for the Upper Kissimmee (UK) and Taylor Creek/Nubbin Slough (TCNS) sub-watersheds

Table 4-2. Description of the variables used in the optimization model.

Table 4-3. Best management practices (BMPs) and advanced wastewater treatment (AWT) technologies total phosphorus (TP) reduction efficiencies (\%) and annual unit costs (\$ kg-1 reduced) for the Upper 
Kissimmee (UK) and Taylor Creek/Nubbin Slough (TCNS) subwatersheds.

Table 4-4. Average Annual Total Phosphorus (TP) load per source in the Upper Kissimmee (UK) sub-watershed.

Table 4-5. Average Annual Total Phosphorus (TP) load per source in the Taylor Creek/Nubbin Slough (TCNS) sub-watershed.

Table 4-6. Total annual costs and corresponding potential cost savings for the command-and-control (CAC) and the least-cost abatement (LCA) approaches for achieving different TP load reduction targets in the Upper Kissimmee (UK) sub-watershed.

Table 4-7. Total annual costs and corresponding potential cost savings for the command-and-control (CAC) and the least-cost abatement (LCA) approaches for achieving different TP load reduction targets in the Taylor Creek/Nubbin Slough (TCNS) sub-watershed.

Table 4-8. Number of credits available to sell and number of potential sellers and buyers for different TP load reduction targets in the Upper Kissimmee (UK) sub-watershed.

Table 4-9. Number of credits available to sell and number of potential sellers and buyers for different TP load reduction targets in the Taylor Creek/Nubbin Slough (TCNS) sub-watershed.

Table 4-10. Net cost savings of the WQTP for the Upper Kissimmee (UK) and Taylor Creek/ Nubbin Slough (TCNS) sub-watersheds using the selected TP reduction targets 


\section{LIST OF FIGURES}

FIGURE

PAGE

Figure 2-1. Key benefits and challenges of water quality trading programs with some of the suggested solutions.

Figure 2-2. Key elements of a water quality trading program, pre and post trading in a temporal perspective.

Figure 2-3. Locations of some water quality trading programs in North America. The remaining water quality trading program discussed is located in Australia.

Figure 3-1. (a) Maps of Florida, Lake Okeechobee watershed, and S-191 subbasin study area. (b) S-191 sub-basin hydrography and rainfall stations.

Figure 3-2. Total Phosphorus (TP) loading spatial distribution (kg ha-1 yr-1): (a) un-attenuated at the farm level, (b) attenuated to the nearby stream, (c) attenuated to the sub-basin outlet. (d) Land use classification in the S-191 sub-basin.

Figure 3-3. Zone classification of the phosphorus attenuation factors.

Figure 3-4. (a) Costs and cost savings (in million dollars per year) of achieving different TP loading caps at the zone level under a Command-andControl approach and a Least-Cost Abatement scenario. (b) Credit price (\$) determination.

Figure 3-S1. Diagram illustrating the methodology followed to: (a) estimate the total phosphorus (TP) loadings before implementation of Best Management Practices (BMPs) at each zone $i$ and land use $j$ as well as the trading ratios (TR) at each zone $i$, and (b) assess the trading program cost savings.

Figure 3-S2. (a) Best Management Practices (BMP) selected under a Commandand-Control approach and (b) under a Least-Cost Abatement scenario. C stands for citrus, IP for improved pastures, UP for unimproved pastures, RWP for rangeland and wooded pastures, D for dairies, FC for field crops, O for ornamentals, RC for row crops, $\mathrm{S}$ for sod, and $\mathrm{U}$ for urban

Figure 3-S3. Credit price identification from the Marginal Abatement Cost (MAC) curves.

Figure 4-1. Lake Okeechobee watershed (LOW) detailing the sub-watershed boundaries and the major hydrologic components. 
Figure 4-2. Study areas (a) Upper Kissimmee (UK) and (b) Taylor Creek/Nubbin Slough (TCNS) illustrating the major hydrologic components and the rainfall stations.

Figure 4-3. Location of selected point sources in the (a) Upper Kissimmee (UK) and (b) Taylor Creek/Nubbin Slough (TCNS) sub-watersheds

Figure 4-4. Land use distribution in the (a) Upper Kissimmee (UK) and (b) Taylor Creek/Nubbin Slough (TCNS) sub-watersheds.

Figure 4-5. Total Phosphorus (TP) loading spatial distribution (kg ha-1 yr-1) at the source level in the (a) Upper Kissimmee (UK) and (b) Taylor Creek/Nubbin Slough (TCNS) sub-watersheds.

Figure 4-6. Zone classification of the phosphorus attenuation factors in the (a) Upper Kissimmee (UK) and (b) Taylor Creek/Nubbin Slough (TCNS) sub-watersheds.

Figure 4-7. Total annual costs (\$ million yr-1) for achieving different TP load reduction targets in the (a) Upper Kissimmee (UK) and (b) Taylor Creek/Nubbin Slough (TCNS) sub-watersheds.

Figure 4-8. Credit prices ( $\$ \mathrm{~kg}-1$ of TP reduced) for achieving different TP load reduction targets in the (a) Upper Kissimmee (UK) and (b) Taylor Creek/Nubbin Slough (TCNS) sub-watersheds

Figure 4-9. Summary of the four factors influencing the selection of the cap level for the Upper Kissimmee (UK) and Taylor Creek/Nubbin Slough (TCNS) sub-watersheds

Figure 4-10. Best management practices (BMP) and advanced wastewater treatment (AWT) technologies selected in the Upper Kissimmee (UK) sub-watershed under the (a) CAC and (b) LCA approaches for meeting a preset $46 \%$ TP load reduction target. C stands for citrus, IP for improved pastures, UP for unimproved pastures, RWP for rangeland and wooded pastures, D for dairies, FC for field crops, $\mathrm{O}$ for ornamentals, RC for row crops, SO for sod, U for urban, and WWTF for wastewater treatment facilities.

Figure 4-11. Best management practices (BMP) selected in the Taylor Creek/Nubbin Slough (TCNS) sub-watershed under the (a) CAC and (b) LCA approaches for meeting a preset 32\% TP load reduction target. C stands for citrus, IP for improved pastures, UP for unimproved pastures, $\mathrm{S}$ for sugarcane, CAFOs for concentrated animal food operations, FC for field crops, O for ornamentals, RC for row crops, SO for sod, and U for urban. 


\section{LIST OF ABBREVIATIONS}

Advanced Wastewater Treatment

AWT

Agricultural Policy/Environmental Extender

APEX

Basin Management Action Plan

BMAP

Best Management Practices

BMP

Binomial Correlation Coefficients

BBC

Chesapeake Bay Program Nutrient Trading Negotiation Team

CPNT

Clean Water Act

CWA

Command-and-control

CAC

Concentrated Animal Feeding Operations

CAFO

Connecticut Department of Environmental Protection

CTDEP

Florida Department of Environmental Protection

FDEP

Florida Land Use, Cover, and Forms Classification System

FLUCCS

General Algebraic Modeling System

GAMS

Geographic Information System

GIS

Goodness-of-Fit

GOF

Incentive-based

IB

Lake Okeechobee

LO

Lake Okeechobee Watershed

LOW

Least-cost Abatement

LCA

Marginal Abatement Cost

MAC

Mean Bias Error

MBE

Miami Conservancy District

MCD

Million Gallons per Day

MGD

Municipal Separate Stormwater Sewer System

MS4s 
Nash-Sutcliffe Coefficient of Efficiency

National Pollutant Discharge Elimination System

NPDES

Natural Resources Conservation Service

NRCS

Nonpoint Sources

NPS

Particulate Phosphorus

PP

Pennsylvania Department of Environmental Protection

PADEP

Point Sources

PS

Root Mean Square Error

RMSE

Soil and Water Assessment Tool

SWAT

Soil and Water Engineering Technology, Inc.

SWET

Soluble Phosphorus

SP

South Florida Water Management District

SFWMD

Taylor Creek/Nubbin Slough

TCNS

Total Maximum Daily Load

TMDL

Total Phosphorus

TP

Trading Ratios

TR

U.S. Department of Agriculture

USDA

U.S. Environmental Protection Agency

USEPA

Upper Kissimmee

UK

Virginia Department of Environmental Quality

VDEQ

Wastewater Treatment Facilities

WWTF

Water Quality Trading

WQT

Water Quality Trading Programs

WQTP

Watershed Assessment Model

WAM

World Resource Institute

WRI 


\section{CHAPTER 1}

\section{INTRODUCTION}

Nutrient pollution, caused by excess nitrogen and phosphorus inputs to the environment, is one of the world's most challenging, widespread, and costly environmental problems. For decades, the increase of nutrient enrichment has threatened the ecological integrity and economic sustainability of many rivers, lakes, and coastal waters. The proliferation of nutrients have been seen in Lake Ladoga and the Baltic Sea in Europe (Drabkova et al., 1996; Paerl and Huisman, 2008), Lake Victoria in Africa, Lake Taihu in Asia (Paerl et al., 2011), and the Amazon River and Lake Okeechobee in the Americas (Demaster and Pope, 1996; Havens and Gawlik, 2005). In the United States alone, nutrient pollution ranks in the top three leading causes of impairment of rivers and lakes, affecting the public water supply, aquatic wildlife, and agricultural, recreational, and industrial activities (USEPA, 2009). Freshwater nutrient pollution is estimated to cost the United States at least \$ 2.2 billion annually (Dodds et al., 2009). Since the establishment of the Clean Water Act (CWA), considerable efforts have been adopted towards reducing nutrient pollution from point sources. However, with rapid urban and agricultural development, it seems that water body impairments that result from excessive nutrient inputs are a neverending environmental problem. Part of this environmental problem is the complex nature of nutrient pollution and the challenging task of controlling nonpoint emissions (Ouyang et al., 2009; Zhang and Huang, 2011). Undoubtedly, another part of the problem is today's national and local economic constraints (Faeth, 2000).

When devising environmental policy instruments for solving environmental problems, policymakers have the difficult task of evaluating different policies 
strategies using several factors, such as efficiency, cost-effectiveness, fairness (distributional equity of benefits or costs), ability to address uncertainties, and political feasibility (Goulder and Parry, 2008). In the water quality arena, the environmental policies currently implemented have been heavily dominated by traditional command-and-control (CAC) or regulatory approaches (Harrington and Morgenstern, 2004). However, there has been a notable increase in popularity of incentive-based (IB) mechanisms to address water body impairments. One widely discussed IB approach is the cap-and-trade system (also known as a tradeable permit program) (Goodstein, 2011). The economic advantage that the IB approach offers over CAC approaches is the main reason for increased interest in this alternative tool (Stavins and Whitehead, 1996). Certainly, the successful experience of reducing sulfur dioxide and other air emissions using IB instruments has helped to boost the expectations for the implementation of cap-and-trade tools in the water quality field (Field and Field, 2006).

Water quality trading is cost effective since pollution sources with low abatement costs can reduce their emissions beyond imposed limits and generate credits that can be sold to other sources with high treatment costs. Allowing the trade of credits reduces the overall costs of pollution control, while attaining water quality goals (Faeth, 2000). In addition, trading offers pollution sources the flexibility to control their emissions while exploring and implementing innovative technologies and practices for pollution control (Goodstein, 2011). Water quality trading programs (WQTPs) have been implemented in different countries, such as Australia, Canada, the United States, and New Zealand (Selman et al., 2009; Shortle, 2013). In a survey conducted by Selman et al. (2009), 57 WQTPs were identified worldwide, 51 of which are located in the United States. The implemented WQTPs have been evaluated 
in several reports and articles (Borghesi, 2014; Mariola, 2009; Newburn and Woodward, 2012; USEPA, 2009), and while some studies reported successful outcomes, most of the papers underlined the limited trading activities that have actually taken place. Although trading is generally driven by regulations, it is incentivized by economics, which means that if there is not enough financial attractiveness, pollution sources might not be eager to participate in a trading program (USEPA, 2003). Therefore, it is critical that promoters of WQT understand and overcome the potential challenges and limitations associated with this type of program. It is widely accepted that WQTPs are not a panacea for water pollution control, and their success or failure to provide cost-effective water quality improvements will depend on how the program is designed and implemented (Newell and Stavins, 2003; Shortle, 2013). Therefore, before investing resources to implement a WQTP, it is important to conduct a feasibility analysis to determine the environmental and economic benefits of a trading program for improving water quality in a specific watershed. The feasibility analysis would also give insight to prospective trading entities about the economic opportunities they would have by participating in a trading program.

\subsection{Motivation}

Recognizing the economic prospects of IB tools over CAC approaches, the motivation of this dissertation is to investigate the feasibility of implementing a WQTP in an impaired freshwater body in the United States. With a surface area of 1,890 $\mathrm{km}^{2}$, Lake Okeechobee (LO) is the second largest freshwater lake in the contiguous United States. Located in South Florida, it constitutes a critical link between the Kissimmee River in the north, wetlands and bays in the south, and 
estuaries in the east and west. The natural state of the lake has been degraded as wetlands and natural habitats in the Lake Okeechobee watershed (LOW) have been replaced with farms, urban areas, and dairy operations (Hiscock et al., 2003). Excessive phosphorus loadings from agriculture and livestock, municipal and industrial wastewater discharges, and urban stormwater runoff have been identified as the leading causes of the lake's impairment (FDEP, 2001). According to the 2015 South Florida Environmental Report, the annual average (2010 - 2014) total phosphorus (TP) loading discharged to LO is 442 metric tons (mtons) (Sharfstein et al., 2015). The TP entering the LO is about 302 mtons greater than the Total Maximum Daily Load (TMDL) of 140 mtons of TP per year mandated by the Florida Department of Environmental Protection (FDEP). For more than four decades, many resources have been allocated to regional and local restoration efforts to reduce nutrient loadings to the lake (Havens and Gawlik, 2005). However, TP loadings to the lake have not significantly decreased and the recovery of the lake could take more time, particularly with today's limited local budgets. Therefore, it is important to investigate innovative economic incentives to address the phosphorus pollution problem in LOW.

\subsection{Objectives}

The main objective of the present dissertation was to assess the environmental and economic benefits of implementing a phosphorus trading program in the Lake Okeechobee watershed compared to a conventional regulatory command-and-control approach. In order to achieve this principal objective, the following specific objectives were identified: 
- Conduct a literature overview of worldwide water quality trading programs to 1) assess advantages of these programs towards achieving water quality goals, 2) identify challenges confronted during the design through the implementation phase, and 3) outline the essential elements of a successful program.

- Identify point and nonpoint phosphorus sources and estimate their associated TP loadings in two sub-watersheds within the Lake Okeechobee watershed, representing priority basins for phosphorus load controls and with different land use and hydrologic characteristics.

- Estimate attenuation ratios to account for biophysical processes within the stream network of the sub-watersheds and derive delivery trading ratios to support the phosphorus loading equivalence between trading sources at a different distance from the outlet of the sub-watershed.

- Develop an optimization model to identify the optimal combination of best management practices and technologies to be implemented in the sub-watersheds in order to minimize the cost of achieving a phosphorus reduction target.

- Develop trading scenarios in the sub-watersheds to evaluate the potential trading cost savings for achieving different phosphorus reduction targets and to determine whether the conditions exist to support the implementation of a water quality trading program involving point and nonpoint pollution sources.

\subsection{Dissertation Structure}

The remainder of this dissertation is organized in three main chapters. Each chapter takes the form of a research paper intended to be a stand-alone chapter, that has been either published or prepared for publication, and addresses one or several of the specific objectives identified above. 
Chapter 2, published in the Irrigation and Drainage Journal, provides a review of water quality trading programs around the world. This chapter identifies advantages, challenges, and essential elements for the design and implementation of a trading program. In addition, a meta-analysis is presented to prioritize the main factors driving the success of a trading program.

Chapter 3, published in the Journal of Environmental Management, describes a modeling framework integrating a hydrologic-water quality model with an economic model to assess the cost-benefits of a phosphorus water quality trading program. It also presents the first attempt to apply the developed modeling framework in an agricultural sub-basin within the Lake Okeechobee watershed.

Chapter 4, using the framework developed in Chapter 3, evaluates and compares the potential of a water quality trading program versus a command-and-control approach to cost-effectively achieve different phosphorus load reduction targets. This evaluation focuses on two sub-watersheds with different land use and hydrologic conditions within the Lake Okeechobee watershed. In addition, Chapter 4 presents an assessment of the effect of different caps on the trading program potential, while considering several factors, such as the least-cost solutions, credit prices, potential cost savings, and credit supply and demand.

Finally, a summary of this dissertation is presented in Chapter 5. Major conclusions and recommendations for future work are also provided. 


\subsection{References}

Borghesi, S., 2014. Water tradable permits: a review of theoretical and case studies, J. Environ. Plann. Manage. 57, 1305-1332.

Demaster, D.J., Pope, R.H., 1996. Nutrient dynamics in Amazon shelf waters: results from AMASSEDS, Cont. Shelf Res. 16, 263-289.

Dodds, W.K., Bouska, W.W., Eitzmann, J.L., Pilger, T.J., Pitts, K.L., Riley, A.J., Schloesser, J.T., Thornbrugh, D.J., 2009. Eutrophication of U.S. freshwaters: analysis of potential economic damages, Environ. Sci. Technol. 43, 12-19.

Drabkova, V., Rutnyantsev, V., Sergeeva, L., Slepukhina, T., 1996. Ecological problems of Lake Ladoga: causes and solutions, Hydrobiologia 322, 1-7.

Faeth, P., 2000. Fertile ground: Nutrient trading's potential to cost-effectively improve water quality, World Resources Institute, Washington, DC.

FDEP, 2001. Total maximum daily load for total phosphorus Lake Okeechobee, Florida, Florida Department of Environmental Protection, Atlanta, GA.

Field, B.C., Field, M.K., 2006. Environmental Economics: An Introduction, Fourth edition ed. McGraw-Hill/Irwin, New York, NY.

Goodstein, E.S., 2011. Economics and the Environment, Six edition ed. John Wiley \& Sons, Inc., Hoboken, NJ.

Goulder, L.H., Parry, I.W.H., 2008. Instrument Choice in Environmental Policy, Review of Environmental Economics and Policy 2, 152-174.

Harrington, W., Morgenstern, R.D., 2004. Economic incentives versus command and control. What's the best approach for solving environmental problems? Resources 152, 13-17.

Havens, K., Gawlik, D., 2005. Lake Okeechobee conceptual ecological model, Wetlands 25, 908-925.

Hiscock, J., Thourot, C., Zhang, J., 2003. Phosphorus budget - land use relationships for the northern Lake Okeechobee watershed, Florida, Ecol. Eng. 21, 63-74.

Mariola, M.J., 2009. Are markets the solution to water pollution? A sociological investigation of water quality trading, Doctoral dissertation, The Ohio State University, Columbus, $\mathrm{OH}$.

Newburn, D.A., Woodward, R.T., 2012. An ex post evaluation of Ohio’s Great Miami water quality trading program, J. Am. Water Resour. Assoc. 48, 156-169.

Newell, R., Stavins, R., 2003. Cost heterogeneity and the potential savings from market-based policies, Journal of Regulatory Economics 23, 43-59. 
Ouyang, W., Wang, X., Hao, F., Srinivasan, R., 2009. Temporal-spatial dynamics of vegetation variation on non-point source nutrient pollution, Ecological Modelling 220, 2702-2713.

Paerl, H.W., Hall, N.S., Calandrino, E.S., 2011. Controlling harmful cyanobacterial blooms in a world experiencing anthropogenic and climatic-induced change, Sci. Total Environ. 409, 1739-1741.

Paerl, H.W., Huisman, J., 2008. Climate. Blooms like it hot, Science 320, 57-58.

Selman, M., Greenhalgh, S., Branosky, E., Jones, C., Guiling, J., 2009. Water quality trading programs: An international overview, World Resources Institute, Washington, DC.

Sharfstein, B., Zhang, J., Bertolotti, L., 2015. Chapter 8: Lake Okeechobee watershed protection program annual update, South Florida Environmental Report, South Florida Water Management District, West Palm Beach, FL.

Shortle, J.S., 2013. Economics and environmental markets: Lessons from waterquality trading, Agricultural and Resource Economics Review 42, 57-74.

Stavins, R.N., Whitehead, B.W., 1996. The next generation of market-based environmental policies, Resources for the Future, Washington, DC.

USEPA, 2009. National water quality inventory: Report to Congress - 2004 reporting cycle, EPA 841-R-08-001, U.S. Environmental Protection Agency, Washington, DC.

USEPA, 2003. Water quality trading assessment handbook: EPA region 10's guide to analyzing your watershed, EPA 910-B-03-003, U.S. Environmental Protection Agency, Washington, DC.

Zhang, H., Huang, G.H., 2011. Assessment of non-point source pollution using a spatial multicriteria analysis approach, Ecol. Model. 222, 313-321. 


\section{CHAPTER 2}

\section{WATER QUALITY TRADING PROGRAMS TOWARDS SOLVING ENVIRONMENTAL POLLUTION PROBLEMS}

Corrales J, Naja GM, Rivero RG, Miralles-Wilhelm F, Bhat MG. 2013. Water quality trading programs towards solving environmental pollution problems. Irrigation and Drainage 62 (Suppl. 2): 72-92.

\subsection{Abstract}

Increased regulatory attention in controlling pollutants has encouraged the development of water quality trading programs for the past several decades. These trading programs could provide the mechanisms to cost-effectively achieve water quality objectives. Encouragement of innovative methodologies for emission prevention and control, and the contributions from non-regulated pollution sources are also important factors in the development of successful water quality trading programs. The objectives of this paper are to: assess the advantages of a trading program to reach water quality goals while providing additional benefits to the whole watershed; describe the challenges confronted during the design to implementation phases; and outline the essential elements of a successful program. A meta-analysis was also conducted using several water quality trading programs to assess main market-based elements driving the success of trading programs between point and agricultural nonpoint sources. Uncertainty, policy drivers and social embeddedness the degree to which stakeholders are integrated into the program development - seem to be the most influential determinant of the program success. 


\subsection{Introduction}

Interest in environmental trading programs has been increasing for several decades. The Hunter River Salinity Trading Scheme (Australia), South Nation Phosphorus Trading Program (Canada) and Lake Taupo Nitrogen Trading Program (New Zealand) are some examples of trading programs already implemented or under development around the world (Selman et al., 2009). In the United States (USA), trading programs have been developed promoting economic and environmental advantages (e.g., Breetz et al., 2004). The history of these environmental programs can be traced back to the 1980s where inter-refinery trading was used to address lead in gasoline (Kerr and Newell, 2003). Other environmental issues have been managed through trading programs, such as acid rain, wetland mitigation, endangered species habitat, stream bank restoration, greenhouse gas reduction, and most recent in the water quality arena (Boyner, 2004; Burtraw and Palmer, 2004; Shabman and Stephenson, 2004).

In theory, trading programs allow one polluting source to meet its regulatory obligations by purchasing pollution reductions achieved by another source with lower abatement costs. The latter, in turn, obtains revenue for their efforts in reducing pollution (US Environmental Protection Agency (USEPA), 2007c). Generally speaking, the sources with lower abatement costs are the nonpoint sources unregulated under the Clean Water Act (CWA). In practice, because trading programs are site specific, such as in the water quality case, trading policies and rules must be applicable to suit the specific conditions of the watershed (Lal et al., 2009). For this reason, trading programs design, objectives and success vary widely. Promoters of trading have been using different names to define this type of program such as cap and trade, effluent trading, and pollutant exchange just to name a few. Regardless of 
its name, the objective of any environmental trading program is to provide a costeffective mechanism and decision making flexibility to achieve an environmental goal (Horan et al., 2002a; Shabman and Stephenson, 2007; Hamstead and BenDor, 2010; Stephenson et al., 2010). In addition, water quality trading programs offer a policy mechanism to engage nonpoint sources, i.e., pollution sources not regulated under the federal regulatory extent of the CWA.

In water quality programs, US regulatory agencies have been leading the efforts implementing trading systems to control effluents and achieve water quality standards (Stephenson et al., 1998). Most of these efforts have been devoted to developing trading policies and guidelines for different pollutants, such as nitrogen, phosphorus, sediments, temperature and biological oxygen demand (USEPA, 2004; Lal et al., 2009) focusing on the contaminant of concern in the watershed, impacting a specific waterbody. The U.S. Environmental Protection Agency (USEPA) has encouraged the trading program concept while financing several feasibility studies and demonstration efforts and issuing a water quality trading policy guide, a handbook and a toolkit for permit writers (USEPA, 2003, 2004, 2007a). The United States Department of Agriculture (USDA) has also promoted water quality trading while releasing a new policy for environmental management with the aim of expanding the use of market mechanisms (USDA, 2006) and also targeting several aspects of point and nonpoint trading mechanisms (Letson, 1992; Malik et al., 1993; Crutchfield et al., 1994).

Trading programs in the US have emerged in different watersheds to solve water quality problems associated especially with excessive nutrient levels (Virginia Department of Environmental Quality (VDEQ), 2008; Connecticut Department of Environmental Protection (CTDEP), 2010a; Hamstead and BenDor, 2010). However, even with several success stories, some authors remain skeptical and consider that the 
majority of these trading programs lack market-based fundamentals (Stephenson et al., 1998; Collentine, 2006; Shabman and Stephenson, 2007), which would provide more equitable, efficient, and cost-effective ways to address water quality problems (Chesapeake Bay Program Nutrient Trading Negotiation Team (CPNT), 2001). On the other hand, other trading program experts have demonstrated that it is possible to design a program endorsing the potential benefits of a market-based system within the existing regulatory structure (Boyd et al., 2003; Swift, 2005).

The objectives of this paper are to: review the potentials of a trading program implemented to reach water quality goals; describe the challenges confronted during the design to implementation phases; define the essential elements of a successful program; and illustrate some examples of water quality trading programs to provide insight into the development of a trading program in a specific watershed. Finally, a meta-analysis was also conducted to rank the main elements driving the success of a trading program.

\subsection{Advantages of a Water Quality Trading Approach}

The benefits of a trading program have been well acknowledged by economists, policy makers and environmental groups in many reports and research papers (Boyd et al., 2003; USEPA, 2003; Swift, 2005). The main advantage of trading programs in comparison with the traditional command-and-control approaches is that trading allows flexibility on whom and where pollution control measures are implemented without prescribing how to achieve the reduction, thus creating incentives to innovate within the pollution reduction scope (Borisova and Roka, 2009). Other advantages cover a range of environmental, economic and social improvements in the specific 
watershed where the trading program is implemented. Table 2-1 summarizes the most significant potential benefits of a water quality trading program.

\section{Environmental benefits}

From the environmental perspective, water quality trading programs advantages are mainly focused on attainment of water quality standards, improved compliance levels, and pollution prevention (Shabman and Stephenson, 2007). The attainment of water quality targets is done through setting a mandatory watershed goal, commonly known as a cap. This cap is the total pollutant amount allowed to be discharged from a specific watershed. Under the CWA structure, the cap is often referred to as the Total Maximum Daily Load (TMDL), which is the maximum amount of pollutant that a water body can receive and still meet its designated use (Borisova and Roka, 2009). The cap is then distributed among sources by allocating permissions (or allowances) to discharge a certain amount of pollutant in a limited time. In a market-based trading program, the sources facing high pollution control costs (i.e. point sources) will meet their allowances by purchasing environmentally equivalent pollution reductions from other sources at a lower cost. Thus, trading has the potential to accomplish the same or better overall water quality improvement in a watershed (USEPA, 2007a), and reduce the cost of achieving pollution reductions mandated under the Clean Water Act. Generally, nonpoint sources are achieving pollution loading reductions through the implementation of Best Management Practices (BMP) monitored for efficiency, process to be evaluated and approved by the regulatory authorities. Broader and indirect potential environmental benefits could also be offered when implementing water quality trading programs and reaching water quality standards (Swift, 2005). Some of these additional benefits include improved wildlife habitat, endangered species protection, erosion reduction, co-control of pollutants, flood retention, and 
potential restoration of wetlands (Hall and Biorn-Hansen, 2005). For instance, the Rahr Malting project (Minnesota, USA) have reduced sedimentation and improved soil conservation (USEPA, 2008). However, in general, the overriding focus on the accomplishment of water quality standards overshadows the value and attainment of ancillary environmental benefits.

\section{Economic benefits}

Economically, a water quality trading program's major benefit is to reduce the individual pollution abatement cost and to decrease the aggregate cost of achieving water quality goals in the watershed (Florida Department of Environmental Protection (FDEP), 2010a). Generally, agricultural nonpoint sources incur lower abatement costs than point sources (Newburn and Woodward, 2012), and therefore, any trading between these sources leads to an overall cost reduction. For instance, for the Great Miami River Pilot program (Ohio, USA), USEPA (2008) estimated the unit cost for treatment plant upgrades around US\$ 23 per pound of phosphorus removed, whereas the unit cost for BMPs on farms were about US\$ 1.08 per pound removed. The opportunity to trade allowances and to adopt the best pollution control technology based on specific conditions, are the means of creating financial incentives for this pollution prevention program (Stephenson and Shabman, 2010). These incentives apply to the sources seeking pollution reductions and those who are offering them: low-abatement cost sources are stimulated by the revenues from selling the credits accrued when reaching load reductions above their allocations, while high pollution reduction cost sources benefit from implementing low-cost alternatives. As a result, trading programs can provide an innovation mechanism to adopt - and even fund new methodologies for emissions prevention and control. This additional benefit 
creates a market demand for innovative technologies to reduce the pollution levels to even below the requirements (USEPA, 2004).

Social benefits

Trading programs also allow integrating economic and environmental advantages with social benefits to a greater extent than traditional programs. It encourages communication among point and nonpoint sources, regulatory agencies, the public and other stakeholders to promote concerted solutions for a watershed with multiples sources of pollution (USEPA, 1996; FDEP, 2010a). Exhaustive communication among all trading participants including those who oversee the program could reduce initial perceptions of risk and lack of equity, therefore enhancing the initial willingness to discuss trading. Effective partnerships transcend conventional barriers to sustain watershed management by establishing common goals, encouraging natural resources stewardship, with economic mechanisms to achieve environmental improvement. Furthermore, trading can offer the possibility for new and expanding sources to purchase credits from existing sources, thus accounting for population growth and water quality requirements (CPNT, 2001). One of the main benefits of water quality trading programs is to achieve and maintain water quality goals with population and economic growth.

\subsection{Challenges Associated With Water Quality Trading Programs}

Several limitations could hamper the practical and successful implementation of the water quality trading concept, and also increase the risk that trading will not be able to accomplish environmental quality goals. These challenges, summarized in Table 2-2, can be grouped in three main categories: 1) regulatory, 2) uncertainty, and 3) economic barriers. The fourth program design category involving the credit supply 
and demand, the cost / price dynamics to support a market as well the geographic restrictions was not discussed here but was mentioned in the Table for completeness. Regulatory

The existing statutory and regulation constraints can limit the flexibility in the credit exchange, a fundamental market-based principle of a trading program. Through the issuance of individual National Pollutant Discharge Elimination System (NPDES) permits, the current regulatory structure of the CWA grants legal permission to discharge polluted water only to point sources (USEPA, 2007b). These point sources, such as industrial and municipal wastewater treatment plants, discharge effluents into water bodies at an identifiable location (Ribaudo and Gottlieb, 2011). However, in the case of a nutrient trading program, nonpoint sources discharging over a diffuse area, such as agricultural operations, do not have legal liabilities to control nutrient discharges (Shabman and Stephenson, 2007). Yet, nonpoint sources are well known to dominate the total nutrient loadings in the majority of watersheds (USEPA, 2000) and also to offer, under most circumstances, lower nutrient reduction costs (Ribaudo et al., 2005). Although nutrient abatement costs are site specific and technology dependent, if a trading program fails to incorporate point and nonpoint sources of pollution, the cost savings and compliance itself could be compromised. In addition, the credit exchange flexibility could be threatened by covering just one category of pollution sources.

There are practical ways of efficiently incorporating market-based characteristics into a trading program design within the existing regulatory structure. One approach already implemented is to perform trading under a group compliance permit (USEPA, 2007b) whereby association members can choose and implement their own initiatives for pollution control with more credit exchange flexibility. In addition, under the 
group compliance scheme, the role of regulatory agencies is shifted from imposing technologies to achieve effluent reduction to requiring monitoring and measurement of discharged pollutants. This approach has been effectively implemented in the Neuse River program (North Carolina, USA) where nitrogen loadings to estuaries have diminished by $70 \%$ since 1995, and savings have been observed when the group permit association handled water quality monitoring (Neuse River Compliance Association (NRCA), 2011). The group permit option for the Neuse River program consisted of setting a collective cap for total nitrogen based on the sum of association members' individual nitrogen allocations. In this program, point and nonpoint trading occur indirectly through the North Carolina Wetland Restoration Fund. There are no individual penalties as long as the group as a whole is in compliance. Only when the group of regulated sources exceeds the cap, the group is then subject to a penalty that must be paid to the Fund, that secures that the payments collected result in nonpoint source nitrogen reductions (Breetz et al., 2004; Hamstead and BenDor, 2010). Although, the Neuse River program diverges from the standard permit with which regulatory agencies are familiar, it demonstrates that there is a way to facilitate a workable permitting approach for water quality trading programs (USEPA, 2008).

A lack of consistent support in resources allocated to trading programs from environmental agencies at the federal and state levels is another institutional obstacle. While the federal government is encouraging trading program implementation, the position of regional environmental agencies, particularly among permit writer with preconceived notions of trading, is sceptical to explore new alternatives that stray from the conventional approach. It is only when compliance targets are not reached through the conventional rule making approach, that a trading program is explored as an alternative. While evaluating water quality trading programs, USEPA (2008) 
reported that the lack of consistent support allocated to trading programs is a primary barrier hindering their growth. Overcoming this culture is a constant battle that may slow down the funding and implementation of water quality trading programs (USEPA, 2008). One of the reasons for this scepticism could be that the federal and regional agencies may not have invested enough time and resources into educating and persuading the polluting entities on the long-term economic benefits of trading.

\section{Uncertainty and hotspots}

Some sceptics of water quality trading assume that trading can lead to the creation of localized areas with high pollution levels (named 'pollution hotspots') within a watershed (Swift, 2005). These hotspots result when water quality equivalence has not been carefully taken into account in the program design. Water quality equivalence can be addressed by determining appropriate equivalency factors or trading ratios (USEPA, 2008). In order to develop these trading ratios, several factors, such as the geographic and hydrologic complexity of the watershed, the properties of the pollutant (e.g., different phosphorus forms can lead to different eutrophication potentials), and scientific data (whenever available) need to be considered (Kerr and Newell, 2003). Generally, a trading ratio means that more or less than one unit of nonpoint source discharge reduction is required to offset one unit of point source discharge (Borisova and Roka, 2009; Ribaudo and Gottlieb, 2011). Trading ratios are also generally used to account for the pollutant assimilation in the watershed (delivery ratio), for a polluting source impact on sensitive areas (water quality ratio), and to accommodate the uncertainty of the loading reduction efficiency (uncertainty ratio) particularly when nonpoint sources are participating in the program (Whitehead, 2006). Moreover, some programs include an additional retirement ratio to provide a margin of safety for the overall trading program (CPNT, 2001). However, while these 
ratios might be desirable, high trading ratios could become a disincentive for nonpoint source involvement by reducing the economic attractiveness of these trading programs.

Moreover, additional uncertainties emerge when nonpoint sources are involved in a trading program. Some authors argue that the physical characteristics of nonpoint sources and their reliance on random weather events hinder the pollution loading measurement at a reasonable cost (Malik et al., 1993; Shortle and Abler, 1997; Horan et al., 2002b). The quantification challenge of nonpoint sources loadings can be resolved using direct (quantification of flow and pollutant concentration) or indirect measurement tools. Indirect estimation of the effluent reduction effectiveness of different management practices is based on simulation models or results from other studies (Lal et al., 2009). The Pennsylvania's Chesapeake Bay Water Quality Trading program (Pennsylvania, USA) is one of the best examples dealing with the nonpoint source loading uncertainty. A scientifically sound analysis assessing BMPs efficiency values, adjusted to account for uncertainties, was implemented and incorporated into the Bay watershed model (as long-term averages) (Simpson and Weammert, 2008). This reduced the need for uncertainties ratios when trading involved nonpoint sources, while maintaining the delivery, reserve and edge of segment ratios, (Pennsylvania Department of Environmental Protection (PADEP), 2009).

\section{Economic barriers}

The costs associated with the measurement and monitoring of actual nonpoint sources loads are also identified as economic barriers in water quality trading programs (Breetz et al., 2004). These costs can curtail the expected savings in meeting water quality goals. Although direct measurement of nonpoint source discharges could be very expensive, current technologies provide less costly 
alternatives to estimate effluent load reduction. For example, computer models, such as the Watershed Assessment Model (WAM), Soil and Water Assessment Tool (SWAT), and the Agricultural Policy/Environmental Extender (APEX) model (Soil and Water Engineering Technology, Inc. (SWET), 2010; APEX, 2011; SWAT, 2011), calculate site-specific effluent loads based on land use, soil type, topography, and weather conditions. These simulation models are relatively simple to use, reliable, and offer the possibility to simulate several scenarios before any control measure is actually implemented (Arnold et al., 1998; Gassman et al., 2010; Chebud et al., 2011). However, it is important to be aware of the limitations, assumptions, and degree of uncertainty of these computer tools. Site-specific measurements and monitoring of nonpoint source loads should be conducted whenever possible to validate simulation results.

Online market tools have also been developed for several water quality trading programs to estimate the amount of credits generated based on the adopted control practices (Hennessy, 2001). For instance, in the Chesapeake Bay, the World Resource Institute (WRI) in conjunction with environmental agencies have designed a sitespecific online trading platform called NutrientNet (World Resources Institute (WRI), 2007). This tool is used to estimate the nutrient reductions achieved when implementing a certain type of mitigation practices, to post credit offers, and to provide a simple communicating platform among buyers and sellers. Another example of an online tool is the Nitrogen Tracking Tool (NTrT), an enhanced version of the Nitrogen Trading Tool (NTT) originally developed by the Natural Resources Conservation Service (NRCS) in cooperation with the Agricultural Research Service and the USEPA. The NTrT estimates nitrogen, phosphorus and sediment reductions and losses from fields managed under a variety of cropping patterns and management 
practices. This tool helps farmers and other users to estimate the potential number of nitrogen and phosphorus credits to be generated and eventually sold in a water quality trading program, when a specific control program is implemented (Gross et al., 2008; Saleh et al., 2011). These simulation tools along with scientific research on nonpoint source loadings and BMP efficiencies might reduce the uncertainty ratios, therefore decreasing the cost of nonpoint source credits and making them more attractive to point sources (Ribaudo and Gottlieb, 2011).

Another economic barrier is related to the high transaction costs associated with research, negotiations, monitoring and enforcement, and finding trading partners (Stavins, 2003). The real challenge with transaction costs is to retain the cost effectiveness while still meeting environmental efficacy (Woodward et al., 2002). Given that nonpoint sources are generally widely spread throughout watersheds and each farmer would be able to generate few credits, point sources would encounter high transaction costs while searching for trading partners to comply with their requirements and thus hold back trading with nonpoint sources (Ribaudo and Gottlieb, 2011). Likewise, nonpoint sources may face high transaction costs when trying to identify sources interested to buy their credits. Nevertheless, a number of trading programs have implemented market configuration features such as clearinghouses and third-party aggregators to reduce the transaction costs (Breetz et al., 2004). These third-party aggregators are brokers between buyers and sellers, purchasing credits from sellers and then re-selling the credits to willing buyers. Having third-party aggregators in a trading program can minimize the transaction costs while also reducing the uncertainty issue associated to nonpoint sources performance by holding a portion of the purchased credits and taking the risk if a nonpoint source control practice fails to generate the expected credits (Ribaudo and Gottlieb, 2011). Figure 2- 
1 summarizes the key challenges and benefits of water quality programs, as well as some of the suggested solutions discussed above.

\subsection{Elements of a Water Quality Trading Program}

Water quality trading programs may have different designs reflecting the water quality goals and the physical characteristics of each watershed (Borisova and Roka, 2009). Nevertheless, there are some common elements to be implemented pre and post trading (summarized in Figure 2-2) that can be assembled differently to tailor each program needs. Table 2-3 presents a brief description of some trading programs and elements of the corresponding policies. Although many of these trading programs share common features, this paper details only some representative trading policies providing different design and implementation options. All of these trading programs are located in the United States and in Canada (Figure 2-3) with the exception of the Hunter River Trading Scheme located in Australia (not shown on the map).

\section{Tradable commodity}

For a trading system to work, the tradable commodity needs to be expressed in a common unit of measurement for a specific pollutant form (typically kilograms per day or year) in order to quantify and track effluent reductions and enforce discharge limits (Swift, 2005). Careful attention needs to be given to the chemical form of the traded pollutant since different pollutants have different chemical characteristics and their interaction and impact on the water body of concern may differ (USEPA, 1996). In addition, the certification, verification, and enforcement conditions of the tradable commodity are to be determined during the designing phase of the trading program.

Many worldwide water quality trading programs are focused on phosphorus and/or nitrogen, although inclusion of different pollutants, such as sediment and 
salinity into water quality trading policies has been growing. For instance, Pennsylvania's Chesapeake Bay Water Quality Trading program addresses pollution reductions for nitrogen, phosphorus and sediment to meet water quality standards in the Bay and tidal rivers (USEPA, 2010); and the Hunter River Trading Scheme in Australia, provides a mechanism where point sources trade salinity credits in order to reduce and maintain salinity levels in the river (Department of Environment, Climate Change and Water (DECCW), 2009).

Types of trading, eligibility, and baseline

In addition to addressing different pollutants, these programs illustrate different types of trading as well. Most programs allow only one type of trading, either between point sources or between nonpoint sources, the former being the most prevalent type. However, there are programs (e.g. Neuse River and Great Miami River) allowing trading between point and nonpoint sources, such as trading between agriculture landowners and wastewater treatment plants, and other programs (e.g. Lower St. Johns River pilot program located in Florida, USA) permitting trading between urban stormwater and waste treatment facilities.

An important element to consider in any trading program is the determination of trading eligibility. Since a successful program requires an adequate level of credit supply and demand (USEPA, 2004), a preliminary assessment of the type and number of sources located across the watershed needs to be performed. This preliminary assessment of the market's potential while identifying potential sources that may participate in a trading program include: 1) characterization of effluent loadings, 2) proximity to the receiving water body, 3) whether or not they already have pollutant limit requirements, 4) their pollution reduction cost and, 5) their willingness to participate in the program (Obropta and Rusciano, 2006). A substantial difference of 
pollution abatement costs among sources within a watershed is another key factor to be considered (Collentine, 2006; FDEP, 2010a). This will provide financial incentives for sellers, to have an additional revenue stream while generating and selling credits in the market, and for buyers to save on pollution control costs while purchasing credits from the market (Borisova and Roka, 2009).

The concept of baseline arises when nonpoint sources are involved in a trading program. A baseline is the level of performance against which changes create credits for sale in a market; this means that a seller needs to reduce below its baseline to be able to generate credits (Ribaudo and Gottlieb, 2011). Baseline determination differs among water quality trading programs and can be set based either on loads recorded during a specific period, (Hamstead and BenDor, 2010), or on load reduction through a TMDL (Borisova and Roka, 2009), or on agriculture pollution control practices implemented before trading (Ribaudo et al., 2005). As an example, the baseline for nitrogen in the Neuse River Basin program was set based on the 1991-1995 annual average nitrogen loadings.

\section{Goal and allowances}

The goal refers to the total permissible amount of a pollutant allowed to be discharged into a water body in a given period of time. Generally defined as the cap, it is the leading driver that propels pollution sources to seek effluent reductions. Usually a TMDL or a water quality-based requirement in a NPDES permit are the legal mechanisms establishing target conditions in a water quality trading program (FDEP, 2010b). Scientific research provides estimates of the total amount of a pollutant that can be discharged into a specific watershed, while still meeting its designated uses. After the cap is set, discharge allowances are determined for pollutant sources across the watershed. These allowances will establish the baseline for individual sources to 
generate credits to trade (Shabman and Stephenson, 2007). Generally, while the allocations to point sources are reflected in a binding requirement in the NPDES permit, no emission restriction are imposed on nonpoint sources by federal law (USEPA, 2004).

\section{Policy and regulation}

There are also some differences in the policy driver that motivates pollution sources to seek credits to comply with their pollutant limit requirements. Among the programs presented in Table 2-3, the primary water quality driver was the adoption of a TMDL and more stringent discharge limits in the NPDES permits (e.g. Long Island Sound or Lower St. Johns River trading programs). Other programs defined their reduction targets through a general permit providing flexibility in pollution control measures and not forcing point sources to comply with their individual NPDES permits, as long as the group cap is met (e.g. Neuse River Basin trading program). However, in this case, if the collective cap is exceeded, the group is penalized with a fee to secure equivalent load reductions from sources not covered under the group permit (Stephenson and Shabman, 2010).

International water quality trading drivers were based on different guidelines. For example, the Provincial Ministry of Environment (MOE) in Canada required zero phosphorus discharge for new or expanded facilities (O'Grady, 2006). In the case of the Hunter River Salinity Scheme in Australia, established to limit salinity discharges from major point sources, the total allowable salt discharge depends on the river flow and its capacity to assimilate saline discharges (Ferguson, 2005).

\section{Trading ratios}

Generally, water quality trading programs rely on trading ratios to account for uncertainties and to achieve equivalency among the traded credits, particularly when 
nonpoint sources are participating in the program (USEPA, 2008). The most common trading ratios are the delivery, uncertainty, water quality, retirement, and reserve ratios.

The delivery (or location) ratio is set to account for pollutant attenuation throughout a watershed before reaching the impaired water body. This ratio can be applied to point and nonpoint sources while considering their location and distance from the impaired water body. Generally, the greater the distance the pollutant has to travel, the greater the pollutant attenuation will be (CPNT, 2001). Therefore, by implementing this delivery trading ratio, trading between sources at different locations does not infringe on the overall watershed cap (Borisova and Roka, 2009).

The uncertainty ratio is set to account for seasonal loading variability and for the uncertainties related to nonpoint source control practices efficiencies. It is set to compensate for the lack of scientific measurement of nonpoint sources loadings and BMP reduction efficiencies. The most commonly adopted ratio is $2: 1$, set based on BMPs reduction potentials rather than on measured values. Other studies are reporting that lower trading ratios (less than 1:1) should be used particularly when nonpoint sources BMPs reduction uncertainty is greater than point sources control mechanisms uncertainty (Horan and Shortle, 2005).

A water quality ratio may be used to require additional reductions and ensure more progress toward the attainment of water quality goals (CPNT, 2001). This ratio is also set to account for situations when sensitive areas such as wetlands or lakes may require additional water quality considerations. Generally, a percentage of the available credits is retained to reflect the pollution source location relative to sensitive areas. 
The retirement ratio provides a safety margin for the overall trading program. A percentage of all credits generated may be discounted or retired before any trades are negotiated to enhance the potential water quality benefits of the program. These ratios cannot be sold to offset new loads (Selman et al., 2009).

The reserve ratio requires a portion of the total credits generated to be reserved to provide insurance for failed pollution reduction practices. These credits are placed in a reserve fund to be drawn from when purchased credits default. This ratio adds another level of protection to the credits but does not account for the nonpoint sources reduction efficiency uncertainty (PADEP, 2009; Selman et al., 2009).

Most of the water quality trading programs include trading ratios such as in Long Island Sound where a delivery trading ratio of 1.0 was given to the zones with the greatest impact on the dissolved oxygen levels and a ratio of 0.14 was given to areas with less influence on the hypoxia zone (CTDEP, 2010a). In other words, if the seller is located in a trading ratio zone of 1 and the buyer is in a trading ratio zone of 0.14 , the delivery trading ratio is 1:0.14. This means that the seller would need to remove 1 unit of nitrogen in order to compensate 0.14 units of nitrogen generated by the buyer. A ratio combining the attenuation and uncertainty factors could also be used as in the case of the South Nation River where the MOE requires a 4:1 ratio, meaning that $4 \mathrm{~kg}$ of phosphorus must be removed by nonpoint sources for every $1 \mathrm{~kg}$ of phosphorus discharged from point sources (O'Grady, 2011). Different ratios could also be used as in the case of the Pennsylvania Water Quality Trading Program containing three different types of ratios: delivery, reserve, and edge-of-segment (EOS) (Branosky et al., 2011). 


\section{Market structure and credit price}

The market structure specifies trading conditions and covers all guidelines and rules needed for a successful and transparent trading program (Stephenson and Shabman, 1997). Generally, trading markets fall in four main categories: 1) clearinghouses, 2) bilateral negotiations, 3) exchange markets, and 4) sole source offset (USEPA, 2008).

The most common market structure used to support the trading program is the clearinghouse market, where there is an intermediary between the credits seller and buyer (Woodward et al., 2002). The Neuse River and the Great Miami River programs used a clearinghouse entity to translate nutrient credits with variable prices into a uniform commodity, thus reducing transaction costs and mitigating the buyer risk for potential pollution reduction failure (Selman et al., 2009). The Neuse River trading program uses an association of the dischargers to coordinate the trade activity. In the case of the Great Miami River program, the Miami Conservancy District (MCD) serves as a third party broker acquiring credits through contractual agreements with entities subsidizing agricultural producers applying specific BMPs (such as conservation tillage, rotation, pasture seeding/prescribed grazing, etc.) and selling voluntary pollution reduction to regulated sources under a different contractual agreement (Breetz et al., 2004; Bacon and Dupuis, 2011; Newburn and Woodward, 2012). Bilateral trading is another common market structure where there is direct contact between trading partners to exchange information and bargain the terms of the trade, with a public authority participating to approve the negotiation and set suitable trading ratios (USEPA, 2008). In this case, the credit price is reached through a negotiation process, and not by simply checking or noticing an existing credit price on the market (Woodward et al., 2002). This bilateral structure increases transaction 
costs and also the contractual links between trading partners. Exchange markets are less common given the high initial cost incurred to establish the infrastructure allowing the exchange of information, communication and transactions between buyers and sellers. Online marketplaces, such as NutrientNet used in the Pennsylvania trading program, have been successful for tracking credits, providing transparency, monitoring trading activities, and facilitating market participants to find each other (Hennessy, 2001; WRI, 2007; Selman et al., 2009). In the Hunter River program, a biannual auction is conducted whereby the New South Wales Environmental Protection Agency (NSW EPA) auctions 200 new salinity credits every two years, with a 10 year life-span, regardless of whether they are sold at the auction or retained by the Department of Environment, Climate Change and Water (DECCW). This auction process allows equal participation and potential access to the credits for all bidders including new participants to the market (stakeholders, environmental agencies, etc.) (DECCW, 2009). While the auctions occur every two years, the program scheme supports bilateral trading at any time (Ferguson, 2005). It is worth noticing that because the program's location in a semi-arid region, the total allowable salt discharge depends on the river flow and its capacity to assimilate saline discharges. For instance, no discharge is allowed during periods of low flow, a limited discharge is permitted during periods of high flow, and an unlimited discharge is allowed during flood periods (Ferguson, 2005). A less common market structure is the sole source offset, which takes place when a source is allowed to offset their pollution loadings either on-site or by taking reduction loading activities off-site. Here, there is not trading involved (Selman et al., 2009).

The range of credit prices is indicated in Table 2-3 and generally depends on several factors (indicated in Figure 2-2) such as the market structure and the trading 
program policy, the transaction and monitoring costs, the construction and operation costs to remove the pollutant, and the cost of implementing BMPs or other remediation technologies. It is noteworthy that the credit price principally depends on the market rules of supply and demand. When the number of point sources buying credits increases, credit prices increase as well.

\section{Accountability and assistance}

Every trading program must have an administrative system that oversees the monitoring and reporting of pollution reductions with enforcement capabilities. Legal liability and responsibility when effluent reductions are not met must be clearly addressed with specific fees and penalties (Woodward et al., 2002). The administrative entity plays a key role in the implementation and management of a trading program. State agencies should also commit to assume additional economic and regulatory responsibilities associated with the trading program (Keplinger et al., 2004; Borisova and Roka, 2009). Trading partners need also to be assisted throughout the trade negotiations. Some of the actions to facilitate the trades include: 1) identification of sellers and buyers, 2) helping potential point and nonpoint sources understand the trading policy, 3) tracking production, use, and durability of credits, and 4) regularly updating information regarding credit availability, prices and interested trading partners (CPNT, 2001).

\section{Stakeholder engagement}

A successful education and outreach program is important in a water quality trading program. Interested parties (e.g., federal, state and local government, local businesses, universities, and interested citizens) need to be involved and engaged during all stages of the trading program. Potential participants are to be identified and encouraged to participate in order to guarantee a viable water quality trading program 
(King and Kuch, 2003). Several studies investigated the essential role of trust and effective communication with local environmental agencies and its impact on increasing trading partner participation (Mariola, 2009). An example of a successful communication program was developed within the Great Miami River program, where longstanding relationships between environmental agents in the watershed and farmers was cited as an important factor to achieve high rates of farmers involvement (Newburn and Woodward, 2012). Moreover, conducted surveys indicated that the nonpoint source initial participation (willingness to understand, discuss and participate) in a trading program is contingent with the degree of trust in program administrators (Breetz et al., 2005).

\subsection{Meta-Analysis of Water Quality Trading Programs}

Several authors attempted to define a trading program success using different approaches (Breetz et al., 2005; Mariola, 2009; Newburn and Woodward, 2012). An economic approach would define success as a function of market efficiency, low transaction costs, and tools for minimizing uncertainty. Another approach would define success as whether or not a program has resulted in the implementation of agricultural BMPs, directly relating success to social relations between market participants (Mariola, 2009). In the first approach, water quality trading programs are analyzed using a set of economic and institutional variables without accounting for the social aspect (stakeholders and farmers participation) of this type of program. The second approach, defining success based on social embeddedness or on the sole implementation of BMPs, would also be missing the basic definition of a market driven approach. 
In this paper, acknowledging the need for an adequate market structure and the importance of social interactions among participants, the success of a trading program involving point and agricultural nonpoint sources was defined as the ease of making trades while taking into account the enhancement of social relationships among participants affecting the willingness to participate. However, it should be noted that even if a trading program was considered here as successful (and had all the components to facilitate trading), polluting sources could decide not to trade. Moreover, attainment of water quality goals was not considered here as a measure of success since, for most of the trading programs herein evaluated, the realized loading reductions could not be explicitly and exclusively linked to the trading program implementation. Furthermore, cost saving was also not considered here as a success measure since a detailed economic analysis was lacking in most of the evaluated trading programs. As an alternative, the structure of water quality trading markets was considered as it plays a key role on how trading partners respond to pursuing achievement of water quality goals and also on the cost effectiveness of the program.

The economic / social definition of success considered here takes into account the economic aspect of trading activities, highlighting the need for an open information structure to facilitate trading. Indeed, the difficulty of creating an effective and smoothly operating market place where trading partners can identify each other (social aspect), find information and engage in negotiations, is the reason for high transaction costs and market stagnancy (Shabman and Stephenson, 2007). In fact, in some cases, even with financial and policy drivers, farmers remain unwilling to participate in water trading activities. Enhancing social relationships is critical for the success of trading programs. Social relationships and networks could be classified as embedded or at arms-length (Uzzi, 1999). Arm's-length ties function without any 
prolonged social contact between parties and do not require any extended communication or social contracts. In embedded ties, information exchanges between actors are dependent on social attachments that produce expectations of trust and reciprocity - important elements of water quality trading programs. These high levels of trust and reciprocity facilitate the sharing of private information (Adali et al., 2012). In a water quality trading program, embedded relationships create a unique value and motivate exchange partners to share the value of their mutual benefits through transfer of private resources and self-enforcing governance (Uzzi, 1997).

Table 2-4 summarizes 10 trading programs involving point and agricultural nonpoint sources. It illustrates a diverse array of approaches to solving watershed water quality problems. Each program was evaluated based on the established structure for searching partners and for bargaining. Programs with an exchange market or a clearinghouse structure were assessed as having a trading framework that simplifies the trading of credits, because of their lower transaction costs, while offering an open information structure (with an enhanced education outreach program) and creating embedded relationships among trading partners facilitating the interactions between buyers and sellers without increasing the transaction costs. Based on this definition of success, and from the 10 cases evaluated here, six were categorized as successful. Some of them are in agreement with results published elsewhere (USEPA, 2008; Mariola, 2009; Newburn and Woodward, 2012). The Rahr Malting Company program was evaluated as not successful because of the heavy market structure - designing a permit and trading framework, negotiations with landowners, writing detailed contracts, and monitoring the implementation of nonpoint source controls - leading to high transaction costs. Breetz et al., (2004) reported that the high administration and transaction cost as the major obstacle for the 
ease of trading for this Rahr Malting Company program. In the case of the Lower St. Johns program, it is up to the seller to find a willing buyer with an individual NPDES permit, thus increasing transaction costs associated with the identification of trading partners. It is important to highlight that this is a relatively new program with only a few formal credit trades, mainly due to the uncertainty about the upcoming new numeric nutrient limits that facilities would have to meet. A lower trading ratio before the implementation of the nutrient limits would have encouraged the trading (following the Great Miami River trading program example).

In order to determine the variables with the strongest effect on the success or failure of water quality trading programs, a meta-data analysis was conducted using the 10 trading programs (Table 2-4). This statistical assessment was based on a binomial correlation methodology used by Mariola (2009) and explained below. This approach was selected because of statistical limitations imposed when having a small number of case studies. Independent and dependent variables were classified into a binomial form, constructing a 'truth table', in which the absence or presence of each independent variable was evaluated based on their contribution to the dependent outcome. This quasi-quantitative approach is provided insights on the correlation between variables and the success of a trading program. The selected independent variables driving our definition of a program success are policy drivers, minimization of uncertainty, flexibility, trading activity, and social embeddedness. It is worth noticing that measures of success selected by Mariola (2009) were policy drivers, trading ratio $<2: 1$ (a tool for minimizing uncertainty), market freedom or flexibility and social embeddedness while assessing a trading program success between point and nonpoint agricultural sources. The measures of success selected in this paper to 
conduct the meta-analysis were similar to those used by Mariola (2009) but the variables were differently defined as detailed below.

Table 2-4 presents the five independent variables matched with the 10 selected water quality trading programs. Each program was labelled with a $(+)$ or $(-)$ score based on how they influence the easiness of trading. The final row of the table lists the binomial correlation coefficients (BCC) linking the trading programs and each respective independent variable. These coefficients represent the degree of association between each variable and the success of a trading program as it is defined earlier in this review.

Policy drivers

The policy drivers can be in the form of binding obligations, such as TMDLs, NPDES permits or nutrient criteria, or in the form of incentives (whenever nutrient requirements have not been imposed). Policy drivers are a key element motivating point and nonpoint sources to participate in a trading program, thus affecting the 'willingness to participate', a success factor of the trading programs. In Table 2-4, a program with a policy driver was allocated a (+) score and a program without a policy driver or with an inadequate cap was allocated a negative (-) score. Inadequate caps refer to setting a binding regulation that is either too high or too low. Programs with other drivers different than a policy one, were allocated a '(+/-)' score if the program has resulted in significant demand for pollution reduction credits. An example of a program without a policy driver is the Great Miami River trading program that emerged before stricter state-wide nutrient limits and watershed TMDLs were in place. This program encouraged facilities (under threat of regulation) to purchase phosphorus credits generated through voluntary and less costly nonpoint source reductions (Water Conservation Sub-district of the Miami Conservation District 
(WCS), 2005). Despite the absence of a regulatory obligation, this program has been successful in creating a large credit supply and a high number of agricultural abatement funded projects (Newburn and Woodward, 2012).

\section{Minimization of uncertainty}

The uncertainty associated with nonpoint sources BMPs efficiencies and monitoring is one of the most cited barriers responsible for a limited success of a water quality trading program. This factor is a key element affecting the 'willingness to participate' of sources in a trading program. Therefore, the 10 programs were evaluated based on the methods used to calculate the credits generated by nonpoint sources by implementing a specific management practice. Some trading programs have developed their own tools (NutrientNet for Pennsylvania and STEPL Spreadsheet Tool for Estimating Pollution Loads for the Great Miami River) based on scientifically sound modeling, and others have required monitoring for the verification of load reductions. Programs falling in either case were assigned a $(+)$ score, because they reduce the uncertainty attributed to nonpoint sources, hence increasing the willingness of participation and easiness of trading. The South Nation River program was assigned a (+/-) score (intermediary score) because it relies on published documents to calculate the amount of phosphorus removed by different BMPs (O'Grady, 2011). This method of pre-determined nutrient reductions, regardless of location, is less accurate than site-specific calculations (Selman et al., 2009). The Lower St. Johns program was also assigned a (+/-) score because it does not require the use of any specific and standardized tool for credit calculation, which is currently based on estimates of adjustment factors, to address the uncertainty. 


\section{Flexibility}

Programs offering flexibility (impacting the ease of trading) for pollution sources to implement technologies to control their pollution were allocated a $(+)$ score. For instance, the South Nation River Watershed program was allocated a $(+)$ score because it clearly states that it is up to the discharger to develop and implement the most cost-effective method to reduce phosphorus loadings. In contrast, other programs (assigned a (-) score) are somehow constrained by the already evaluated and available BMPs. However, if the program allows sources to propose new mitigation practices to be considered as eligible activities to generate credits were given a (+/-) score.

\section{Trading activity}

This criterion was evaluated positively if credits were traded during the program duration - a direct indication of the ease of trading. Trades occurring as a result of point source emission offset by implementation of nonpoint BMPs were also considered. A negative evaluation was given to programs, such as the Tar-Pamlico trading program (North Carolina, USA), because by implementing several operational measures and minor capital improvements by point sources, the nutrient reduction goals were reached without the need for credit trading.

\section{Social embeddedness}

This variable evaluated how trading programs alleviate social constraints, such as lack of trust, communication, and participation among stakeholders. Programs with established communication mechanisms (e.g. education and outreach, use of existing relationships, and creation of information sharing channels), were assessed to be socially embedded, with a positive $(+)$ score. Lack of these mechanisms hinders the identification of trading opportunities and makes it more difficult to exchange credits 
and thus increasing the transaction costs. It is important to note that these are communication mechanisms, not programs structures. One positive example is the Miami River Watershed trading program using the Miami Conservancy District (MCD) as a clearinghouse for wastewater treatment plants, participants, and farmers. This program has been able to use a pre-existing network of relationships and institutional infrastructure to disseminate information and recruit participants (Newburn and Woodward, 2012).

The binomial correlation coefficients (BCC) (Table 2-4) revealed that minimization of uncertainty is highly correlated to the trading program success definition $(\mathrm{BCC}=0.85)$. The nonpoint source load reduction estimation using sitemonitoring or modeling techniques is crucial for enhancing participation of point sources. Likewise, the meta-analysis indicated that policy drivers $(\mathrm{BCC}=0.8)$ are correlated to the trading program success definition given that they represent the first motivation for the implementation of and participation in a trading program. Social embeddedness $(\mathrm{BCC}=0.7)$ also showed to be significant for the functionality of a program. Trusted social relationships are needed to reduce concerns of nonpoint sources about impacts of risk and equity on benefits and responsibilities, to decrease transaction costs, and to create a more efficient market.

\subsection{Conclusions}

Increased regulatory interest in controlling pollutants causing the impairment of water bodies has stimulated the growth of water quality trading programs. Advocates of this initiative claim that market-based trading programs provide an additional tool for solving watershed-based water quality problems. Cost effectiveness, decision making flexibility, involvement of non-regulated pollution sources, and technological 
advancements for abatement verification and market transactions are also highlighted as factors contributing to the development of water quality trading programs. Recognizing the benefits, challenges, and key elements associated with these types of programs is the first step for an effective program design. Furthermore, understanding the drivers for the pollution reduction achievement is essential to guarantee sufficient trading activity. The watershed goal and the associated allocations are the foundation of a well structured trading program. A successful trading system carefully assesses conditions such as pollutant suitability, financial attractiveness, feasible market structures, and stakeholder willingness. In addition, the meta-analysis conducted using several water quality trading case studies revealed that minimization of uncertainty, policy drivers, and social embeddedness are the most significant variables influencing the success of a trading program. It is noteworthy that a program success is not solely based on providing economic incentives, nor having a structure that minimizes transaction cost, nor is it solely based on having regulatory drivers. Rather it is an interaction among all these variables, handled properly within each program, that makes a program successful. Although water quality trading programs face regulatory, technical and economic challenges, there are viable approaches to overcome these barriers and effectively implement a water quality trading program. Many of the challenges that emerge during the design and implementation of the program can be solved if innovative thinking is introduced.

\subsection{Acknowledgments}

The authors thank the Bachelor Foundation and the Darden Foundation for their financial support. 


\subsection{References}

Adali S, Sisenda F, Magdon-Ismail M. 2012. Actions speak as loud as words: Predicting relationships from social behavior data. In International World Wide Web Conference Committee (IW3C2) 2012 - Session: Social Interactions and the Web, 16-20 April 2012, Rensselaer Polytechnic Institute, Lyon, France.

APEX. 2011. Agricultural Policy Environmental Extender. Available at http://apex.tamu.edu/.

Arnold JG, Srinivasan R, Muttiah RS, Williams JR. 1998. Large area hydrologic modeling and assessment Part I: Model development. Journal of the American Water Resources Association 34:73-89.

Bacon L, Dupuis T. 2011. Water quality credit trading. Experiences around the country. In Nutrient Trading Training Workshop. 13 April 2011, CH2M Hill, Helena, MT.

Borisova T, Roka F. 2009. Water Quality Credit Trading: General principles. Electronic Data Information Source (EDIS), Gainesville, FL.

Boyd J, Burtraw D, Kripnick AMV, Newell R, Palmer K, Sanchirico J, Walls M. 2003. Trading cases: Five examples of the use of markets in environmental and resource management. In The RFF Reader in Environmental and Resource Policy, Oates WE (ed). Resources for the Future: Washington, D.C. p. 56-65.

Boyner GC. 2004. Carbon markets: Reducing greenhouse gas emissions through emissions trading. Tulane Environmental Law Journal 17:270-297.

Branosky E, Jones CY, Selman M. 2011. Comparison Tables of State Nutrient Trading Programs in the Chesapeake Bay Watershed. World Resources Institute, Washington, D.C.

Breetz HL, Fisher-Vanden K, Garzon L, Jacobs H, Kroetz K, Terry R. 2004. Water Quality Trading and Offset Initiatives in the US: A Comprehensive Survey. Dartmouth College, Hanover, NH.

Breetz HL, Fisher-Vanden K, Jacobs H, Schary C. 2005. Trust and communication: Mechanisms for increasing farmer's participation in water quality trading. Land Economics 81:170-190.

Burtraw D, Palmer K. 2004. $\mathrm{SO}_{2}$ cap-and-trade program in the United States: A living legend of market effectiveness. In Choosing environmental policy, comparing instruments and outcomes in the United States and Europe, Harrington et al., (eds.). Resources for the Future: Washington, D.C. p. 41-66.

Crutchfield SR, Letson D, Malik AS. 1994. Point-Nonpoint trading of agricultural pollutant loadings to coastal waters. Water Resources Research 30:2825-2836. 
Chebud Y, Naja GM, Rivero R. 2011. Phosphorus run-off watershed assessment: from monitoring to modeling through a case study. Journal of Environmental Monitoring 13:66-73.

Collentine D. 2006. Composite market design for a transferable discharge permit (TDP) system. Journal of Environmental Planning Management 49:929-946.

Chesapeake Bay Program Nutrient Trading Negotiation Team (CPNT). 2001. Chesapeake Bay Program Nutrient Trading Fundamental Principles and Guidelines. CBP/TRS 254/01. Annapolis, MD, USA

Connecticut Department of Environmental Protection (CTDEP). 2010a. Connecticut's Nitrogen Credit Exchange - An Incentive-Based Water Quality Trading Program, Bureau of Water Protection and Land Reuse, Hartford, CT, USA.

Connecticut Department of Environmental Protection (CTDEP). 2010b. Report of the Nitrogen Credit Advisory Board for Calendar Year 2009. To the Joint Standing Environment Committee of the General Assembly, Hartford, CT, USA.

Department of Environment, Climate Change and Water (DECCW). 2003. Proposal: Auctioning Hunter River Salinity Trading Scheme Credits. Department of Environmental and Conservation (NSW), Sydney, Australia.

Department of Environment, Climate Change and Water (DECCW). 2009. Hunter River Salinity Trading Scheme Credit Auctions. Department of Environment, Climate Change and Water (NSW), Sydney, Australia.

Earles TA, Lorenz WF, Koger WL, Trujillo MY. 2008. Nonpoint source phosphorus trading in the Cherry Creek Reservoir Watershed in Colorado. Journal of Irrigation and Drainage Engineering 134:589-597.

Ferguson A. 2005. Australia: A Pioneer in Sustainable Emissions Trading. Available at http://www.ecosystemmarketplace.com/pages/dynamic/article.page.php?page _id=2086\&section=home\&eod $=1$.

Florida Department of Environmental Protection (FDEP). 2010a. The Pilot Water Quality Credit Trading Program for the Lower St. Johns River. A Report to the Governor and Legislature, Tallahassee, FL, USA.

Florida Department of Environmental Protection (FDEP). 2010b. Water Quality Credit Trading and the Pollutant Trading Policy Advisory Committee, West Palm Beach, FL, USA.

Gannon R. 2003. Nutrient strategy for the Tar-Pamlico River Basin, North Carolina. In USDA Seminar on Nutrient Trading, 23 October 2003, NC Division of Water Quality.

Gassman PW, Williams JR, Wang X, Saleh A, Osei E. 2010. The agricultural policy environmental extender (APEX) model: An emerging tool for landscape and 
watershed environmental analyses. American Society of Agricultural and Biological Engineers 53:711-740.

Graziani M. 2007. Water quality pollutant trading. In Trading Advisory Committee Meeting, 27 February 2007, Minnesota pollution control agency.

Gross CM, Delgado JA, McKinney SP, Lal H, Cover H, Shaffer M. 2008. Nitrogen trading tool to facilitate water quality credit trading. Journal of Soil Water Conservation 63:44A-45A.

Hall L, Biorn-Hansen S. 2005. Trading to improve water quality. The Environmental Trading Network (Webcast). US Environmental Protection Agency and Oregon Department of Environmental Quality.

Hall D. 2009. Water quality credit trading: Ohio's Great Miami River Watershed. In Water Quality Credit Trading Workshop, 8 July 2009, The Miami Conservancy District. Dayton, OH.

Hamstead ZA, BenDor TK. 2010. Over-compliance in water quality trading programs: Findings from a qualitative case study in North Carolina. Environment and Planning C: Government and Policy 28:1-17.

Hennessy R. 2001. Nutrient trading to improve water quality. Pollution Engineering 33:10-14.

Horan RD, Abler DG, Shortle JS, Carmichael J. 2002a. Cost-effective point-nonpoint trading: An application to the Susquehanna River Basin. Journal of the American Water Resources Association 38:467-477.

Horan RD, Shortle JS, Abler DG. 2002b. Point-nonpoint nutrient trading in the Susquehanna River Basin. Water Resources Research 38:1050-1062.

Horan RD, Shortle JS. 2005. When two wrongs make a right: Second-best pointnonpoint trading ratios. American Journal of Agricultural Economics 87:30-352.

Keplinger KO, Houser JB, Tanter AM, Hauck LM, Beran L. 2004. Cost and affordability of phosphorus removal at small wastewater treatment plants. Small Flows Quarterly 5:36-49.

Kerr S, Newell RG. 2003. Policy induced technology adoption: Evidence from the US lead phase-down. The Journal of Industrial Economics 5:317-343.

Kieser \& Associates. 2004. Preliminary Economic Analysis of Water Quality Trading Opportunities in the Great Miami River Watershed, Ohio, Kalamazoo, MI.

King D, Kuch P. 2003. Will nutrient credit trading ever work? An assessment of supply and demand problems and institutional obstacles. Environmental Law Reporter 33:10352-10368. 
Lal H, Delgado JA, Gross CM, Hesketh E, McKinney SP, Cover H, Shaffer M. 2009. Market based approaches and tools for improving water and air quality. Environmental Science \& Policy 12:1028-1039.

Letson D. 1992. Point/nonpoint source pollution reduction trading: an interpretive survey. Natural Resources Journal 32:219-232.

LSJR TMDL Executive Committee. 2011. For the Lower St. Johns River Main Stem Basin Management Action Plan. Florida Deparment of Environmental Protection, Tallahassee, FL.

Malik AS, Letson D, Crutchfield SR. 1993. Point/nonpoint source trading of pollution abatement: Choosing the right trading ratio. American Journal of Agricultural Economics 75:959-967.

Mariola MJ. 2009. Are markets the solution to water pollution? A sociological investigation of water quality trading. PhD thesis, Ohio State University, Columbus, $\mathrm{OH}$.

Minnesota Pollution Control Agency (MPCA). 1997. NPDES Watershed-Based Permitting Case Study: Rahr Malting Company Point Source-Nonpoint Source Trading., St. Paul, MN, USA.

Neuse River Compliance Association (NRCA). 2011. Letter to the North Carolina Environmental Management Commission, Clayton, NC, USA.

Newburn DA, Woodward RT. 2012. An ex post evaluation of Ohio's Great Miami water quality trading program. Journal of the American Water Resources Association 48:159-169.

O'Grady D. 2006. Total Phosphorus Management Instruments. South Nation Conservation, Ontario, Canada.

O'Grady D. 2011. Sociopolitical conditions for successful water quality trading in the South Nation River watershed, Ontario, Canada. Journal of the American Water Resources Association 47:39-51.

Obropta CC, Rusciano GM. 2006. Addressing total phosphorus impairments with water quality trading. Journal of the American Water Resources Association 42:1297-1306.

Pennsylvania Department of Environmental Protection (PADEP). 2009. Appendix A: Nutrient Trading Criteria Specific for the Chesapeake Bay Watershed. Revisions to the Final Trading of Nutrient and Sediment Reduction Credits-Policy and Guidelines. Pennsylvania Department of Environmental Protection.

Pennsylvania Department of Environmental Protection (PADEP). 2011. Nutrient Trading Program. Contract/Trade Information, Harrisburg, PA. Available at http://www.dep.state.pa.us/river/Nutrient\%20Trading.htm. 
Ribaudo MO, Heimlich R, Peter M. 2005. Nitrogen sources and gulf hypoxia: Potential for environmental credit trading. Ecological Economics 52:159-168.

Ribaudo MO, Gottlieb J. 2011. Point-nonpoint trading - Can it work? Journal of the American Water Resources Association 47:5-14.

Saleh A, Gallego O, Osei E, Lal H, Gross C, McKimmey S, Cover H. 2011. Nutrient tracking tool - a user friendly tool for calculating nutrient reduction for water quality trading. Journal of Soil and Water Conservation 66:400-410.

Selman M, Greenhalgh S, Branosky E, Jones CY, Guiling J. 2009. Water Quality Trading Programs: An International Overview. World Resources Institute, Washington, D.C.

Shabman L, Stephenson K. 2004. Wetlands credit sales as a strategy for achieving no net loss: The limitations of regulatory conditions. Wetlands 18:471-481.

Shabman L, Stephenson K. 2007. Achieving nutrient water quality goals: Bringing market like principles to water quality management. Journal of the American Water Resources Association 43:1076-1089.

Shortle JS, Abler DG. 1997. Nonpoint pollution. In International yearbook of environmental and natural resource economics, Folmer et al., (eds.), Edward Elgar Publishing: Cheltenham, United Kingdom. p. 114-155.

Simpson TW, Weammert SE. 2008. Revising BMP efficiencies for the Chesapeake Bay Watershed. In Proceedings of the $21^{\text {st }}$ Century Watershed Technology: Improving Water Quality and Environment Conference, 29 March - 3 April 2008, American Society of Agricultural and Biological Engineers, Conception, Chile.

Stavins R. 2003. Market-based Environmental Policies: What Can We Learn from U.S Experience (and Related Research)? Resources for the Feature, Washington, D.C.

Stephenson K, Shabman L. 1997. Effluent Allowance Trading: A New Approach to Watershed Management. The Water Science Reporter. National Institutes for Water Resources, Blacksburg, VA.

Stephenson K, Norris P, Shabman L. 1998. Watershed-based effluent trading: The nonpoint source challenge. Contemporary Economic Policy 16:412-421.

Stephenson K, Shabman L. 2010. Rhetoric and reality of water quality trading and the potential for market-like reform. Journal of the American Water Resources Association 47:15-28.

Stephenson K, Aultman S, Metcalfe T, Miller A. 2010. An evaluation of nutrient nonpoint offset trading in Virginia: A role for agricultural nonpoint sources? Water Resources Research 46:W04519. 
SWAT. 2011. Soil and Water Assessment Tool. Available at http://swatmodel.tamu.edu/.

Soil and Water Engineering Technology, Inc. (SWET). 2010. Watershed Assessment Model. Available at http://www.swet.com/wam.htm.

Swift B. 2005. U.S. emissions trading: Myths, realities, and opportunities. Natural Resources \& Environment 20:3-9.

US Department of Agriculture (USDA). 2006. USDA Roles in Market-based Environmental Stewardship. Natural Resources Conservation Service, Washington, D.C., USA

US Environmental Protection Agency (USEPA). 1996. Draft Framework for Watershed-based Trading. EPA 800-R-96-001, Washington D.C., USA

US Environmental Protection Agency (USEPA). 2000. National Water Quality Inventory. EPA 841-R-02-001, Washington, D.C., USA

US Environmental Protection Agency (USEPA). 2003. Final Water Quality Trading Policy, Washington, D.C., USA. Available at http://water.epa.gov/type/ watersheds/trading/finalpolicy2003.cfm.

US Environmental Protection Agency (USEPA). 2004. Water Quality Trading Assessment Handbook. Can Water Quality Trading Advance your Watershed's Goals? EPA 841-B-04-001, Washington, D.C., USA

US Environmental Protection Agency (USEPA). 2007a. Water Quality Trading Toolkit for Permit Writers. EPA 833-R-07-004, Washington, D.C., USA

US Environmental Protection Agency (USEPA). 2007b. Watershed-based National Pollutant Discharge Elimination System (NPDES) Permitting Technical Guidance. EPA 833-B-07-004, Washington, D.C., USA

US Environmental Protection Agency (USEPA). 2007c. Wetlands and Water Quality Trading: Review of Current Science and Economic Practices with Selected Case Studies. EPA-600-R-06-155, Ada, OK, USA.

US Environmental Protection Agency (USEPA). 2008. Water Quality Trading Evaluation. EP-W-04-023, Washington, D.C., USA

US Environmental Protection Agency (USEPA). 2010. Chesapeake Bay Total Maximum Daily Load for Nitrogen, Phosphorus and Sediment, Philadelphia, PA., USA

Uzzi B. 1997. Social structure and competition in interfirm networks: The paradox of embeddedness. Administrative Science Quarterly 42:35-67. 
Uzzi B. 1999. Embeddedness in the making of financial capital: How social relations and networks benefit firms seeking financing. American Sociological Review 64:481-505.

Virginia Department of Environmental Quality (VDEQ). 2008. Virginia's Chesapeake Bay watershed nutrient credit exchange program. In ECOS - Water and Ecosystems Committee, 14 April 2008, Richmond, VA, USA.

Water Environment Research Foundation. (WERF). 2001. Phosphorus Credit Trading in the Cherry Creek Basin: An Innovate Approach to Achieving Water Quality Benefits. 97-IRM-5A.

Water Conservation Sub-district of the Miami Conservation District (WCS). 2005. Great Miami River Watershed Water Quality Credit Trading Program, Operations Manual. Water Conservation Sub-district of the Miami Conservancy District, Dayton, $\mathrm{OH}$.

Whitehead JR. 2006. Assessing the potential for water quality trading in the Bear River watershed. MS thesis, Utah State University, Logan, UA.

Woodward RT, Kaiser RA, Wicks AMB. 2002. The structure and practice of water quality trading markets. Journal of the American Water Resources Association 38:967-979.

World Resources Institute (WRI). 2007. NutrientNet, Online Trading Marketplace.. Available at http://www.nutrientnet.org/. 


\subsection{Tables}

Table 2-1. Advantages of water quality trading programs.

\begin{tabular}{ll}
\hline Cost-effective approach to attain water quality standards \\
Environmental & $\begin{array}{l}\text { Improved compliance levels } \\
\text { Implementation of innovative technologies to reduce water pollution levels } \\
\text { below the requirements } \\
\text { Ancillary and indirect ecological benefits }\end{array}$ \\
\hline Economic & Reduced individual pollution abatement cost \\
& Financial incentives and flexibility on how to control effluent reductions \\
& Market demand for new innovative technologies \\
& Funding for new methodologies for emission prevention and control \\
\hline Social & Encourage communication among trading partners, regulatory agencies, public \\
& $\begin{array}{l}\text { and other stakeholders } \\
\text { Shared responsibility and commitment for water quality pollution control }\end{array}$ \\
& Population growth considered while achieving water quality objectives
\end{tabular}

Table 2-2. Challenges of water quality trading programs.

\begin{tabular}{ll}
\hline & Lack of regulatory liabilities for nonpoint sources \\
& Lack of education and awareness among regulated communities \\
Regulatory & Limited support from federal and state environmental agencies \\
& A preconceived skepticism from regulatory agencies \\
& Lengthy permitting process \\
\hline & Creation of hotspots, localized areas with high pollution levels \\
& Need for additional scientific data to evaluate the trading ratios \\
Uncertainty & Nonpoint source effluent reductions \\
& $\begin{array}{l}\text { Lack of trust among trading partners and regulatory agencies } \\
\text { Potential participants do not have a clear understanding of the marked-based } \\
\text { programs }\end{array}$ \\
\hline Cost associated with the quantification and monitoring of nonpoint sources \\
loadings \\
High transaction costs incurred when identifying trading partners, negotiating \\
and exchanging information
\end{tabular}


Table 2-3. Summary of some examples of water quality trading programs.

\begin{tabular}{|c|c|c|c|c|c|c|c|}
\hline Program & $\begin{array}{l}\text { Pollutant } \\
\text { /Trading } \\
\text { type }\end{array}$ & Goals & Ratios & $\begin{array}{l}\text { Credit Price } \\
\text { (US\$/kg) }\end{array}$ & $\begin{array}{l}\text { Market } \\
\text { Structure }\end{array}$ & Observations & References \\
\hline $\begin{array}{l}\text { 1. Neuse River } \\
\text { Basin TN } \\
\text { Trading Program, } \\
\text { NC, USA }\end{array}$ & $\begin{array}{l}\text { TN / } \\
\text { PS-PS } \\
\text { PS-NPS }\end{array}$ & $\begin{array}{l}\text { Collective } \\
\text { NPDES permit } \\
\text { (30\% reduction } \\
\text { or allowable } 485 \\
\text { mtons/yr) }\end{array}$ & $\mathrm{U}$ & $\begin{array}{l}\text { US\$ 24.2- } \\
62.5\end{array}$ & $\mathrm{C}$ & $\begin{array}{l}\text { - } 23 \text { facilities trade within a group } \\
\text { compliance association to meet an } \\
\text { overall cap for TN. } \\
\text { - } 69 \% \text { reduction of TN loads to the } \\
\text { estuary since } 1995 \text {. }\end{array}$ & $\begin{array}{l}\text { (USEPA, } \\
\text { 2008; } \\
\text { Hamstead and } \\
\text { BenDor, } \\
\text { 2010) }\end{array}$ \\
\hline $\begin{array}{l}\text { 2. Long Island } \\
\text { Sound TN Credit } \\
\text { Exchange } \\
\text { Program, CT, } \\
\text { USA }\end{array}$ & $\begin{array}{l}\text { TN / } \\
\text { PS-PS }\end{array}$ & $\begin{array}{l}\text { Multi-state } \\
\text { TMDL (58.5 \% } \\
\text { reduction) and } \\
\text { General NPDES } \\
\text { Permit }\end{array}$ & $\mathrm{D}$ & US\$ 3.6-10 & $\mathrm{C}$ & $\begin{array}{l}\text { - } 50 \% \text { reduction of the TN daily } \\
\text { loads from } 79 \text { facilities. } \\
\text { - Potential savings with TN trading } \\
\text { are in the US } \$ 300 \mathrm{M}-400 \mathrm{M} \text { range } \\
\text { over individual permitting } \\
\text { approaches. } \\
\text { - During } 2002-2009 \text {, } \\
\text { approximately } 15.5 \text { million credits } \\
\text { were traded, representing } \\
\text { US\$45.9M in economic activity. }\end{array}$ & $\begin{array}{l}\text { (USEPA, } \\
\text { 2008; } \\
\text { CTDEP, } \\
\text { 2010b) }\end{array}$ \\
\hline $\begin{array}{l}\text { 3. Lower St. } \\
\text { Johns River Pilot } \\
\text { Water Quality } \\
\text { Trading Program, } \\
\text { FL, USA }\end{array}$ & $\begin{array}{l}\text { TN, TP / } \\
\text { PS-PS } \\
\text { PS-NPS }\end{array}$ & $\begin{array}{l}\text { Allowable: } \\
\text { TMDL mtons/yr } \\
\text { Freshwater: } \\
\text { TN }=8,572 \\
\text { TP = 500 } \\
\text { Estuary: } \\
\text { TN = 1,377 } \\
\end{array}$ & $\mathrm{D} \& \mathrm{U}$ & $\begin{array}{l}\text { US\$ } 151.8 \\
\text { for TP }\end{array}$ & B, ThP & $\begin{array}{l}\text { - Two types of trading were } \\
\text { allowed, before and after BMAP } \\
\text { adoption. } \\
\text { - All credits exchange has been } \\
\text { from WWTF to MS4s. } \\
\text { - There has been only one credit } \\
\text { exchange with money involved. }\end{array}$ & $\begin{array}{l}\text { (FDEP, } \\
\text { 2010a; LSJR } \\
\text { TMDL } \\
\text { Executive } \\
\text { Committee, } \\
\text { 2011) }\end{array}$ \\
\hline
\end{tabular}


Table 2-3. Continued.

\begin{tabular}{|c|c|c|c|c|c|c|c|}
\hline Program & $\begin{array}{l}\text { Pollutant } \\
\text { /Trading } \\
\text { type }\end{array}$ & Goals & Ratios & $\begin{array}{l}\text { Credit Price } \\
\text { (US\$/kg) }\end{array}$ & $\begin{array}{l}\text { Market } \\
\text { Structure }\end{array}$ & Observations & References \\
\hline $\begin{array}{l}\text { 4. Great Miami } \\
\text { River Watershed } \\
\text { Trading Pilot, } \\
\text { OH, USA }\end{array}$ & $\begin{array}{l}\text { TP, TN / } \\
\text { PS-PS } \\
\text { PS-NPS }\end{array}$ & $\begin{array}{l}\text { A TMDL is in } \\
\text { place for one of } \\
\text { the three sub- } \\
\text { watersheds, and } \\
\text { TMDLs are } \\
\text { under } \\
\text { development for } \\
\text { the remaining } \\
\text { two sub- } \\
\text { watersheds }\end{array}$ & $\mathrm{D}, \mathrm{R}$ & $\begin{array}{l}\text { Cost estimate } \\
\text { range } \\
\text { (combined } \\
\text { TN \& TP) } \\
\text { US\$ 0.7-28.2 }\end{array}$ & C, ThP & $\begin{array}{l}\text { - The clearinghouse (credit bank) } \\
\text { was capitalized with money from } \\
\text { grants and from PS purchasing } \\
\text { credits. Farmers providing the } \\
\text { greatest TP reductions at the least } \\
\text { cost are funded from the credit } \\
\text { bank. Credits were then allocated } \\
\text { to investors based on their initial } \\
\text { investment amount. } \\
\text { - Create incentives (lower trading } \\
\text { ratios) for WWTFs that fund } \\
\text { nutrient reductions in advance of } \\
\text { their permit requirements. } \\
\text { - A total of } 49 \text { projects have been } \\
\text { funded, with payments totaling } \\
\text { US\$ 937,550. The projects have } \\
\text { produced 326 mtons in TP } \\
\text { reductions. } \\
\text { - Estimate cost savings of US\$ } \\
\text { 314M - 384M during a 20-year } \\
\text { period compared with traditional } \\
\text { approaches. }\end{array}$ & $\begin{array}{l}\text { (Kieser \& } \\
\text { Associates, } \\
\text { 2004; Graziani, } \\
\text { 2007; Hall, } \\
\text { 2009) }\end{array}$ \\
\hline $\begin{array}{l}\text { 5. Pennsylvania } \\
\text { Water Quality } \\
\text { Trading Program, } \\
\text { PA, USA }\end{array}$ & $\begin{array}{l}\text { TN, TP, } \\
\text { sediment / } \\
\text { PS-NPS }\end{array}$ & $\begin{array}{l}\text { Allowable: } \\
\text { TMDL } \\
\text { (mtons/yr) } \\
\text { TN = 33,534 TP } \\
=1,329 \\
\text { Sediment }= \\
\text { 899,823 }\end{array}$ & $\mathrm{D}, \mathrm{R}, \mathrm{EOS}$ & $\begin{array}{l}\text { For TN: } \\
\text { US\$ 6.6-33.1 } \\
\text { For TP: } \\
\text { US\$ 8.8-22 }\end{array}$ & EM, C & $\begin{array}{l}\text { - } 55 \text { projects have been approved. } \\
\text { Approximately } 1.7 \text { million TN } \\
\text { credits and 202,000 TP credits. } \\
\text { - Online trading tool (NutrientNet) } \\
\text { used to register, as a marketplace } \\
\text { and credit estimation tool. }\end{array}$ & $\begin{array}{l}\text { (PADEP, } \\
\text { 2009; } \\
\text { USEPA, } \\
\text { 2010; } \\
\text { Branosky et } \\
\text { al., 2011; } \\
\text { PADEP, } \\
\text { 2011) }\end{array}$ \\
\hline
\end{tabular}


Table 2-3. Continued.

\begin{tabular}{|c|c|c|c|c|c|c|c|}
\hline Program & $\begin{array}{l}\text { Pollutant } \\
\text { /Trading } \\
\text { type }\end{array}$ & Goals & Ratios & $\begin{array}{l}\text { Credit Price } \\
\text { (US\$/kg) }\end{array}$ & $\begin{array}{l}\text { Market } \\
\text { Structure }\end{array}$ & Observations & References \\
\hline $\begin{array}{l}\text { 6. South Nation } \\
\text { River Watershed } \\
\text { Trading Program, } \\
\text { Canada }\end{array}$ & $\begin{array}{l}\text { TP / } \\
\text { PS-NPS }\end{array}$ & $\begin{array}{l}\text { Allowable: } \\
\text { Zero increase in } \\
\text { TP loads for new } \\
\text { or expanded } \\
\text { WWTF }\end{array}$ & $\begin{array}{l}\text { Combined } \\
\text { U \& D }\end{array}$ & $\begin{array}{l}\text { Project } \\
\text { average cost: } \\
\text { US } \$ 410\end{array}$ & $\mathrm{C}$ & $\begin{array}{l}\text { - This program allows TP loading } \\
\text { offsetting from new or expanding } \\
\text { WWTFs by implementing NPS } \\
\text { BMPs. } \\
\text { - A fund allocates money to } \\
\text { farmers to pay for BMPs that } \\
\text { generate credits. The farmers are } \\
\text { paid for their projects and not to } \\
\text { reach kg of TP removed. } \\
\text { - PS may purchase credits from the } \\
\text { fund to offset their increased P } \\
\text { discharge. } \\
\text { - } 269 \text { verifiable trades were } \\
\text { completed from } 2000 \text { to 2009. The } \\
\text { estimated annual TP removal } \\
10,000 \mathrm{~kg}\end{array}$ & $\begin{array}{l}\text { (O'Grady, } \\
\text { 2006, 2011) }\end{array}$ \\
\hline
\end{tabular}


Table 2-3. Continued.

\begin{tabular}{|c|c|c|c|c|c|c|c|}
\hline Program & $\begin{array}{l}\text { Pollutant } \\
\text { /Trading } \\
\text { type }\end{array}$ & Goals & Ratios & $\begin{array}{l}\text { Credit Price } \\
\text { (US\$/kg) }\end{array}$ & $\begin{array}{l}\text { Market } \\
\text { Structure }\end{array}$ & Observations & References \\
\hline $\begin{array}{l}\text { 7. Hunter River } \\
\text { Salinity Trading } \\
\text { Scheme, } \\
\text { Australia }\end{array}$ & $\begin{array}{l}\text { Salinity / } \\
\text { PS-PS }\end{array}$ & $\begin{array}{l}\text { Allowable: } \\
900 \text { EC (lower } \\
\text { and middle } \\
\text { sector) } \\
600 \text { EC (upper } \\
\text { sector) }\end{array}$ & N/A & US\$526-983 & EM, B & $\begin{array}{l}\text { - Participants include } 23 \text { coal } \\
\text { mining and power generation } \\
\text { facilities, holding a total of } 1,000 \\
\text { salinity credits. } \\
\text { - The initial credits are issued with } \\
\text { different life spans (200 credits } \\
\text { expire every } 2 \text { years) and then } \\
\text { using a public auction to distribute } \\
200 \text { credits every } 2 \text { years. } \\
\text { - During high flow conditions, } \\
\text { each credit allows a discharger to } \\
\text { release up to 0.1\% of the Total } \\
\text { Allowable Discharge or sell the } \\
\text { credit to another participating } \\
\text { facility over the scheme's online } \\
\text { trading platform. During low flow } \\
\text { conditions, no discharges are } \\
\text { allowed, and during flood } \\
\text { conditions discharges are } \\
\text { unrestricted. } \\
\text { - Participants can continue to } \\
\text { purchase credits from other credit } \\
\text { holders as needed after the auction, } \\
\text { using the online trading website. }\end{array}$ & $\begin{array}{l}\text { (DECCW, } \\
\text { 2003; } \\
\text { Ferguson, } \\
\text { 2005; } \\
\text { DECCW, } \\
2009)\end{array}$ \\
\hline
\end{tabular}


Table 2-3. Continued.

\begin{tabular}{|c|c|c|c|c|c|c|c|}
\hline Program & $\begin{array}{l}\text { Pollutant } \\
\text { /Trading } \\
\text { type }\end{array}$ & Goals & Ratios & $\begin{array}{l}\text { Credit Price } \\
\text { (US\$/kg) }\end{array}$ & $\begin{array}{l}\text { Market } \\
\text { Structure }\end{array}$ & Observations & References \\
\hline $\begin{array}{l}\text { 8. Tar-Pamlico } \\
\text { Nutrient Trading } \\
\text { Program, NC, } \\
\text { USA }\end{array}$ & $\begin{array}{l}\text { TN, TP / } \\
\text { PS-PS PS- } \\
\text { NPS }\end{array}$ & $\begin{array}{l}\text { Allowable: } \\
\text { TMAL } \\
\text { (mtons/yr) } \\
\text { TN }=400 \\
\text { TP }=70\end{array}$ & U, R & $\begin{array}{l}\text { Phase I: } \\
\text { US\$ 55.1 } \\
\text { Phase II: } \\
\text { US\$ 28.7 }\end{array}$ & $\mathrm{C}$ & $\begin{array}{l}\text { - Point sources would meet nutrient } \\
\text { reduction goals by funding } \\
\text { agricultural BMPs. } \\
\text { - In Phase I: 16-member } \\
\text { association (94\% of the point } \\
\text { sources discharging into the basin) } \\
\text { has a common TN and TP cap. In } \\
\text { Phase II: nonpoint sources were } \\
\text { charged with a voluntary 30\% } \\
\text { nutrient reduction goal. } \\
\text { - Once PS have purchased credits, } \\
\text { they are no longer liable. The State } \\
\text { assumes responsibility for the } \\
\text { monitoring and verification of } \\
\text { BMPs. NPS in non-compliance } \\
\text { must return the cost-share funds. } \\
\text { - The Association has consistently } \\
\text { discharged below the nutrient cap } \\
\text { without engaging in trading. } \\
\text { - The program achieved its nutrient } \\
\text { reduction goal at a significantly } \\
\text { lower cost than initially projected. }\end{array}$ & $\begin{array}{l}\text { (Gannon, 2003; } \\
\text { Breetz et al., } \\
\text { 2004; Bacon } \\
\text { and Dupuis, } \\
\text { 2011) }\end{array}$ \\
\hline
\end{tabular}

Table 2-3. Continued.

\begin{tabular}{llllll}
\hline Program & $\begin{array}{l}\text { Pollutant } \\
\text { /Trading } \\
\text { type }\end{array}$ & Goals & Ratios & $\begin{array}{l}\text { Credit Price } \\
\text { (US\$/kg) }\end{array}$ & $\begin{array}{l}\text { Market Structure } \\
\text { Observations }\end{array}$ \\
\hline
\end{tabular}




\begin{tabular}{|c|c|c|c|c|c|c|c|}
\hline Program & $\begin{array}{l}\text { Pollutant } \\
\text { /Trading } \\
\text { type }\end{array}$ & Goals & Ratios & $\begin{array}{l}\text { Credit Price } \\
\text { (US\$/kg) }\end{array}$ & $\begin{array}{l}\text { Market } \\
\text { Structure }\end{array}$ & Observations & References \\
\hline $\begin{array}{l}\text { 9. Rahr Malting } \\
\text { Company Permit, } \\
\text { MN, USA }\end{array}$ & $\begin{array}{l}\text { TN, TP, } \\
\text { sediment to } \\
\text { create } \\
\text { CBOD }_{5} \\
\text { credits / } \\
\text { PS-NPS }\end{array}$ & $\begin{array}{l}\text { Allowable: } \\
24.9 \text { mtons/yr of } \\
\text { CBOD }_{5}(68 \\
\text { kg/day) }\end{array}$ & $\begin{array}{l}\text { Nutrient } \\
\text { conversion } \\
\text { ratios to } \\
\text { CBOD }_{5} \text {, } \\
\text { D, U }\end{array}$ & US\$ 18.9 & $\begin{array}{l}\text { Sole- } \\
\text { source } \\
\text { offsets, B }\end{array}$ & $\begin{array}{l}\text { - Rahr negotiated an agreement } \\
\text { with the Minnesota Pollution } \\
\text { Control Agency to offset } \\
\text { CBOD } 5 \text { discharged from its new } \\
\text { WWTF by funding upstream NPS } \\
\text { pollutant reductions. } \\
\text { - NPS BMP sites must be upstream } \\
\text { of Shakopee in the Minnesota } \\
\text { River Basin. } \\
\text { - Rahr was required to establish a } \\
\text { US\$ 250,000 trust fund within the } \\
\text { 5-year permit term to pay for its } \\
\text { NPS offsets. In } 5 \text { years, Rahr } \\
\text { achieved the needed NPS loading } \\
\text { reductions through } 4 \text { NPS offsets. }\end{array}$ & $\begin{array}{l}\text { (MPCA, 1997; } \\
\text { Breetz et al., } \\
\text { 2004; Selman } \\
\text { et al., 2009) }\end{array}$ \\
\hline $\begin{array}{l}\text { 10. Red Cedar } \\
\text { River Nutrient } \\
\text { Trading Pilot } \\
\text { Program, WI, } \\
\text { USA }\end{array}$ & $\begin{array}{l}\text { TP / } \\
\text { PS-NPS }\end{array}$ & $\begin{array}{l}\text { Allowable: } \\
2 \text { mtons/yr }\end{array}$ & $\mathrm{U}$ & US\$ 4.1 & B & $\begin{array}{l}\text { - The City of Cumberland POTW } \\
\text { used water quality trading to reduce } \\
\text { compliance costs ( } 1 \mathrm{mg} / \mathrm{L} \mathrm{TP} \\
\text { discharge limit). } \\
\text { - Farmers can only receive payment } \\
\text { for a BMP for } 3 \text { years. As of } 2004 \text {, } \\
\text { the City of Cumberland has paid a } \\
\text { total of US\$ 58,000 to remove } 14.3 \\
\text { mtons of TP. }\end{array}$ & $\begin{array}{l}\text { (Breetz et al., } \\
\text { 2004; Selman } \\
\text { et al., 2009) }\end{array}$ \\
\hline
\end{tabular}

Table 2-3. Continued.

\begin{tabular}{|c|c|c|c|c|c|c|c|}
\hline Program & $\begin{array}{l}\text { Pollutant } \\
\text { /Trading } \\
\text { type }\end{array}$ & Goals & Ratios & $\begin{array}{l}\text { Credit Price } \\
\text { (US\$/kg) }\end{array}$ & $\begin{array}{l}\text { Market } \\
\text { Structure }\end{array}$ & Observations & References \\
\hline
\end{tabular}




\begin{tabular}{|c|c|c|c|c|c|c|c|}
\hline Program & $\begin{array}{l}\text { Pollutant } \\
\text { /Trading } \\
\text { type }\end{array}$ & Goals & Ratios & $\begin{array}{l}\text { Credit Price } \\
\text { (US\$/kg) }\end{array}$ & $\begin{array}{l}\text { Market } \\
\text { Structure }\end{array}$ & Observations & References \\
\hline $\begin{array}{l}\text { 11. Virginia } \\
\text { Water Quality } \\
\text { Trading Program, } \\
\text { VA, USA }\end{array}$ & $\begin{array}{l}\text { TN, TP / } \\
\text { PS-PS } \\
\text { PS-NPS }\end{array}$ & $\begin{array}{l}\text { General VPDES } \\
\text { permit. } \\
\text { Concentration } \\
\text { for annual WLAs } \\
\text { vary by river } \\
\text { basin }\end{array}$ & $\mathrm{U}$ & $\begin{array}{l}\text { For TN: } \\
\text { US\$ } 24.4 \\
\text { For TP: } \\
\text { US\$ } 11.1\end{array}$ & C, B & $\begin{array}{l}\text { - PS accommodate growth by } \\
\text { purchasing offsets in the form of } \\
\text { WLAs from other PS or offsets from } \\
\text { NPS. } \\
\text { - Sellers must meet baseline } \\
\text { requirements before selling offsets } \\
\text { and before generating credits. } \\
\text { Agricultural operations must first } \\
\text { comply with a state nutrient } \\
\text { reduction goal. } \\
\text { - There are } 127 \text { existing and } 12 \\
\text { new/expanding facilities eligible for } \\
\text { participation. }\end{array}$ & $\begin{array}{l}\text { (VDEQ, } \\
\text { 2008; } \\
\text { Stephenso } \\
\text { n et al., } \\
\text { 2010) }\end{array}$ \\
\hline $\begin{array}{l}\text { 12. Cherry Creek } \\
\text { Reservoir } \\
\text { Watershed } \\
\text { Phosphorus } \\
\text { Trading Program, } \\
\text { CO, USA }\end{array}$ & $\begin{array}{l}\text { TP / } \\
\text { PS-PS } \\
\text { PS-NPS }\end{array}$ & $\begin{array}{l}\text { Allowable: } \\
6 \text { mtons/yr or } \\
40 \mu \mathrm{g} / \mathrm{L}\end{array}$ & $\mathrm{D}, \mathrm{U}$ & US\$17,632 & $\begin{array}{l}\text { Sole- } \\
\text { source } \\
\text { offsets, C }\end{array}$ & $\begin{array}{l}\text { - The trading program identifies two } \\
\text { types of projects: 1) New trade } \\
\text { projects allowing entities in the } \\
\text { watershed to construct NPS TP } \\
\text { projects for credit trading to respond } \\
\text { to the continued population growth, } \\
\text { and 2) Historic trade projects } \\
\text { including } 4 \text { projects constructed by } \\
\text { the water quality authority between } \\
1991 \text { and 1997. These projects made } \\
\text { up a 'phosphorus bank' of } 98 \text { kg of } \\
\text { credits, available for purchase. } \\
\text { - This (Department of Environmental } \\
\text { Quality, 2000) program has provided } \\
\text { ancillary environmental benefits such } \\
\text { as flood control and wildlife habitat. }\end{array}$ & $\begin{array}{l}\text { (WERF, } \\
\text { 2001; } \\
\text { Earles et } \\
\text { al., 2008) }\end{array}$ \\
\hline
\end{tabular}


Table 2-3. Continued.

\begin{tabular}{|c|c|c|c|c|c|c|c|}
\hline Program & $\begin{array}{l}\text { Pollutant } \\
\text { /Trading } \\
\text { type }\end{array}$ & Goals & Ratios & $\begin{array}{l}\text { Credit Price } \\
\text { (US\$/kg) }\end{array}$ & $\begin{array}{l}\text { Market } \\
\text { Structure }\end{array}$ & Observations & References \\
\hline $\begin{array}{l}\text { 13. Kalamazoo } \\
\text { River Phosphorus } \\
\text { Trading } \\
\text { Demonstration } \\
\text { Program, MI, } \\
\text { USA }\end{array}$ & $\begin{array}{l}\text { TP / } \\
\text { PS-NPS }\end{array}$ & $\begin{array}{l}\text { Allowable: } \\
\text { Steady WLA of } \\
1 \mathrm{mg} / \mathrm{L}\end{array}$ & $\mathrm{U}$ & $\begin{array}{l}\text { No credits } \\
\text { were } \\
\text { purchased }\end{array}$ & $\mathrm{C}$ & $\begin{array}{l}\text { - A multi-disciplinary steering } \\
\text { committee directs and oversees the } \\
\text { project. } \\
\text { - Six NPS projects were implemented } \\
\text { to generate credits for trading; } \\
\text { estimated load reduction is of } 972 \mathrm{~kg} \\
\text { of TP. } \\
\text { - PS could purchase credits to } \\
\text { accommodate growth but not to } \\
\text { discharge above their NPDES limits. } \\
\text { - No actual trades occurred because } \\
\text { the main PS discharger went out of } \\
\text { business. }\end{array}$ & $\begin{array}{l}\text { (Kieser \& } \\
\text { Associates, } \\
\text { 2004) }\end{array}$ \\
\hline
\end{tabular}

B: Bilateral; BMAP: Basin Management Action Plan; BMPs: Best Management Practices;

C: Clearinghouse; $\mathrm{CBOD}_{5}$ : Carbonaceous Biochemical Oxygen Demand;

D: Delivery ratio; EC: Electrical conductivity units; EM: Exchange market; EOS: Edge of segment factor;

MS4s: Municipal Separate Stormwater Sewer System; NPDES: National Pollutant Discharge Elimination System; NPS: Nonpoint sources;

POTW: Publicly Owned Treatment Works; PS: Point sources; R: Reserve ratio; ThP: Third party; TMAL: Total Maximum Annual Load; TN: Total Nitrogen;

ThP: Third party; TP: Total Phosphorus; U: Uncertainty ratio; R: Reserve ratio; VPDES: Virginia Pollutant Discharge Elimination System;

WLAs: Waste Load Allocations; WWTF: Wastewater Treatment Facilities;

All the credit costs were converted to US\$ (September 2011 currency converting rate). The credit price is reported per kg of pollutant removed (except for the Hunter River Salinity Trading Scheme, Australia). 
Table 2-4. Correlation between elements of a water quality trading program and the program success, involving point and agricultural nonpoint sources.

\begin{tabular}{|c|c|c|c|c|c|c|}
\hline \multirow[b]{2}{*}{ Program } & \multirow[b]{2}{*}{$\begin{array}{l}\text { Policy } \\
\text { Drivers }\end{array}$} & \multicolumn{4}{|c|}{ Evaluation Criteria } & \multirow[b]{2}{*}{$\begin{array}{c}\text { Success } \\
\text { (ease of trading }\end{array}$} \\
\hline & & $\begin{array}{c}\text { Minimization } \\
\text { of } \\
\text { Uncertainty }\end{array}$ & Flexibility & $\begin{array}{l}\text { Trading } \\
\text { Activity }\end{array}$ & $\begin{array}{c}\text { Social } \\
\text { Embeddedness }\end{array}$ & \\
\hline Great Miami River Watershed Trading Pilot & $+/-$ & + & $+/-$ & + & + & + \\
\hline $\begin{array}{l}\text { Pennsylvania Water Quality Trading } \\
\text { Program }\end{array}$ & + & + & $+/-$ & + & + & + \\
\hline $\begin{array}{l}\text { Lower St. Johns River Pilot Water Quality } \\
\text { Trading Program }\end{array}$ & + & $+/-$ & $+/-$ & + & $+/-$ & - \\
\hline $\begin{array}{l}\text { Kalamazoo River Phosphorus Trading } \\
\text { Demonstration Program }\end{array}$ & - & $+/-$ & + & - & + & + \\
\hline $\begin{array}{l}\text { Red Cedar River Nutrient Trading Pilot } \\
\text { Program }\end{array}$ & $+/-$ & + & - & + & + & - \\
\hline $\begin{array}{l}\text { South Nation River Watershed Trading } \\
\text { Program }\end{array}$ & + & $+/-$ & + & + & + & + \\
\hline Tar-Pamlico Nutrient Trading Program & + & + & $+/-$ & - & + & + \\
\hline Rahr Malting Company Permit & + & + & - & + & - & - \\
\hline $\begin{array}{l}\text { Cherry Creek Reservoir Watershed } \\
\text { Phosphorus Trading Program }\end{array}$ & + & + & $+/-$ & + & + & + \\
\hline $\begin{array}{l}\text { Lower Boise River Effluent Trading } \\
\text { Demonstration Project }\end{array}$ & + & + & $+/-$ & - & - & - \\
\hline Total & 8 & 8.5 & 5 & 7 & 7 & 6 \\
\hline Binomial Correlation & 0.80 & 0.85 & 0.50 & 0.70 & 0.70 & 0.60 \\
\hline
\end{tabular}




\subsection{Figures}

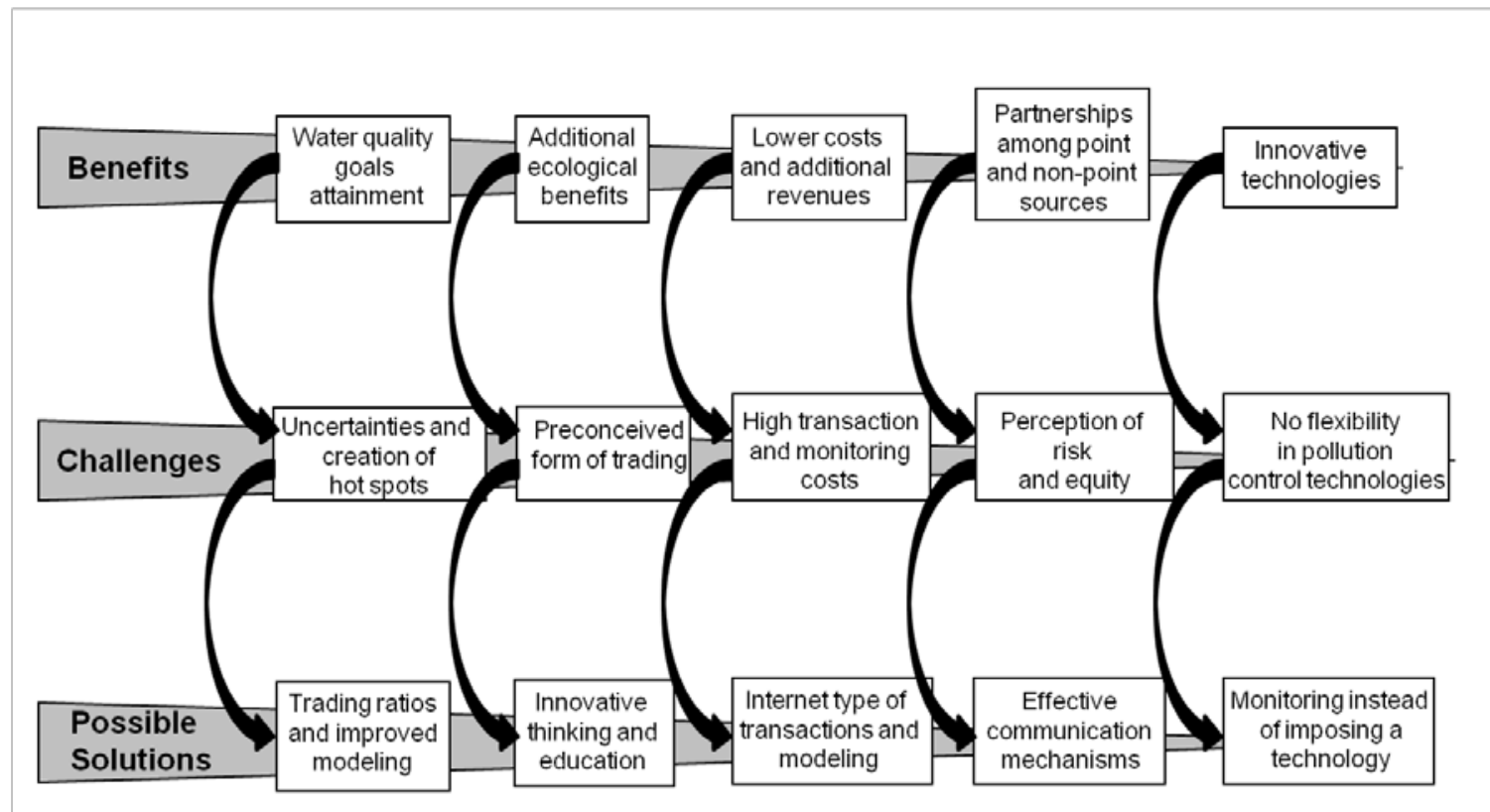

Figure 2-1. Key benefits and challenges of water quality trading programs with some of the suggested solutions.

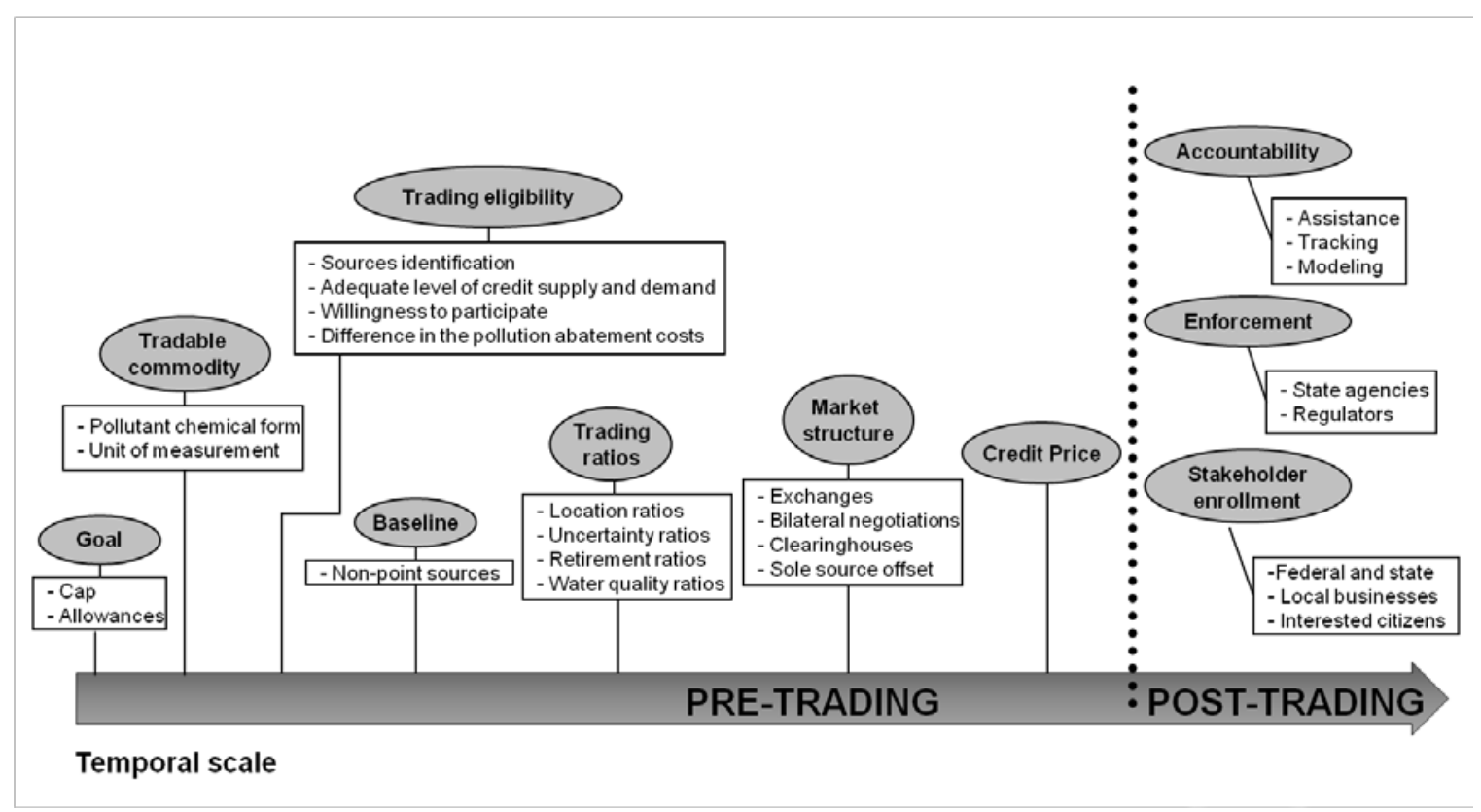

Figure 2-2. Key elements of a water quality trading program, pre and post trading in a temporal perspective. 


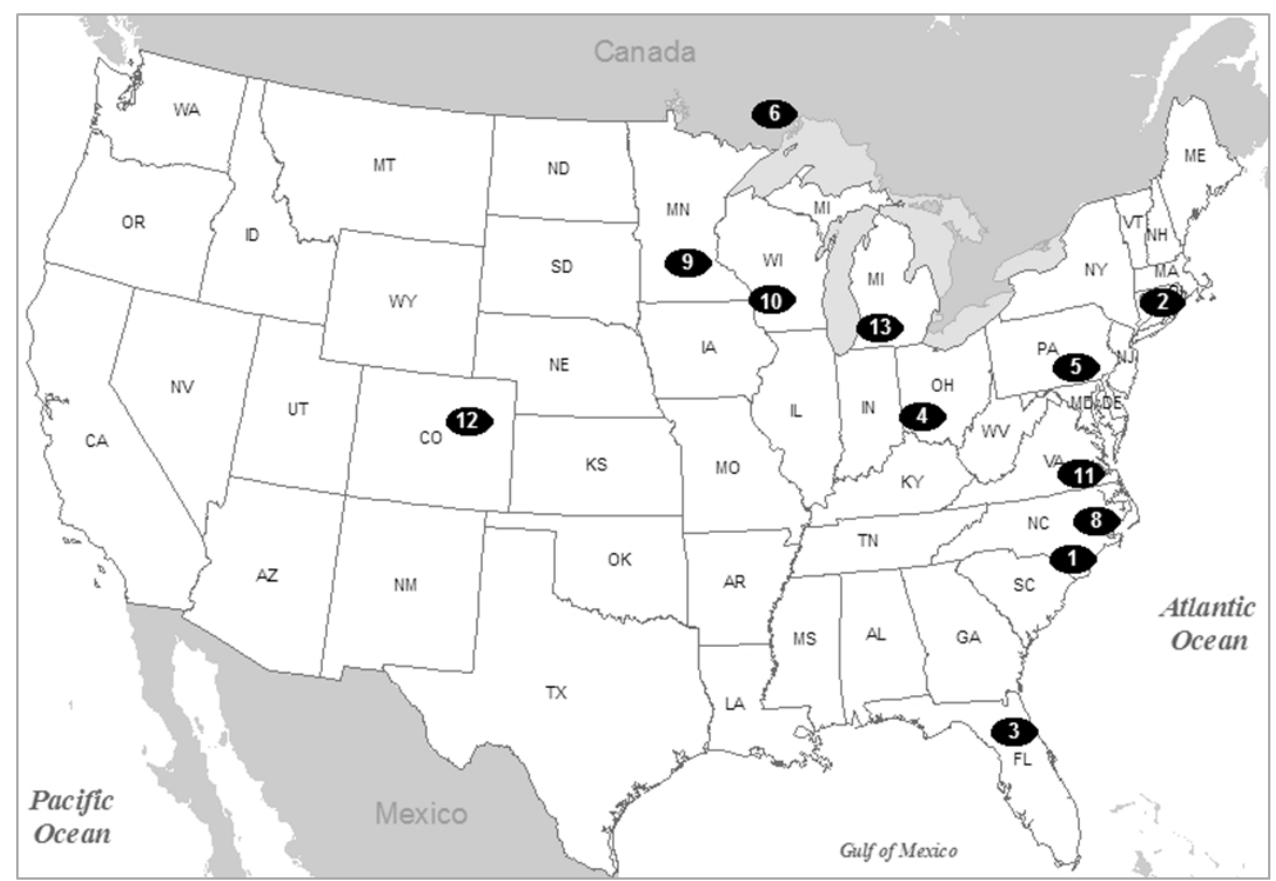

1: Neuse River Basin TN Trading Program, NC, USA

2: Long Island Sound TN Credit Exchange Program, CT, USA

3: Lower St. Johns River Pilot Water Quality Trading Program, FL, USA

4: Great Miami River Watershed Trading Pilot, OH, USA

5: Pennsylvania Water Quality Trading Program, PA, USA

6: South Nation River Watershed Trading Program, Canada

8: Tar-Pamlico Nutrient Trading Program, NC, USA

9: Rahr Malting Company Permit, MN, USA

10: Red Cedar River Nutrient Trading Pilot Program, WI, USA

11: Virginia Water Quality Trading Program, VA, USA

12: Cherry Creek Reservoir Watershed Phosphorus Trading Program, CO, USA

13: Kalamazoo River Phosphorus Trading Demonstration Program, MI, USA

Figure 2-3. Locations of some water quality trading programs in North America. The remaining water quality trading program discussed is located in Australia. 


\section{CHAPTER 3}

\section{MODELING A PHOSPHORUS CREDIT TRADING PROGRAM IN AN}

\section{AGRICULTURAL WATERSHED}

Corrales J, Naja GM, Bhat MG, Miralles-Wilhelm F. 2014. Modeling a phosphorus credit trading program in an agricultural watershed. Journal of Environmental Management 143: $162-172$.

\subsection{Abstract}

Water quality and economic models were linked to assess the economic and environmental benefits of implementing a phosphorus credit trading program in an agricultural sub-basin of Lake Okeechobee watershed, Florida, United States. The water quality model determined the effects of rainfall, land use type, and agricultural management practices on the amount of total phosphorus (TP) discharged. TP loadings generated at the farm level, reaching the nearby streams, and attenuated to the sub-basin outlet from all sources within the sub-basin, were estimated at 106.4, 91, and 85 mtons $\mathrm{yr}^{-1}$, respectively. Almost 95\% of the TP loadings reaching the nearby streams were attributed to agriculture sources, and only $1.2 \%$ originated from urban areas, accounting for a combined TP load of 87.9 mtons $\mathrm{yr}^{-1}$. In order to compare a Least-Cost Abatement approach to a Command-and-Control approach, the most cost effective cap of 30\% TP reduction was selected, and the individual allocation was set at a TP load target of $1.6 \mathrm{~kg}$ $\mathrm{ha}^{-1} \mathrm{yr}^{-1}$ (at the nearby stream level). The Least-Cost Abatement approach generated a potential cost savings of 27\% ( $\$ 1.3$ million per year), based on an optimal credit price of \$179. Dairies (major buyer), ornamentals, row crops, and sod farms were identified as potential credit buyers, whereas citrus, improved pastures (major seller), and urban areas 
were identified as potential credit sellers. Almost $81 \%$ of the TP credits available for trading were exchanged. The methodology presented here can be adapted to deal with different forms of trading sources, contaminants, or other technologies and management practices.

\subsection{Introduction}

Nutrient over-enrichment of freshwater lakes, streams, and reservoirs is a rapidly growing environmental problem, severely impacting freshwater resources worldwide. Many of the world's freshwater lakes suffer from eutrophication including Lake Erie and Lake Okeechobee (United States), Lake Victoria (Tanzania/Uganda/Kenya), and Tai Lake (China), among others. The rise in eutrophic events is generally attributed to the rapid increase in intensive agricultural practices, industrial activities, and population growth which have increased nutrient flows into the environment.

Lake Okeechobee, the largest lake in the southeastern United States $\left(1890 \mathrm{~km}^{2}\right)$, is located in the center of the greater Florida Everglades ecosystem. It constitutes a critical link between lakes and rivers to the north, wetlands and bays to the south, and estuaries to the east and west. The environmental health of the Lake has been degraded as wetlands and natural habitats in the Lake Okeechobee watershed have been replaced with farms, urban areas, and dairy operations. Excessive phosphorus loadings from these diverse sources - including agriculture and livestock, municipal and industrial wastewater discharges, and urban stormwater runoff - have been identified as the leading causes of the Lake's impairment (FDEP, 2001). In order to protect the Lake and its designated uses (e.g., drinking, fishing, recreation, irrigation), a phosphorus Total Maximum Daily Load 
(TMDL) for it was adopted in 2001. This TMDL establishes an annual target load of 140 mtons of total phosphorus (TP) to Lake Okeechobee, including atmospheric deposition (35 mtons) and the sum of all TP-bearing surface water inputs to the Lake (105 mtons) (Zhao et al., 2012). Watershed projects, along with on-site agricultural and urban Best Management Practices (BMPs), are being implemented to reduce TP transport from uplands and capture runoff during high rainfall periods. BMPs are individual or combined management practices usually classified into management or structural practices. Management practices, such as efficient use of fertilizers, are ownerimplemented BMPs. Structural practices involving the construction of more capitalintensive BMPs, are generally divided into typical practices (i.e., erosion control, etc.) and alternative practices (i.e., edge-of-farm stormwater retention/detention, etc.) (FDACS, 2011; SWET, 2006). Despite the high number of acres enrolled in the BMP program, a large percentage of the lands have neither reached the full level of typical/owner BMP implementation, nor have adopted more efficient alternative BMPs. This is mainly due to lack of funding and to the high costs associated with more advanced and efficient chemical treatments (FDACS, 2011). Consequently, the establishment of innovative economic incentives is essential to drive landowners to implement BMPs to their full extent.

Water quality trading programs have emerged as a promising alternative to assist in meeting nutrient water quality standards at an overall lower cost (Corrales et al., 2013; Kardos and Obropta, 2011). Studies conducted for the Great Miami River Watershed Trading Pilot program and for the Long Island Sound Nitrogen Credit Exchange reported cost saving estimates of \$314 to \$385 million (Kieser \& Associates, 2004) and \$200 
million (CTDEP, 2010), respectively for each program. Trading allows one polluting source to meet its regulatory obligations by using pollution reductions achieved by another source with lower abatement costs (King and Kuch, 2003). The latter, in turn, obtains revenue for their efforts in reducing pollution. Because trading programs are expected to reduce the overall cost of complying with water quality goals, environmental agencies have recently focused their effort on this type of programs over traditional Command-and-Control approaches for water pollution control. Command-and-Control approaches are generally cost-inefficient and consist of implementing technologies that agencies deem to be most effective for controlling the amount of pollutant that may be emitted by pollution sources, with violators facing rigid financial penalties (Field and Field, 2006; Mariola, 2009; Paniccia, 2002).

The main objective of this study was to assess the economic and environmental benefits of implementing a phosphorus environmental credit trading program, as compared to a Command-and-Control approach. The S-191 sub-basin located within the Lake Okeechobee watershed was selected as a model focus area. A computational methodology coupling a water quality model to an economic model was developed in order to identify P-credits buyers and sellers, determine the optimal credit price, and assess the cost savings of a nutrient credits trading program. A complete trading scenario was detailed to assess the cost-effectiveness of a water quality trading program in the studied sub-basin. The specific objectives included simulating the optimal combination of BMPs to minimize the cost of achieving a specific phosphorus reduction goal, assessing the delivery trading ratios, and estimating the costs savings of a Least-Cost Abatement scenario versus a Command-and-Control approach. 


\subsection{Materials and Methods}

\subsubsection{Study area description}

The study area is the S-191 sub-basin located in Taylor Creek / Nubbin Slough Lake Okeechobee sub-watershed in southern Florida, directly north of Lake Okeechobee (Fig. 3-1a). The sub-basin covers 48,470 hectares of a flat landscape with generally poorly drained soils characterized by a low phosphorus retention capacity (Zhao et al., 2012). This investigated area consists of a collection of tributary streams flowing into Lake Okeechobee through the S-191 flow control structure (Fig. 3-1b). The main tributaries are Taylor Creek, Nubbin Slough, Henry Creek, Lettuce Creek, Mosquito Creek, and Myrtle Slough (Fig. 3-1b). The annual average rainfall in the investigated sub-basin is 1,168 mm (Zhao et al., 2012), and the land use classification is composed of agriculture accounting for approximately 74\%, followed by forested areas (11\%) and wetlands (9\%). Runoffs from farms have been identified as the major source of the TP water quality problem in the S-191 sub-basin (Gale et al., 1993). Even though this sub-basin covers only about $3.5 \%$ of the drainage area in Lake Okeechobee watershed, it annually contributed about 34 mtons of TP to the Lake (during the last five years) (SFWMD, 2010), representing 32\% of the TMDL. In addition, $99 \%$ of this sub-basin’s waterbodies have been verified as impaired (USEPA, 2008). Therefore, local authorities have listed this sub-basin as a top priority basin for TP reductions.

The present study used a modeling framework, illustrated in greater detail in Supplemental Fig. 3-S1, integrating a basin-wide hydrology / water quality model and an economic model to assess the cost-benefit of implementing a phosphorus credit trading program in the S-191 sub-basin. The hydrology and water quality model captured the 
effects of rainfall, land use management practices, and soil characteristics on water flows and phosphorus loads generated and transported within the basin and reaching the Lake. The results of the hydrology and water quality model were then used as input data for the economic model to identify the nutrient management practices, achieving a targeted load reduction at the lowest total cost.

\subsubsection{Hydrology and water quality modeling}

Description of the model

The Watershed Assessment Model (WAM) developed by Soil Water Engineering Technology (SWET), Inc. was used in this study to perform hydrology and water quality analysis in the S-191 sub-basin. WAM is a Geographic Information System (GIS) based model that simulates surface and ground water flow and nutrient constituents on a daily basis based on the detailed physical properties of the watershed, underlying hydrogeological system, and land use management practices (SWET, 2011a). WAM has been already calibrated and validated for the northern Lake Okeechobee watershed to characterize the hydrology and water quality of the watershed (HDR, 2004). WAM was also specifically calibrated (calibration period 2002-2004) and validated (validation period 2005-2009) for the S-191 sub-basin, where different Goodness-of-Fit (GOF) statistic measures indicated that the WAM model results closely fitted the observed hydrology and constituent loading data. During the calibration period, the Root Mean Square Error (RMSE), Mean Bias Error (MBE), and the Nash-Sutcliffe coefficient of efficiency (NS) obtained for monthly flows at the S-191 structure were $2.96 \mathrm{~m}^{3} \mathrm{~s}^{-1}, 0.17$ $\mathrm{m}^{3} \mathrm{~s}^{-1}$, and 0.90 , respectively. During the validation period, the RMSE, MBE, and NS

obtained for monthly flows at the same structure were $2.45 \mathrm{~m}^{3} \mathrm{~s}^{-1}, 0.25 \mathrm{~m}^{3} \mathrm{~s}^{-1}$, and 0.84 , 
respectively. The RMSE, MBE, and NS obtained for monthly TP loadings at the S-191 structure during the calibration period were $7,383 \mathrm{~kg}, 174 \mathrm{~kg}$, and 0.88 , respectively and during the validation period, those values were $5,345 \mathrm{~kg}, 1,545 \mathrm{~kg}$, and 0.77 , respectively (SWET, 2011b).

The WAM model has been used in different studies to assess the nutrient assimilation, and to conduct nutrient and water budgets throughout the Lake Okeechobee watershed (Chebud et al., 2011; SFWMD et al., 2011; SWET, 2011a; SWET and JGH Engineering, 2007; USEPA, 2008). The WAM model provides a spatial representation of nutrient sources and transport processes (McCormick et al., 2011), and allows for the assessment of the effectiveness of current and future management practices in the watershed.

Input / output data

Input GIS data required for the WAM model set-up are land use, soil, rainfall stations, topography, reach network, and basin drainage areas. Optional information includes wastewater utility zone, point source locations, water control structures, and springshed areas. Time series dataset consist of rainfall, flow, stage, and water quality data (SWET, 2011a). In this study, the 2006 land use classification was obtained from the South Florida Water Management District (SFWMD) using the Florida Land Use, Cover, and Forms Classification System (FLUCCS) to define the land use types (SFWMD, 2013). Soil, topography, and hydrography data were obtained from the US Department of Agriculture, Natural Resource Conservation Service database (USDA, 2013). Rainfall data was collected from the SFWMD's DBHYDRO database from four rainfall monitoring sites (Fig. 3-1b) for the model simulation period (1999 to 2009), including a 
three-year model spin-up period (from 1999 to 2001) that allows for the variables to stabilize. The output results were obtained from 2002 through 2009.

The model interface provides different formats for reviewing the output data such as 1) tables to compare annual average loads for different land uses under different management scenarios, 2) graphs to assess flow and constituent time series in each reach or to compare model output with monitored data, and 3) maps to understand the spatial distribution of the annual averages flows and loads generated in each source cell within the basin. The constituent loads and concentrations can be examined based on their unattenuated (amounts generated at the farm levels) or attenuated values (amounts reaching the nearby stream) after the overland attenuation had been accounted for.

\section{In-stream phosphorus attenuation analysis}

WAM uses an algorithm that routes and attenuates the farm level nutrient loads to the nearest stream based on distance, flow rate, and land use conditions between the source and the nearby stream. An additional algorithm was developed here. A first order decay equation, Equation (3-1), adopted from SWET (2011a), was used to attenuate TP load from the nearby stream to the sub-basin outlet. As the two main forms of phosphorus, dissolved (soluble - SP) and attached to the sediments (particulate - PP), are transported through the stream network, they could be partially attenuated through diverse biophysico-chemical assimilation processes. The main factors driving these processes are the stream velocity and rate of nutrient exchange between the water column and sediments. A similar methodology was used by Chebud et al. (2010), Reddy et al. (1999), and Zhang et al. (2002) to assess phosphorus attenuation in Lake Okeechobee watershed. 
$C_{f}=C_{b}+\left(C_{o}-C_{b}\right) * e^{\left(-\frac{a}{v}\right)}$

where $C_{f}$ is the TP concentration at the outlet of the sub-basin $\left(\mathrm{mg} \mathrm{L}^{-1}\right), C_{o}$ is the TP concentration at the outlet of each reach segment $\left(\mathrm{mg} \mathrm{L}^{-1}\right), C_{b}$ is the TP background concentration in the stream $\left(\mathrm{mg} \mathrm{L}^{-1}\right), v$ is the stream velocity $\left(\mathrm{m} \mathrm{s}^{-1}\right)$, and $a$ is the rate of load transfer $\left(\mathrm{m} \mathrm{s}^{-1}\right)$ referring to the rate at which TP is removed from the water column and retained in the stream sediments (Reddy et al., 1999). Values of $C_{b}$ and $a$ were obtained from the WAM documentation (SWET, 2011a) and were calibrated for the watershed. For the Soluble Phosphorus (SP), $C_{b}$ and $a$ values were $0.02 \mathrm{mg} \mathrm{L}^{-1}$ and $0.00015 \mathrm{~m} \mathrm{~s}^{-1}$, respectively. For the Particulate Phosphorus (PP), $C_{b}$ and $a$ values were $0.02 \mathrm{mg} \mathrm{L}^{-1}$ and $0.0015 \mathrm{~m} \mathrm{~s}^{-1}$, respectively.

The S-191 sub-basin was then divided into zones with similar attenuation values, which are ratios calculated from the TP load attenuated to the sub-basin outlet and the TP load attenuated to the nearby stream. The attenuation values were then used to determine the trading ratios required to balance the TP loads from trading sources located at a different distance from the sub-basin outlet. This delivery type of ratio is commonly set to account for pollutant attenuation throughout a watershed before reaching the impaired waterbody. The trading ratio determined here is based on the stream velocity and load transfer (the slower the rate the pollutant has to travel, the greater the attenuation will be).

\subsubsection{Economic modeling}

Description of the Least-Cost Abatement model

Several studies used empirical models to determine Least-Cost Abatement approaches to comply with water quality standards and nutrient reduction goals (Kieser \& 
Associates, 2004; Paniccia, 2002; Schleich and White, 1997; Schwartz, 2010). In the present study, a conceptual model was developed to determine the optimal combination of BMPs in order to reach an emission reduction goal at the minimum cost, assess the optimal credit price, and quantify the cost-savings achieved while implementing a credit trading program in the S-191 sub-basin. The conceptual Linear Programming (LP) model, Equations (3-2) - (3-4), was formulated using the General Algebraic Modeling System (GAMS) software. The objective function Min Z, represented in Equation (3-2), was set to minimize the cost of implementing BMPs and new treatment technologies for point and non-point sources, respectively. This would be the objective of a planner with regard to the proposed TP trading program: minimization of the basin-wide total costs of abating TP loading.

$\operatorname{Min} Z=\sum_{i} \sum_{k} \sum_{j} c_{i, k, j} \times X_{i, k, j}$

Subject to:

$\sum_{i} \sum_{k} \sum_{j} L_{i, j} \times r_{k, j} \times X_{i, k, j} \geq$ Target_ $P_{r e d}$

$\sum_{k} X_{i, k, j} \leq 1 \quad \forall i, k, j$

where the sub-indices $i, j$, and $k$ represent the number of zones, the type of land use, and the BMP or technology type, respectively. $c_{i, k, j}$ is the annual cost $\left(\$ \mathrm{yr}^{-1}\right)$ of implementing a BMP or a new technology type $(k)$ at a land use $(j)$ in zone $(i) . X_{i, k, j}$ is a binary variable with a value of 1 if a BMP or a new technology type (k) is implemented, 0 otherwise. $r_{k, j}$ is the TP load reduction (\%) attained when implementing a BMP or a new technology type $(k)$ at land use $(j) . L_{i, j}$ is the current TP load $\left(\mathrm{kg} \mathrm{yr}^{-1}\right)$ in the runoff from land use $(j)$ 
located in zone (i), and Target_Pred is the TP load reduction $\left(\mathrm{kg} \mathrm{yr}^{-1}\right)$ in the runoff at the zone level when following the Command-and-Control approach. Supplemental Tables 3S1, 3-S2 and 3-S3 list the available three types of BMPs per land use (owner, typical, and alternative), the corresponding costs, and TP removal efficiencies, respectively.

The first constraint, Equation (3-3), reflects that the sum of TP load reductions from all sources or land uses $(j)$ in each zone (i), after implementing a BMP or a new technology type $(k)$, needs to meet an established TP load reduction target (Target_Pred) at the zone level. The second constraint, Equation (3-4), is using a binary variable (0 or 1$)$ to indicate if a BMP or a new technology is implemented or not. For instance, a value of 1 is used when a BMP type $(k)$ was adopted by land use $(j)$ in zone (i), and 0 otherwise.

The developed model code contained one decision making variable, two constraints, and allowed for the direct reading of the: 1) minimum cost of implementing several management practices to reduce TP loads within the sub-basin in order to achieve a predetermined goal or reduction target, 2) optimal mix of BMP and technology types per point and non-point sources to be implemented in order to cost-effectively reduce TP loads in the sub-basin, 3) TP amount reduced, and 4) total cost of BMP or technology implementation for each land use.

\section{Input / output data}

The four input data required to run the economic model were: 1) current TP loads per area in the runoff from the different land use types obtained from the output results of the hydrology and water quality WAM modeling, 2) surface area of the land use types per zone estimated using ArcGIS tools (presented in Supplemental Table 3-S4), 3) annual cost of implementing the three BMP types (i.e., owner, typical, and alternative) per land 
use obtained from SWET (2006), and 4) TP load reduction efficiency per BMP type and per land use also obtained from SWET (2006). Similar data were needed for point sources regarding the implemented technologies. However, since the point sources in the investigated sub-basin were dairies, the implemented technologies were also considered as BMP types. Note that the annual costs included the operational and maintenance costs and were indexed to 2012 dollars using the Consumer Price Index inflation calculation.

\subsubsection{Phosphorus trading analysis}

In order to determine the potential cost savings of implementing a TP trading program in the sub-basin, two abatement scenarios were assumed: (a) a Command-andControl program, which is usually a non-market, regulatory program, and (b) a LeastCost Abatement scenario. Under the first scenario, the desired reduction target or cap was set, and then the target was allocated across all sources using a pre-defined rule. The second scenario is the market outcome expected to occur if landowners were to engage in trading once the allocation is determined. The Least-Cost Abatement model presented in Equations (3-2) - (3-4) was used to determine the least-cost management strategy and the corresponding reduction levels of each source. The entire TP trading in the S-191 subbasin was assessed using six steps illustrated in Supplemental Fig. 3-S1b and explained in the Supplemental Information section. 


\subsection{Results and Discussion}

\subsubsection{Hydrology and water quality modeling}

\section{Runoff and percolation}

The annual average values of water runoff and percolation within the S-191 sub-basin were 20.0 and $6.4 \mathrm{~cm} \mathrm{yr}^{-1}$, respectively, for a simulation period from years $2002-2009$. The average runoff value presented here was comparable to average values of $27.4 \mathrm{~cm} \mathrm{yr}^{-}$ ${ }^{1}$ (time period 1991 - 2005) and $30.2 \mathrm{~cm} \mathrm{yr}^{-1}$ (period 1991 - 1999) as reported by Zhang et al. (2002) and Zhao et al. (2012), respectively, for different sites within the Lake Okeechobee watershed. The highest runoff values were also characterized by the lowest percolation rates due to the specific soil characteristics. Indeed, sandy spodosols, the predominant type of soil in the basin, is a poorly drained soil (Bottcher et al., 1995) that features surface water runoff as the primary flow pathway for TP transport to streams (Campbell et al., 1995). WAM simulation results indicated that the average flow leaving the sub-basin was around $3.68 \mathrm{~m}^{3} \mathrm{~s}^{-1}$ for the simulation period from $2002-2009$. A similar discharge value obtained from the SFWMD’s DBHYDRO database of $3.46 \mathrm{~m}^{3} \mathrm{~s}^{-1}$ was calculated at the S-191 structure for the same time period (SFWMD, 2013).

Phosphorus loads by land use

The TP loadings obtained from the WAM model for the major land use types within the S-191 sub-basin are summarized in Table 3-1. The TP loads generated at the farm level, at the nearby streams, and at the outlet of this sub-basin from all sources within the sub-basin were estimated at 106.4, 91, and 85 mtons $\mathrm{P} \mathrm{yr}^{-1}$, respectively. The TP loading leaving the sub-basin obtained with the WAM model is comparable to the monitored data at the S-191 structure of 72.8 mtons $\mathrm{P} \mathrm{yr}^{-1}$ for the same simulation time period. It is worth 
mentioning that although the S-191 sub-basin area represents only 3.5\% (48,470 ha) of the Lake Okeechobee watershed drainage area, it contributed 81\% (85 mtons $\mathrm{P} \mathrm{yr}^{-1}$ ) of the Lake TMDL (Zhang and Sharfstein, 2013). Moreover, the TP loads exceeded about five times the tributary TMDL set for this sub-basin at 19 mtons $\mathrm{P} \mathrm{yr}^{-1}$ (USEPA, 2008) during this 7-year period.

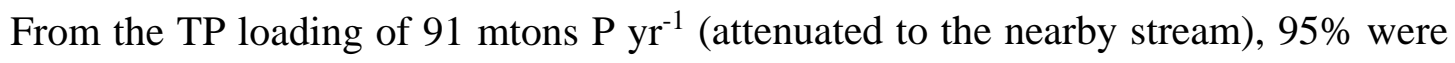
attributed to agriculture sources and $1.2 \%$ to urban areas, accounting for a combined TP load of 87.9 mtons $\mathrm{P} \mathrm{yr}^{-1}$ from non-point and point sources (Table 3-1). The remaining $3.4 \%$ of the TP load was attributed to natural areas. TP levels in surface water runoff are associated with the land use and land management practices within the sub-basin (Hiscock et al., 2003). Improved pastures represented the major land use type (56.5\%)

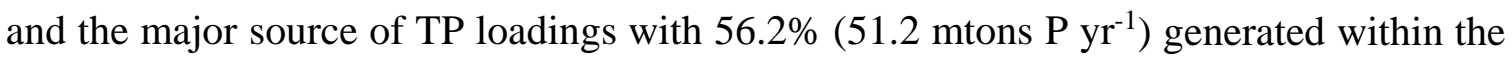
sub-basin. Dairy farms also represented a disproportionately large source of TP loadings, contributing 22.6\% (20.5 mtons $\mathrm{P} \mathrm{yr}^{-1}$ ) of the total TP loadings, although they represented only $4.6 \%$ of the total area. Other studies have also identified dairies as the primary TP source within the northern Lake Okeechobee watershed (Bottcher et al., 1995).

TP fluxes at the farm level are also reported in Table 3-1 for several land uses. Dairy, ornamental, and sod land use types presented the highest TP loading per hectare with 10.5, 9.0, and $6.5 \mathrm{~kg} \mathrm{ha}^{-1} \mathrm{yr}^{-1}$, respectively. The same range of values was found in other studies reporting TP in runoff of 3.4, 2.4, and $6.6 \mathrm{~kg} \mathrm{ha}^{-1} \mathrm{yr}^{-1}$, respectively, for the same land uses (SFWMD, 2010). In addition, Campbell et al. (1995) and Rechcigl and Bottcher (1995) reported average TP losses in surface water runoff of $1.6 \mathrm{~kg} \mathrm{ha}^{-1} \mathrm{yr}^{-1}$ and of $0.7 \mathrm{~kg} \mathrm{ha}^{-1} \mathrm{yr}^{-1}$, respectively from improved and unimproved pastures located in Lake 
Okeechobee watershed. These TP flux values were similar to the values estimated here with WAM and presented in Table 3-1. They are 2.2 and $0.7 \mathrm{~kg} \mathrm{ha}^{-1} \mathrm{yr}^{-1}$ for improved and unimproved pastures, respectively. Other studies conducted on different watersheds also reported comparable average TP loads in runoff. For instance, Zhang et al. (2012) estimated TP loads from improved pastures, row crop, and urban sources for watersheds in the state of Michigan at $0.95,0.6$, and $0.3 \mathrm{~kg} \mathrm{ha}^{-1} \mathrm{yr}^{-1}$, respectively. However, it is worth noticing that TP loads are greatly influenced by the hydrology, geology, and land and soil site conditions, affecting local loading contributions by land use from watersheds located in different geographic regions (Scott et al., 2011). Thus, it is important to emphasize that the values reported above corresponded to TP loads from different watersheds (Zhang et al., 2012) or from a different time period (Campbell et al., 1995; Rechcigl and Bottcher, 1995; SFWMD, 2010).

\section{Phosphorus attenuation}

The TP loads un-attenuated (at the farm level) and attenuated (reaching the nearby stream network once overland attenuation has been accounted for) are illustrated in Figs. 3-2a and 3-2b, respectively. Annual TP loading rates at the farm level averaged $2.2 \mathrm{~kg}$ $\mathrm{ha}^{-1} \mathrm{yr}^{-1}$ (Table 3-1), whereas attenuated TP loading rates to the nearby stream averaged $1.9 \mathrm{~kg} \mathrm{ha}^{-1} \mathrm{yr}^{-1}$. The major attenuation was observed in areas where features such as wetlands were present along the flow pathway. The actual TP loading, from each stream catchment area, reaching the sub-basin outlet was obtained using the in-stream attenuation algorithm developed in the present study. Fig. 3-2c illustrates the TP loading contribution from each source cell to the sub-basin outlet after stream attenuation factors have been accounted for. The annual TP loading rate to the sub-basin outlet averaged 1.7 
$\mathrm{kg} \mathrm{ha}^{-1} \mathrm{yr}^{-1}$, which is comparable to the average unit TP load to the Lake reported by Zhang et al. (2002) of $2.0 \mathrm{~kg} \mathrm{ha}^{-1} \mathrm{yr}^{-1}$ (from 1991 - 1999). When comparing the TP loading spatial distribution at the farm level (Fig. 3-2a) to the one attenuated to the outlet (Fig. 3-2c), the major changes occurred at the zones most distant from the sub-basin outlet (north and west of the sub-basin). Moreover, when comparing the two figures, it is worth noticing that the areas with high TP loadings (or hotspots) remain unchanged.

Fig. 3-3 represents the average attenuation factors classified by zones with different assimilation conditions. The calculated attenuation factors represented the percent of load assimilated by physical, chemical, and biological factors through the stream network, thus reducing the load reaching the Lake (Reddy et al., 1999). These factors depended mainly on the stream velocity, rate of nutrient exchange between the water column and sediments, and the distance to the sub-basin outlet. Results indicated that areas closer to the outlet yielded an attenuation factor of $1 \%$, whereas areas further away yielded an attenuation factor of $13 \%$. This means that $13 \%$ of the TP loadings from a source located in zone 6 (Fig. 3-3) will be assimilated or retained in the sub-basin through natural processes, and the remaining load will reach the outlet to Lake Okeechobee (assuming no phosphorus assimilation from the sub-basin outlet to the Lake). Previous studies have estimated higher percentage of TP attenuated through the transport system. For instance, Zhang et al. (2002) reported that $53.2 \%$ of TP was assimilated in the Lake Okeechobee watershed; additionally, SFWMD (2010) estimated a 33.2\% TP assimilation for Taylor Creek/Nubbin Slough sub-watershed. However, these percentages represented larger areas and considered overland and stream attenuation rates. The SWET (2008) report indicated TP assimilation rates for Lake Okeechobee watershed of 20 to $50 \%$ for 
upland overland flow and small streams, whereas lower assimilation rates of 2 to $20 \%$ were reported for canals and stream conveyances systems, agreeing with the attenuation factors represented here.

The calculated attenuation factors were then used to estimate the delivery trading ratios (TRs) following Supplemental Equation (3-S3). TRs lower than one (Supplemental Table 3-S5) are applied when a seller source is located downstream of the buyer source. For example, a source, located in zone 3, buying credits from a seller located in zone 2 would have to apply a TR of 0.98, as indicated in Supplemental Table 3-S5. In contrast, TRs greater than one were obtained when the seller source was located upstream of the buyer's location. Other trading programs also developed geographically-based trading ratios to equalize the loading discharged from sources at different locations from the basin outlet. For instance, delivery trading ratios for the Long Island Sound Total Nitrogen Credit Exchange program (CT, USA) ranged from 0.14 - 1 based on the location (CTDEP, 2010).

The TP loads attenuated to the nearby stream from each land use were aggregated per zone (listed in Supplemental Table 3-S6) and were then used as input data for the economic modeling methodology, as illustrated in Supplemental Fig. 3-S1.

\subsubsection{Economic modeling}

Cap and allocations

In water quality trading programs, the cap is generally defined based on a watershed mandatory goal for a particular pollutant, commonly known as the TMDL. For instance, the goal of the Pennsylvania Water Quality Trading Program was based on phosphorus, nitrogen, and sediment TMDLs previously established for the Chesapeake Bay (Branosky 
et al., 2011). In other trading programs, such as in the case of Neuse River Basin, a preset percent load reduction was used to define the goal of the program (Hamstead and BenDor, 2010). In the present study, the cap of the TP credit trading program for the S191 sub-basin could be calculated based on: 1) Lake Okeechobee TMDL of 105 mtons $\mathrm{yr}^{-1}$, and 2) Lake Okeechobee tributary TMDL. At the S-191 sub-basin level those numbers could be translated to 4.6 mtons $\mathrm{P} \mathrm{yr}^{-1}$ (flow proportionality) and 19 mtons $\mathrm{P} \mathrm{yr}^{-}$ ${ }^{1}$, which are necessary caps to meet Lake Okeechobee and the tributary TMDLs, respectively. Since WAM results indicated that 85 mtons $\mathrm{yr}^{-1}$ of TP were discharged from this sub-basin (from 2002 - 2009), this means that a respective 95\% and 78\% TP load reductions would be required to achieve the two possible caps presented above. The full implementation of advanced alternative BMPs across the sub-basin would not achieve the TP reduction needed for those two caps. Therefore, source control strategies cannot rely exclusively on BMPs to reduce TP loads in order to achieve the Lake Okeechobee TMDL or its tributary TMDL. An integrated approach encompassing different TP reduction projects, such as water quality treatment, water storage, wetland restoration, and nutrient trading among others, should be implemented in the sub-basin.

The costs resulting from implementing a Command-and-Control or a Least-Cost Abatement scenario to achieve different TP loading caps (set at the nearby stream levels), and the corresponding cost savings are illustrated in Fig. 3-4a. Cost savings ranged from $1 \%$ to $63 \%$, representing two extreme cases. The highest cost savings corresponded to a TP load of $2.3 \mathrm{~kg} \mathrm{ha}^{-1} \mathrm{yr}^{-1}$. The lowest cost savings were obtained when setting a TP load target at 30.8 mtons $\mathrm{yr}^{-1}$, leading to the implementation of advanced BMPs on all land use parcel sites. A TP load target of $1.6 \mathrm{~kg} \mathrm{ha}^{-1} \mathrm{yr}^{-1}$ (corresponding to a 30\% load reduction at 
the zone level or at the nearby stream) reflected the most cost-effective situation, achieving high cost savings (inflection point of the curves) of 31\% (\$1.5 million per year) when comparing the Least-Cost Abatement scenario to a Command-and-Control approach (Fig. 3-4a). This TP reduction target of 30\% at the zone level represented a cap

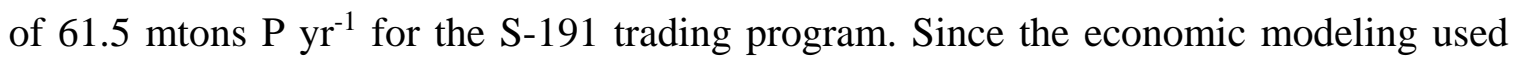
the TP loads from the potential trading sources (agricultural and urban land uses), a total

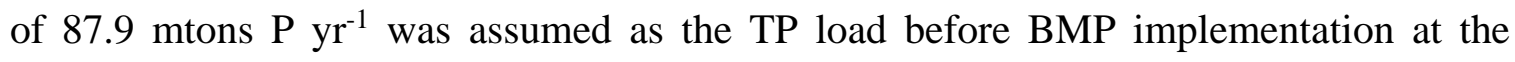
nearby stream level. The zone level cap of 61.5 mtons $\mathrm{P} \mathrm{yr}^{-1}$ was equivalent to 57.1 mtons $\mathrm{P} \mathrm{yr}^{-1}$ at the sub-basin outlet after phosphorus attenuation was considered for the entire basin. A higher percentage of TP reduction could be set as the cap of this trading program; however, as illustrated in Fig. 3-4a, this implies higher pollution abatement costs, and therefore lower cost savings, when comparing the Least-Cost Abatement scenario to a Command-and-Control approach.

The individual allocation was determined by uniformly distributing the cap among the potential trading sources. The resulted uniform allocation was set at $1.6 \mathrm{~kg} \mathrm{ha}^{-1} \mathrm{yr}^{-1}$, corresponding to the maximum TP load rate allowed to be discharged at each zone from the different land use types. Other methods exist for setting the allocation; however, almost every method presents some inequities. For example, the cap can be distributed equally among all existing sources or proportionally to the current loadings. The problem with the former method is that it does not consider that sources within the sub-basin greatly differ in size and their discharged load. Allocations based on load reduction by a fixed percentage might be perceived equitable. However, it does not recognize previous efforts and investments to implement technologies in order to reduce emissions (Field 
and Field, 2006). The approach selected in the present study to define allocation loads ensured a measurable cap and was proportional to the source size.

The Command-and-Control and the Least-Cost Abatement Scenarios

- BMP optimization

Under the Command-and-Control approach, the best available technology or BMP for each land use type and zone was selected in order to meet individual TP load allocations (Supplemental Fig. 3-S2a). Some land use types, such as citrus, unimproved pastures, rangelands and wooded pastures, and urban areas did not require application of any BMPs, because they were already in compliance with their individual allocation loads. In contrast, dairies, field crops, ornamentals, and soy land use types needed respectively up to $88 \%, 70 \%, 86 \%$, and $73 \%$ of TP reduction to reach their individual load allocations. Therefore, the most advanced and expensive type of BMP - type III - (a combination of owner, typical, and alternative BMPs) had to be implemented for these land uses. On the other hand, under the Least-Cost Abatement approach, the selection of the BMP types was optimized in order to achieve the lowest cost while reaching the overall TP reduction target for the S-191 sub-basin (Supplemental Fig. 3-S2b). In this case, BMP type I (owner type) was selected to be implemented on citrus and urban areas, reaching a TP load reduction of 5\% and 12\%, respectively, at no cost (Supplemental Tables 3-S2 and 3S3). Moreover, a BMP type I was selected to be implemented on most of dairy farms, instead of the BMP type III needed under the conventional approach, thus decreasing the annual investment from $\$ 3.3$ million to $\$ 0.4$ million for this land use type within the subbasin. 


\section{- TP loads after BMP implementation}

The total TP load from agricultural and urban sources reaching the nearby stream and the sub-basin outlet following the implementation of BMPs was 52.2 and 48.5 mtons $\mathrm{P}$ $\mathrm{yr}^{-1}$, respectively, under both scenarios. This is equivalent to a TP reduction of $41 \%$ higher than the preset TP reduction target of $30 \%$, because of the discrete nature of the BMP data used in this study (Supplemental Table 3-S3). In other words, in some cases, the required percentage load reduction was lower than the percentage efficiency of the BMP needed to be applied - thus leading to an overall higher TP reduction.

Potential land use buyers were identified whenever TP loadings under the Least-Cost Abatement were above the Command-and-Control TP loadings; otherwise the land uses were identified as potential sellers (Supplemental Table 3-S7). The difference in the loads under both scenarios reflected the number of credits available to sell or the number of credits needed to buy (defined as the difference in TP load amount in kg). For example, citrus, improved pastures, and urban land uses could potentially sell 144, 11,632, and 57 TP credits, respectively. Alternatively, dairies, ornamentals, row crops, and sod land uses would need to purchase 11,000, 320, 85, and 418 TP credits, respectively. These results suggest that 11,832 credits were available for sell and for purchase to offset TP loadings in the entire sub-basin. Therefore, enough supply of TP credits existed in this sub-basin to offset the demand of potential trading buyers.

- Credit price

The credit price was obtained from the Least-Cost Abatement scenario while deriving the marginal abatement costs for all trading sources to meet a specific TP load as illustrated in Fig. 3-4b. This aggregate supply curve indicates the price that trading 
sources would be willing to pay to reduce the basin TP loads to different levels. In the

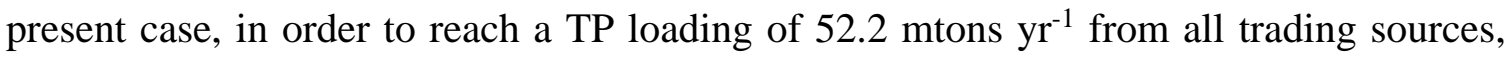
the credit price was around $\$ 179$. A similar methodology to calculate the marginal costs was used by Paniccia (2002) resulting in credit prices up to $\$ 12,000$, when developing a trading program among metal wastewater treatment plants. Point to non-point nutrient trading programs, located in different watersheds within the United States, such as in the Lower St. Johns River (FL), Chesapeake Bay (PA), and Great Miami River (OH) watersheds, reported credit prices of $\$ 151.8, \$ 22$, and $\$ 28.2$, respectively, for TP credits exchanged (Corrales et al., 2013). It is worth noticing that marginal abatement cost curves represent the abatement cost for a single point in time and hence are subject to inter-temporal dynamics. This means that marginal abatement costs depend on abatement actions realized in earlier time periods and expectations about later time periods (Kesicki, 2011).

- Credits exchanged and cost savings

Tables 3-2 and 3-3 represent the list of potential buyers and sellers that were identified in this sub-basin, as well as their respective cost savings. In total, 10 buyers and 14 sellers were identified. The total number of TP credits exchanged was 9,579, corresponding to $81 \%$ of the credits available for trading. Dairy farms were the major buyer source, purchasing in total 8,879 credits, whereas improved pastures were the most important seller source, selling in total 9,378 credits. As illustrated in Table 3-2, the costs of BMP implementation under the Command-and-Control approach for all buyers was 1.5 times higher than the costs obtained under a trading scenario approach, representing an annual cost savings of $\$ 966,443$. Although sellers incurred an additional cost of $\$ 1.4$ 
million by switching from the Command-and-Control scenario to the Least-Cost Abatement scenario, they also sold $\$ 1.7$ million worth of credits, representing an annual cost savings of $\$ 376,022$. A transaction fee of $10 \%$ was added to the credit cost for buyer sources, in order to consider the cost associated with research, negotiation, approval, monitoring, and finding trading partners (Stavins, 2003). Transaction cost estimates for market-based or conservation programs ranged between $10 \%$ and 50\%. Galik et al. (2012) assessed transactions cost for the U.S forest carbon offset program as 25\% per credit sold. Heimlich (2005) estimated transaction cost factors of $10 \%$ to $15 \%$ for Conservation Reserve Programs (CRP). Fang et al. (2005) estimated a 35\% transaction cost for the Minnesota River Basin nutrient trading program. Knowing that high transaction costs could jeopardize the trading activity (Corrales et al., 2013), a low 10\% was adopted as the transaction cost in order to retain the cost effectiveness while still meeting environmental benefits.

Overall, the total cost savings of a credit trading program, obtained under the current scenario to reduce TP loadings in the S-191 sub-basin, were 27\% (\$1.3 million per year) in comparison to a conventional Command-and-Control approach. Other studies have estimated cost savings about $36 \%$ and $74 \%$ for trades between point and non-point sources over traditional Command-and-Control approaches, respectively for the Chesapeake Bay (Van Houtven et al., 2012) and the Great Miami River watershed (Kieser \& Associates, 2004). However, it is important to emphasize that cost savings vary substantially depending on different factors, such as 1) the type of trading allowed in the program (i.e., only between point sources, between point and non-point sources, or between non-point sources), 2) the geographic region - the larger the area where trading 
is allowed, the wider range of trading opportunities, and therefore the larger cost savings - (Van Houtven et al., 2012), and 3) the technology and management practices available for nutrient reduction for diverse sources in the watershed.

\subsection{Conclusions}

The economic and environmental benefits of implementing a phosphorus credit trading program were assessed for the S-191 sub-basin located in the Lake Okeechobee watershed. A water quality model was linked to an economic model to assess the feasibility of a phosphorus credit trading program in this agricultural sub-basin. The hydrology and water quality model was used to quantify the effects of rainfall, land use type, soil characteristics, and management practices on the phosphorus loadings generated at the farm level, attenuated to the nearby stream, and attenuated to the subbasin outlet. The most cost effective cap of $30 \%$ TP reduction (equivalent to a total loading of 61.5 mtons $\mathrm{P} \mathrm{yr}^{-1}$ at the zone level) was set and two abatement approaches (Least-Cost Abatement and Command-and-Control) were compared in this study.

The Least-Cost Abatement approach provided the optimal combination of management practices that minimized the cost to achieve the cap in the S-191 sub-basin. When comparing the two approaches, the estimated potential cost savings were of $27 \%$ (\$1.3 million per year), based on an optimal credit price of $\$ 179$. In this study, dairies (major buyer), ornamentals, and sod land use types were identified as potential credit buyers, whereas citrus, improved pastures (major seller), and urban land uses were identified as potential credit sellers. The results of the trading scenario also suggested an adequate supply of TP credits to meet the buyers demand. Almost $81 \%$ of the TP credits 
available for trading (corresponding to 9,579 TP credits) were exchanged. It is worth emphasizing that the cost savings achieved are greatly influenced by site-specific factors such as the type of pollution sources, the geographical location, BMPs nutrient removal efficiencies and cost data, etc. Expanding the geographic scope of trading to the entire Taylor Creek / Nubbin Slough sub-watershed or to the whole Lake Okeechobee watershed, would lead to a different trading scenario with different delivery trading ratios, and potentially higher cost savings. However, the methodology presented here can be used and easily modified to incorporate other forms of trading (e.g., point-to-point trading), other contaminants, or other technologies and management practices.

Implementation of a phosphorus trading program in the S-191 sub-basin should be considered as part of an integrated approach to reduce phosphorus loadings in the Lake Okeechobee watershed.

\subsection{Acknowledgments}

The authors thank the Bachelor Foundation, the Darden Foundation, and Lacoste for their financial support.

\subsection{References}

Bottcher, A.B., Tremwel, T.K., Campbell, K.L., 1995. Best management practices for water quality improvement in the Lake Okeechobee watershed. Ecol. Eng. 5, 341356.

Branosky, E., Jones, C.Y., Selman, M., 2011. Comparison tables of state nutrient trading programs in the Chesapeake Bay Watershed. World Resources Institute, Washington, D.C.

Campbell, K.L., Capece, J.C., Tremwel, T.K., 1995. Surface /subsurface hydrology and phosphorus transport in the Kissimmee River Basin, Florida. Ecol. Eng. 5, 301-330. 
Chebud, Y., Naja, G., Rivero, R., 2011. Phosphorus run-off watershed assessment: From monitoring to modeling through a case study. J. Environ. Monitor. 13, 66-73.

Corrales, J., Naja, G.M., Miralles-Wilhelm, F., Bhat, M.G., 2013. Water quality trading programs towards solving environmental pollution problems. Irrig. and Drain. 62 (Suppl. 2), 72-92.

CTDEP, 2010. Connecticut's nitrogen credit exchange - An incentive-based water quality trading program. Connecticut Department of Environmental Protection. Bureau of Water Protection and Land Reuse, Hartford, CT.

Fang F., Easter, K.W., Brezonik, P.L., 2005. Point-nonpoint source water quality trading: A case study in the Minnesota River Basin. J. Am. Water Resour. As. 41, 645-658.

FDACS, 2011. Report on the implementation of agricultural best management practices. Florida Department of Agriculture and Consumer Services. Office of Agricultural Water Policy, Tallahassee, FL.

FDEP, 2001. Total maximum daily load for total phosphorus Lake Okeechobee. Florida Department of Environmental Protection, West Palm Beach, FL.

Field, B.C., Field, M.K., 2006. Environmental economics: An introduction, fourth ed. McGraw Hill-Irwin, New York, NY.

Gale, J.A., Line, D.E., Osmond, D.L., Coffey, S.W., Spooner, J., Arnold, J.A., Hoban, T.J., Wimberley, R.C., 1993. Evaluation of the experimental rural clean water program. National Water Quality Evaluation Project, NCSU Water Quality Group, Biological and Agricultural Engineering Department, North Carolina State University, Raleigh, NC, EPA-841-R-93-005.

Galik, C.S., Cooley, D.M., Baker, J., 2012. Analysis of the production and transaction costs of forest carbon offset projects in the USA, J. Environ. Manage. 112, 128-136.

Hamstead, Z.A., BenDor, T.K., 2010. Over compliance in water quality trading programs: Findings from a qualitative case study in North Carolina. Environment and Planning C: Government and Policy 28.

HDR, 2004. Hydrologic / water quality characterization of the watershed - WAM without projects. Watershed assessment report submitted as part of the Comprehensive Everglades Restoration Plan (CERP). South Florida Water Management District, West Palm Beach, FL.

Heimlich, R., 2005. The policy-related transaction costs of land conservation in the U.S.: Evolution and comparison between programs. Presented at the OECD workshop on policy-related transaction costs, Paris, France. 
Hiscock, J.G., Thourot, C.S., Zhang, J., 2003. Phosphorus budget-land use relationships for the Northern Lake Okeechobee Watershed, Florida. Ecol. Eng. 21, 63-74.

Kardos, J.S., Obropta, C.C., 2011. Water quality model uncertainty analysis of a pointpoint source phosphorus trading program. J. Am. Water Resour. As. 47, 1317-1337.

Kesicki, F., 2011. Marginal abatement cost curves for policy making - expert-based vs. model-derived curves. UCL Energy Institute, University College London, London, United Kingdom.

Kieser \& Associates, 2004. Preliminary economic analysis of water quality trading opportunities in the Great Miami River Watershed, Ohio. Kalamazoo, MI, p. 15.

King, D., Kuch, P., 2003. Will nutrient credit trading ever work? An assessment of supply and demand problems and institutional obstacles. Environmental Law Reporter 33, 10352-10368.

Mariola, M.J., 2009. Are markets the solution to water pollution? A sociological investigation of water quality trading. Graduate Program in Rural Sociology. Ohio State University, Columbus, $\mathrm{OH}$.

McCormick, P., James, R.T., Zhang, J., 2011. Chapter 10. Lake Okeechobee protection program-state of the lake and watershed. 2010 South Florida Environmental ReportVolume I. South Florida Water Management District, West Palm Beach, FL.

Paniccia, J., 2002. A Permitting system for metals/wastewater producing industrial users under the pretreatment trading approach. Economic Department. Florida International University, Miami, FL.

Rechcigl, J.E., Bottcher, A.B., 1995. Fate of phosphorus on Bahia grass (Paspalum notatum) pastures. Ecol. Eng. 5, 247-259.

Reddy, K.R., Kadlec, R.H., Flaig, E., Gale, P.M., 1999. Phosphorus retention in streams and wetlands: A review. Crit. Rev. Env. Sci. Tec. 29, 83-143.

Schleich, J., White, D., 1997. Cost minimization of nutrient reduction in watershed management using linear programming. J. Am. Water Resour. As. 33, 135-142.

Schwartz, S.S., 2010. Optimization and decision heuristics for Chesapeake Bay nutrient reduction strategies. Environ. Model. Assess. 15, 345-359.

Scott, W.A., Brakebill, J.W., Blomquist, J.D., 2011. Sources, fate, and transport of nitrogen and phosphorus in the Chesapeake Bay Watershed: An empirical model: 
U.S. Geological Survey Scientific Investigation Report 2001-5167. U.S. Department of Interior and U.S. Geological Survey, Reston, VA.

SFWMD, 2010. Nutrient budget analysis for the Lake Okeechobee Watershed. Report prepared by the South Florida Water Management District and the HDR group, West Palm Beach, FL.

SFWMD, 2013. South Florida Water Management District DBHYDRO database. South Florida Water Management District, West Palm Beach, FL. http://www.sfwmd.gov/dbhydroplsql/show_dbkey_info.main_menu (accessed Jun 2012).

SFWMD, FDEP, FDACS, 2011. Lake Okeechobee protection plan. final update report. South Florida Water Management District, West Palm Beach, FL; Florida Department of Environmental Protection, Tallahassee, FL; and Florida Department of Agriculture and Consumer Services, Tallahassee, FL., p. 463.

Stavins, R., 2003. Market-based environmental policies: What can we learn from U.S. experience (and related research)? Resources for the Future, Washington, D.C., p. 28.

SWET, 2006. Letter report entitled: Phosphorus reduction performance and implementation costs under BMPs and technologies in the Lake Okeechobee protection plan area. Soil and Water Engineering \& Technology Inc., Gainesville, FL.

SWET, 2008. Final report: Nutrient loading rates, reduction factors and implementation costs associated with BMPs and technologies. Soil and Water Engineering \& Technology Inc., Gainesville, FL.

SWET, 2011a. Watershed Assessment Model documentation. Soil and Water Engineering \& Technology, Inc., Gainesville, FL.

SWET, 2011b. Watershed Assessment Model documentation and validation. Task 4 Final Report submitted to the South Florida Water Management District. Soil and Water Engineering \& Technology, Inc., Gainesville, FL.

SWET, JGH Engineering, 2007. Technical assistance in review and analysis of existing data for evaluation of legacy phosphorus in the Lake Okeechobee Watershed. Task 2 Final Report submitted to the South Florida Water Management District. Soil and Water Engineering \& Technology, Inc., Gainesville, FL.

USDA, 2013. Geo-spatial data gateway. U.S. Department of Agriculture. Natural Resources Conservation Service, Washington, D.C. 
http://datagateway.nrcs.usda.gov/GDGOrder.aspx?order=QuickState (accessed Jun, 2012).

USEPA, 2008. Final Total Maximum Daily Load (TMDL) for biochemical oxygen demand, dissolved oxygen, and nutrients in the Lake Okeechobee tributaries. U.S. Environmental Protection Agency, Atlanta, GA.

Van Houtven, G., Loomis, R., Baker, J., Beach, R., Casey, S., 2012. Nutrient credit trading for the Chesapeake Bay: An economic study. RTI International, Research Triangle Park, NC.

Zhang, J., Ray S.A.F., Steinman, A., 2002. Potential phosphorus load reductions under the Lake Okeechobee regulatory program. J. Am. Water Resour. As. 38, 16131624.

Zhang, J., Sharfstein, B., 2013. Chapter 8. Lake Okeechobee Watershed protection program. 2013 South Florida Environmental Report. South Florida Water Management District, West Palm Beach, FL.

Zhang, T., Soranno, P.A., Cheruvelil, K.S., Kramer, D.B., Bremigan, M.T., LigmannZielinska, A., 2012. Evaluating the effects of upstream lakes and wetlands on lake phosphorus concentrations using a spatially-explicit model. Landscape Ecol. 27, 1015-1030.

Zhao, H., Zhang, J., James, R.T., Laing, J., 2012. Application of MIKE SHE/MIKE11 model to structural BMPs in S191 basin, Florida. J. Environmental Informatics 19: 10-19. 


\subsection{Tables}

Table 3-1. Average annual Total Phosphorus (TP) load per land use type.

\begin{tabular}{|c|c|c|c|c|c|}
\hline Land Use & Area (ha) & $\begin{array}{l}\text { TP load at } \\
\text { the farm } \\
\text { level } \\
\text { (mtons } \mathbf{y r}^{-1} \text { ) }\end{array}$ & 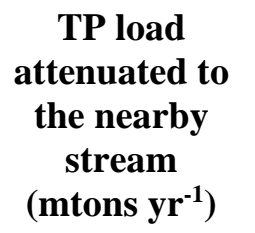 & $\begin{array}{c}\text { TP load } \\
\text { attenuated } \\
\text { to the sub- } \\
\text { basin outlet } \\
\text { (mtons yr-1) }\end{array}$ & $\begin{array}{l}\text { TP load flux at } \\
\text { the farm level } \\
\left(\mathrm{kg} \mathrm{ha}^{-1} \mathrm{yr}^{-1}\right)\end{array}$ \\
\hline Citrus & $1,415(2.9 \%)$ & 1.2 & $1.2(1.3 \%)$ & 1.1 & 0.9 \\
\hline Improved Pastures & $27,372(56.5 \%)$ & 59.2 & $51.2(56.2 \%)$ & 47.5 & 2.2 \\
\hline Unimproved Pastures & $1,571(3.2 \%)$ & 1.1 & $1(1.1 \%)$ & 1 & 0.7 \\
\hline Rangeland and Wooded Pastures & $201(0.4 \%)$ & 0.2 & $0.1(0.2 \%)$ & 0.1 & 0.8 \\
\hline Dairies & $2,210(4.6 \%)$ & 23.3 & $20.5(22.6 \%)$ & 19.5 & 10.5 \\
\hline Field Crop & $1,745(3.6 \%)$ & 10.3 & $8.5(9.3)$ & 8 & 5.9 \\
\hline Ornamentals & $222(0.5 \%)$ & 2 & $1.7(1.9 \%)$ & 1.6 & 9.0 \\
\hline Row Crop & $214(0.4 \%)$ & 0.5 & $0.5(0.5 \%)$ & 0.4 & 2.4 \\
\hline Sod & $373(0.8 \%)$ & 2.4 & $2(2.2 \%)$ & 1.9 & 6.5 \\
\hline Urban & $2,423(5 \%)$ & 2.1 & $1.1(1.2 \%)$ & 1.1 & 0.9 \\
\hline Natural Areas ${ }^{\mathrm{a}}$ & $10,724(22.1 \%)$ & 4.0 & $3.1(3.4 \%)$ & 2.9 & 0.4 \\
\hline Total & $48,470(100 \%)$ & 106.4 & $91(100 \%)$ & 85 & 2.2 \\
\hline
\end{tabular}

${ }^{a}$ TP loadings from natural areas were not considered in the credit trading program assessment. 
Table 3-2. Summary of credits bought and costs for the buyer sources.

\begin{tabular}{|c|c|c|c|c|c|c|c|}
\hline ID & $\begin{array}{c}\text { Buyer/ } \\
\text { Zone }^{\mathrm{a}}\end{array}$ & Seller ID $^{\mathbf{b}}$ & $\begin{array}{l}c^{\prime} \\
(\$)^{\mathrm{c}}\end{array}$ & $\begin{array}{l}c^{\prime \prime} \\
(\$)^{d}\end{array}$ & $\begin{array}{l}\text { Credits } \\
\text { Bought }\end{array}$ & $\begin{array}{l}c^{\prime \prime \prime} \\
(\$)^{\mathrm{e}}\end{array}$ & $\begin{array}{l}\text { Cost savings } \\
(\$)^{f}\end{array}$ \\
\hline B1 & $\mathrm{D} / 1$ & S8, S9, S10, S11 & 766,780 & 2,997 & 2,883 & 567,679 & 196,104 \\
\hline B2 & $\mathrm{O} / 1$ & S3, S4, S5 & 12,904 & 4,322 & 42 & 8,194 & 388 \\
\hline B3 & $\mathrm{D} / 2$ & $\mathrm{~S} 11, \mathrm{~S} 12, \mathrm{~S} 13, \mathrm{~S} 14$ & $1,099,001$ & 4,296 & 2,503 & 492,907 & 601,799 \\
\hline B4 & $\mathrm{O} / 2$ & S5 & 12,289 & 4,116 & 32 & 6,398 & 1,776 \\
\hline B5 & $\mathrm{S} / 2$ & S5 & 117,545 & 30,007 & 413 & 81,349 & 6,188 \\
\hline B6 & $\mathrm{D} / 3$ & S5, S6, S7, S8 & 321,840 & 1,258 & 1,384 & 272,432 & 48,150 \\
\hline B7 & $\mathrm{O} / 3$ & S5 & 58,990 & 19,756 & 82 & 16,131 & 23,102 \\
\hline B8 & $\mathrm{O} / 4$ & S5 & 46,700 & 15,640 & 118 & 23,285 & 7,775 \\
\hline B9 & $\mathrm{D} / 5$ & S9 & 498,333 & 1,948 & 2,109 & 415,266 & 81,119 \\
\hline \multirow[t]{2}{*}{ B10 } & $\mathrm{S} / 6$ & $\mathrm{~S} 1, \mathrm{~S} 2$ & 2,466 & - & 12 & 2,422 & 44 \\
\hline & & & $2,936,847$ & 84,339 & 9,579 & $1,886,065$ & 966,443 \\
\hline
\end{tabular}

a (D), Dairies; (O), Ornamentals; (S) Sod.

${ }^{\mathrm{b}}$ Identification of the sellers (from Table 3-3) selling credits to the specific buyer.

${ }^{\mathrm{c}}$ Annual cost under the Command-and-Control approach.

${ }^{\mathrm{d}}$ Annual cost under the Least-Cost Abatement approach.

${ }^{\text {e }}$ Cost of the credits bought plus a $10 \%$ transaction fee.

${ }^{\mathrm{f}}$ Annual cost savings calculated following Supplemental Equation (3-S6). 
Table 3-3. Summary of credits sold and costs for the seller sources.

\begin{tabular}{|c|c|c|c|c|c|c|c|}
\hline ID & $\begin{array}{l}\text { Seller/ } \\
\text { Zone }^{\mathbf{a}}\end{array}$ & Buyer ID $^{\mathbf{b}}$ & $\begin{array}{l}c^{\prime} \\
(\$)^{c}\end{array}$ & $\begin{array}{l}c^{\prime \prime} \\
(\$)^{d}\end{array}$ & $\begin{array}{l}\text { Credits } \\
\text { Sold }\end{array}$ & $\begin{array}{l}c^{\prime \prime \prime} \\
(\$)^{\mathrm{e}}\end{array}$ & $\begin{array}{c}\text { Cost savings } \\
(\$)^{\mathrm{f}}\end{array}$ \\
\hline S1 & $\mathrm{U} / 1$ & B10 & - & - & 6 & 1,062 & 1,062 \\
\hline S2 & $\mathrm{C} / 2$ & B10 & - & - & 6 & 1,126 & 1,126 \\
\hline S3 & $\mathrm{U} / 2$ & B2 & - & - & 18 & 3,299 & 3,299 \\
\hline S4 & $\mathrm{C} / 3$ & B2 & - & - & 5 & 812 & 812 \\
\hline S5 & IP/ 3 & B2, B4, B5, B6, B7, B8 & 58,978 & 235,912 & 1,585 & 283,735 & 106,801 \\
\hline S6 & $\mathrm{U} / 3$ & B6 & - & - & 25 & 4,519 & 4,519 \\
\hline S7 & $\mathrm{C} / 4$ & B6 & - & - & 48 & 8,654 & 8,654 \\
\hline S8 & IP/ 4 & B1, B6 & 257,152 & 819,671 & 3,714 & 664,813 & 102,294 \\
\hline S9 & $\mathrm{U} / 4$ & B1, B9 & - & - & 4 & 774 & 774 \\
\hline S10 & $\mathrm{C} / 5$ & B1 & - & - & 38 & 6,759 & 6,759 \\
\hline S11 & IP/ 5 & B1, B3 & 50,990 & 650,119 & 4,079 & 730,167 & 131,037 \\
\hline S12 & $\mathrm{U} / 5$ & B3 & - & - & 1 & 150 & 150 \\
\hline S13 & $\mathrm{C} / 6$ & B3 & - & - & 47 & 8,371 & 8,371 \\
\hline \multirow[t]{2}{*}{ S14 } & $\mathrm{U} / 6$ & B3 & - & - & 2 & 363 & 363 \\
\hline & & & 367,119 & $1,705,702$ & 9,579 & $1,714,605$ & 376,022 \\
\hline
\end{tabular}

${ }^{\mathrm{a}}$ (U), Urban; (C), Citrus; (IP), Improved Pastures.

${ }^{\mathrm{b}}$ Identification of the buyer (from Table 3-2) purchasing credits from the specific seller.

${ }^{\mathrm{c}}$ Annual cost under the Command-and-Control approach.

${ }^{\mathrm{d}}$ Annual cost under the Least-Cost Abatement approach.

${ }^{\mathrm{e}}$ Cost of the credits sold.

${ }^{\mathrm{f}}$ Annual cost savings calculated following Supplemental Equation (3-S5). 


\subsection{Figures}

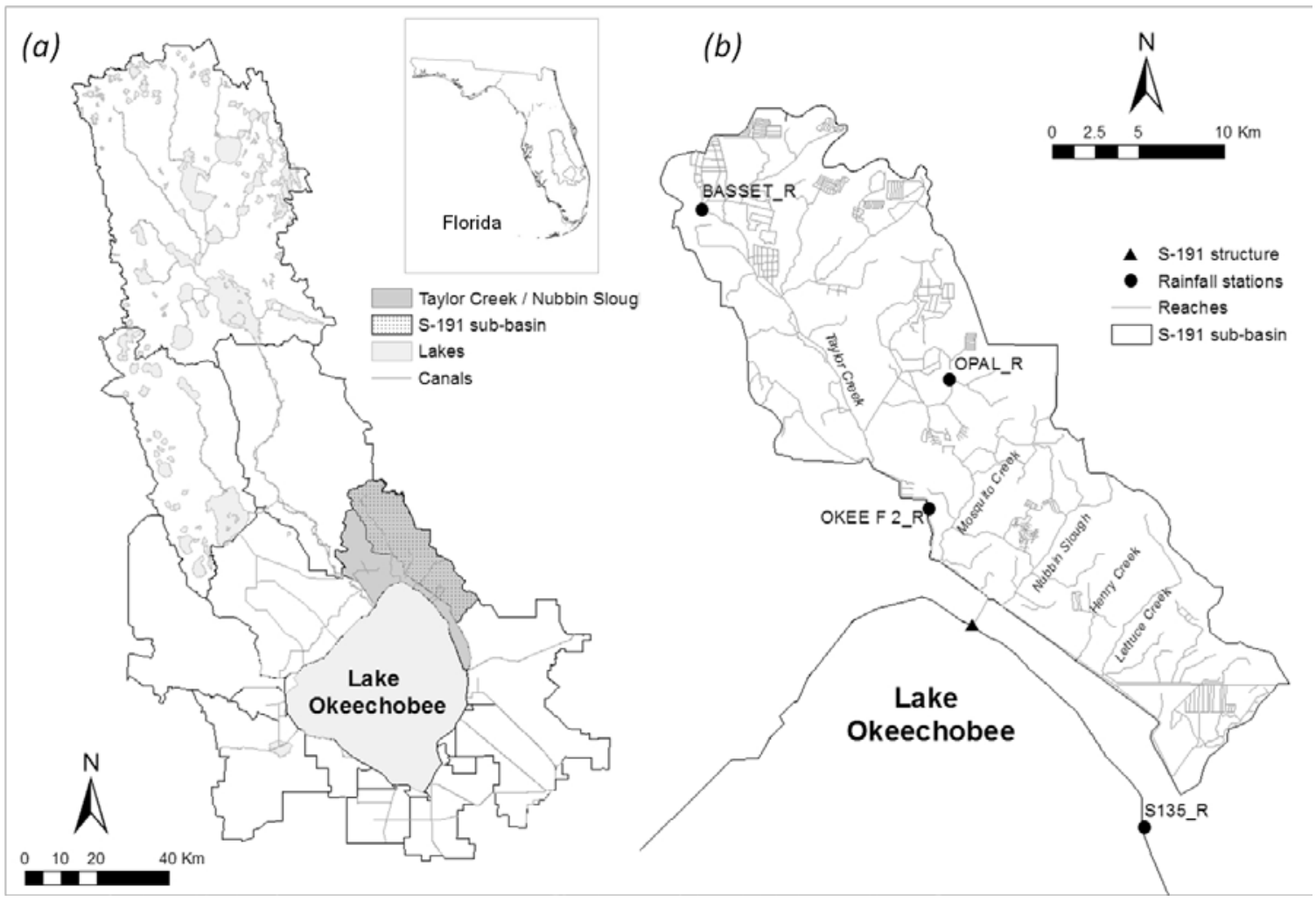

Figure 3-1. (a) Maps of Florida, Lake Okeechobee watershed, and S-191 sub-basin study area. (b) S-191 sub-basin hydrography and rainfall stations. 

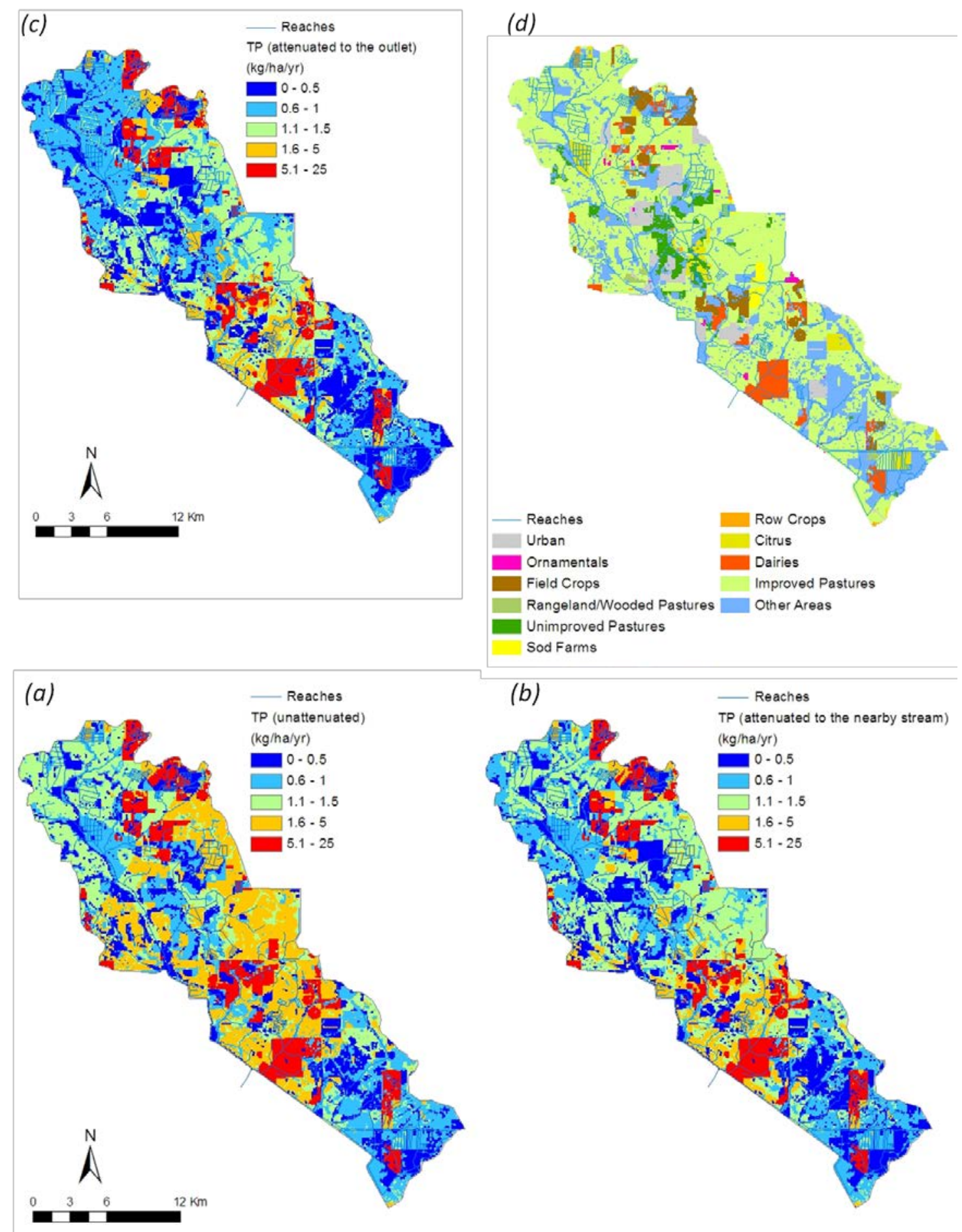

Figure 3-2. Total Phosphorus (TP) loading spatial distribution ( $\left.\mathrm{kg} \mathrm{ha}^{-1} \mathrm{yr}^{-1}\right)$ : (a) unattenuated at the farm level, (b) attenuated to the nearby stream, (c) attenuated to the subbasin outlet. (d) Land use classification in the S-191 sub-basin. 


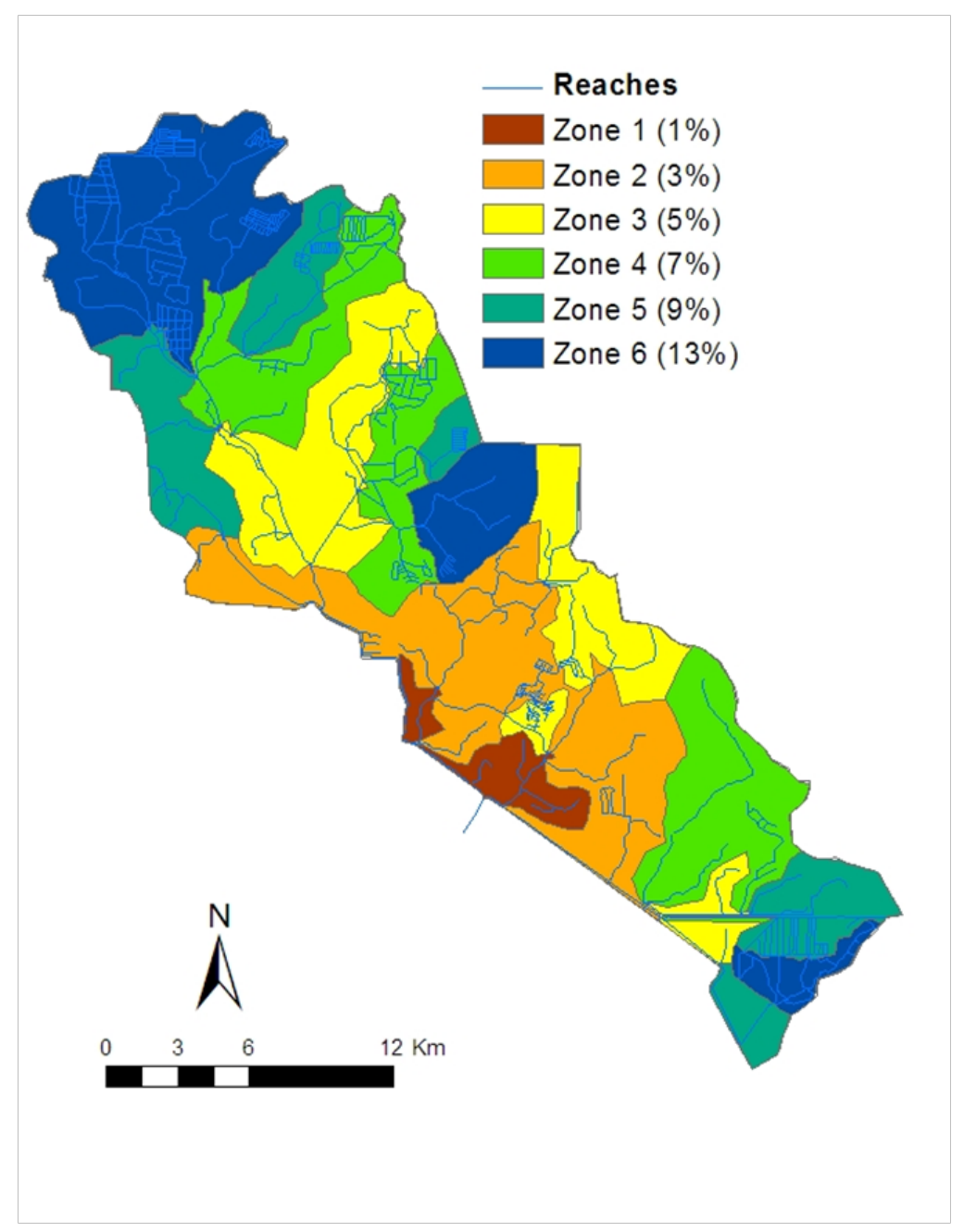

Figure 3-3. Zone classification of the phosphorus attenuation factors. 
(a)

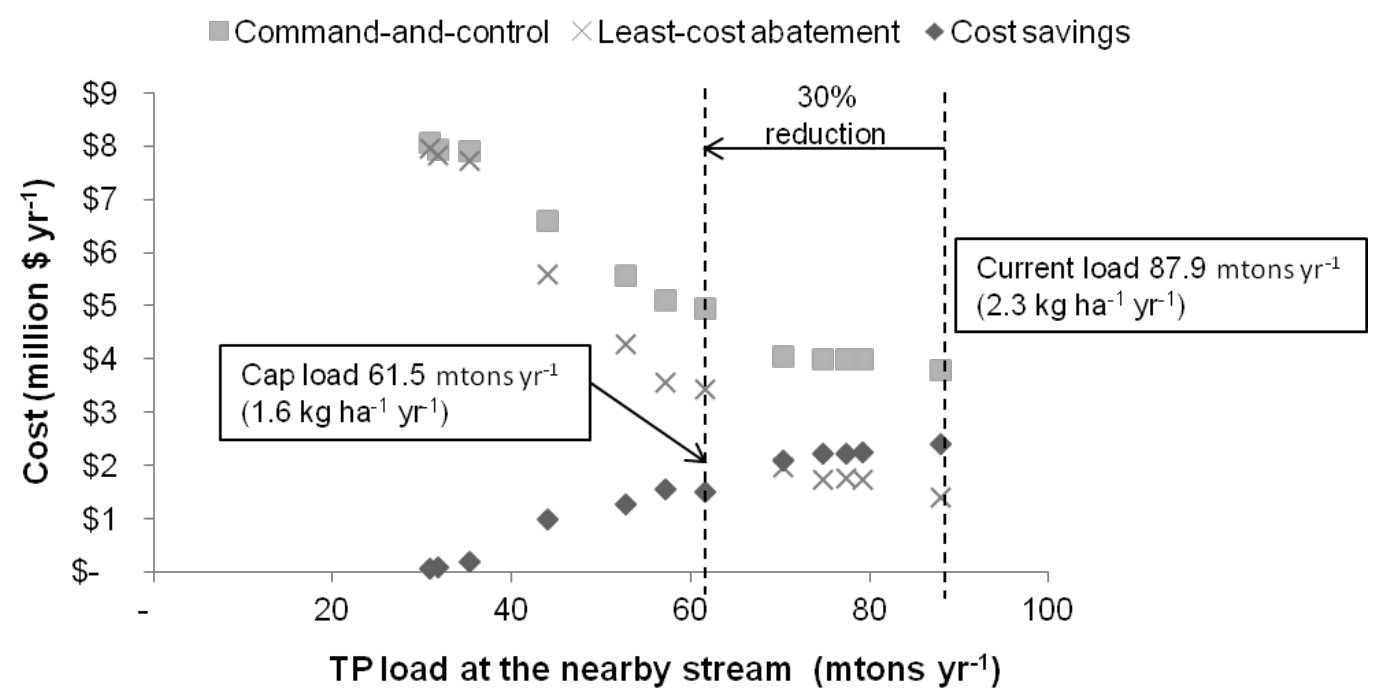

(b)

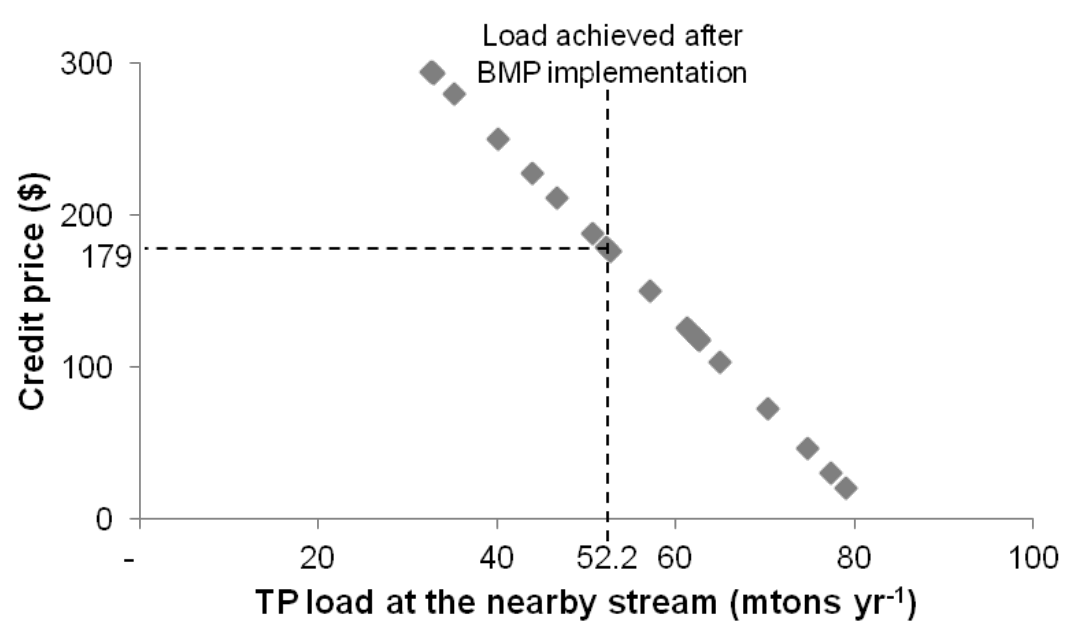

Figure 3-4. (a) Costs and cost savings (in million dollars per year) of achieving different TP loading caps at the zone level under a Command-and-Control approach and a LeastCost Abatement scenario. (b) Credit price (\$) determination. 


\subsection{Supplemental Information}

It includes details about the Watershed Assessment Model, the equimarginal cost principle, the marginal abatement cost, and the six steps for phosphorus trading analysis. It also includes Figs. 3-S1, 3-S2 and 3-S3, as well as Tables 3-S1, 3-S2, 3-S3, 3-S4, 3-S5, 3-S6 and 3-S7 as indicated in the text.

\subsubsection{Watershed assessment model (WAM)}

WAM model uses a cell-grid based system that overlays land use, soil, rain zone, and wastewater treatment zone input data to create a group of unique cells to be modeled using the most appropriate field-scale sub-model. The Basin Unique Cell Shell program (BUCSHELL) selects one of the three field-scale sub-models differing in their ability to deal with the specific and distinctive natural characteristics of land use and soil type. Well drained soils are generally simulated by the Groundwater Loading Effects of Agricultural Management Systems (GLEAMS) (Knisel, 1993). High water table soils are simulated using the Everglades Agricultural Area Model (EAAMOD) (SWET, 2008). Land use/soil combinations not handled by either GLEAMS or EAAMOD, such as wetlands, impervious urban areas, aquaculture, and mining operations are modeled using a special case module created specifically for WAM (SWET, 2011a). Each field-scale model calculates daily surface and groundwater flows and constituent concentrations leaving each source cell in the watershed. The flows and loads are then routed to the nearest stream within the Basin Land Area to Stream Routing sub-model (BLASROUTE). Water and constituents reaching the streams are then routed hydrodynamically through the stream network to the outlet while being attenuated based on features encountered along the way, such as wetlands or depressions, or based on the 
stream and structure types. WAM uses Thiessen polygons to create rainfall zones linked to daily rainfall records. The rainfall data, the driving force of the model, will determine how much runoff or groundwater percolation would originate at each source cell and then be routed to the nearest stream.

\subsubsection{Equimarginal cost principle and marginal abatement cost}

Theoretically, when there are multiple sources of a particular pollutant with differing marginal abatement cost, and if it is desired to achieve a given goal at the lowest possible cost, then emissions from various sources must be in accordance with the "equimarginal cost principle” (Field and Field, 2006). This economic principle, illustrated in Fig. 3-S3 depicting the Marginal Abatement Cost (MAC) curves of two hypothetical TP sources (A and B) with different abatement costs, is related to the fact that pollution sources use different management practices or technologies to control emissions. MAC curves act essentially as supply curves, showing the amount of load reduction that sources would achieve at different costs (Field and Field, 2006). The intersection of the two marginal abatement costs (Fig. 3-S3) is where economic efficiency, also known as the equimarginal cost principle, is met (Bockel et al., 2012). In other words, least-cost solutions for achieving a desired abatement level $\left(e^{*}\right)$ are only reached when marginal abatement cost of different pollution sources are equal (Field and Field, 2006). The MAC value $p^{*}$ is associated with the efficient abatement level $e^{*}$, and represents the credit price (or shadow price) that potential buyers or sellers will be willing to pay or sell for nutrient credits. For the source A, the total cost to attain the reduction level $e^{*}$ is denoted by the area $a$, whereas for source B the total cost is denoted by the area $b$. The efficient abatement level, $e^{*}$, shows that a source with a low abatement cost (Source B) should 
reduce more emissions than the high abatement cost source (Source A). A source will be willing to purchase credits if its marginal abatement cost is higher than the credit price, to save the difference in abatement cost. In contrast, a source will be willing to sell credits if its marginal abatement cost is lower than the credit price, because the revenue from the sale would cover the added abatement cost incurred to reduce additional emissions. In general, buyers in trading programs want to minimize the price of purchasing an offset credit, and sellers want to minimize the cost of producing them (King and Kuch, 2003).

MAC curves have been used in different sectors to identify cost-efficient means to meet with emission reduction targets (Kesicki, 2011). For instance, MAC curves have been used to analyze air pollutant reduction (Rentz et al., 1994), waste reduction (Beaumont and Tinch, 2004), water consumption reduction (Addams et al., 2009), and mitigation potential of technical practices in the agriculture sector (Bockel et al., 2012) to prioritize investment opportunities and shape policy discussions.

\subsubsection{Phosphorus trading analysis}

Step 1: Cap and allocations

In the present study, the cap was defined as the TP loading feasibly achieved at the zone level by implementing the three available types of BMPs per land use (owner, typical, and alternative) within the study area (Table 3-S1). This means that the sum of the TP loads attenuated to the nearby stream from all land uses should be equal or less than the cap. A proportionality factor, based on the zone attenuation factor obtained for the entire S-191 sub-basin, was then applied to translate the cap set at the land users' zone location to the S-191 sub-basin outlet. This was done to account for the fact that the TP loads discharged at the nearby stream will be attenuated before reaching the basin 
outlet. The resulting area normalized allocation load $\left(\mathrm{kg} \mathrm{P} \mathrm{ha}^{-1} \mathrm{yr}^{-1}\right)$ was then set for every TP loading source in the sub-basin.

\section{Step 2: Cost under a Command-and-Control approach}

Under this approach, the cost was calculated based on the BMPs available that can be implemented to meet TP loading individual allocations (Table 3-S2). The corresponding TP removal efficiencies for each land use per BMP type are presented in Table 3-S3. The TP load $\left(L^{\prime}{ }_{i, j}\right.$ in mtons $\left.\mathrm{P} \mathrm{yr}^{-1}\right)$, if BMPs were implemented, was calculated for each land use and zone following Equation (3-S1).

$$
L_{i, j}^{\prime}=\left(1-r_{k, j}\right) \times L_{i, j}
$$

where $r_{k, j}$ is the TP load reduction percentage obtained at the land use $j$ due to the

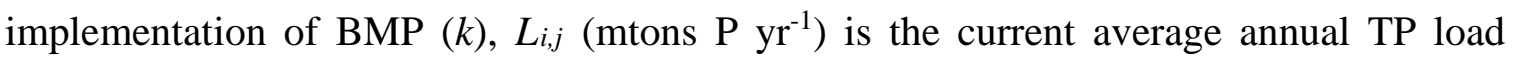
discharged from land use $(j)$ located in zone $(i)$ obtained from the output of the WAM model for the simulation period of $2002-2009$.

The TP load $\left(L^{\prime}, i, j\right)$ after BMP implementation under a Command-and-Control approach represents the baseline load. The difference between this baseline TP load and the TP load obtained under a trading program determined the number of credits to purchase or to sell in a market program (Corrales et al., 2013). The total sub-basin load reduction target at the zone level (Target_Pred) for the S-191 sub-basin was calculated by adding the TP load reductions across all TP sources within the area. The cost of BMP implementation was also estimated for each zone and land use combination $(i, j)$ using Equation (3-S2).

$$
C_{i, j}^{\prime}=c_{k, j} \times a_{i, j}
$$


where $c k, j\left(\$ \mathrm{ha}^{-1} \mathrm{yr}^{-1}\right)$ is the annual cost per area and per implemented BMP (Table 3-S2) and $a_{i, j}$ (ha) is the area of each land use per zone (Table 3-S4). The annual costs included the amortized capital cost at $10 \%$ interest over a twenty-year life span and the annual operation and maintenance (O\&M) costs represented $20 \%$ per year of the capital cost (SWET, 2006). The total cost of the Command-and-Control approach (tot_c') was estimated by adding the individual costs.

Step 3: Cost under the Least-Cost Abatement approach

The mathematical optimization model described in Equations (3-2) - (3-4) developed in the paper, was solved to determine the optimal combination of BMPs to achieve the TP load reduction target (Target_Pred) at the lowest cost. TP loads per land use and zone $\left(L{ }^{\prime}{ }_{i, j}\right)$ and individual $\left(c{ }^{\prime}{ }_{i, j}\right)$ and total costs (tot_c' $)$ after optimal-BMPs have been selected, were also calculated. The difference in total costs (tot_c' - tot_c') between Command-and-Control and Least-Cost Abatement approaches, identifies the maximum potential cost savings of the TP credit trading program.

Step 4: Credit price and identification of sellers and buyers

Total Abatement Cost (TAC) curve was derived for the S-191 sub-basin by running the optimization model and recording the cost of achieving different TP load targets. The slope of the cost versus TP load curve reflected the credit price or the maximum price that pollution sources are willing to pay for removing an additional unit of pollutant (Field and Field, 2006). Theoretically, this slope also represents the equimarginal abatement costs across all the sources at the respective loading target. Land users discharging above their baseline, obtained under the Command-and-Control approach 
$\left(L^{\prime}{ }_{i, j}\right)$, were identified as buyers of credits. On the other hand, land users discharging below their baseline were identified as credit sellers.

Step 5: Credits traded and cost

The amount of credits needed (Creditsneeded) for buyers to offset the difference in TP load between the Command-and-Control and Least-Cost Abatement approaches was subject to a trading ratio (TR) to account for differences in load attenuation from each discharger relative to the basin outlet (Kardos and Obropta, 2011; Lal et al., 2009; Ribaudo and Gottlieb, 2011). Attenuation factors, previously determined for different zones, were used to calculate the buyer-to-seller TR following Equation (3-S3). Therefore, the number of credits a buyer will purchase depended on the buyer and seller's zone location and were calculated following Equation (3-S4).

$T R=\frac{(1-\text { Buyer's attenuation factor })}{(1-\text { Seller's attenuation factor })}$

Number of Credits $_{\text {bought }}=T R \times$ Number of Credits $_{\text {needed }}$

The cost of the credits $\left(c^{\left.\prime,{ }_{i, j}\right)}\right.$ was based on the number of credits bought and the credit price plus a transaction fee of $10 \%$ of the credit price (Stavins, 2003). It is worth noticing that the transaction fee was only added to the costs when purchasing credits.

Step 6: Cost savings and a trading scenario

The net cost savings for each source trading credits was calculated following Equations (3-S5) and (3-S6). The cost savings for a seller was calculated by subtracting the additional cost incurred under the Least-Cost Abatement approach from the market value of credits sold as shown in Equation (3-S5). The additional cost, represented by the expression within the parenthesis, is resulting from the implementation of more capital- 
intensive BMPs through the Least-Cost Abatement approach, i.e., the incremental costs of shifting from a command and control scenario to a Least-Cost Abatement scenario. In contrast, the cost savings for a buyer was calculated by subtracting the cost of buying (including the cost obtained after optimization, cost of purchasing credits and transaction costs) from the cost incurred under the Command-and-Control approach as expressed in Equation (3-S6).

$$
\begin{aligned}
& \text { Savings }_{\text {sellers }}=c^{\prime \prime \prime}{ }_{i, j}-\left(c^{\prime \prime}{ }_{i, j}-c_{i, j}^{\prime}\right) \\
& \text { Savings }_{\text {buyers }}=c^{\prime}{ }_{i, j}-\left(c^{\prime \prime}{ }_{i, j}+c^{\prime \prime \prime}{ }_{i, j}+\text { trans.fee }\right)
\end{aligned}
$$

Considering that a buyer cost savings will be maximized if credits were bought from a source downstream of its own location, buyers with less cost savings were first allowed to purchase credits from sellers located in the closest zones to the basin outlet. The grand total cost savings from a trading program relative to a Command-and-Control approach adopted within the S-191 sub-basin was estimated by combining the individual cost savings from all buyers and sellers sources.

\subsubsection{References}

Addams, L., Boccaletti, G., Kerlin, M., Stuchtey, M., 2009. Charting our water future Economic frameworks to inform decision-making. McKinsey \& Company, New York, NY.

Beaumont, N.J., Tinch, R., 2004. Abatement cost curves: a viable management tool for enabling the achievement of win-win waste reduction strategies? J. Environ. Manage. 71, 207-215.

Bockel, L., Sutter, P., Touchemoulin, O., Jönsson, M., 2012. Using marginal abatement cost curves to realize the economic appraisal of climate smart agriculture policy options. Food and Agriculture Organization of the United Nations (FAO), Viale delle Terme di Caracalla, 00153 Rome, Italy. 
Corrales, J., Naja, G.M., Miralles-Wilhelm, F., Bhat, M.G., 2013. Water quality trading programs towards solving environmental pollution problems. Irrig. and Drain. 62 (Suppl. 2), 72-92.

Field, B.C., Field, M.K., 2006. Environmental economics: An introduction, fourth ed. McGraw Hill-Irwin, New York, NY.

Kardos, J.S., Obropta, C.C., 2011. Water quality model uncertainty analysis of a pointpoint source phosphorus trading program. J. Am. Water Resour. As. 47, 1317-1337.

Kesicki, F., 2011. Marginal abatement cost curves for policy making - expert-based vs. model-derived curves. UCL Energy Institute, University College London, London, United Kingdom.

King, D., Kuch, P., 2003. Will nutrient credit trading ever work? An assessment of supply and demand problems and institutional obstacles. Environmental Law Reporter 33, 10352-10368.

Knisel, W.G., 1993. GLEAMS groundwater loading effects of agricultural management systems. version 2.10. Dept. Publication No.5, Biological \& Agricultural Engineering Department. University of Georgia-Coastal Plain Experiment Station, Tifton.

Lal, H., Delgado, J.A., Gross, C.M., Hesketh, E., McKinney, S.P., Cover, H., Shaffer, M., 2009. Market-based approaches and tools for improving water and air quality. Environ. Sci. Policy 12, 1028-1039.

Rentz, O., Haasis, H.D., Jattke, A., Ru, P., Wietschel, M., Amann, M., 1994. Influence of energy-supply structure on emission-reduction costs. Energy 19, 641-651.

Ribaudo, M.O., Gottlieb, J., 2011. Point-nonpoint trading- Can it work? J. Am. Water Resour. As. 47, 5-14.

Stavins, R., 2003. Market-based environmental policies: What can we learn from U.S. experience (and related research)? Resources for the Future, Washington, D.C., p. 28.

SWET, 2006. Letter Report Entitled: Phosphorus Reduction Performance and Implementation Costs under BMPs and Technologies in the Lake Okeechobee Protection Plan Area. Soil and Water Engineering \& Technology Inc., Gainesville, FL.

SWET, 2008. EAAMOD technical and user manuals. Final reports to the Everglades Research and Education Center, University of Florida. Soil and Water Engineering \& Technology, Inc., Belle Glade, FL. 
SWET, 2011. Watershed Assessment Model documentation. Soil and Water Engineering \& Technology, Inc., Gainesville, FL. 


\subsubsection{Tables}

Table 3-S1. Best Management Practices (BMPs) description.

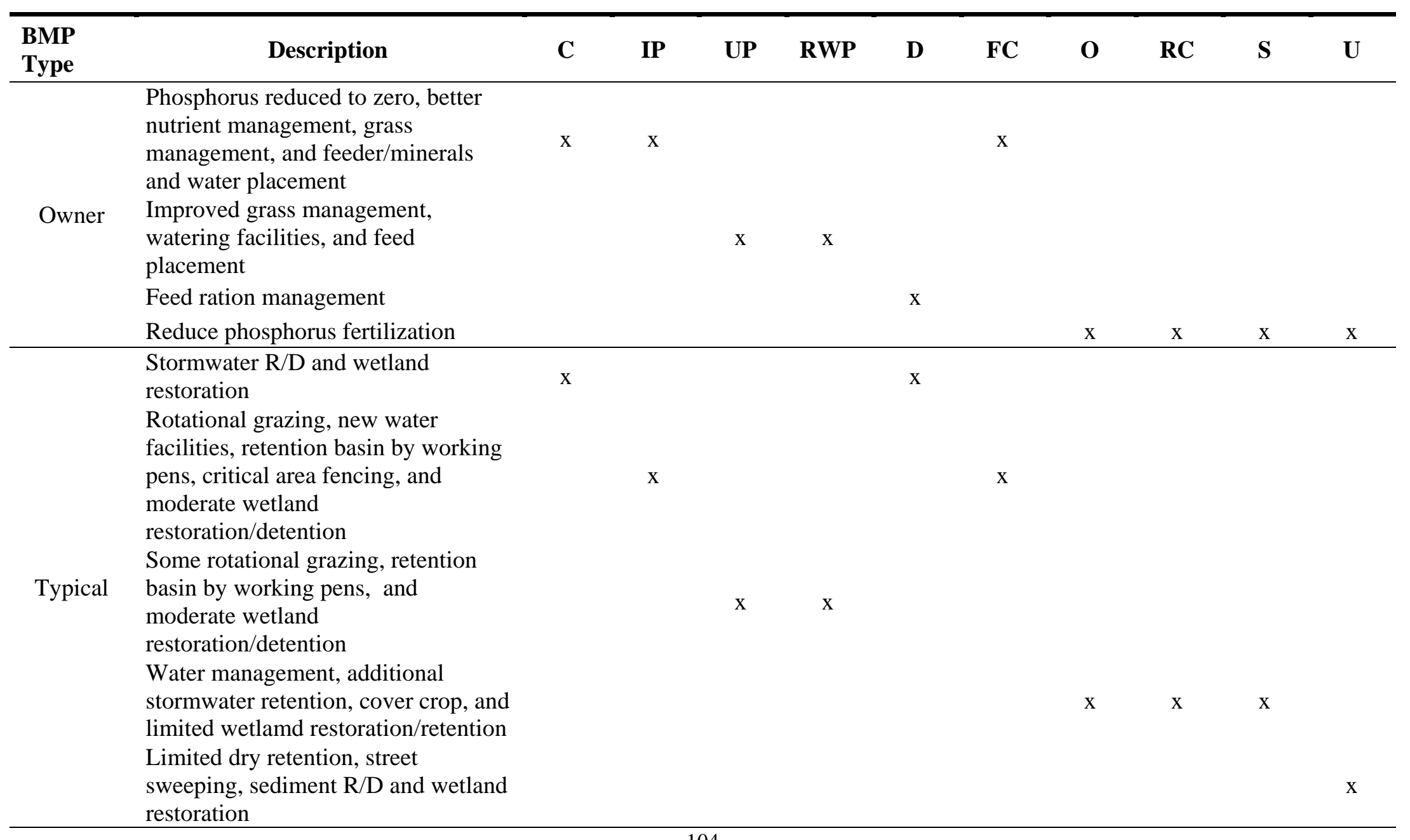


Table 3-S1. Continued.

\begin{tabular}{|c|c|c|c|c|c|c|c|c|c|c|c|}
\hline ВМР Туре & Description & C & IP & UP & RWP & D & FC & $\mathbf{O}$ & $\mathbf{R C}$ & $\mathbf{S}$ & $\mathbf{U}$ \\
\hline Alternative & $\begin{array}{l}\text { Fertigation, grassed waterways, and } \\
\text { edge-of-farm stormwater R/D with } \\
\text { chemical treatment } \\
\text { Provide alternative shade to move } \\
\text { cattle from streams, and edge-of- } \\
\text { farm Stormwater R/D and chemical } \\
\text { treatment } \\
\text { Critical area fencing, and edge-of- } \\
\text { farm stormwater R/D and chemical } \\
\text { treatment } \\
\text { Solids separation for off site } \\
\text { disposal, add housing to move } \\
\text { animals off field, stormwater } \\
\text { retention/expanded sprayfields, edge- } \\
\text { of-field chemical treatment, buffer } \\
\text { strips, edge-of-farm stormwater R/D } \\
\text { and chemical treatment, water reuse } \\
\text { from R/D ponds, erosion control, and } \\
\text { edge-of-farm stormwater R/D and } \\
\text { chemical treatment } \\
\text { Edge-of-farm stormwater R/D and } \\
\text { chemical treatment } \\
\text { Water reuse from R/D ponds, erosion } \\
\text { control, and edge-of-farm } \\
\text { stormwater R/D and chemical } \\
\text { treatment }\end{array}$ & $\mathrm{x}$ & $\mathrm{x}$ & $\mathrm{x}$ & $\mathrm{x}$ & $\mathrm{X}$ & $\mathrm{X}$ & $\mathrm{x}$ & $\mathrm{x}$ & $\mathrm{x}$ & $\mathrm{x}$ \\
\hline
\end{tabular}

R/D: Retention and detention; C: Citrus; IP: Improved pastures; UP: Unimproved pastures; RWP: Rangeland and wooded pastures; D: Dairies; FC: Field crops; O: Ornamentals; RC: Row crops; S: Sod; U: Urban. 
Table 3-S2. Annual cost of implementing the three BMP types per land use and per area $\left(\$ \mathrm{ha}^{-1} \mathrm{yr}^{-1}\right)$ (from SWET, 2006).

\begin{tabular}{crrrrrrrrrr}
\hline $\begin{array}{c}\text { BMP } \\
\text { Type }\end{array}$ & Citrus & $\begin{array}{c}\text { Improved } \\
\text { Pastures }\end{array}$ & $\begin{array}{c}\text { Unimproved } \\
\text { Pastures }\end{array}$ & $\begin{array}{c}\text { Rangeland } \\
\text { and } \\
\text { Wooded } \\
\text { Pasture }\end{array}$ & Dairies & $\begin{array}{c}\text { Field } \\
\text { Crop }\end{array}$ & Ornamentals & $\begin{array}{c}\text { Row } \\
\text { Crop }\end{array}$ & Sod & Urban \\
\hline I & - & 11.6 & 2.9 & 2.9 & 5.8 & 11.6 & 11.6 & 10.2 & 6.4 \\
II & 71.4 & 46.4 & 14.5 & 14.5 & 973.0 & 46.4 & 205.8 & 204.0 & 104.9 & 463.8 \\
III & 294.6 & 147.8 & 66.7 & 66.7 & $1,483.1$ & 147.8 & 614.5 & 612.2 & 411.0 & $3,431.8$ \\
\hline
\end{tabular}

Table 3-S3. Best Management Practices (BMPs) efficiency - TP load reduction in percentage (\%) (from SWET, 2006).

\begin{tabular}{|c|c|c|c|c|c|c|c|c|c|c|}
\hline $\begin{array}{c}\text { ВMP } \\
\text { Type }^{\mathrm{a}}\end{array}$ & Citrus & $\begin{array}{l}\text { Improved } \\
\text { Pastures }\end{array}$ & $\begin{array}{l}\text { Unimproved } \\
\text { Pastures }\end{array}$ & $\begin{array}{c}\text { Rangeland } \\
\text { and } \\
\text { Wooded } \\
\text { Pasture }\end{array}$ & Dairies & $\begin{array}{l}\text { Field } \\
\text { Crop }\end{array}$ & Ornamentals & $\begin{array}{l}\text { Row } \\
\text { Crop }\end{array}$ & Sod & Urban \\
\hline $\mathrm{I}$ & $12 \%$ & $11 \%$ & $7 \%$ & $4 \%$ & $9 \%$ & $15 \%$ & $32 \%$ & $30 \%$ & $20 \%$ & $5 \%$ \\
\hline II & $32 \%$ & $30 \%$ & $20 \%$ & $10 \%$ & $37 \%$ & $40 \%$ & $67 \%$ & $60 \%$ & $47 \%$ & $10 \%$ \\
\hline III & $61 \%$ & $64 \%$ & $55 \%$ & $42 \%$ & $67 \%$ & $62 \%$ & $84 \%$ & $80 \%$ & $74 \%$ & $73 \%$ \\
\hline
\end{tabular}

aType I: Owner type BMPs; Type II: Owner and typical BMPs; Type III: Owner, typical, and alternative BMPs. 
Table 3-S4. Land use distribution per zone in the S-191 sub-basin (ha).

\begin{tabular}{|c|c|c|c|c|c|c|}
\hline & Zone 1 & Zone 2 & Zone 3 & Zone 4 & Zone 5 & Zone 6 \\
\hline Citrus & - & 49 & 45 & 474 & 414 & 433 \\
\hline Improved Pastures & 669 & 4,529 & 5,087 & 5,545 & 4,398 & 7,144 \\
\hline Unimproved Pastures & 3 & 113 & 740 & 487 & 142 & 86 \\
\hline $\begin{array}{l}\text { Rangeland and Wooded } \\
\text { Pastures }\end{array}$ & - & 66 & 60 & 34 & 41 & - \\
\hline Dairies & 517 & 741 & 217 & 162 & 336 & 237 \\
\hline Field Crop & - & 575 & 162 & 514 & 231 & 263 \\
\hline Ornamentals & 21 & 20 & 96 & 76 & 9 & - \\
\hline Row Crop & - & 6 & 10 & 61 & 32 & 105 \\
\hline Sod & - & 286 & - & - & 81 & 6 \\
\hline Urban & 138 & 768 & 990 & 376 & 35 & 116 \\
\hline
\end{tabular}

Table 3-S5. Delivery trading ratios.

\begin{tabular}{ccccccc}
\hline \multirow{2}{*}{$\begin{array}{c}\text { Buyer's } \\
\text { location }\end{array}$} & Zone 1 & Zone 2 & Zone 3 & Zone 4 & Zone 5 & Zone 6 \\
\hline Zone 1 & 1.00 & 1.02 & 1.04 & 1.06 & 1.09 & 1.14 \\
Zone 2 & 0.98 & 1.00 & 1.02 & 1.04 & 1.07 & 1.11 \\
Zone 3 & 0.96 & 0.98 & 1.00 & 1.02 & 1.04 & 1.09 \\
Zone 4 & 0.94 & 0.96 & 0.98 & 1.00 & 1.02 & 1.07 \\
Zone 5 & 0.92 & 0.94 & 0.96 & 0.98 & 1.00 & 1.05 \\
Zone 6 & 0.88 & 0.90 & 0.92 & 0.94 & 0.96 & 1.00 \\
\hline
\end{tabular}

Table 3-S6. Total phosphorus load attenuated to the nearby stream per land use and per zone in the S-191 sub-basin $\left(\mathrm{kg} \mathrm{ha}^{-1} \mathrm{yr}^{-1}\right)$.

\begin{tabular}{lrrrrrr}
\hline Land Use & Zone 1 & Zone 2 & Zone 3 & Zone 4 & Zone 5 & Zone 6 \\
\hline Citrus & - & 1.1 & 0.8 & 0.8 & 0.8 & 0.9 \\
Improved Pastures & 1.5 & 2.5 & 1.6 & 2.0 & 1.8 & 1.7 \\
Unimproved Pastures & 0.8 & 0.7 & 0.6 & 0.8 & 0.5 & 0.5 \\
Rangeland and Wooded & - & 1.0 & 0.6 & 0.6 & 0.6 & - \\
Pasture & - & & & & \\
Dairies & 8.9 & 8.2 & 10.9 & 13.4 & 11.1 & 6.7 \\
Field Crop & - & 5.4 & 4.5 & 4.9 & 4.8 & 3.7 \\
Ornamentals & 11.3 & 9.4 & 5.0 & 9.4 & 9.6 & - \\
Row Crop & - & 2.5 & 2.5 & 2.3 & 2.0 & 2.1 \\
Sod & - & 5.2 & - & - & 6.0 & 3.1 \\
Urban & 0.9 & 0.5 & 0.5 & 0.2 & 0.5 & 0.4 \\
\hline
\end{tabular}


Table 3-S7. Total phosphorus load attenuated to the nearby stream per land use after Best Management Practice (BMP) implementation under a Command-and-Control approach and a Least-Cost Abatement scenario.

\begin{tabular}{lrrr}
\hline Land Use & $\begin{array}{c}\text { TP load under } \\
\text { Command-and- } \\
\text { Control } \\
\mathbf{( k g ~ y r}^{-1} \mathbf{)}\end{array}$ & $\begin{array}{c}\text { TP load under } \\
\text { Least-Cost } \\
\text { Abatement } \\
\mathbf{( k g ~ y r}^{-\mathbf{1}} \mathbf{)}\end{array}$ & $\begin{array}{c}\text { Potential } \\
\text { buyer or } \\
\text { seller }\end{array}$ \\
\hline Citrus & 1,197 & 1,054 & Seller \\
Improved Pastures & 37,565 & 25,934 & Seller \\
Unimproved Pastures & 1,040 & 1,040 & - \\
Rangeland and Wooded Pastures & 148 & 148 & - \\
Dairies & 6,780 & 17,780 & Buyer \\
Field Crop & 3,223 & 3,223 & - \\
Ornamentals & 273 & 592 & Buyer \\
Row Crop & 311 & 396 & Buyer \\
Sod & 522 & 940 & Buyer \\
Urban & 1,136 & 1,079 & Seller \\
\hline & $\mathbf{5 2 , 1 9 6}$ & $\mathbf{5 2 , 1 8 8}$ & \\
\hline
\end{tabular}

Note: Total Phosphorus loads were expressed in kilograms (kg) to identify the buyer and seller sources and the respective number of credits to be purchased or available to sell. 


\subsubsection{Figures}

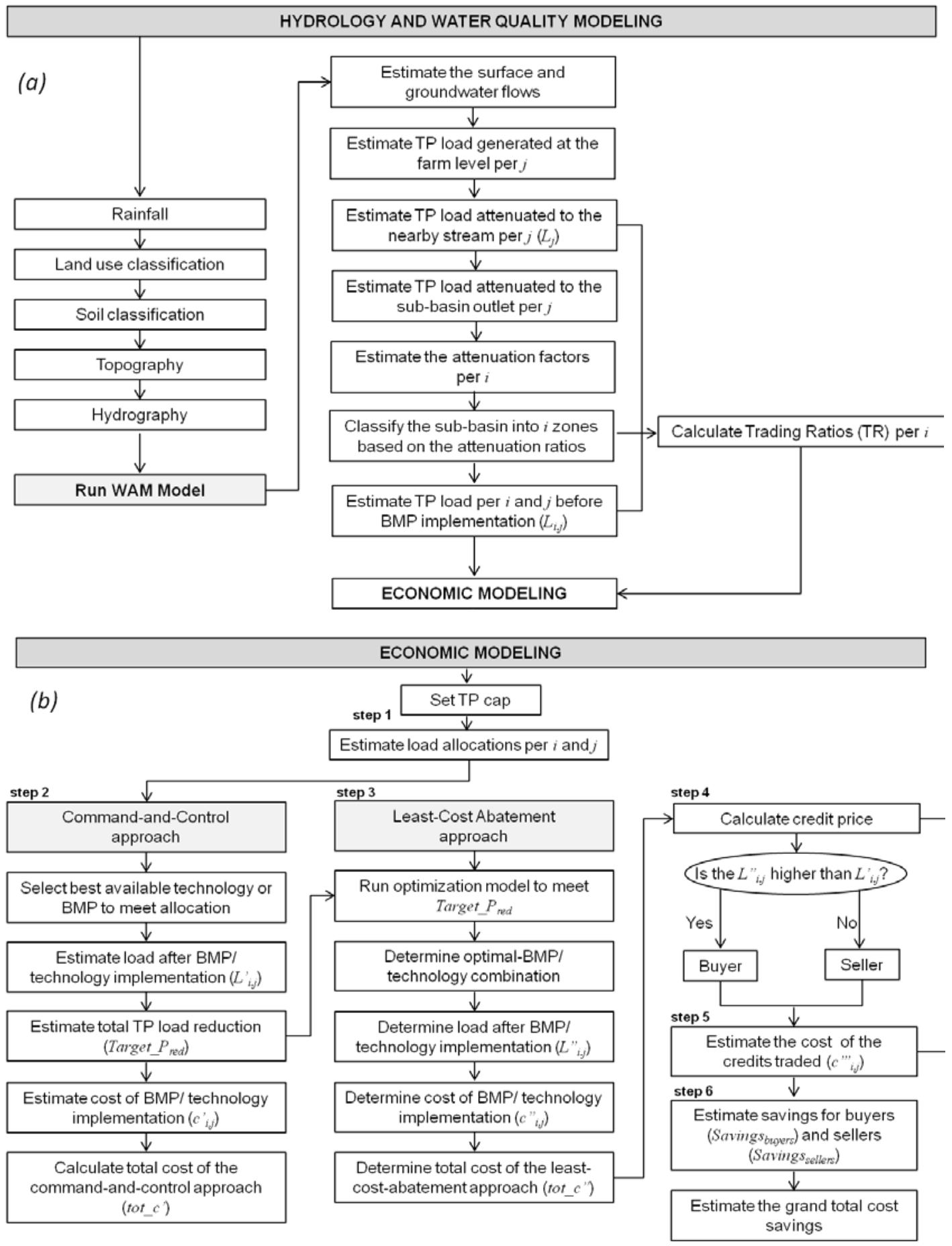

Figure 3-S1. Diagram illustrating the methodology followed to: (a) estimate the total phosphorus (TP) loadings before implementation of Best Management Practices (BMPs) at each zone $i$ and land use $j$ as well as the trading ratios (TR) at each zone $i$, and (b) assess the trading program cost savings. 
(a)

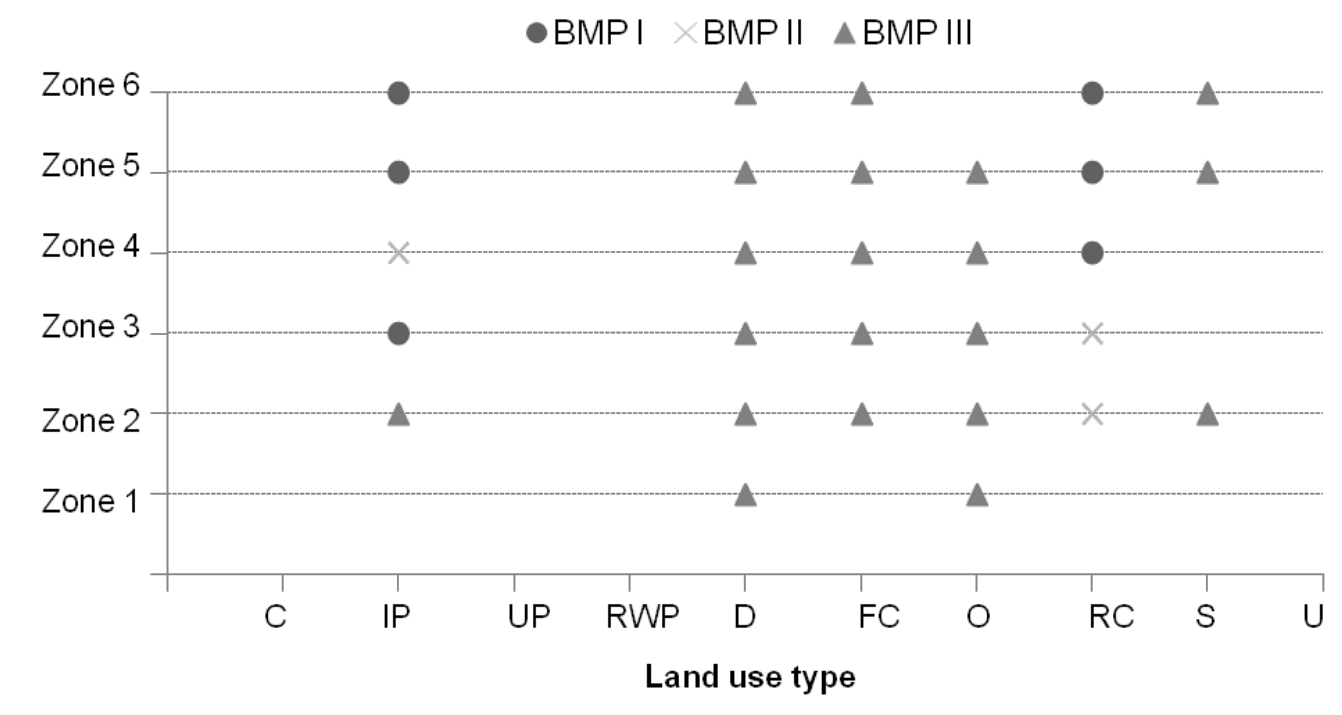

(b)

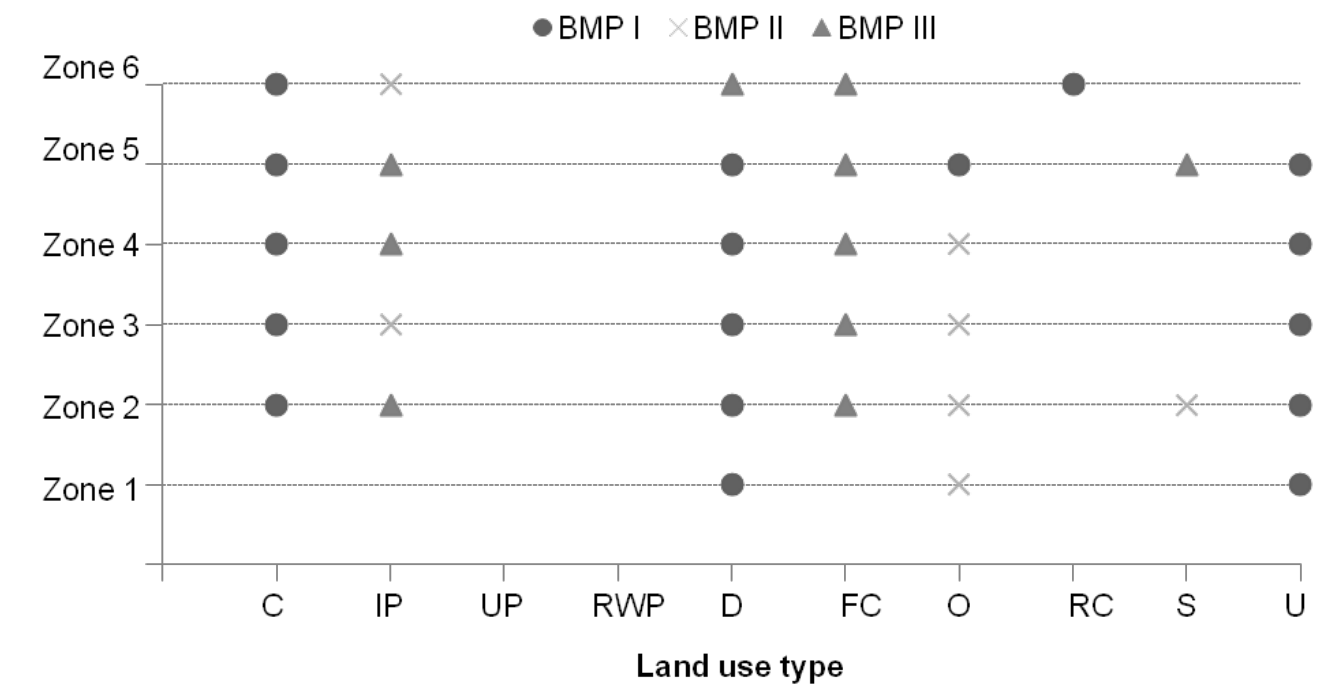

Figure 3-S2. (a) Best Management Practices (BMP) selected under a Command-andControl approach and (b) under a Least-Cost Abatement scenario. C stands for citrus, IP for improved pastures, UP for unimproved pastures, RWP for rangeland and wooded pastures, D for dairies, FC for field crops, O for ornamentals, RC for row crops, S for sod, and $\mathrm{U}$ for urban 


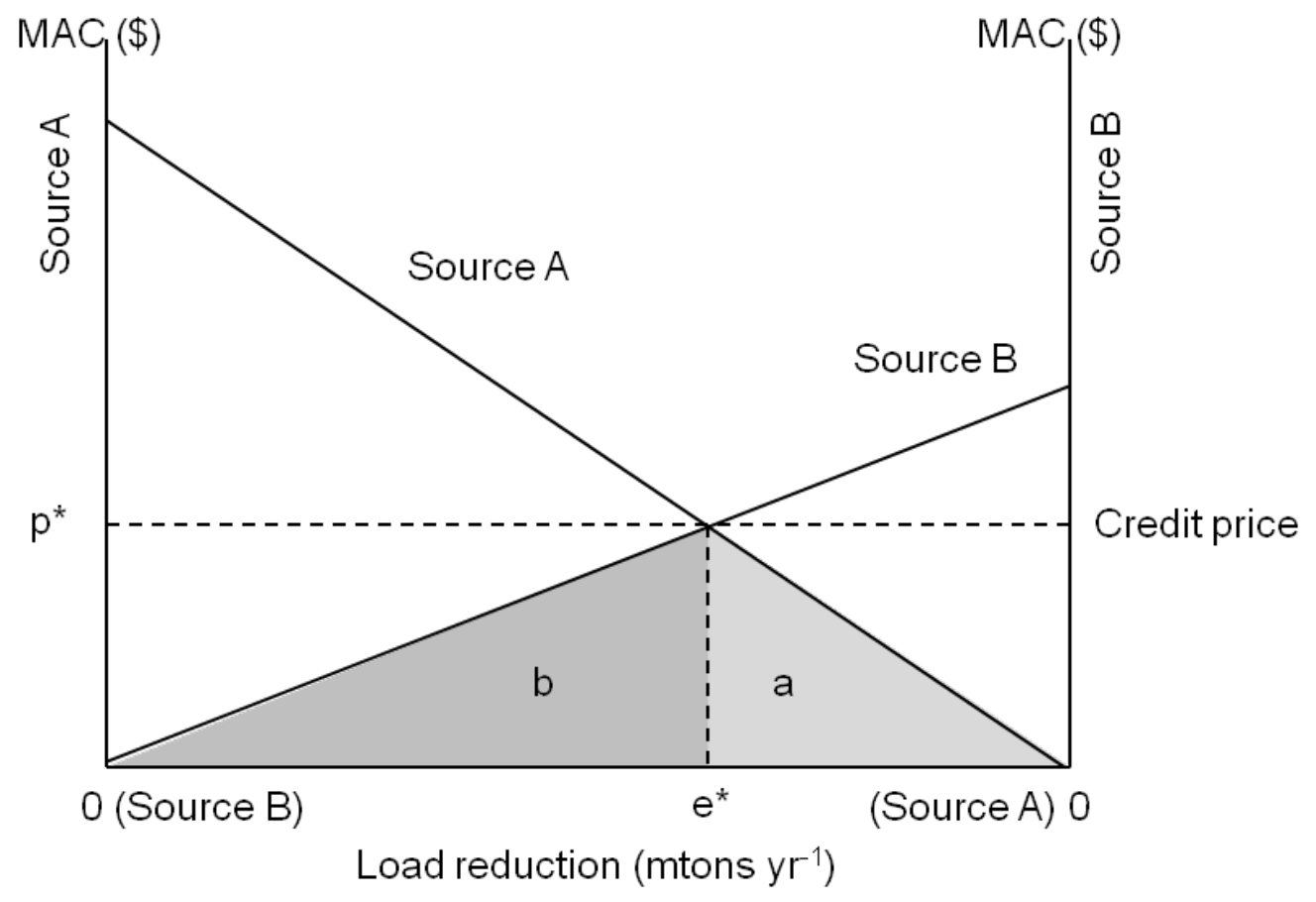

Figure 3-S3. Credit price identification from the Marginal Abatement Cost (MAC) curves. 


\section{CHAPTER 4}

\section{WATER QUALITY TRADING OPPORTUNITIES IN TWO SUB-WATERSHEDS \\ IN THE NORTHERN LAKE OKEECHOBEE WATERSHED}

\subsection{Introduction}

Affecting both freshwater and coastal ecosystems, nutrient eutrophication is a subtle yet rapidly growing environmental problem of international significance. Phosphorus plays a critical role in the impairment of fresh waterbodies. Addressing the high levels of phosphorus reaching the ecosystems is a challenging task, which integrates a multifaceted program with the participation of agencies, academic institutions, the private sector, and other stakeholders. Phosphorus source control efforts, currently implemented to reduce phosphorus in the runoff from watersheds, have not yet yielded the desired improvements in water quality (Jarvie et al., 2013), particularly in complex and large watersheds, such as the Lake Okeechobee watershed (LOW) in Florida, USA (Figure 4-1). Anthropogenic factors, and hydrologic and land use modifications in the LOW have led to water quality impairment of Lake Okeechobee (LO) (FDEP, 2014). The water quality impairment has been mainly linked to excessive phosphorus loadings, originating from diverse sources, including agriculture and livestock, municipal and industrial discharges, and urban stormwater runoff (FDEP, 2001). Anthropogenic additions of phosphorus altered many aspects of the structure and function of LO's ecosystem (Havens and Gawlik, 2005). In order to prevent further degradation of the lake and protect its designated uses (e.g., drinking, fishing, recreation, irrigation, etc.), the Florida Department of Environmental Protection (FDEP) adopted a Total Maximum Daily Load (TMDL), establishing an 
annual target load for total phosphorus (TP) of 140 metric tons (mtons) to be discharged into LO from all sources in the watershed and from atmospheric deposition (Zhao et al., 2012). The TMDL is intended to be achieved in a multi-phased approach by the implementation of a series of projects and programs delineated in the LO Basin Management Action Plan (BMAP). The first phase of this BMAP includes projects that

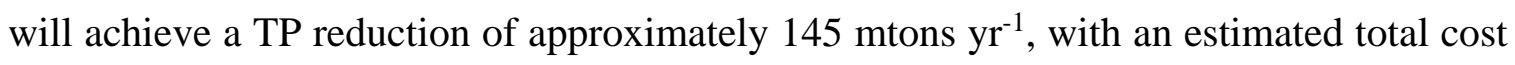
of more than \$ 937.7 million (FDEP, 2014). Additional projects and resources would be needed to achieve the TMDL and to further improve the water quality of the lake. Consequently, it is imperative to establish economic incentive policies to address the phosphorus problem in the lake and its watershed in a cost-effective way.

The theoretical promise of market-based systems to assist in meeting water quality standards at an overall lower cost than conventional regulatory approaches and the encouragement from the U.S. Environmental Protection Agency (USEPA), has led to significant attention to water quality trading as a policy alternative to support TMDL implementation (Horan and Shortle, 2011). In general, water quality trading programs utilize a market-based approach that allows sources to comply with their regulatory obligations by using reductions achieved by other sources. These additional reductions generally translate into credits with a monetary value that may be sold to sources with high marginal abatement costs within the watershed (Field and Field, 2006). Advantages of market-based approaches include the involvement of non-regulated nonpoint sources to address watershed water quality impairment problems (Shortle and Horan, 2006). In addition, these incentive-based alternatives offer flexibility to pollution sources to find cost-effective means of meeting individual loading limits (Collentine, 2006). 
The current study builds on a previous investigation conducted by Corrales et al. (2014), which designed a modeling framework to quantify TP loadings from nonpoint sources and evaluate the cost savings that could potentially result from implementing a WQTP, in comparison to a conventional regulatory or command-and-control (CAC) approach. Several novel aspects were examined in the present study. First and foremost, the phosphorus sources allowed to participate in the trading program were extended to both nonpoint and point sources. Indeed, a more diverse pool of trading sources could increase the potential financial attractiveness of the program by creating differences in the control costs faced by individual sources (Newell and Stavins, 2003). Second, the geographic boundaries of the study areas were expanded to two larger and more hydrological complex sub-watersheds than the region examined in Corrales et al. (2014). Third, recognizing that the potential economic gains associated with trading are influenced by diverse factors specific to the trading area (USEPA, 2003c), this paper assessed the potential cost savings of a trading program in two sub-watersheds with a direct or an indirect discharge location relative to $\mathrm{LO}$ and with distinct land use characteristics. Fourth, the optimal cap per study area was selected through an optimization process considering several factors impacting the market potential, namely the least-cost solutions, credit prices, potential cost savings, and credit supply and demand. Hypothetical trading scenarios were also developed, using the optimal caps selected for the two sub-watersheds, to highlight the economic advantages of a WQTP over a CAC approach in order to improve LO's water quality.

Furthermore, the present study is intended to provide the public and private sectors with critical information to assess the environmental and economic potential of WQTPs 
to reduce TP loadings into LO and to determine whether WQTPs are worth further exploration and development. Although the potential of a WQTP is illustrated here through case studies, the same analysis could be applied in other watersheds to explore the feasibility of a trading program in order to achieve water quality goals in a costeffective way.

\subsection{Materials and Methods}

\subsubsection{Study areas description}

The Lake Okeechobee watershed (LOW), divided in nine sub-watersheds on the basis of hydrology and geography, drains into Lake Okeechobee (LO) (Figure 4-1). Two subwatersheds, Upper Kissimmee (UK) and Taylor Creek/Nubbin Slough (TCNS), were used as study areas to evaluate and compare the cost effectiveness of implementing a water quality trading program (WQTP) to reduce the phosphorus emissions reaching LO. The two sub-watersheds have different land use and hydrologic characteristics and have been identified as major sources of total phosphorus (TP) loadings to the lake. In the case of the UK sub-watershed, TP loads are mainly the result of high surface water flows (Sharfstein et al., 2015). In the case of the TCNS sub-watershed, TP loads are associated to high TP loads per unit area originating from dairy farms and beef cattle ranches (Hiscock et al., 2003; Zhao et al., 2012). Therefore, water quality improvements in these areas could significantly contribute to reducing TP loadings to LO.

Upper Kissimmee sub-watershed

The UK sub-watershed, located north of LO, covers approximately 4,150 $\mathrm{km}^{2}$ (414,994 ha), representing 35\% of the total drainage area of the lake. Lake Kissimmee 
and the Chain of Lakes in Orange and Osceola counties (SFWMD et al., 2011) are located in the UK sub-watershed and represent the major hydrologic components of the area (Figure 4-2a). The land use in the UK sub-watershed is mainly composed of natural areas (56\%), such as wetlands, forest, and water bodies; followed by agricultural areas (24\%), including citrus groves, improved pastures, and sod farms, and by urban areas (21\%), such as residential, commercial, industrial, and institutional areas (Table 4-1). In addition, the largest wastewater facilities within the LOW are located in this subwatershed. With a historical average annual rainfall of 1,272 $\mathrm{mm}$ (Abtew and Ciuca, 2015), runoff from the UK sub-watershed is directly reaching the Kissimmee River (C-38 canal) through the S-65 spillway and passes through several downstream basins before reaching LO. As a result of the large surface flows, this sub-watershed contributes significant TP loads into the lake. According to the data from the South Florida Water Management District (SFWMD) DBHYDRO database, the UK sub-watershed accounted for approximately 39\% (750,170 acre-feet) of the total inflow and 18\% (77.3 mtons) of TP loads to LO for the period from 2000 - 2013.

\section{Taylor Creek/Nubbin Slough sub-watershed}

The TCNS sub-watershed covers $7 \%\left(785 \mathrm{~km}^{2}\right)$ of the LOW and drains into LO from the northeast through the S-191 flow control structure (Figure 4-2b). The hydrology is dominated by creeks, sloughs, and canals. The historical average annual rainfall is 1,168 mm (Abtew and Ciuca, 2015), and the land use of this sub-watershed is mainly constituted of agricultural lands (67\%), such as improved pastures, dairy farms, and sugarcane, natural areas (20\%), as well as urban areas (13\%) (Table 4-1). Because of the large TP loads generated from this sub-watershed, it has been listed as a priority area for 
the implementation of several TP source control programs. According to the data from DBHYDRO, the TCNS sub-watershed accounted for approximately 22\% (93.0 mtons) of the TP loads discharged to LO for the period from 2000 - 2013.

\subsubsection{Identification of sources of phosphorus and quantification of loadings}

\section{Point sources}

Point sources (PS) are pollution sources that have a confined and identifiable effluent location, such as wastewater treatment facilities (WWTFs) and concentrated animal feeding operations (CAFOs), where animals are maintained in confined situations. Any PS discharging to surface waters is subject to the Florida Department of Environmental Protection's (FDEP) federally authorized National Pollutant Discharged Elimination System (NPDES) requirements. The UK sub-watershed has 115 domestic and industrial wastewater facilities with a total permitted flow capacity of 145 million gallons per day (MGD) (FDEP, 2015). The majority of these facilities use conventional secondary biological treatment processes typically designed to remove suspended solids and organic compounds and a lesser extent, to remove nutrients (nitrogen and phosphorus). In addition, these facilities sell their reclaimed water for reuse purposes to further reduce nutrient and other contaminant loads. Only two facilities are equipped with Advanced Wastewater Treatment (AWT) systems specifically designed to remove nutrients. In the TCNS sub-watershed, there are 26 domestic and industrial facilities, nine of which are concentrated cow/calf feeding operations (CAFOs), and only one facility with implemented AWT technology have a design flow capacity greater than 1 MGD. Given that WWTFs are increasingly being required to implement advanced treatment processes to reduce effluent concentrations to levels that regulators deem sufficiently protective of 
the environment, this study focused on facilities with a permitted flow capacity exceeding 1 MGD and that do not have AWT systems currently in place (TP concentration exceeding $0.1 \mathrm{mg} \mathrm{L}^{-1}$ ). Facilities with a permitted flow less than 1 MGD account only for $4 \%$ of the total combined flow in the two studied sub-watersheds (147.6 MGD) and therefore, are not expected to be significant phosphorus loading contributors. A TP concentration of $0.1 \mathrm{mg} \mathrm{L}^{-1}$ was used to select facilities with no AWT technologies (on the basis of performance data from 30 different facilities) (USEPA, 2008). According to the above selection criteria, Figure 4-3a shows the location of the PS selected for this study (i.e., 12 WWTFs with a combined permitted daily flow of 108 MGD), all located in the UK sub-watershed. The TP loads discharged at the end-of-pipe from these WWTFs was quantified using the TP effluent concentrations and on the average water flows from the monitoring reports obtained from the FDEP OCULUS database (FDEP, 2015). The time period used to calculate TP loads differed for each facility and was determined by available information of TP effluent concentrations.

It is worth mentioning that all the CAFOs were located in the TCNS sub-watershed (Figure 4-3b) and were also included in the analysis. The CAFO TP loadings were quantified using the same methodology used to determine the nonpoint sources' TP loadings.

Nonpoint sources

Nonpoint sources (NPS) are polluting sources discharging over relative large diffuse areas. Examples of NPS are runoffs originating from agricultural and urban areas. The location and type of NPS within the study areas were determined using the 2006 land use classification obtained from the SFWMD Geographical Information System (GIS) 
database (SFWMD, 2014). Figures 4-4a and 4-4b show the land use distribution for the UK and the TCNS sub-watersheds, respectively.

Given that NPS pollution discharges depend on several exogenous factors including land use, topography, vegetation, and sediment generation (Zhang et al., 2015), direct measurement of TP load discharges and removal efficiencies of different control practices is a challenging and often a very expensive task. Therefore, WQTPs rely on computer models and/or web-based platforms using site characteristics, such as rainfall, land use, and soil types to simulate the constituent loads generated at the source level. For instance, Zhang et al. (2015) used the Soil and Water Assessment Tool (SWAT) to simulate NPS contaminant loadings from agricultural zones for trading purposes in the Xiangxihe River watershed (China). Trading programs in the Kalamazoo River watershed (MI, USA) and the Chesapeake Bay watershed (USA) use the standardized nutrient loading estimation tool -NutrientNet-- to estimate loadings and potential reductions of different management strategies (Lal et al., 2009). In the present study, the Watershed Assessment Model (WAM) developed by Soil and Water Engineering Technology, Inc. was used as a TP load estimation tool at the source, stream, and subwatershed outfall levels. A detailed description of the model can be found in Corrales et al. (2014). The WAM model dynamically routes the flows and constituent loads to and through the stream network to the discharge location, allowing the quantification of the un-attenuated constituent loads (at the source level) and the attenuated loads (at the nearby stream system), after overland assimilation has been taken into account (SWET, 2011). The model has been extensively used in the LOW for a variety of projects (SWET, 2011) and it was recently applied by the FDEP for the LO Basin Management Action 
Plan (BMAP) development (FDEP, 2014). For the purpose of the present study, WAM was calibrated and validated for the UK sub-watershed and for three of the four basins of the TCNS sub-watershed (S-133, S-135, and S-154) (Figure 4-2b) for a simulation period from 2002 - 2009. Results of the calibration and validation analysis and goodness-of-fit (GOF) statistical measurements are reported in the Supplemental Information. The simulation period (2002 - 2009) was selected for the present study, because during this period minimal Best Management Practices (BMPs) were implemented in the two subwatersheds to reduce nutrient loadings from agricultural and urban areas (FDEP, 2014).

\subsubsection{Determination of attenuation rates and delivery trading ratios}

The TP loads from PS and NPS can be land and water assimilated through several physical-chemical-biological processes (Zhang et al., 2002). For TP loads generated from NPS, the overland attenuation was calculated using the WAM model as different attenuation rates were applied to nutrient loads depending on the type of landscape feature encountered en-route to a nearby reach (SWET, 2011). For TP loads generated from PS, an attenuation factor of $90 \%$ was used in order to estimate the TP loads attenuated to the nearby stream. The overland attenuation factor, taken from published data (Crites et al., 2000; Evanylo et al., 2010; USEPA, 2003b), reflects the attenuation of $\mathrm{TP}$ in reclaimed water discharged to a slow-rate public access reuse system, consisting of irrigation of residential lawns, golf courses, and landscape areas. In the present case, although the reclaimed water from PS was not directly discharged to a surface waterbody, it was assumed that the surface and groundwater catchment areas were similar in the subwatersheds. Therefore, the TP loads from PS were attributed to the WAM reach associated with the drainage area where the PS is located. 
The in-stream phosphorus attenuation was used to account for additional TP assimilation as different hydrologic conveyance features, such as slough, streams, and canals are encountered en-route to the sub-watershed outlet. A first order decay equation (Equation 4-1) was used to attenuate TP loads from the nearby stream to the subwatershed outlets. The main factors influencing the in-stream attenuation are the stream velocity and the rate of nutrient exchange between the water column and sediments (Corrales et al., 2014).

$C_{f}=C_{b}+\left(C_{o}-C_{b}\right) * e^{\left(-\frac{a}{v}\right)}$

where $C_{f}$ is the TP concentration at the outlet of the sub-watershed (mg L${ }^{-1}$ ), $C_{o}$ is the TP concentration at the outlet of each reach segment $\left(\mathrm{mg} \mathrm{L}^{-1}\right), C_{b}$ is the TP background concentration in the stream (mg L $\left.{ }^{-1}\right), v$ is the stream velocity $\left(\mathrm{m} \mathrm{s}^{-1}\right)$, and $a$ is the rate of load transfer $\left(\mathrm{m} \mathrm{s}^{-1}\right)$ referring to the rate at which TP is removed from the water column and retained in the stream sediments.

Values of $C_{b}$ and $a$ were calibrated for the UK sub-watershed and for the S-133, S135, and S-154 basins. Final values of $C_{b}$ and $a$ are reported in the Appendix for the two phosphorus forms: soluble (dissolved in the water) and non-soluble (attached to sediment particles).

Attenuation ratios were calculated using the difference in TP load attenuated to the sub-watershed outlet and the TP load attenuated to the nearby stream. Each subwatershed was then classified into zones defined by the attenuation ratio values, using the natural breaks (Jenks) classification method provided in ArcMap. The TP loads 
aggregated by zone represented the current average annual TP load per source considered in the analysis.

Attenuation rate values were used to estimate the delivery trading ratios (TRs) using Equation (4-2). The TRs were incorporated in the WQTP to provide equivalence between trading sources located at different distances relative to the impaired waterbody (Corrales et al., 2013; Feng et al., 2009). The TRs are an important feature of a WQTP, because they ensure that pollutant load reductions achieved at the seller's location would result in the same or better environmental improvement in the receiving waterbody than reductions attained at the buyer's location (USEPA, 2003c).

$T R=\frac{(1-\text { Buyer's attenuation factor })}{(1-\text { Seller's attenuation factor })}$

Once the TRs were assessed, the amount of credits needed from a potential buyer was adjusted using the buyer zone's TR to ensure that the proposed trade did not result in localized areas of high TP load or "hotspots".

\subsubsection{Phosphorus abatement approaches}

\section{Least-cost abatement approach}

In the present study, an extended version of the conceptual model developed in Corrales et al. (2014) was used to minimize the total costs of abating TP loads to achieve specific reduction TP targets. Similar models have been used in other studies to determine the least-cost load allocation to meet a given water quality goal (Van Houtven et al., 2012). The novel component of the present study is that the least-cost abatement (LCA) model was extended to include the participation of both PS and NPS to simulate a market-based WQTP. The allocation of a water quality goal for each sub-watershed was 
optimized among trading sources in such a way that sources with low marginal abatement costs would have higher TP reductions than sources with high marginal abatement costs, allowing reaching economic efficiency while achieving specific TP reduction targets. The LCA model approach, described in Equations (4-3) - (4-6), was solved using the General Algebraic Modeling System (GAMS) software. Table 4-2 provides the description and units of the variables used in the model.

Min $Z=\sum_{i} \sum_{k} \sum_{j} c_{i, k, j} \times X_{i, k, j}+\sum_{i} \sum_{m} \sum_{n} c_{i, m, n} \times Y_{i, m, n}$

Subject to:

$\sum_{i} \sum_{k} \sum_{j} L_{i, j} \times r_{k, j} \times X_{i, k, j}+\sum_{i} \sum_{m} \sum_{n} L_{i, n} \times r_{m, n} \times Y_{i, m, n} \geq$ Target__ $P_{\text {red }}$

$\sum_{k} X_{i, k, j} \leq 1 \quad \forall i, k, j$

$\sum_{m} Y_{i, m, n} \leq 1 \quad \forall i, m, n$

The objective function Min Z, represented in Equation (4-3), was set to minimize the cost of implementing 1) agricultural and urban BMPs for NPS and 2) AWT technologies for PS. The first constraint, presented in Equation (4-4), reflects that the sum of TP load reductions from NPS and PS in each zone (i), after implementing a BMP ( $k)$ and/or an AWT technology type $(m)$, needs to meet a pre-set TP load reduction target (Target_Pred). The second and third constraints, presented in Equations (4-5) and (4-6), are using a binary variable (0 or 1 ) to indicate if a BMP or an AWT technology was implemented or not. For instance, a value of 1 is used when a BMP type $(k)$ was adopted by NPS $(j)$ in zone (i), and 0 otherwise. 
The NPS BMP cost efficiency (TP load reductions and associated costs) were determined using estimates developed for the LOW for the three BMPs categories (i.e., owner, typical, and alternative) (SWET, 2006). These estimates were set on the basis of an extensive literature review, observed data, and modeling projects around Florida (SWET, 2008). Owner-type BMPs refer to nutrient management practices, such as reducing fertilizer application. Typical and alternative types of BMPs are structural practices involving the construction of more capital-intensive practices, such as adding structures that retain water on-site for longer periods of time or edge-of-field predischarge treatment systems (Bottcher et al., 1995). The PS AWT cost efficiency (TP load reductions and associated annual costs for a wide range of flow rates) were determined using values developed by USEPA (2008) examining different AWT retrofit technologies that involve modifying or making additions around an existing biological treatment system. The reported cost estimates were used to derive capital cost and operational and maintenance (O\&M) cost functions for two groups of technologies: medium effluent TP target (average TP concentration of $0.5 \mathrm{mg} \mathrm{L}^{-1}$ ) and low effluent TP target (average TP concentration of $0.1 \mathrm{mg} \mathrm{L}^{-1}$ ). These two groups were selected on the basis of the fact that the performance of the treatment processes at the WWTFs, evaluated in the USEPA (2008) study, could reach mid-level TP concentrations (between 0.1 to 0.5 $\mathrm{mg} \mathrm{L}^{-1}$ ) or low TP concentrations (less than $0.1 \mathrm{mg} \mathrm{L}^{-1}$ ). Table $4-3$ presents TP reduction efficiencies and unit annual costs (\$ per kilogram of TP removed) for agricultural and urban BMPs, and for AWT retrofit technologies used in this study. All costs were indexed to 2012 dollars using the Consumer Price Index inflation calculation. 


\section{Command-and-control approach}

A command-and-control (CAC), also known as a conventional approach, is when a regulatory agency outlines specific effluent water quality standards or particular control technologies that are deemed to be protective for impaired waterbodies and their designated uses (Field and Field, 2006). In the present study, the CAC approach represents the baseline (no-trading) scenario to which the WQTP would be compared to in order to evaluate the potential economic benefits in each sub-watershed. Under the CAC approach, the TP water quality goal for each sub-watershed was allocated for PS, using the total TP amount that would be discharged if an AWT technology was adopted in each WWTF to reach an end-of-pipe effluent target TP concentration of $0.1 \mathrm{mg} \mathrm{L}^{-1}$. For NPS, the allocation was defined as the difference between the water quality goal and the PS allocation. The allocated TP load allocation was then distributed among all NPS

depending on the land aerial coverage; the resulting load per hectare $\left(\mathrm{kg} \mathrm{P} \mathrm{ha}^{-1} \mathrm{yr}^{-1}\right)$ represents the maximum TP load rate allowed to be discharged from different NPS types. Therefore, while the maximum TP load allowed to be discharged from PS remains fixed under this abatement approach, the TP load permitted from NPS is dependent on the preset sub-watershed water quality goal. As opposed to the LCA approach, the selection of management alternatives applied to each source is reliant on the best available BMP or technology to comply with an individual TP load allocation.

\subsubsection{Setting the cap of a water quality trading program through an optimization process}

The cap is generally defined as the maximum pollutant amount allowed to be discharged from all trading sources in an impaired watershed for a given period of time. 
The cap can be defined in terms of load, concentration, or percent reduction targets. In theory, the most economically efficient level for the emission cap implies a balance between abatement costs and damages (Field and Field, 2006). However, it is often the case that environmental damages are difficult to measure accurately. Therefore, in practice, policymakers determine the cap level by considering a combination of factors, such as cost-effectiveness, fairness, and political feasibility.

In the present study, different caps were evaluated and their implications on the market potential were analyzed while evaluating four different factors: 1) least-cost abatement solutions, 2) credit price derived from a market supply curve, 3) potential cost savings of the LCA scenario in comparison with the CAC approach, and 4) supply and demand of credits. The selection of the cap level affects each of these factors which in turn would ultimately influence the efficiency of a WQTP for meeting certain TP loading abatement levels. An optimization process was developed using these factors to select the most appropriate cap for each of the studied sub-watersheds in order to have a viable and sustainable TP trading program.

For comparison purposes, trading scenarios were developed using the optimal TP caps selected for each sub-watershed. For each trading scenario, the buyer and seller sources were identified, credit prices and the amount of trades were estimated, cost of credits for individual sources were assessed while considering TRs and transaction fees, and finally the overall WQTP cost savings relative to a CAC approach were evaluated. A $10 \%$ of the credit price was added to the cost of the credits as a transaction fee in order to account for the time and resources needed to implement a trade (e.g., information gathering, negotiation, execution, and monitoring). 


\subsection{Results and Discussion}

\subsubsection{Phosphorus loads by source}

\section{Upper Kissimmee sub-watershed}

Annual average TP load values estimated at the source (cell) level, attenuated to the nearby stream, and attenuated to the outlet of the UK sub-watershed are reported in Table 4-4. The total TP loads generated at the source level were 268.6 mtons $\mathrm{yr}^{-1}$ (55\%) and 217.2 mtons $\mathrm{yr}^{-1}$ (45\%), from NPS and PS, respectively, for a combined total TP load of 485.9 mtons $\mathrm{yr}^{-1}$ in the runoff. Sod farms, field crops, and ornamental land uses had the highest TP fluxes per hectare at the farm level with 8.1, 5.2, and $3.9 \mathrm{~kg} \mathrm{ha}^{-1} \mathrm{yr}^{-1}$, respectively. The same range of values was found in other studies reporting TP loads at the farm level of 6.6, 1.5, and $2.4 \mathrm{~kg} \mathrm{ha}^{-1} \mathrm{yr}^{-1}$, respectively for the same land use types in South Florida (He et al., 2014). Citrus, improved pastures, and urban land uses had TP fluxes of $0.6,1.5$, and $1.1 \mathrm{~kg} \mathrm{ha}^{-1} \mathrm{yr}^{-1}$, respectively, which are values comparable to the ones reported by Boggess et al. (1995). Figure 4-5a depicts the spatial distribution of the TP fluxes at the source level and the location of hotspot areas within the UK subwatershed. The total annual average TP loads from all sources (including natural areas) reaching the nearby stream and the sub-watershed outlet were 111.2 and 99 mtons $\mathrm{yr}^{-1}$, respectively (Table 4-4). The average monitored TP loading (obtained from the SFWMD DBHYDRO database) at the S-65 structure for the same time period (2002 - 2009) was about 105 mtons $\mathrm{yr}^{-1}$, close to the modeled value of 99 mtons $\mathrm{yr}^{-1}$. The TP sources, such as WWTFs, urban areas, and improved pastures had the highest TP load contribution to the outlet of the UK sub-watershed, accounting for 20.2, 19.6, and $16.3 \%$ of the total TP loading, respectively. It is worth mentioning that since TP loadings leaving the UK sub- 
watershed flow through the downstream Lower Kissimmee (LK) sub-watershed before reaching LO, a downstream attenuation factor of $30 \%$ was used to estimate the TP loading contribution from UK sub-watershed reaching the lake. The downstream attenuation factor, taken from the FDEP (2014) report, reflects the overland and in-stream attenuation associated to the LK sub-watershed. Hence, the total TP loading contribution from the UK sub-watershed reaching LO was 69.3 mtons $\mathrm{yr}^{-1}$.

\section{Taylor Creek/Nubbin Slough sub-watershed}

Annual average TP load values from NPS and PS are presented in Table 4-5 for the TCNS sub-watershed. The NPS TP loads simulated at the source level were 110.5 mtons $\mathrm{yr}^{-1}$. Improved pastures, covering almost $47 \%$ of the study area, were the major TP source accounting for $46.3 \%$ (69.4 mtons $\left.\mathrm{yr}^{-1}\right)$ of the total TP load discharged at the source level. In addition, TP loads from CAFOs represented 26\% (39.3 mtons $\left.\mathrm{yr}^{-1}\right)$ of the total TP loading generated at the source level. The CAFOs had the highest TP load rate per area at the source level with $9.9 \mathrm{~kg} \mathrm{ha}^{-1} \mathrm{yr}^{-1}$, followed by ornamentals and field crop land uses with 8.0 and $5.9 \mathrm{~kg} \mathrm{ha}^{-1} \mathrm{yr}^{-1}$, respectively. These TP values were consistent with estimates reported in a previous study conducted by Corrales et al. (2014) in the S-191 basin, where TP fluxes at the source level were 10.5, 9.0, and $5.9 \mathrm{~kg} \mathrm{ha}^{-1} \mathrm{yr}^{-1}$ for dairy, ornamentals, and field crop land use types, respectively. The TP fluxes of citrus, improved pastures, and sod land uses were also consistent with values reported by He et al. (2014) of 0.7, 1.5, and $6.6 \mathrm{~kg} \mathrm{ha}^{-1} \mathrm{yr}^{-1}$, respectively. The red areas depicted in Figure 4-5b indicate the location of the areas with the highest TP fluxes. The total annual average TP loads from all sources (including natural areas) reaching the nearby stream and the sub-watershed outlet were 124.9 and 115.7 mtons $\mathrm{yr}^{-1}$, respectively. The average monitored TP loading 
(obtained from the SFWMD DBHYDRO database) at the S-191 structure for the same

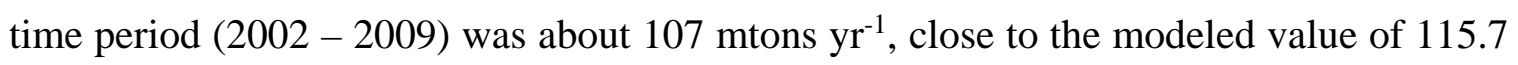
mtons $\mathrm{yr}^{-1}$. Downstream attenuation was not considered in this sub-watershed, since it directly discharges into LO.

In order to develop the two phosphorus abatement approaches (LCA and CAC), TP loadings generated from natural sources (significantly important in the UK subwatershed) were not considered in the comparison analysis. Therefore, the TP loadings set as the baseline before BMP and AWT implementation were 78.7 and 120 mtons $\mathrm{yr}^{-1}$ for the UK and TCNS sub-watersheds, respectively.

\subsubsection{Attenuation rates and delivery trading ratios}

There was a significant difference in the TP load attenuation from the source level to the nearby hydrologic unit in both sub-watersheds. On average, there was an overland attenuation of 77 and $17 \%$ for the UK and TCNS studied areas, respectively (Tables 4-4 and 4-5).This dissimilarity could be attributed to the high phosphorus assimilation capacity of natural areas, such as wetlands (Boggess et al., 1995), which are the most predominant land use types within the UK sub-watershed. TP loads were further assimilated or retained through reaches and canals by physical and chemical factors before reaching the outlet of the sub-watershed. Zones with different in-stream attenuation factors are presented in Figure 4-6. Areas close to the outlet of the two subwatersheds had relatively low attenuation factors (an average of $2 \%$ ), while some upstream areas yielded relatively high attenuation factors (an average of $20 \%$ for UK and 29\% for TCNS). The in-stream attenuation averages were 11 and 7\%, respectively for the UK and TCNS sub-watersheds, coinciding with assimilation rates, ranging from $2-20 \%$, 
reported by SWET (2008) for canals and stream conveyance systems in the St. Lucie and Caloosahatchee River watersheds (FL, USA). In addition, He et al. (2014) reported average overall (land and stream) assimilation rates of 74 and 33\%, agreeing with the values found in this study of 88 and $24 \%$ for the UK and TCNS sub-watersheds, respectively.

The resulting delivery TRs ranged from $0.82-1.23$ and from $0.72-1.38$ for the UK and TCNS sub-watersheds, respectively. Other studies have also used water quality models to quantify delivery TRs. For instance, FDEP (2010) used the Pollution Load Screening Model (PLSM) to estimate location factors, ranging from $0.01-1.7$, in the Lower St. Johns River basin (FL, USA). TRs were then used to develop trading scenarios to estimate the amount of credits a buyer would need to purchase in order to offset a required TP load reduction. A TR less than 1 was used when a buyer purchased credits from a seller located downstream. Whereas a TR higher than 1 was used when the seller was located upstream of the buyer's location. Therefore, from an economic perspective, a buyer would be more interested to trade credits with a source situated downstream, thereby increasing the demand of credits generated from sources closer to the discharge outlet of the sub-watersheds.

\subsubsection{Setting the cap of a WQTP scenario in the UK and TCNS sub-watersheds}

The TMDL adopted for an impaired waterbody is generally used for setting the cap of a WQTP as a legal binding mechanism to incentivize regulated sources to seek credits in a market (Ribaudo and Gottlieb, 2011). Despite this policy driver, an overall low trading activity has been observed in the majority of the WQTPs. The success of a WQTP relies heavily on setting the correct binding obligation that can either encourage or hinder the 
participation of trading sources in a credit trading market. For instance, Hamstead and BenDor (2010) reported that setting a low-level cap for the Neuse River Basin Total Nitrogen Trading program (NC, USA) was one of the causes of low-trade activity, since facilities were able to reduce nitrogen loads to compliance levels by technological improvements implemented on-site. Likewise, stringent caps would leave little room to provide additional reductions to generate credits, because all available abatement measures would be already implemented to comply with the cap.

Four factors were considered in this study to determine the most suitable cap (or reduction target) for a WQTP in each of the sub-watersheds: total annual abatement costs, credit prices, potential cost savings, and credits supply and demand.

\section{Total annual abatement costs}

The total annual costs (in million dollars) incurred from all trading sources when implementing the least-cost BMP or technology for achieving different sub-watershed TP load reduction targets are presented in Figures 4-7a and 4-7b for the UK and TCNS subwatersheds, respectively. Overall, the total annual costs for the UK sub-watershed were five times higher than the costs for the TCNS sub-watershed for the same TP reduction levels. Figure 4-7 indicates that the total costs and reduction targets are positive correlated, reaching total annual costs of \$ 327.9 and \$ 50.3 million for the highest TP load reduction of 75 and $66 \%$ achieved for the UK and TCNS sub-watersheds, respectively. Figure 4-7a denotes no significant change in the total cost for TP reduction targets ranging from $5-50 \%$ for the UK sub-watershed. However, once the reduction targets exceeded 50\%, a substantial increase in the total cost occurred. A similar pattern was observed in the TCNS sub-watershed for TP reduction targets greater than $60 \%$ 
(Figure 4-7b). Therefore, in order to develop trading scenarios while keeping the optimal cost-effectiveness of the program, TP reduction targets lower than 50 and $60 \%$ had to be selected as the WQTP caps for the UK and TCNS sub-watersheds, respectively.

\section{Credit prices}

Figure 4-8, representing the aggregated supply curves, illustrate the positive relationship linking the credit prices and the TP load reduction. Since each point on the supply curves corresponds to an equilibrium state between the supply and demand of credits, Figure 4-8 also depicts the credit price that trading sources would be willing to pay for an additional TP reduction unit. Credit prices in the UK sub-watershed varied significantly from \$ 27 per kilogram for a 5\% TP reduction to \$ 7,151 per kilogram for the maximum TP reduction of $75 \%$. On the other hand, credit prices in the TCNS subwatershed ranged from \$ 13 per kilogram for a 5\% TP reduction to \$2,216 per kilogram for the maximum TP reduction of $66 \%$. Implemented WQTPs, such as the Great Miami River Watershed Trading Pilot program (OH, USA), the Lower St. Johns River Pilot Water Quality Trading program (FL, USA), and the South Nation River Watershed Trading program (Canada) reported credit prices of \$ 28, \$ 152, and \$ 410 per kilogram of TP removed, respectively (Corrales et al., 2013). The market price of the credits can vary greatly depending on the type of sources or sectors included in the program (Sado et al., 2010). For instance, in the UK sub-watershed (dominated by urban areas) the credit price for achieving a 50\% TP load reduction was about \$1000, whereas in the TCNS sub-watershed (dominated by agricultural areas) the credit price was close to $\$ 500$ for the same TP reduction level. 
Figure 4-8a also indicates that the knee-of-the-curve fell at the 50\% TP reduction level. Indeed, the credit price increased twofold and sevenfold when TP reduction targets increased from $50-60 \%$ and from $50-75 \%$, respectively. In the case of the TCNS subwatershed (Figure 4-8b), the knee-of-the-curve fell at the $40 \%$ TP reduction level, since the credit price increased twofold and fivefold when TP reduction targets increased from $40-50 \%$ and from $40-65 \%$, respectively. Therefore, in order to develop trading scenarios, while keeping an optimal credit price of the program, TP reduction targets lower than 50 and $40 \%$ had to be selected as the WQTP caps for the UK and TCNS subwatersheds, respectively.

\section{Potential cost savings}

The cost-effectiveness (i.e., achieving a given level of environmental improvement at the least possible cost) of the two TP control approaches (CAC and LCA) was evaluated to select an optimal cap for the WQTPs. The cost-effectiveness is an important criterion helping policymakers to select pollution control instruments (Goulder and Parry, 2008). Tables 4-6 and 4-7 provide cost comparison of the LCA and CAC approaches for achieving different TP reduction levels for the UK and TCNS sub-watersheds, respectively. Abatement costs ranged from $5-86 \%$ and from $5-58 \%$ lower under the LCA approach than under the CAC scenario in the UK and TCNS sub-watersheds, respectively. These results illustrate the cost advantage that incentive-based policies offer over conventional approaches. However, the cost advantage decreased as TP reduction targets became more stringent, because at high TP reduction levels fewer abatement alternatives were available to meet the pre-set cap. It would be economically reasonable to set the cap of a WQTP at the level where trading sources would have the most 
economic benefits or savings with respect to other emission control alternatives (Ravesz and Stavins, 2004). In the present study, this level was reached when the difference in total abatement costs between the LCA and CAC approaches was maximized. In the case of the UK sub-watershed (Table 4-6), the highest potential cost savings (\$127.2 million $\mathrm{yr}^{-1}$ ) were reached for a TP reduction target of $56 \%$. In the case of the TCNS subwatershed (Table 4-7), the highest potential cost savings ( $\$ 4.0$ million $\mathrm{yr}^{-1}$ ) were attained for a TP reduction target of $30 \%$.

\section{Credit supply and demand}

Generating enough credit supply and demand is an important factor in a WQTP since it is a measure of the degree of competition in the market. In thin markets, with a few buyers or sellers, competitive pressures are weak or absent, giving the small group of buyers or sellers to exercise control over the market (Field and Field, 2006). In addition, a WQTP with few traders could bring several issues related to high transaction costs, price volatility, and willingness to participate (USEPA, 2003a). Tables 4-8 and 4-9 present the number of credits available to be sold in the market and the number of potential buyers and sellers in the UK and TCNS sub-watersheds, respectively. Potential credit buyers were identified whenever TP loadings under the LCA approach were higher than those obtained under the CAC approach. On the other hand, sources discharging below their CAC load were identified as potential credit sellers. An inverse relationship between the TP reduction target and the number of potential sellers was observed. Hence, WQTPs become a seller-dominated market with more stringent caps. The potential for the creation of thin markets was more evident in the UK sub-watershed since there were only two potential buyers identified at a TP reduction target of $56 \%$ and one potential buyer at 
a TP reduction target of $61 \%$. In this sub-watershed, a large and almost equal number of buyers and sellers was observed for a TP reduction level of $46 \%$, thus creating a competitive market scenario. In the case of the TCNS sub-watershed, the potential volume of trades was comparable for all TP reduction levels.

Integrating the four factors influencing the cap level (Figure 4-9) and in order to foster competition for a viable and sustainable trading program in the two studied areas, TP reduction targets of 46 and 32\% were selected as the most appropriate reduction levels for the UK and TCNS sub-watersheds, respectively.

\subsubsection{Comparing CAC and LCA scenarios}

Figure 4-10 illustrates the combination of BMPs and AWT technologies that were selected under the CAC approach (Figure 4-10a) and under the LCA approach (Figure 4$10 \mathrm{~b}$ ), in order to meet the $46 \%$ TP reduction target in the UK sub-watershed. Under the CAC approach, citrus, improved pastures, and rangeland and wooded pastures (across all zones in this sub-watershed) were either already in compliance with their individual allocations or were supposed to implement BMP types I or II (i.e., owner and typical types of BMPs, respectively). In contrast, under the optimized LCA approach, these sources were selected to implement additional TP load reduction efforts given their low marginal abatement cost relative to other pollution sources. On the other hand, WWTFs, sod farms, and urban areas were selected to implement less expensive technologies and management practices under the LAC approach, and bought credits from other sources to reach their load allocations.

Figure 4-11 shows the BMP types that each pollution source needed to implement (across all zones) under the two TP abatement approaches, in order to meet the 
aggregated TP load reduction target of 32\% for the TCNS sub-watershed. Under the CAC approach (Figure 4-11a), citrus, sugarcane, and urban areas were already in compliance with their individual allocations, whereas CAFOs, field crops, and ornamentals had to implement the most advanced alternative type of BMP (BMP III) to reach their individual TP load requirements. Under the LCA optimized approach (Figure 4-11b), citrus, sugarcane, and urban areas were selected to reduce their TP loads beyond their baseline by implementing BMP type I with minimal additional costs. On the other hand, CAFOs and ornamentals reduced their annual investment by implementing BMP types I and II, instead of the more capital intensive BMP type III required under the CAC approach.

Table 4-10 lists the credit prices, number of credits traded, and net cost savings estimated for the WQTP scenarios developed in the two studied areas using the selected TP load reduction targets. Credit prices were of \$ 673 and \$ 130 per kilogram of TP reduced for the UK and TCNS sub-watersheds, respectively. The number of credits traded was 73\% (4,601 credits) and 50\% (10,495 credits) of the total available TP credits for the UK and TCNS sub-watersheds, respectively. In the UK sub-watershed, the major sellers were improved and unimproved pastures, and the major buyers were the WWTFs and urban areas, selling and purchasing 84 and $76 \%$ of the total credits traded, respectively. In the TCNS sub-watershed, improved pastures and CAFOs dominated the market as sellers and buyers of 94 and 86\% of the credits traded, respectively. Although sellers incurred an additional cost of \$ 2.1 and \$ 1.0 million for implementing more BMPs in the UK and TCNS sub-watersheds, respectively, they sold credits for \$ 3.1 and \$ 1.4 million, representing an annual cost savings of \$ 956,625 in the UK and \$ 337,778 in the TCNS sub-watersheds. Even with the transaction fees, the annual cost savings were 
higher for buyers participating in the trading program, representing 97 and $89 \%$ of the total cost savings for the UK and TCNS sub-watersheds, respectively. The estimated net cost savings resulting from implementing a WQTP in the UK and TCNS sub-watersheds were 76\% (\$ 34.9 million per year) and 45\% (\$ 3.2 million per year), respectively. Feasibility assessments of the potential of a WQTP in other watersheds have yielded similar percentages of potential cost savings. For instance, Faeth (2000) investigated the potential for trading in three upper Midwest states (Michigan, Wisconsin, and Minnesota) and found in each case cost savings of between 43 and $88 \%$ to meet or exceed water quality targets, compared to more stringent point source performance requirements. In addition, Van Houtven et al. (2012) estimated potential cost savings of $82 \%$ for the Chesapeake Bay watershed when considering a nutrient trading scenario over a notrading scenario. In addition, the net cost savings estimated in this study were higher than the net cost savings obtained by Corrales et al. (2014), a study conducted in a small area in LOW (S-191 basin). Thus, the cost savings generated from a WQTP generally increases when the geographic boundary of the program is extended and more diverse sources are included (Newell and Stavins, 2003; Van Houtven et al., 2012). Nevertheless, it is worth mentioning that the market suitability and financial attractiveness of a WQTP could vary depending on the market structure established to facilitate trading (Ribaudo and Gottlieb, 2011; Woodward et al., 2002), risk perceptions of pollution sources (Hamstead and BenDor, 2010; Horan, 2001), on trusted and effective relationships among regulatory agencies, public sector, and other stakeholders (Newburn and Woodward, 2012), and on the specific trading rules determined by regulators (Horan and Shortle, 2011). 


\subsection{Conclusions}

This study explored the environmental and economic feasibility of a WQTP over a CAC approach in two sub-watersheds within the LOW. The Upper Kissimmee (UK) and the Taylor Creek/Nubbin Slough (TCNS) studied areas were selected since the two sub watersheds are a major TP loading source discharging into LO. Sod farms and CAFOs were identified as the major sources of TP load per area (at the source level) in the UK and TCNS sub-watersheds, respectively. Furthermore, delivery TRs of $0.98-1.23$ for UK and $0.72-1.38$ for TCNS were set using the attenuation rates estimated with the hydrologic and water quality WAM model. The financial feasibility of the WQTP was assessed while evaluating the effect of different TP caps on the potential for a credit market in each of the two sub-watersheds. Four factors influencing the selection of the cap were analyzed: total abatement costs under the least-cost solution, credit price, potential cost savings, and credit supply and demand. While attaining cost-effectiveness, keeping optimal credit prices, and fostering market competition, TP reduction targets of 46 and 32\% were selected as the most appropriate TP caps, in order to develop a viable and sustainable trading scenario in the UK and TCNS sub-watersheds, respectively. The estimated net cost savings resulting from implementing a WQTP in the UK and TCNS sub-watersheds were 76\% (\$ 34.9 million per year) and 45\% (\$3.2 million per year), respectively. Buyer sources, such as WWTFs and urban areas acquired $97 \%$ of the total cost savings estimated through trading in the UK sub-watershed. Likewise, $89 \%$ of the total estimated cost savings in the TCNS were attributed to offsetting CAFOs TP loading requirements from other sources. While the results of this study are promising, the realization of the environmental and economic benefits of this market-based alternative is 
also contingent on other important factors such as the market structure, the specific program rules, the risk perception, and the education and outreach to develop trusted relationships among regulatory agencies, the public sector, and other stakeholders. Nevertheless, this study provided some critical results to facilitate the development of pilot WQTPs in the LOW and to better understand the potential economic opportunities that TP sources would have by participating in a WQTP.

\subsection{References}

Abtew, W., Ciuca, V., 2015. Chapter 2: South Florida hydrology and water management, South Florida Environmental Report, South Florida Water Management District, West Palm Beach, FL.

Boggess, C.F., Flaig, E.G., Fluck, R.C., 1995. Phosphorus budget-basin relationships for Lake Okeechobee tributary basins, Ecol. Eng. 5, 143-162.

Bottcher, A.B., Tremwel, T.K., Campell, K.L., 1995. Best management practices for water quality improvement in the Lake Okeechobee watershed, Ecol. Eng. 5, 341356.

Collentine, D., 2006. Composite market design for a transferable discharge permit (TDP) system, Journal of Environmental Planning and Management 49, 929-946.

Corrales, J., Naja, G.M., Bhat, M.G., Miralles-Wilhelm, F., 2014. Modeling a phosphorus credit trading program in an agricultural watershed, J. Environ. Manage. 143, 162172.

Corrales, J., Naja, G.M., Rivero, R.G., Miralles-Wilhelm, F., Bhat, M.G., 2013. Water Quality Trading Programs Towards Solving Environmental Pollution Problems, Irrig. Drain. 62, 72-92.

Crites, R.W., Bastian, R.K., Reed, S.C., 2000. Land treatment systems for municipal and industrial wastes. McGraw-Hill, New York, NY.

Evanylo, G., Ervin, E., Zhang, X., 2010. Reclaimed water for turfgrass irrigation, Water 2, 685-701.

FDEP, 2014. Basin management action plan for the Implementation of total maximum daily loads for total phosphorus by the Florida Department of Environmental 
Protection in Lake Okeechobee, Florida Department of Environmental Protection, Tallahassee, FL.

FDEP, 2001. Total maximum daily load for total phosphorus Lake Okeechobee, Florida, Florida Department of Environmental Protection, Atlanta, GA.

FDEP, 2015. Consolidated OCULUS electronic document management system, Florida Department of Environmental Protection, Retrieved January, 2015, from http://depedms.dep.state.fl.us/Oculus/servlet/login.

Feng, H., Jha, M., Gassman, P., 2009. The allocation of nutrient load reduction across a watershed: Assessing delivery coefficients as an implementation tool, Review of Agricultural Economics 31, 183-204.

Field, B.C., Field, M.K., 2006. Environmental economics: An introduction, Fourth edition ed. McGraw-Hill/Irwin, New York, NY.

Goulder, L.H., Parry, I.W.H., 2008. Instrument choice in environmental policy, Review of Environmental Economics and Policy 2, 152-174.

Hamstead, Z.A., BenDor, T.K., 2010. Overcompliance in water quality trading programs: findings from a qualitative case study in North Carolina, Environment and Planning C: Government and Policy 28, 1-17

Havens, K., Gawlik, D., 2005. Lake Okeechobee conceptual ecological model, Wetlands 25, 908-925.

He, Z., Hiscock, J.G., Merlin, A., Hornung, L., Liu, Y., Zhang, J., 2014. Phosphorus budget and land use relationships for the Lake Okeechobee Watershed, Florida, Ecol. Eng. 64, 325-336.

Hiscock, J., Thourot, C., Zhang, J., 2003. Phosphorus budget - land use relationships for the northern Lake Okeechobee watershed, Florida, Ecol. Eng. 21, 63-74.

Horan, R.D., 2001. Differences in social and public risk perceptions and conflicting impacts on point/nonpoint trading ratios, Am. J. Agric. Econ. 83, 934-941.

Horan, R.D., Shortle, J.S., 2011. Economic and ecological rules for water quality trading, J. Am. Water Resour. Assoc. 47, 59-69.

Jarvie, H.P., Sharpley, A.N., Withers, P.J.A., Scott, J.T., Haggard, B.E., Neal, C., 2013. Phosphorus mitigation to control river eutrophication: murky waters, inconvenient truths, and "postnormal" science, J. Environ. Qual. 42, 295-304. 
Lal, H., Delgado, J.A., Gross, C.M., Hesketh, E., McKinney, S.P., Cover, H., Shaffer, M., 2009. Market-based approaches and tools for improving water and air quality, Environmental Science and Policy 12, 1028-1039.

Newburn, D.A., Woodward, R.T., 2012. An ex post evaluation of Ohio's Great Miami water quality trading program, J. Am. Water Resour. Assoc. 48, 156-169.

Newell, R., Stavins, R., 2003. Cost heterogeneity and the potential savings from marketbased policies, Journal of Regulatory Economics 23, 43-59.

Ravesz, R.L., Stavins, R.N., 2004. Environmental law and public policy, RFF DP 04-30 REV, Resources for the Future, Washington, DC.

Ribaudo, M., Gottlieb, J., 2011. Point-nonpoint trading - Can it work?, J. Am. Water Resour. Assoc. 47, 5-14.

Sado, Y., Boisvert, R.N., Poe, G.L., 2010. Potential cost savings from discharge allowance trading: A case study and implications for water quality trading, Water Resour. Res. 46, W02501.

SFWMD, 2014. GIS data catalog, South Florida Water Management District, Retrieved January 2014, from http://www.sfwmd.gov/gisapps/sfwmdxwebdc/dataview.asp?.

SFWMD, FDEP, FDACS, 2011. Lake Okeechobee protection plan update, South Florida Water Management District, Florida Department of Environmental Protection, Florida Department of Agriculture and Consumer Services, West Palm Beach, FL.

Sharfstein, B., Zhang, J., Bertolotti, L., 2015. Chapter 8: Lake Okeechobee watershed protection program annual update, South Florida Environmental Report, South Florida Water Management District, West Palm Beach, FL.

Shortle, J.S., Horan, R.D., 2006. Water quality trading, Penn State Environmental Law Review 14, 231-250.

SWET, 2011. Watershed assessment model documentation, Soil and Water Engineering Technology, Inc., Gainesville, FL.

SWET, 2008. Final report: Nutrient loading rates, reduction factors and implementation costs associated with BMPs and technologies, Soil and Water Engineering Technology, Inc., Gainesville, FL.

SWET, 2006. Letter report entitled: Phosphorus reduction performance and implementation costs under BMPs and technologies in the Lake Okeechobee protection plan area, Soil and Water Engineering Technology, Inc., Gainesville, FL. 
USEPA, 2008. Municipal nutrient removal technologies reference document: Volume 1 technical report, EPA 832-R-08-006, U.S. Environmental Protection Agency, Washington, DC.

USEPA, 2003a. Tools of the trade: A guide to designing and operating a cap and trade program for pollution control, EPA430-B-03-002, U.S. Environmental Protection Agency, Washington, DC.

USEPA, 2003b. Wastewater technology fact sheet, EPA 832-F-03-025, U.S. Environmental Protection Agency, Washington, DC.

USEPA, 2003c. Water quality trading assessment handbook: EPA region 10's guide to analyzing your watershed, EPA 910-B-03-003, U.S. Environmental Protection Agency, Washington, DC.

Van Houtven, G., Loomis, R., Baker, J., Beach, R., Casey, S., 2012. Nutrient credit trading for the Chesapeake Bay: An economic study, RTI International, Research Triangle Park, NC.

Woodward, R.T., Kaiser, R.A., Wicks, A.B., 2002. The structure and practice of water quality trading markets, J. Am. Water Resour. Assoc. 38, 967-979.

Zhang, J.L., Li, Y.P., Wang, C.X., Huang, G.H., 2015. An inexact simulation-based stochastic optimization method for identifying effluent trading strategies of agricultural nonpoint sources, Agricultural Water Management 152, 72-90.

Zhang, J., Ray, S.A.F., Steinman, A., 2002. Potential phosphorus load reductions under the Lake Okeechobee regulatory program, J. Am. Water Resour. Assoc. 38, 16131624.

Zhao, H., Zhang, J., James, R.T., Laing, J., 2012. Application of MIKE SHE/MIKE 11 model to structural BMPs in S191 basin, Florida, Journal of Environmental Informatics 19, 10-19. 


\subsection{Tables}

Table 4-1. Land use data for Upper Kissimmee (UK) and Taylor Creek/Nubbin Slough (TCNS) sub-watersheds.

\begin{tabular}{lrrrr}
\hline & \multicolumn{2}{c}{ UK } & \multicolumn{2}{c}{ TCNS } \\
Land Use & $\begin{array}{c}\text { Area } \\
\text { (ha) }\end{array}$ & $\begin{array}{c}\text { Percent } \\
\text { (\%) }\end{array}$ & $\begin{array}{c}\text { Area } \\
\text { (ha) }\end{array}$ & $\begin{array}{c}\text { Percent } \\
\text { (\%) }\end{array}$ \\
\hline Citrus & 23,088 & $5.6 \%$ & 1,483 & $1.9 \%$ \\
Improved Pastures & 53,444 & $12.9 \%$ & 37,110 & $47.2 \%$ \\
Unimproved Pastures & 11,893 & $2.9 \%$ & 1,982 & $2.5 \%$ \\
Rangeland and Wooded Pasture & 2,328 & $0.6 \%$ & 283 & $0.4 \%$ \\
Dairies & 36 & $0.0 \%$ & 3,978 & $5.1 \%$ \\
Field Crops & 636 & $0.2 \%$ & 1,756 & $2.2 \%$ \\
Ornamentals & 232 & $0.1 \%$ & 502 & $0.6 \%$ \\
Row Crops & 1,394 & $0.3 \%$ & 213 & $0.3 \%$ \\
Sod & 3,653 & $0.9 \%$ & 1,311 & $1.7 \%$ \\
Sugarcane & - & $0.0 \%$ & 3,649 & $4.6 \%$ \\
Urban & 87,881 & $21.2 \%$ & 10,444 & $13.3 \%$ \\
Natural Areas & 230,409 & $55.5 \%$ & 15,834 & $20.2 \%$ \\
\hline Total & $\mathbf{4 1 4 , 9 9 4}$ & $\mathbf{1 0 0 . 0 \%}$ & $\mathbf{7 8 , 5 4 5}$ & $\mathbf{1 0 0 . 0 \%}$ \\
\hline
\end{tabular}

Table 4-2. Description of the variables used in the optimization model.

\begin{tabular}{clc}
\hline Symbol & \multicolumn{1}{c}{ Description } & Units \\
\hline$i$ & Set of sub-watershed zones with different percent of attenuation \\
$j$ & Set of land uses representing NPS (agricultural and urban sources) & \\
$k$ & Set of best management practices (BMPs) types to apply in NPS \\
$n$ & Set of wastewater treatment facilities (WWTFs) representing PS \\
$m$ & Set of advanced wastewater treatment (AWT) technologies types to apply & \\
& in PS & \\
$c_{i, k, j}$ & Annual cost of implementing a BMP $(k)$ at a NPS $(j)$ in zone $(i)$ & $\$ \mathrm{yr}^{-1}$ \\
$c_{i, m, n}$ & Annual cost of implementing an AWT technology $(m)$ at PS $(n)$ in zone $(i)$ & $\$ \mathrm{yr}^{-1}$ \\
$X_{i, k, j}$ & Binary variable with a value of 1 if a BMP $(k)$ is implemented, 0 otherwise & - \\
$Y_{i, k, j}$ & Binary variable with a value of 1 if an AWT technology $(m)$ is & - \\
& implemented, 0 otherwise & \\
$r_{k, j}$ & Percent TP load reduction attained when implementing a BMP $(k)$ at NPS & \\
& P) & \\
$r_{m, n}$ & Percent TP load reduction attained when applying an AWT technology type & \\
$L_{i, j}$ & Current TP load from NPS $(j)$ located in zone $(i)$ at the zone level & $\mathrm{kg} \mathrm{yr}^{-1}$ \\
$L_{i, n}$ & Current TP load from PS $(n)$ located in zone $(i)$ at the zone level & $\mathrm{kg} \mathrm{yr}^{-1}$ \\
Target_P $P_{\text {red }}$ & TP load reduction from NPS and PS at the zone level when following the & $\mathrm{kg} \mathrm{yr}^{-1}$ \\
\hline
\end{tabular}

NPS: Nonpoint sources; PS: Point sources; TP: Total phosphorus. 
Table 4-3. Best management practices (BMPs) and advanced wastewater treatment (AWT) technologies total phosphorus (TP) reduction efficiencies (\%) and annual unit costs (\$ kg-1 reduced) for Upper Kissimmee (UK) and Taylor Creek/Nubbin Slough (TCNS) sub-watersheds.

\begin{tabular}{|c|c|c|c|c|}
\hline & & \multicolumn{2}{|r|}{ UK } & TCNS \\
\hline & & $\begin{array}{l}\text { Reduction } \\
\text { Efficiency } \\
\quad(\%)\end{array}$ & \multicolumn{2}{|c|}{$\begin{array}{c}\text { Unit Cost } \\
\text { (\$ kg-1 reduced) }\end{array}$} \\
\hline \multicolumn{5}{|c|}{ Agricultural BMPs* } \\
\hline BMP I & $\begin{array}{l}\text { Reduce phosphorus fertilization, } \\
\text { better nutrient management, grass } \\
\text { management }\end{array}$ & $4-30 \%$ & $\$ 0-828$ & $\$ 0-76$ \\
\hline BMP II & $\begin{array}{l}\text { Stormwater } \mathrm{R} / \mathrm{D} \text {, wetland } \\
\text { restoration, water management, } \\
\text { rotational grazing, new water } \\
\text { facilities, critical area fencing }\end{array}$ & $10-65 \%$ & $\$ 99-33,811$ & $\$ 24-883$ \\
\hline BMP III & $\begin{array}{l}\text { Edge-of-farm stormwater R/D } \\
\text { and chemical treatment }\end{array}$ & $40-85 \%$ & $\$ 204-28,461$ & $\$ 49-1,537$ \\
\hline \multicolumn{5}{|c|}{ Urban BMPs* } \\
\hline BMP I & $\begin{array}{l}\text { Reduce phosphorus fertilization } \\
\text { Limited dry retention, street }\end{array}$ & $5 \%$ & $\$ 0$ & $\$ 0$ \\
\hline BMP II & $\begin{array}{l}\text { sweeping, sediment R/D and } \\
\text { wetland restoration }\end{array}$ & $10 \%$ & $\$ 18,349$ & $\$ 7,693$ \\
\hline BMP III & $\begin{array}{l}\text { Stormwater R/D and chemical } \\
\text { treatment }\end{array}$ & $73 \%$ & $\$ 18,601$ & $\$ 7,799$ \\
\hline \multicolumn{5}{|c|}{ WWTF AWT Technologies** } \\
\hline AWT I & $\begin{array}{l}\text { Fermenter retrofit, 1-point } \\
\text { chemical addition, fermenter with } \\
\text { sand filter }\end{array}$ & $50-87 \%$ & $\$ 115-612$ & - \\
\hline AWT II & $\begin{array}{l}\text { Fermenter with sand filter plus 1- } \\
\text { point chemical addition , 2-point } \\
\text { chemical addition }\end{array}$ & $90-98 \%$ & $\$ 219-945$ & - \\
\hline \multicolumn{5}{|c|}{$\begin{array}{l}\text { BMP I: Owner type BMP; BMP II: Owner and typical BMPs; BMP III: Owner, typical, and } \\
\text { alternative BMPs. } \\
\text { AWT I: Treatment technology reaching a target TP concentration of } 0.5 \mathrm{mg} \mathrm{L}^{-1} \text {; AWT II: Treatment } \\
\text { technology reaching a target TP concentration of } 0.1 \mathrm{mg} \mathrm{L}^{-1} \text {. } \\
\text { * Annual unit costs for agricultural and urban BMPs include amortized capital costs at } 10 \% \text { interest } \\
\text { over a } 20 \text {-year life span. The annual O\&M costs were determined using the } 20 \% \text { of the annualized } \\
\text { capital cost. } \\
\text { ** Annual unit costs for AWT technologies include the annualized capital and O\&M costs using an } \\
\text { amortization of } 6 \% \text { interest over a } 20 \text {-year life span for the capital costs. }\end{array}$} \\
\hline
\end{tabular}


Table 4-4. Average Annual Total Phosphorus (TP) load per source in the Upper Kissimmee (UK) sub-watershed.

\begin{tabular}{|c|c|c|c|c|}
\hline Source & $\begin{array}{l}\text { TP load at } \\
\text { the source } \\
\text { level } \\
\left(m \text { tons } \mathbf{y r}^{-1} \text { ) }\right.\end{array}$ & $\begin{array}{l}\text { TP load flux } \\
\text { at the source } \\
\left(\mathrm{kg} \mathrm{ha}^{-1} \mathrm{yr}^{-1}\right)\end{array}$ & $\begin{array}{c}\text { TP load } \\
\text { attenuated } \\
\text { to the } \\
\text { nearby } \\
\text { stream } \\
\left(\text { mtons yr }{ }^{-1} \text { ) }\right.\end{array}$ & $\begin{array}{c}\text { TP load } \\
\text { attenuated to } \\
\text { the outlet } \\
\left(\mathrm{mtons} \mathrm{yr}^{-1}\right)\end{array}$ \\
\hline \multicolumn{5}{|l|}{ Nonpoint Sources } \\
\hline Citrus & 10.9 & 0.5 & 3.7 & $3.2(3.2 \%)$ \\
\hline Improved pasture & 65.8 & 1.2 & 18.1 & $16.1(16.3 \%)$ \\
\hline Unimproved pasture & 7.4 & 0.6 & 2.7 & $2.4(2.4 \%)$ \\
\hline $\begin{array}{l}\text { Rangeland and } \\
\text { wooded pasture }\end{array}$ & 3.1 & 1.3 & 0.9 & $0.8(0.8 \%)$ \\
\hline Field crops & 3.3 & 5.2 & 0.7 & $0.6(0.7 \%)$ \\
\hline Ornamentals & 0.9 & 3.9 & 0.1 & $0.1(0.1 \%)$ \\
\hline Row crops & 3.9 & 2.8 & 1.3 & $1.2(1.2 \%)$ \\
\hline Sod & 29.7 & 8.1 & 6.5 & $5.9(6 \%)$ \\
\hline Urban & 71.6 & 0.8 & 22.2 & $19.4(19.6 \%)$ \\
\hline Natural areas & 72.1 & 0.3 & 32.5 & $29.0(29.3 \%)$ \\
\hline Sub-total & 268.6 & 0.6 & 88.7 & 79.0 (79.8\%) \\
\hline \multicolumn{5}{|l|}{ Point Sources } \\
\hline WWTFs & 217.2 & $\mathrm{n} / \mathrm{a}$ & 22.5 & $20.0(20.2 \%)$ \\
\hline Total & 485.9 & 0.6 & 111.2 & $99.0(100 \%)$ \\
\hline
\end{tabular}

WWTF: Wastewater treatment facilities. 
Table 4-5. Average Annual Total Phosphorus (TP) load per source in the Taylor Creek/Nubbin Slough (TCNS) sub-watershed.

\begin{tabular}{|c|c|c|c|c|}
\hline Source & $\begin{array}{l}\text { TP load at } \\
\text { the source } \\
\text { level } \\
\text { (mtons } \mathbf{y r}^{-1} \text { ) }\end{array}$ & $\begin{array}{l}\text { TP load flux } \\
\text { at the source } \\
\left(\mathrm{kg} \mathrm{ha}^{-1} \mathrm{yr}^{-1}\right)\end{array}$ & $\begin{array}{l}\text { TP load } \\
\text { attenuated } \\
\text { to the } \\
\text { nearby } \\
\text { stream } \\
\left(\text { mtons } \mathbf{y r}^{-1} \text { ) }\right.\end{array}$ & $\begin{array}{c}\text { TP load } \\
\text { attenuated to } \\
\text { the outlet } \\
\left(\text { mtons } \mathbf{y r}^{-1}\right)\end{array}$ \\
\hline \multicolumn{5}{|l|}{ Nonpoint Sources } \\
\hline Citrus & 1.3 & 0.9 & 1.3 & $1.2(1.0 \%)$ \\
\hline Improved pasture & 69.4 & 1.9 & 59.4 & $54.6(47.2 \%)$ \\
\hline Unimproved pasture & 1.3 & 0.7 & 1.2 & $1.1(1.0 \%)$ \\
\hline $\begin{array}{l}\text { Rangeland and } \\
\text { wooded pasture }\end{array}$ & 0.3 & 1.1 & 0.3 & $0.3(0.2 \%)$ \\
\hline Field crops & 10.4 & 5.9 & 8.5 & $8.0(6.9 \%)$ \\
\hline Ornamentals & 4.0 & 8.0 & 3.4 & $3.2(2.8 \%)$ \\
\hline Row crops & 0.5 & 2.4 & 0.5 & $0.4(0.4 \%)$ \\
\hline Sod & 5.3 & 4.1 & 4.6 & $4.1(3.6 \%)$ \\
\hline Sugarcane & 1.5 & 0.4 & 1.2 & $1.2(1.0 \%)$ \\
\hline Urban & 10.2 & 1.0 & 6.3 & $5.8(5.0 \%)$ \\
\hline Natural areas & 6.3 & 0.4 & 4.9 & $4.5(3.8 \%)$ \\
\hline Sub-total & 110.5 & 1.5 & 91.5 & $84.3(72.8 \%)$ \\
\hline \multicolumn{5}{|l|}{ Point Sources } \\
\hline CAFOs & 39.3 & 9.9 & 33.4 & $31.4(27.2 \%)$ \\
\hline Total & 149.8 & 1.9 & 124.9 & $115.7(100 \%)$ \\
\hline
\end{tabular}

CAFOs: Concentrated animal feeding operations.

Table 4-6. Total annual costs and corresponding potential cost savings for the commandand-control (CAC) and the least-cost abatement (LCA) approaches for achieving different TP load reduction targets in the Upper Kissimmee (UK) sub-watershed.

\begin{tabular}{|c|c|c|c|c|}
\hline $\begin{array}{c}\text { Baseline TP } \\
\text { load (mtons } \\
\left.\qquad \mathbf{y r}^{-1}\right)\end{array}$ & $\begin{array}{c}\text { TP load } \\
\text { reduction } \\
\text { target } \\
\left.\text { (mtons yr }{ }^{-1}\right)\end{array}$ & $\begin{array}{l}\text { Total CAC cost } \\
\left(\$ \text { million } \mathrm{yr}^{-1}\right)\end{array}$ & $\begin{array}{l}\text { Total LCA cost } \\
\left(\$ \text { million } \mathrm{yr}^{-1}\right)\end{array}$ & $\begin{array}{l}\text { Potential cost } \\
\text { savings } \\
\left(\$ \text { million } \mathrm{yr}^{-1}\right)\end{array}$ \\
\hline 78.7 & $32.3(41 \%)$ & $\$ 43.2$ & $\$ 8.9$ & $\$ 34.3(79 \%)$ \\
\hline 78.7 & 35.9 (46\%) & $\$ 45.6$ & $\$ 11.7$ & \$ 33.9 (74\%) \\
\hline 78.7 & 43.8 (56\%) & \$ 148.6 & $\$ 21.4$ & \$ $127.2(86 \%)$ \\
\hline 78.7 & 47.9 (61\%) & \$ 151.6 & $\$ 81.1$ & \$ $70.4(46 \%)$ \\
\hline 78.7 & $50.1(64 \%)$ & \$ 151.0 & $\$ 122.2$ & \$ 38.8 (24\%) \\
\hline 78.7 & 52.8 (67\%) & \$ 214.8 & \$ 154.9 & \$ 59.9 (28\%) \\
\hline 78.7 & $55.4(70 \%)$ & \$ 219.3 & \$ 216.5 & \$ 2.8 (1\%) \\
\hline 78.7 & $56.2(71 \%)$ & $\$ 233.5$ & $\$ 221.9$ & \$ $11.6(5 \%)$ \\
\hline
\end{tabular}


Table 4-7. Total annual costs and corresponding potential cost savings for the commandand-control (CAC) and the least-cost abatement (LCA) approaches for achieving different TP load reduction targets in the Taylor Creek/Nubbin Slough (TCNS) subwatershed.

\begin{tabular}{|c|c|c|c|c|}
\hline $\begin{array}{c}\text { Baseline TP } \\
\text { load (mtons } \\
\left.\qquad \mathrm{yr}^{-1}\right)\end{array}$ & $\begin{array}{c}\text { TP load } \\
\text { reduction } \\
\text { target } \\
\left(\text { mtons yr }^{-1}\right)\end{array}$ & $\begin{array}{l}\text { Total CAC cost } \\
\left(\$ \text { million } \mathbf{y r}^{-1}\right)\end{array}$ & $\begin{array}{l}\text { Total LCA cost } \\
\left(\$ \text { million } \mathbf{y r}^{-1}\right)\end{array}$ & $\begin{array}{l}\text { Potential cost } \\
\text { savings } \\
\left(\$ \text { million } \mathrm{yr}^{-1}\right)\end{array}$ \\
\hline 120.1 & $36.4(30 \%)$ & $\$ 6.9$ & $\$ 2.9$ & $\$ 4.0(58 \%)$ \\
\hline 120.1 & $38.8(32 \%)$ & $\$ 7.1$ & $\$ 3.4$ & \$ 3.7 (53\%) \\
\hline 120.1 & $48.6(41 \%)$ & $\$ 8.1$ & $\$ 5.0$ & \$ 3.1 (38\%) \\
\hline 120.1 & $52.2(43 \%)$ & $\$ 8.6$ & $\$ 6.1$ & \$ 2.5 (29\%) \\
\hline 120.1 & $68.0(57 \%)$ & $\$ 11.2$ & $\$ 10.1$ & \$ $0.6(5 \%)$ \\
\hline
\end{tabular}

Table 4-8. Number of credits available to sell and number of potential sellers and buyers for different TP load reduction targets in the Upper Kissimmee (UK) sub-watershed.

\begin{tabular}{cccc}
\hline $\begin{array}{c}\text { TP load } \\
\text { reduction } \\
\text { target (\%) }\end{array}$ & $\begin{array}{c}\text { No. of credits } \\
\text { available }\end{array}$ & $\begin{array}{c}\text { No. of potential } \\
\text { sellers }\end{array}$ & $\begin{array}{c}\text { No. of potential } \\
\text { buyers }\end{array}$ \\
\hline $41 \%$ & 7,785 & 26 & 15 \\
$46 \%$ & 6,339 & 23 & 20 \\
$56 \%$ & 9,694 & 31 & 2 \\
$61 \%$ & 6,400 & 27 & 1 \\
$64 \%$ & 3,270 & 18 & 6 \\
$67 \%$ & 3,003 & 15 & 7 \\
$70 \%$ & 577 & 7 & 12 \\
$71 \%$ & 709 & 4 & 18 \\
\hline
\end{tabular}

Table 4-9. Number of credits available to sell and number of potential sellers and buyers for different TP load reduction targets in the Taylor Creek/Nubbin Slough (TCNS) subwatershed.

\begin{tabular}{cccc}
\hline $\begin{array}{c}\text { TP load } \\
\text { reduction } \\
\text { target (\%) }\end{array}$ & $\begin{array}{c}\text { No. of credits } \\
\text { available }\end{array}$ & $\begin{array}{c}\text { No. of potential } \\
\text { sellers }\end{array}$ & $\begin{array}{c}\text { No. of potential } \\
\text { buyers }\end{array}$ \\
\hline $30 \%$ & 20,318 & 31 & 8 \\
$32 \%$ & 20,897 & 20 & 13 \\
$41 \%$ & 20,893 & 23 & 14 \\
$43 \%$ & 20,092 & 19 & 14 \\
$57 \%$ & 2,716 & 16 & 11 \\
\hline
\end{tabular}


Table 4-10. Net cost savings of the WQTP for the Upper Kissimmee (UK) and Taylor Creek/ Nubbin Slough (TCNS) sub-watersheds using the selected TP reduction targets.

\begin{tabular}{|c|c|c|c|}
\hline & UK & TCNS & Units \\
\hline Baseline TP load & 78.7 & 120.0 & mtons $\mathrm{yr}^{-1}$ \\
\hline TP load reduction target & 46 & 32 & $\%$ \\
\hline Load after BMPs and technologies are adopted & 42.8 & 81.3 & mtons $\mathrm{yr}^{-1}$ \\
\hline Credits traded & 4,601 & 10,495 & kg reduced \\
\hline Credit price & $\$ 673$ & $\$ 130$ & $\$ \mathrm{~kg}^{-1}$ reduced \\
\hline Cost incurred by sellers under the CAC approach & $\$ 0.2$ & $\$ 0.2$ & \$ million $\mathrm{yr}^{-1}$ \\
\hline Cost incurred by sellers under the LCA approach & $\$ 2.3$ & $\$ 1.2$ & \$ million $\mathrm{yr}^{-1}$ \\
\hline Cost incurred by buyers under the CAC approach & $\$ 40.2$ & $\$ 4.5$ & \$ million $\mathrm{yr}^{-1}$ \\
\hline Cost incurred by buyers under the LCA approach & $\$ 2.9$ & $\$ 0.2$ & \$ million $\mathrm{yr}^{-1}$ \\
\hline Cost of credits traded & $\$ 3.1$ & $\$ 1.4$ & \$ million $\mathrm{yr}^{-1}$ \\
\hline Cost of transaction ( $10 \%$ of credits traded) & $\$ 0.3$ & $\$ 0.1$ & \$ million $\mathrm{yr}^{-1}$ \\
\hline Savings for sellers & $\$ 1.0$ & $\$ 0.3$ & $\$$ million $\mathrm{yr}^{-1}$ \\
\hline Savings for buyers & $\$ 33.9$ & $\$ 2.8$ & $\$$ million $\mathrm{yr}^{-1}$ \\
\hline \multirow{2}{*}{ Net cost savings } & $\$ 34.9$ & $\$ 3.2$ & \$ million $y^{-1}$ \\
\hline & 76 & 45 & $\%$ \\
\hline
\end{tabular}

TP: Total phosphorus; CAC: command-and-control; LCA: least-cost abatement. 


\subsection{Figures}

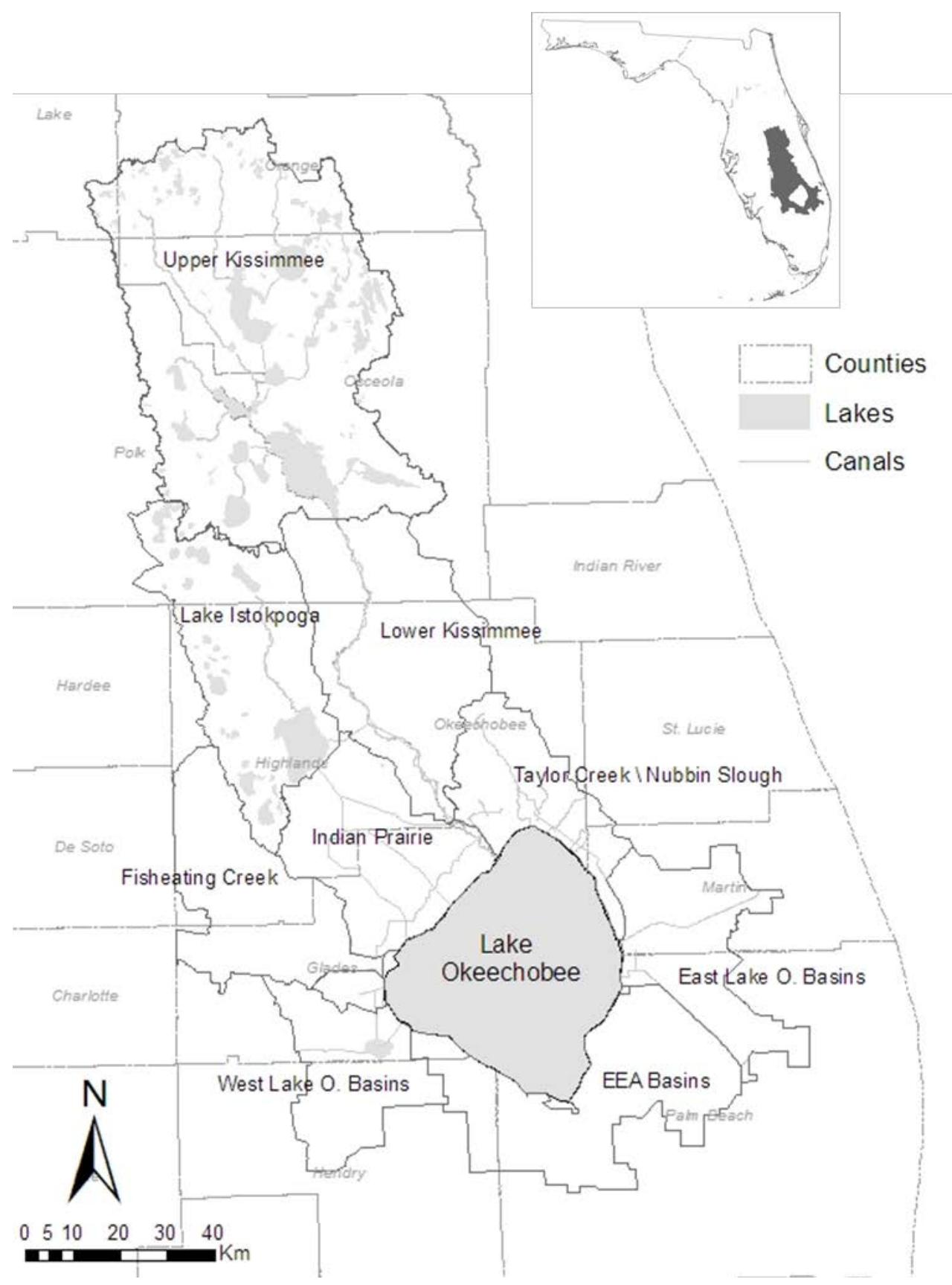

Figure 4-1. Lake Okeechobee watershed (LOW) detailing the sub-watershed boundaries and the major hydrologic components. 

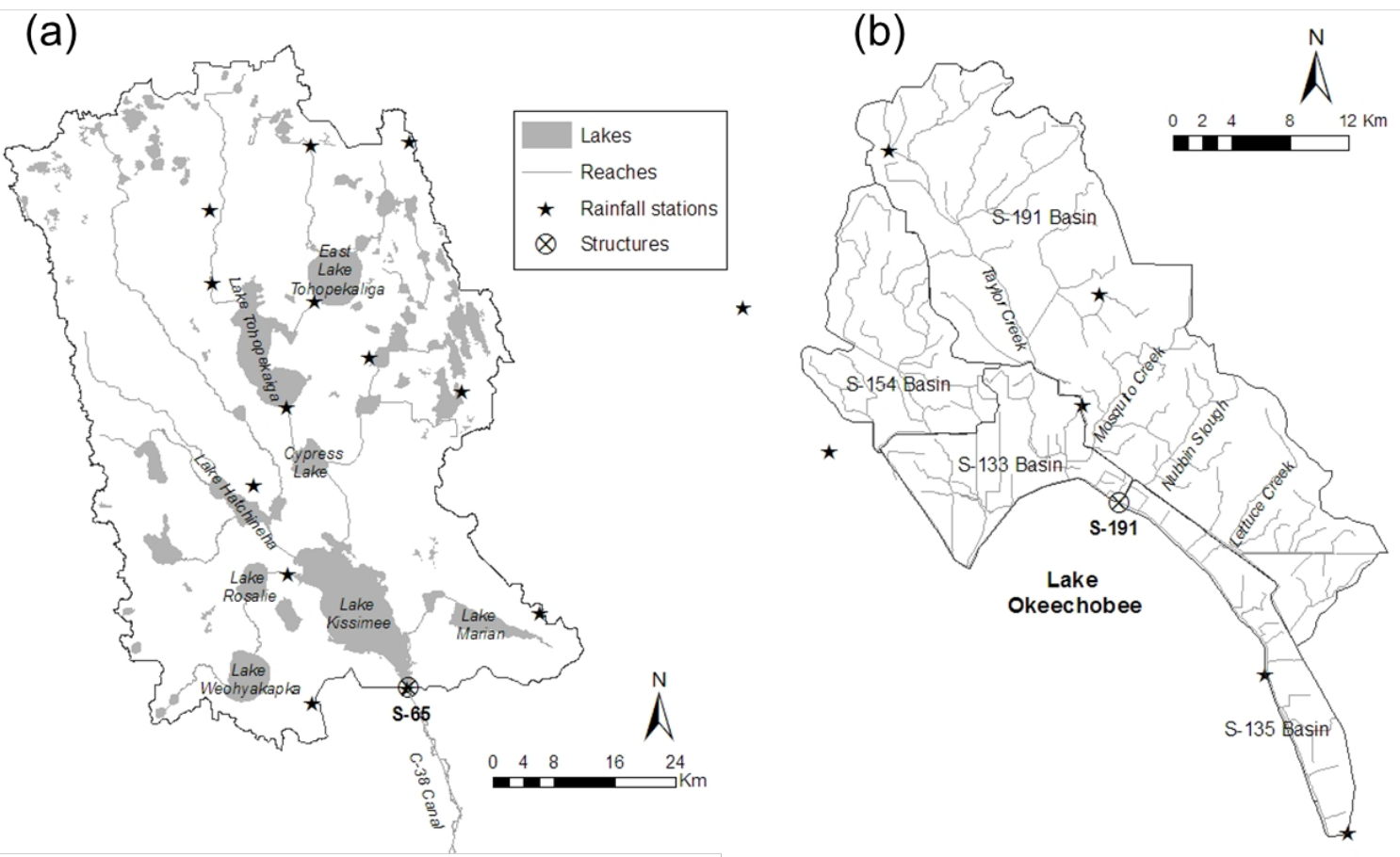

Figure 4-2. Study areas (a) Upper Kissimmee (UK) and (b) Taylor Creek/Nubbin Slough (TCNS) illustrating the major hydrologic components and the rainfall stations.
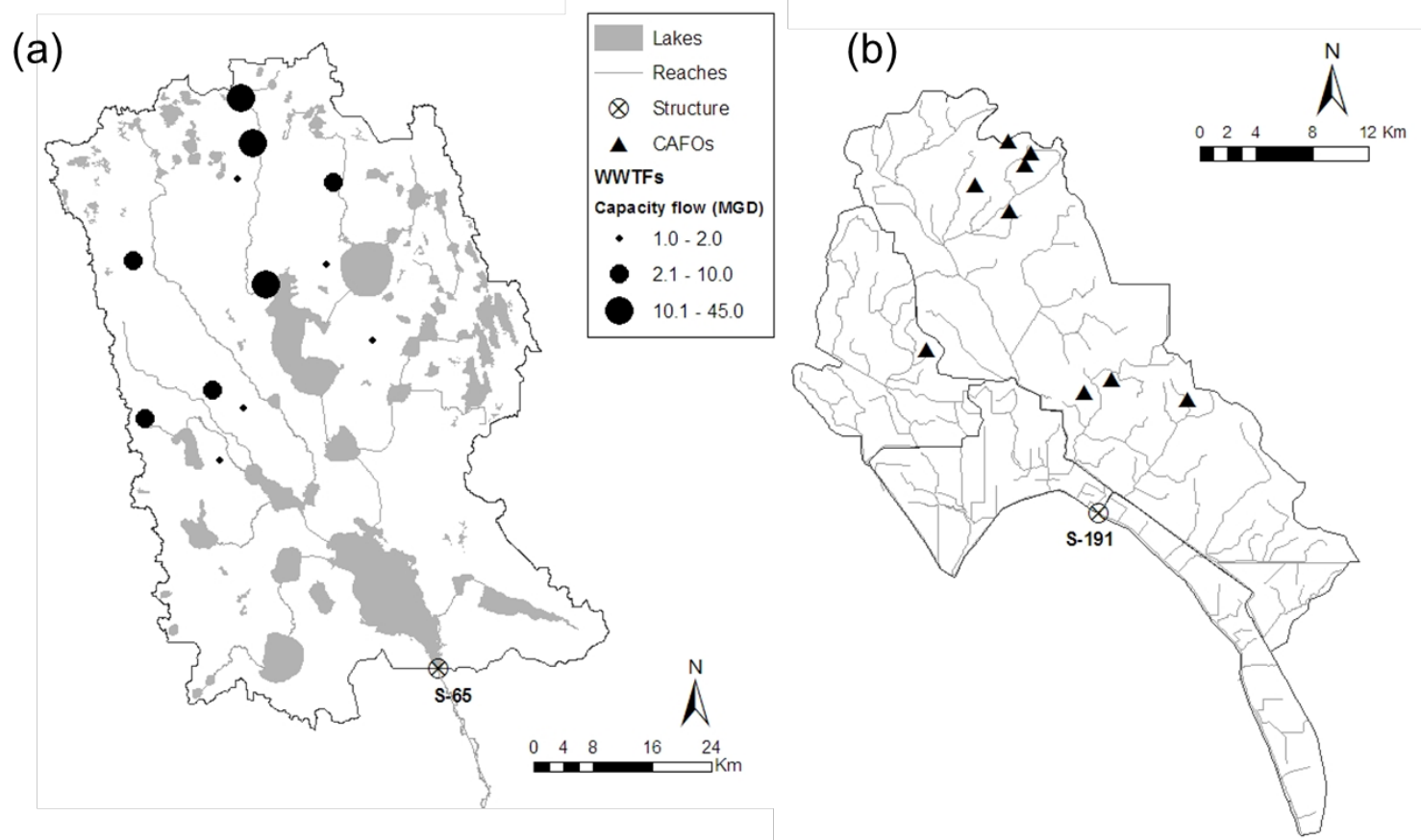

Figure 4-3. Location of selected point sources in the (a) Upper Kissimmee (UK) and (b) Taylor Creek/Nubbin Slough (TCNS) sub-watersheds. 


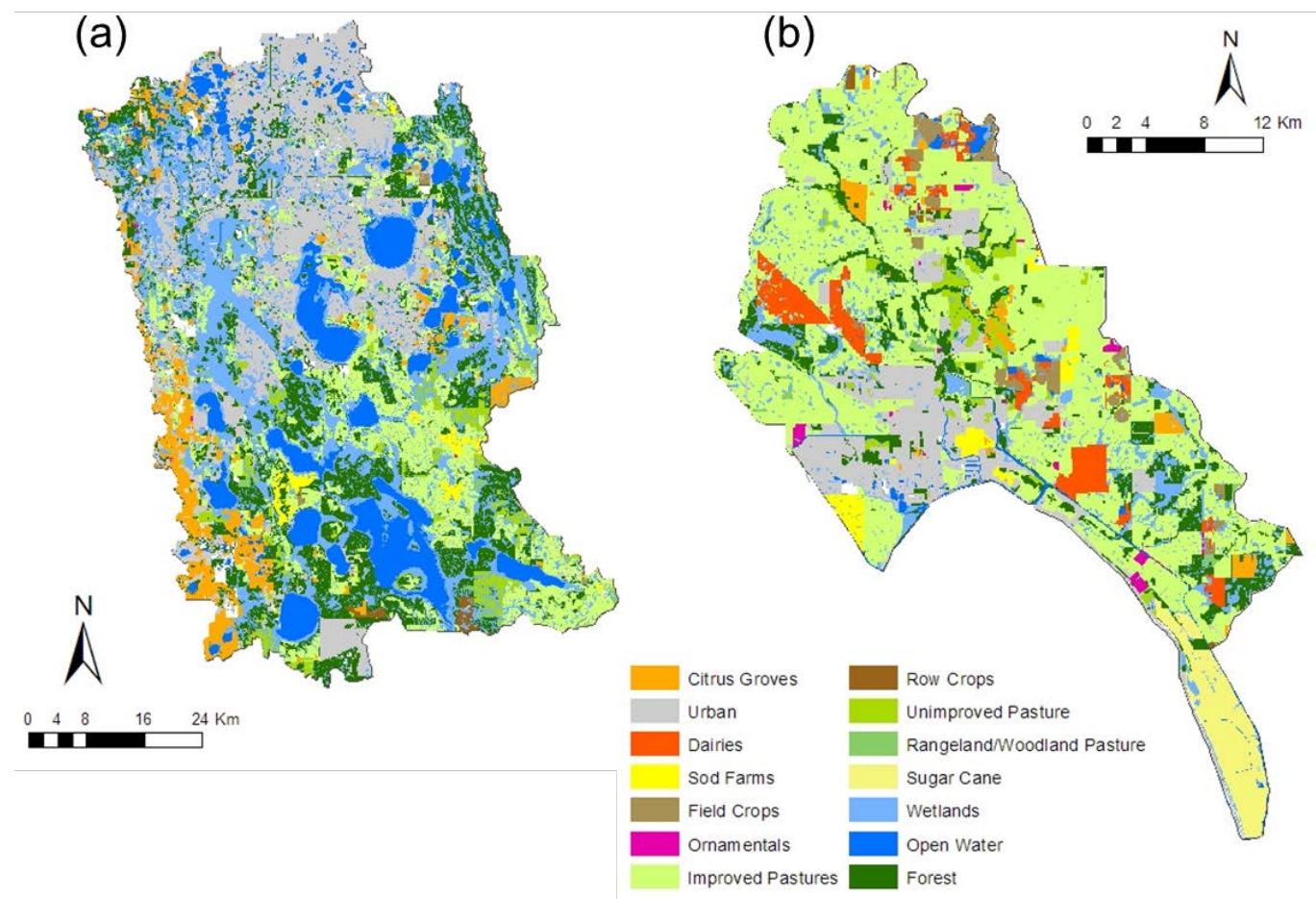

Figure 4-4. Land use distribution in the (a) Upper Kissimmee (UK) and (b) Taylor Creek/Nubbin Slough (TCNS) sub-watersheds.
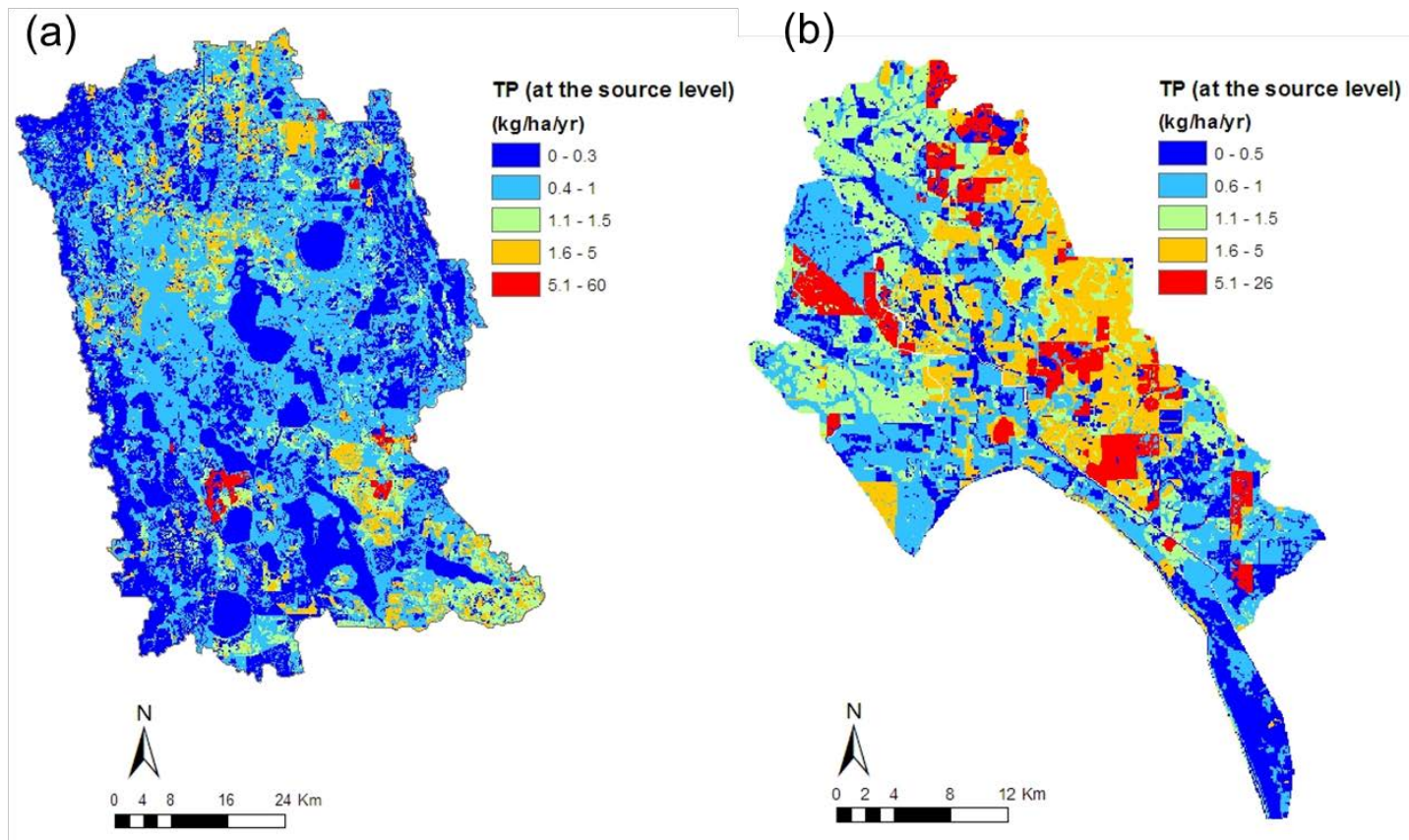

Figure 4-5. Total Phosphorus (TP) loading spatial distribution ( $\left.\mathrm{kg} \mathrm{ha}^{-1} \mathrm{yr}^{-1}\right)$ at the source level in the (a) Upper Kissimmee (UK) and (b) Taylor Creek/Nubbin Slough (TCNS) sub-watersheds. 
(a)

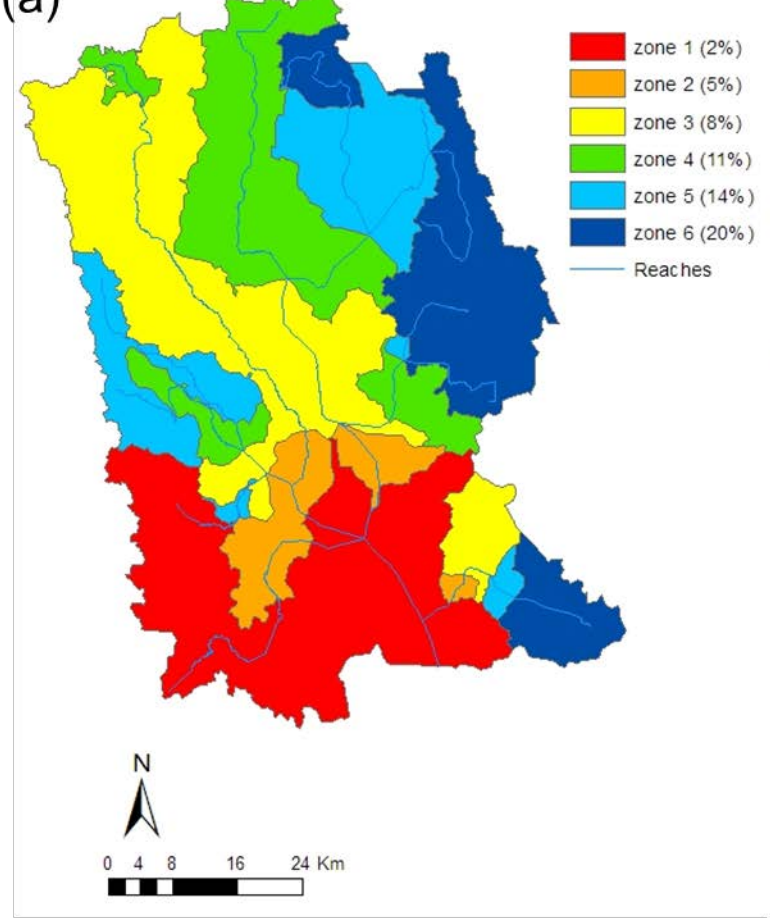

(b)

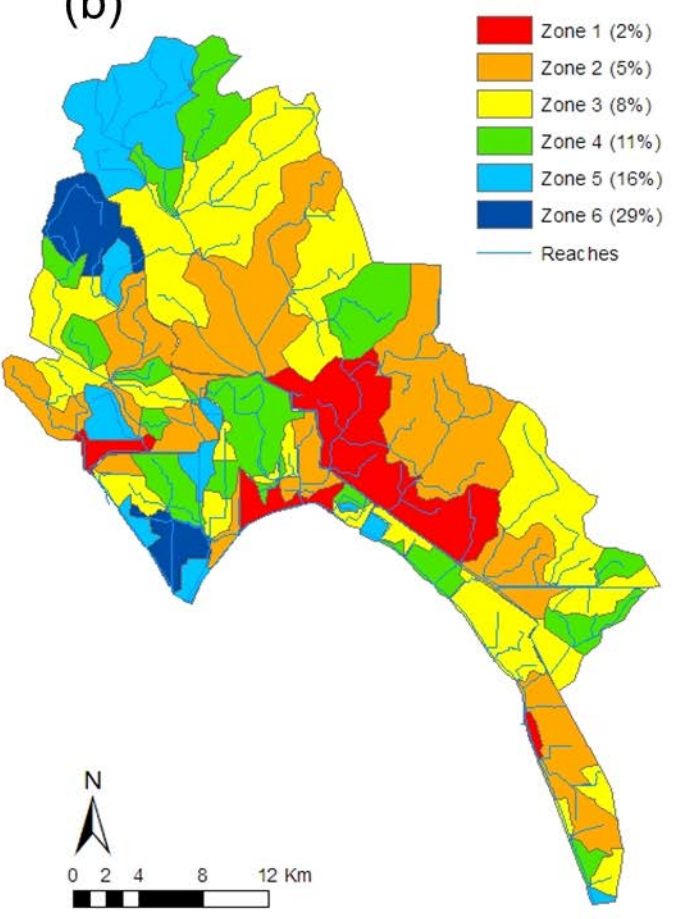

Figure 4-6. Zone classification of the phosphorus attenuation factors in the (a) Upper Kissimmee (UK) and (b) Taylor Creek/Nubbin Slough (TCNS) sub-watersheds. 
(a)

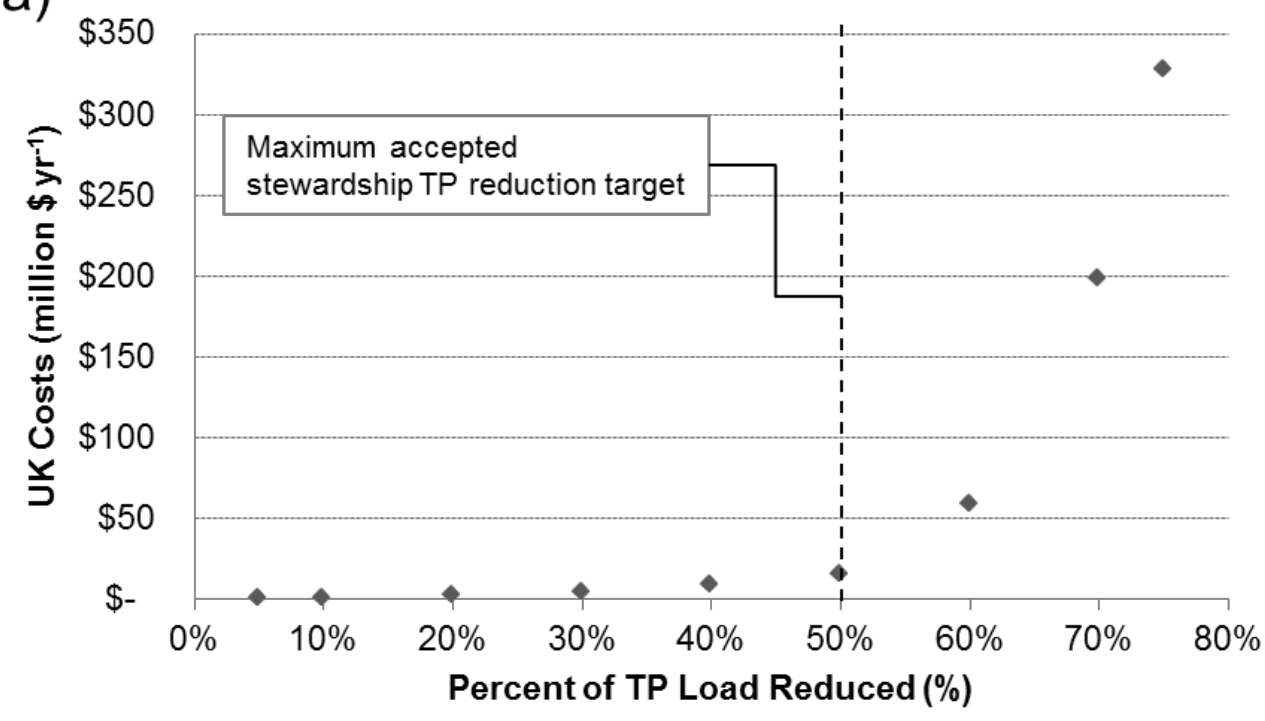

(b)

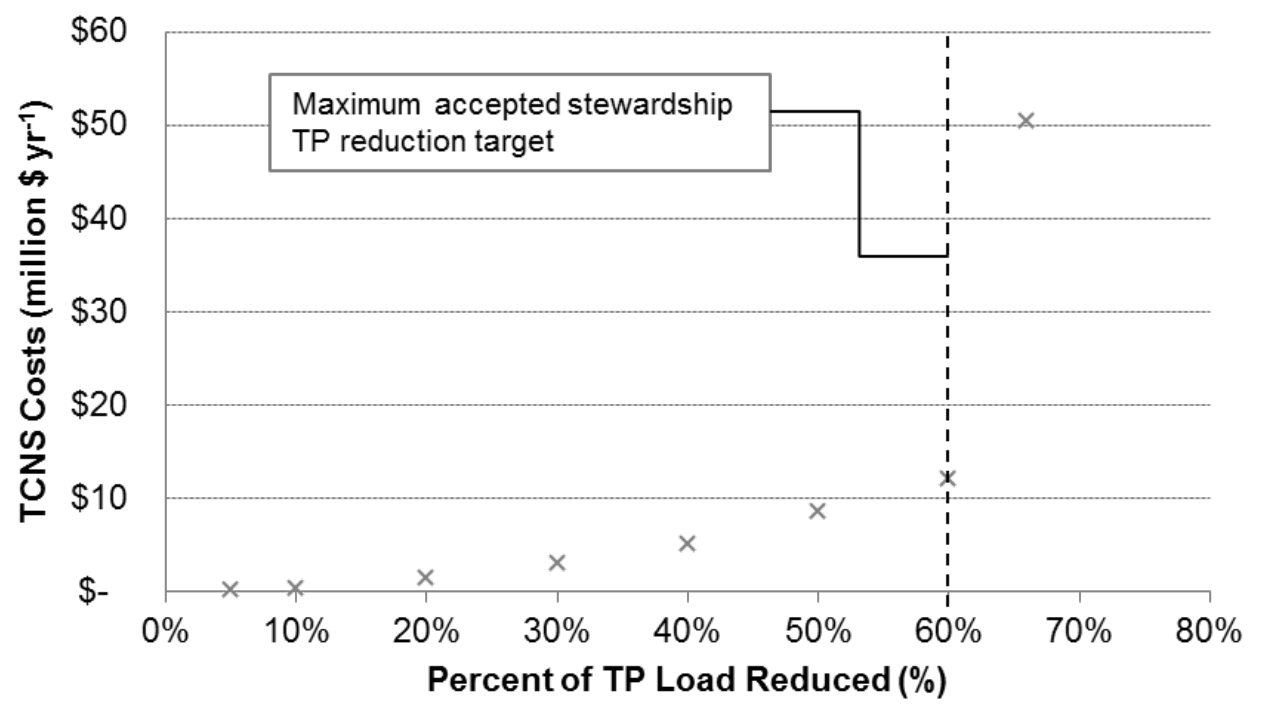

Figure 4-7. Total annual costs ( $\$$ million $\mathrm{yr}^{-1}$ ) for achieving different TP load reduction targets in the (a) Upper Kissimmee (UK) and (b) Taylor Creek/Nubbin Slough (TCNS) sub-watersheds. 
(a)

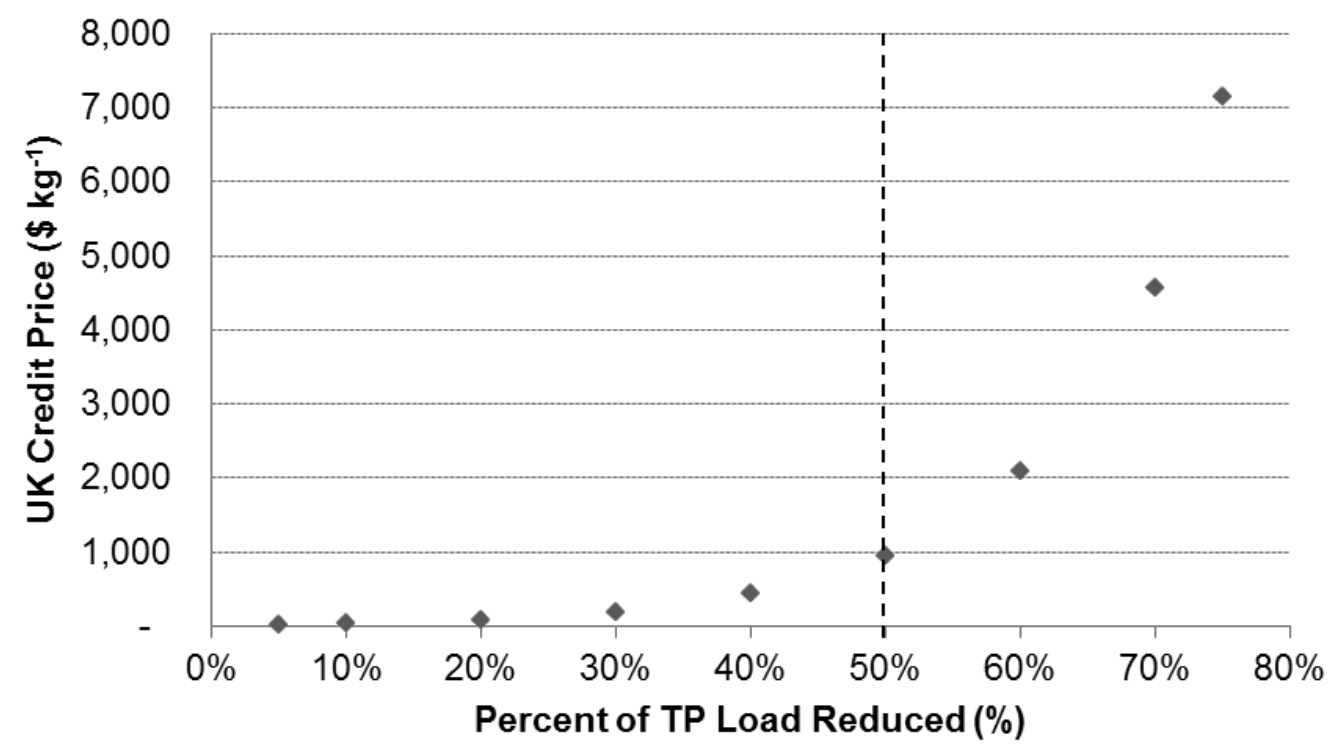

(b)

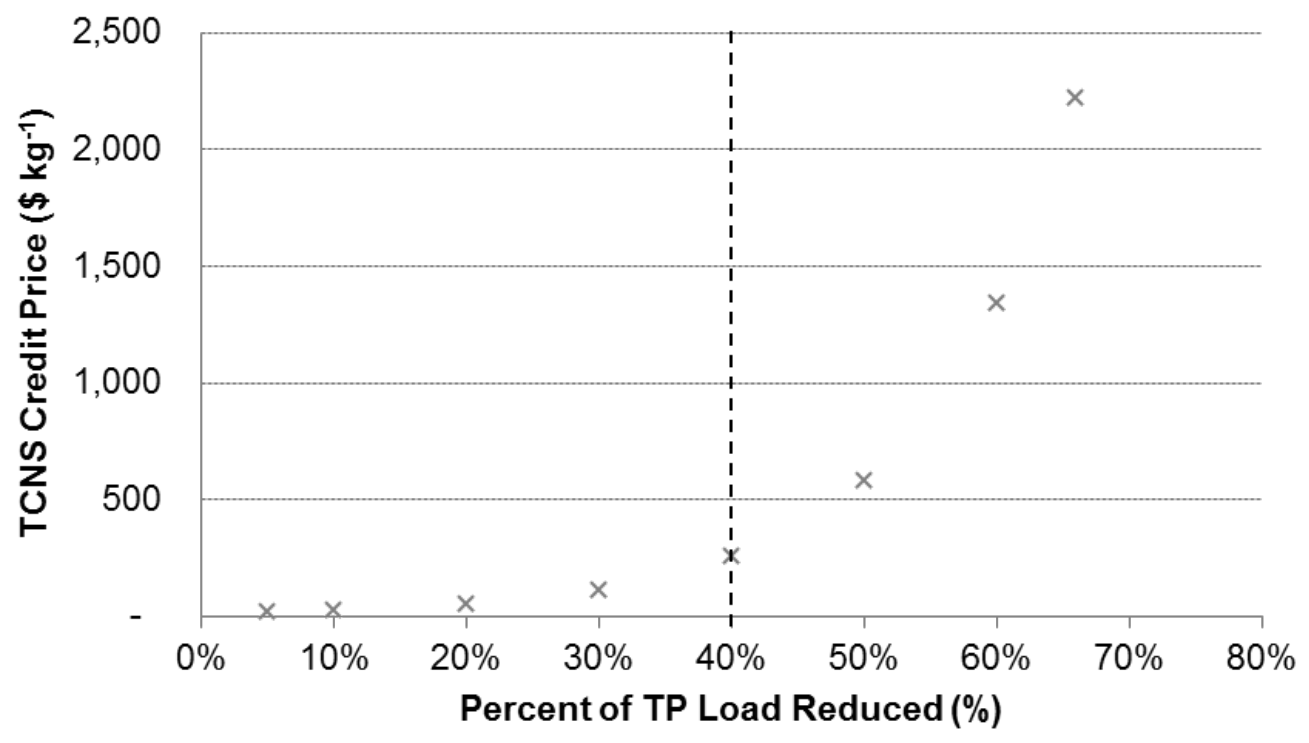

Figure 4-8. Credit prices ( $\$ \mathrm{~kg}^{-1}$ of TP reduced) for achieving different TP load reduction targets in the (a) Upper Kissimmee (UK) and (b) Taylor Creek/Nubbin Slough (TCNS) sub-watersheds. 

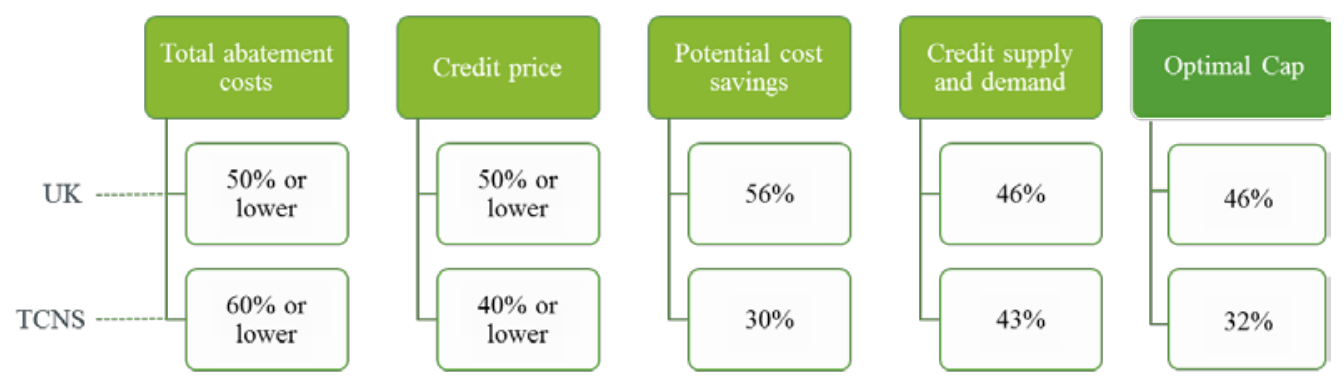

Figure 4-9. Summary of the four factors influencing the selection of the cap level for the Upper Kissimmee (UK) and Taylor Creek/Nubbin Slough (TCNS) sub-watersheds.

(a) Command-and-control (CAC)
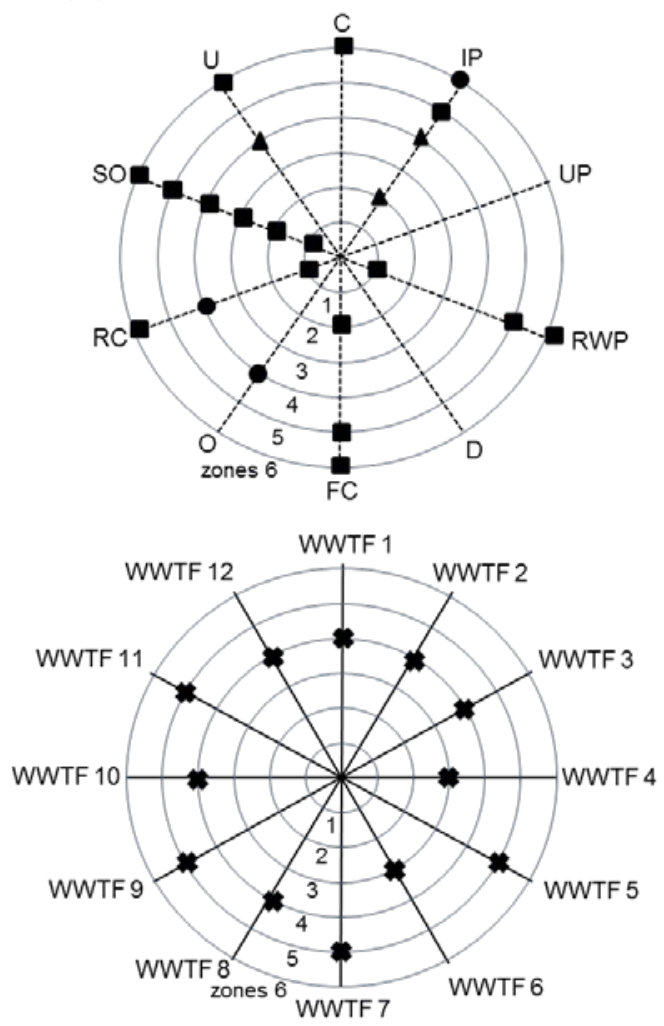

(b) Least-cost abatement (LCA)
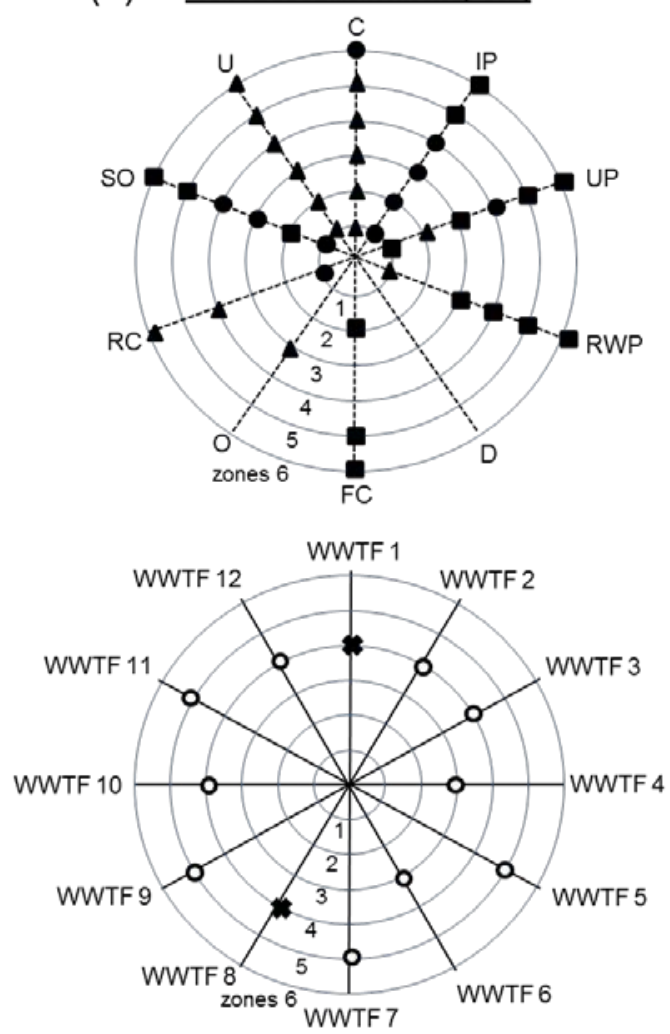

$\triangle$ BMPI • BMP II — BMP III O AWTI * AWT II

Figure 4-10. Best management practices (BMP) and advanced wastewater treatment (AWT) technologies selected in the Upper Kissimmee (UK) sub-watershed under the (a) CAC and (b) LCA approaches for meeting a preset 46\% TP load reduction target. C stands for citrus, IP for improved pastures, UP for unimproved pastures, RWP for rangeland and wooded pastures, $\mathrm{D}$ for dairies, FC for field crops, $\mathrm{O}$ for ornamentals, $\mathrm{RC}$ for row crops, SO for sod, U for urban, and WWTF for wastewater treatment facilities. 
(a) Command-and-control (CAC)

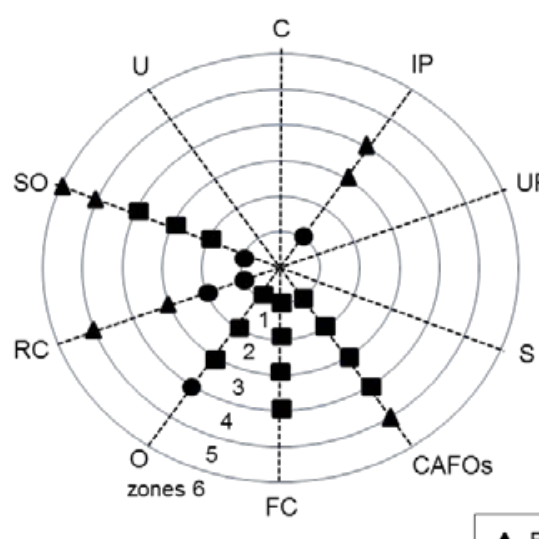

(b) Least-cost abatement (LCA)

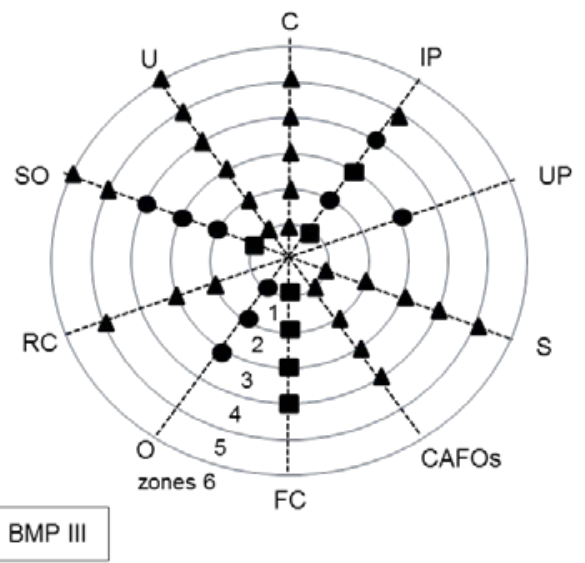

Figure 4-11. Best management practices (BMP) selected in the Taylor Creek/Nubbin Slough (TCNS) sub-watershed under the (a) CAC and (b) LCA approaches for meeting a preset 32\% TP load reduction target. C stands for citrus, IP for improved pastures, UP for unimproved pastures, $\mathrm{S}$ for sugarcane, CAFOs for concentrated animal food operations, FC for field crops, O for ornamentals, RC for row crops, SO for sod, and U for urban. 


\section{CHAPTER 5}

\section{SUMMARY, CONCLUSIONS, AND RECOMMENDATIONS}

\subsection{Summary and Conclusions}

For the past decades, incentive-based programs have been an area of active development to solve environmental problems. Incentive-based policies relie on market incentives to both, reduce pollution and minimize abatement costs. In order to better understand the prospects of this policy in the water quality arena, this dissertation examined the advantages and challenges that have arisen from the nationally and internationally implemented programs so far. As discussed in Chapter 2, costeffectiveness, decision making flexibility, involvement of non-regulated pollution sources, and technological innovation for pollution abatement were highlighted as major benefits promoting the development and implementation of water quality trading programs. Some of these theoretical advantages were observed in the case studies illustrated in this chapter. However, not a single policy comes without its drawbacks. The investigated case studies faced significant challenges from the policy design through the implementation phase. The major challenges discussed were the creation of localized areas with high pollution levels (known as "pollution hotspots”), uncertainties related to nonpoint source emissions, and the high transaction costs associated with research, negotiations, monitoring, and enforcement. Key elements to consider when designing and implementing a water quality trading program were pollutant suitability, abatement costs differentials among pollution sources, feasible market structures, and stakeholder's willingness to participate. Furthermore, the meta-analysis conducted using several water 
quality trading case studies revealed that minimization of nonpoint uncertainty, policy drivers, and social embeddedness were the most significant variables influencing the success of a trading program. The integration of those variables and the introduction of innovative thinking to overcome regulatory, technical, and economic challenges are of significant importance for the implementation of a viable and sustainable trading program.

A comprehensive modeling framework, integrating a hydrologic-water quality model with an economic model, was developed in Chapter 3 to assess and compare the costeffectiveness of two environmental policy strategies to reduce phosphorus loadings to Lake Okeechobee. In particular, I explored the benefits of implementing a water quality trading program in an agricultural watershed (S-191 sub-basin) in order to achieve a specific total phosphorus load reduction. Using the hydrologic-water quality model, water flows and phosphorus loads generated on-site (at the source level) and attenuated to the nearby stream were simulated. An additional in-stream attenuation algorithm was developed to account for further phosphorus loads assimilation from the stream network to the outlet of the sub-basin. Using the economic model, the least-cost combination of Best Management Practices (BMPs) and technologies was identified in order to achieve several phosphorus reduction targets. A cost-effective cap of 30\% total phosphorus reduction was selected for this sub-basin to develop a trading scenario and assess its benefits when compared to a command-and-control approach. Results of this analysis identified dairies, sod farms, and ornamentals land uses as potential credit buyers, whereas improved pastures, citrus, and urban areas were found as potential credit sellers. Furthermore, the estimated potential cost savings of the water quality trading scenario in 
the S-191 sub-basin versus a command-and-control approach were 27\% (\$ 1.3 million per year) based on a credit price of \$ 179 per kg of phosphorus reduced.

Motivated by the cost savings that could be generated from trading in an agricultural sub-basin of the Lake Okeechobee watershed, I explored the application of the modeling framework, developed in Chapter 3, in two larger sub-watersheds with different land use and hydrologic conditions. The two sub-watersheds selected, the Upper Kissimmee (UK) and Taylor Creek/ Nubbin Slough (TCNS), have been identified as major sources of total phosphorus loadings to the lake, representing priority areas for the implementation of water quality improving efforts. While evaluating and comparing the environmental and economic feasibility of a water quality trading program, the effect of different caps on the market potential was assessed in the two studied areas. Four factors influencing the selection of the cap were analyzed: the least-cost abatement solutions, credit prices, potential cost savings, and credit supply and demand. Hypothetical trading scenarios were also developed, using the optimal caps selected for the two sub-watersheds, to assess the economic advantages of a water quality trading program over a command-andcontrol approach in order to improve LO's water quality. In both sub-watersheds, a phosphorus credit trading program was less expensive than the conventional commandand-control approach. While attaining cost-effectiveness, keeping optimal credit prices, and fostering market competition, phosphorus reduction targets of $46 \%$ and $32 \%$ were selected as the most appropriate caps in the UK and TCNS sub-watersheds, respectively. Hypothetical trading scenarios identified wastewater treatment facilities (WWTFs) and urban areas in the UK, and concentrated animal feeding operations (CAFOs) in the TCNS sub-watershed, as potential credit buyers. Improved pastures were identified as the major 
credit sellers in both sub-watersheds. The estimated net cost savings resulting from implementing a phosphorus trading program in the UK and TCNS sub-watersheds were 76\% (\$ 34.9 million per year) and 45\% (\$3.2 million per year), respectively.

While the results of this dissertation are promising, it is important to note that water quality trading is not the only solution to improve Lake Okeechobee's health, but rather an additional tool to other phosphorus load reduction projects implemented in the watershed. The realization of the environmental and economic benefits of this marketbased alternative is also contingent on other important factors, such as the market structure, the specific program rules, the risk perception, and the education and outreach to develop trusted relationships among regulatory agencies, the public sector, and other stakeholders. Nevertheless, this research provided the foundation for stakeholders to better understand whether water quality trading has the potential to work in the Lake Okeechobee watershed and to facilitate the development of a pilot program. In addition, this dissertation offered some insights on the potential economic opportunities that pollution sources would have by participating in the trading program. Although this research focused on the Lake Okeechobee watershed, it also provides a base framework to assess the feasibility of future water quality trading programs in other watersheds.

\subsection{Recommendations and Future Work}

The results indicate that there is an important potential for a phosphorus trading program to generate cost savings and water quality benefits in Lake Okeechobee. Therefore, more efforts should be dedicated to this matter. The following 
recommendations, directed to future trading program managers, could help enhance the potential benefits of a trading program implemented in the watershed:

- Adopting a monitoring plan and increasing field-site inspections in the watershed to verify the modeling results of nonpoint source loadings. Monitoring and verification of load reductions from nonpoint sources and environmental performance of BMPs should be conducted whenever possible. Regulatory agencies responsibility should be shifted from imposing technologies and management practices to requiring monitoring and measurement of the discharged phosphorus loads. This would reduce the uncertainty about the magnitude of water quality improvement, not only for a trading program, but for any program involving nonpoint sources.

- Developing a market structure, such as clearinghouses or third-party aggregators to reduce transaction costs by gathering information and bringing trading partners together. In addition, the market structure could be enhanced by creating a standardized market platform that can assist potential trading sources to either estimate the amount of credits generated by adopting different management practices, or to quantify the amount of credits needed to purchase, based on location and trading ratios.

- Establishing an outreach program to educate stakeholders on the environmental and economic opportunities trading might offer, and on how potential trading sources could participate. This would strengthen the relationship and communication between regulators and trading participants, while encouraging the willingness to participate.

- Conducting an assessment of the cost-effectiveness and environmental benefits of a water quality trading program in all nine sub-watersheds discharging into Lake 
Okeechobee. Extending the geographic scope would allow the participation of a larger number of sellers and buyers and a wider range of abatement cost differentials that trading systems are designed to exploit.

- Developing a regulatory framework supporting a water quality trading program to be implemented as part of the Lake Okeechobee Basin Management Action Plan (BMAP). Water quality trading rules, protocols to quantify credits and phosphorus loads, liabilities in the event of failure to generate the expected credits, and eligibility for participation could be incorporated in the revision of the plan, offering an additional tool to achieve phosphorus load reductions within the watershed. 


\section{APPENDIX}

\section{CALIBRATION AND VALIDATION OF THE WATERSHED ASSESSMENT MODEL}

This section provides visual comparisons between daily observed (blue) and simulated (red) cumulative flows, total phosphorus (TP) concentration, and cumulative TP loadings at each of the outlet structures of the calibrated areas. A summary of the goodness-of-fit (GOF) statistical measures used for the calibration and validation processes of the Watershed Assessment Model (WAM) is also provided. The calibration and validation was performed in the Upper Kissimmee (UK) sub-watershed and in three of the four basins within the Taylor Creek/ Nubbin Slough sub-watershed (S-154, S-133, and S135). The calibration and validation of the S-191 basin is presented in SWET (2011b). The calibration parameters for the in-stream attenuation analysis are also reported in this Appendix. 
(a)

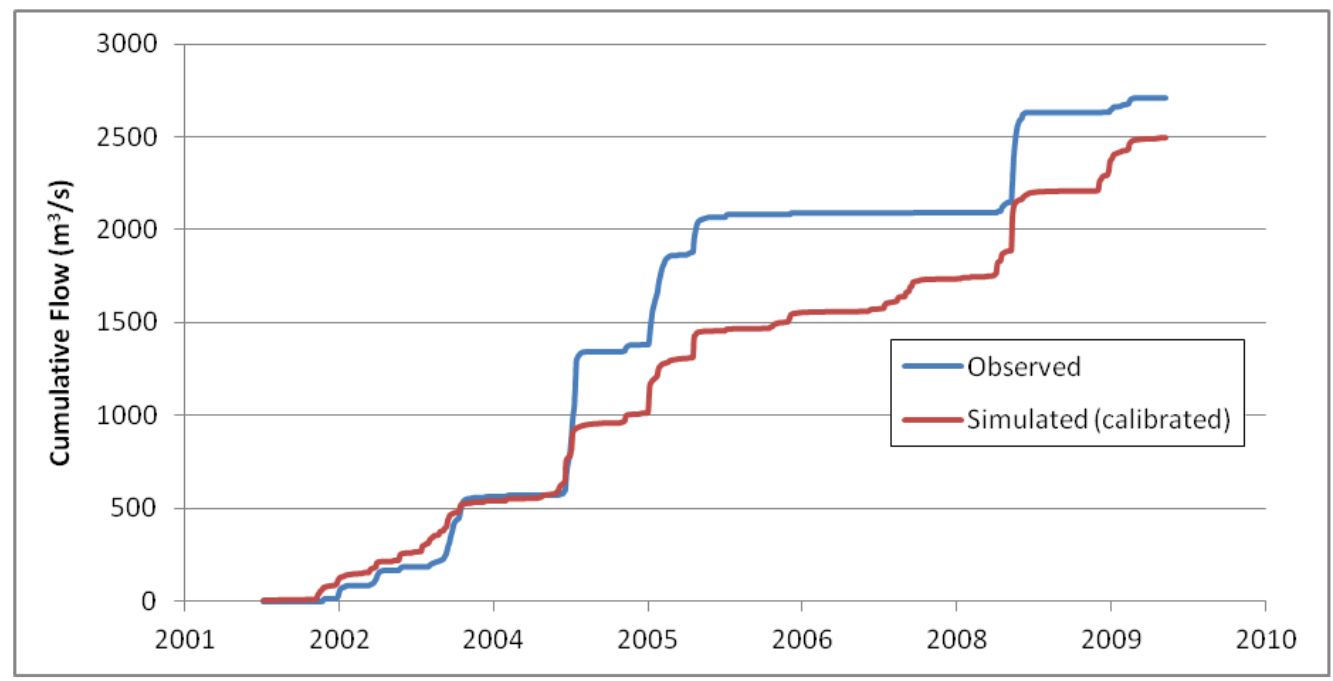

(b)

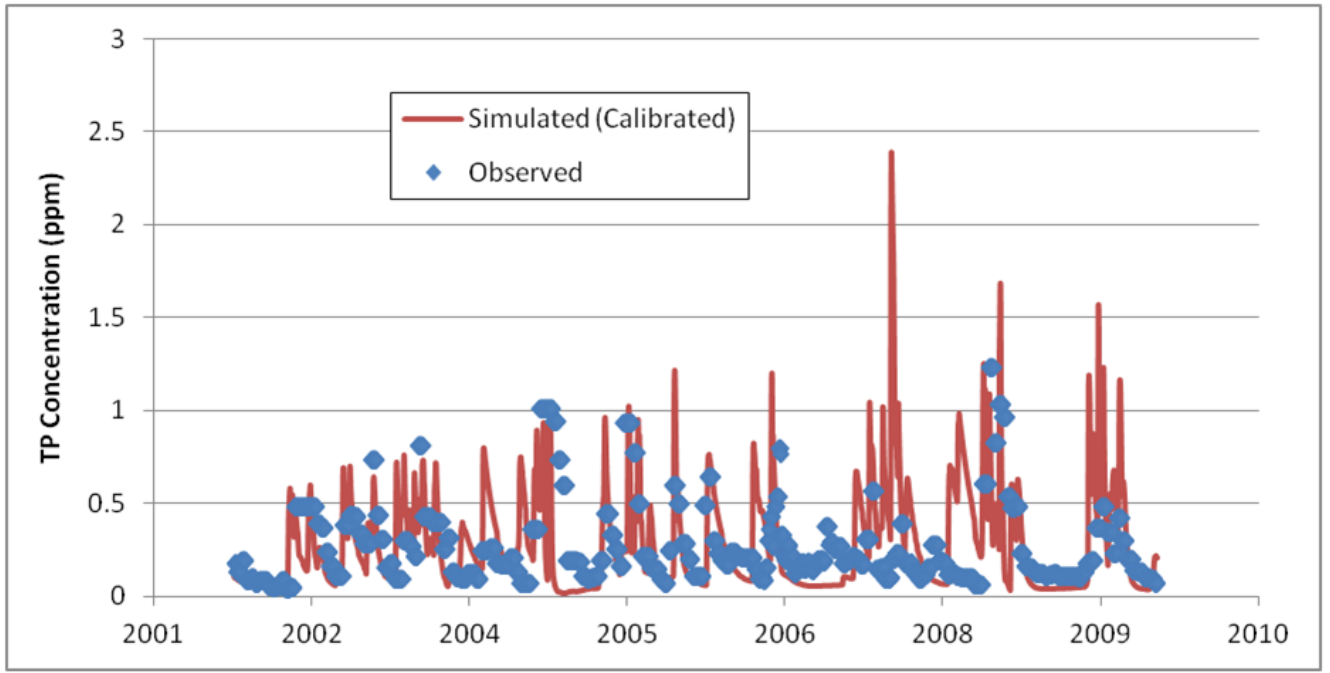

(c)

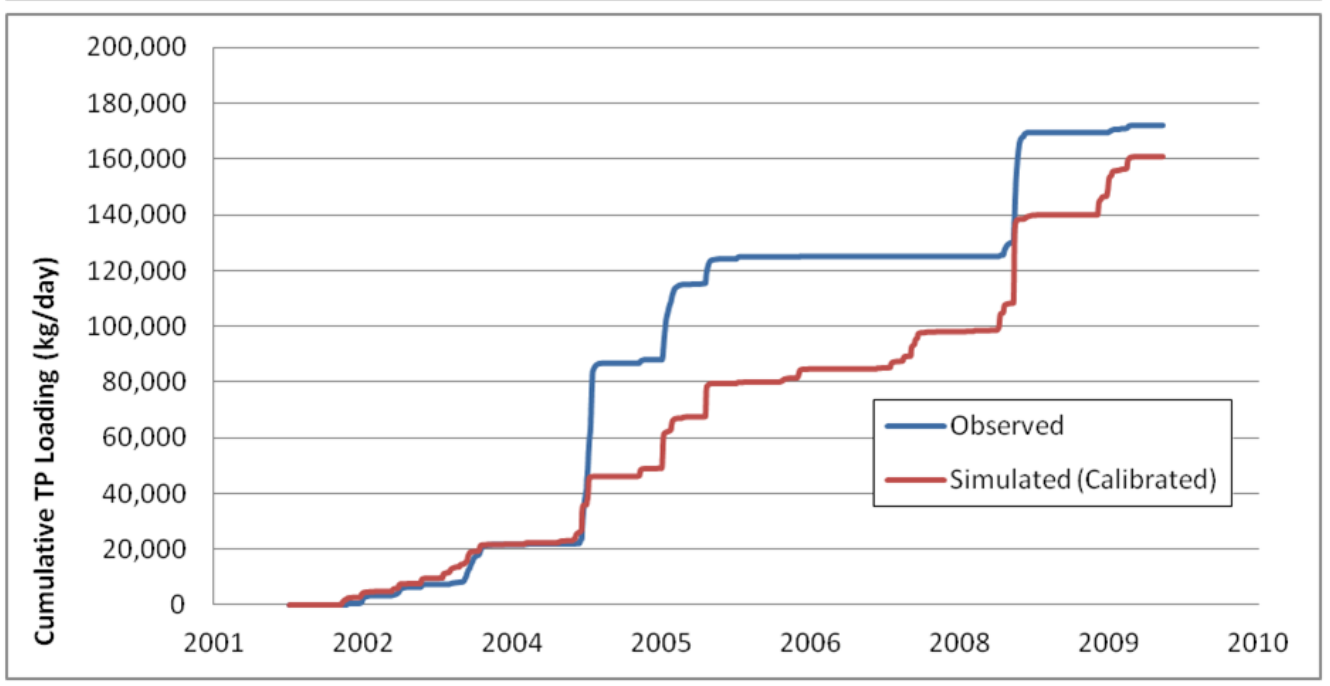

Figure A-1. Calibration results for daily (a) cumulative flow, (b) Total Phosphorus (TP) concentration, and (c) cumulative TP loading at the S-154 structure. 
(a)

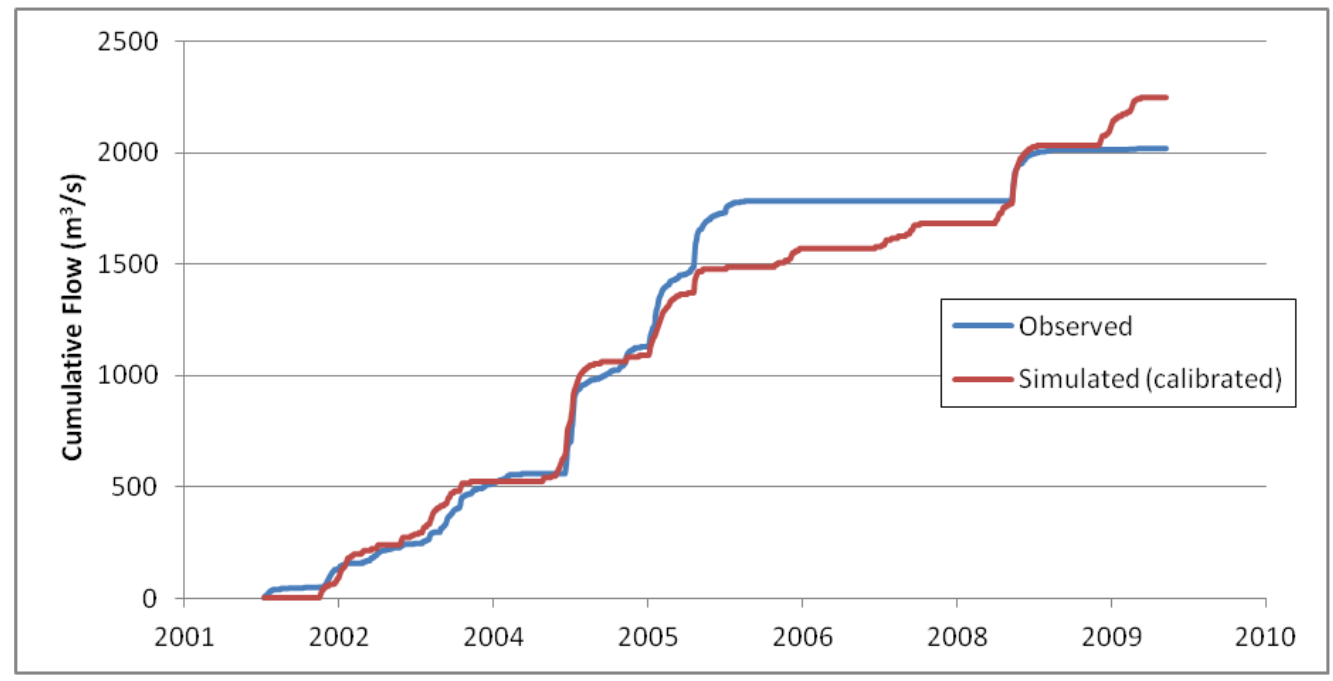

(b)

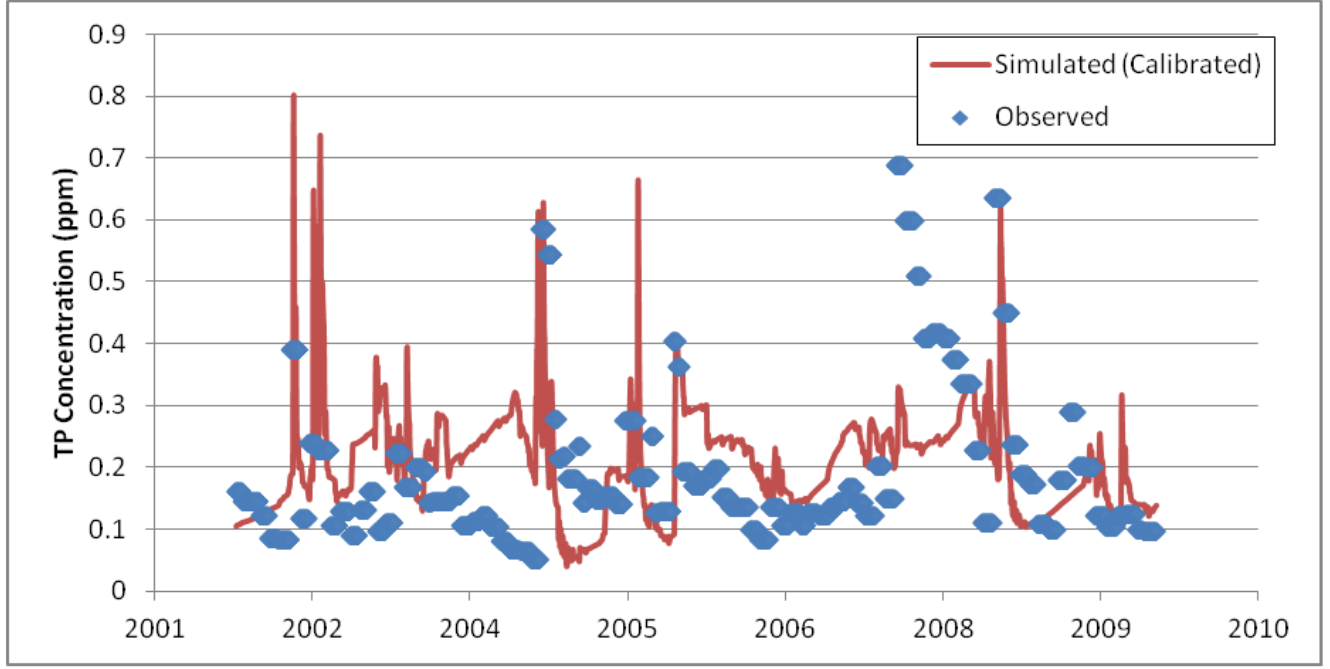

(c)

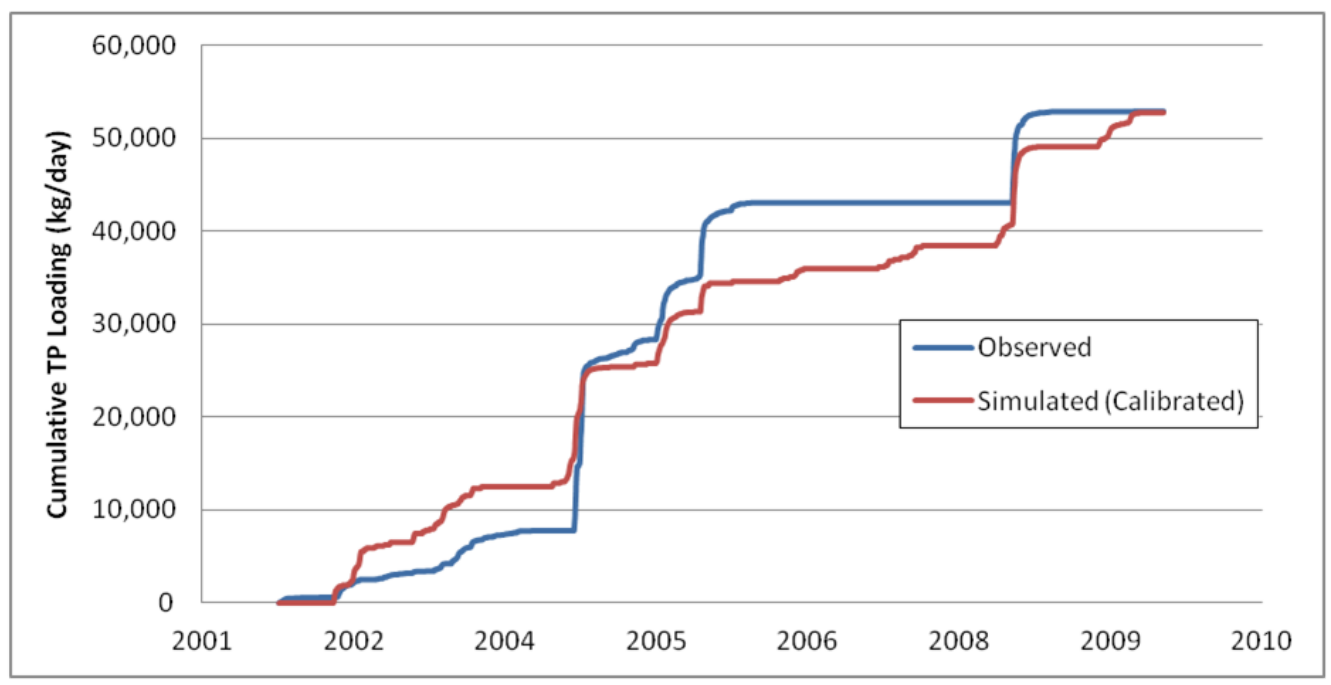

Figure A-2. Calibration results for daily (a) cumulative flow, (b) Total Phosphorus (TP) concentration, and (c) cumulative TP loading at the S-133 structure. 
(a)

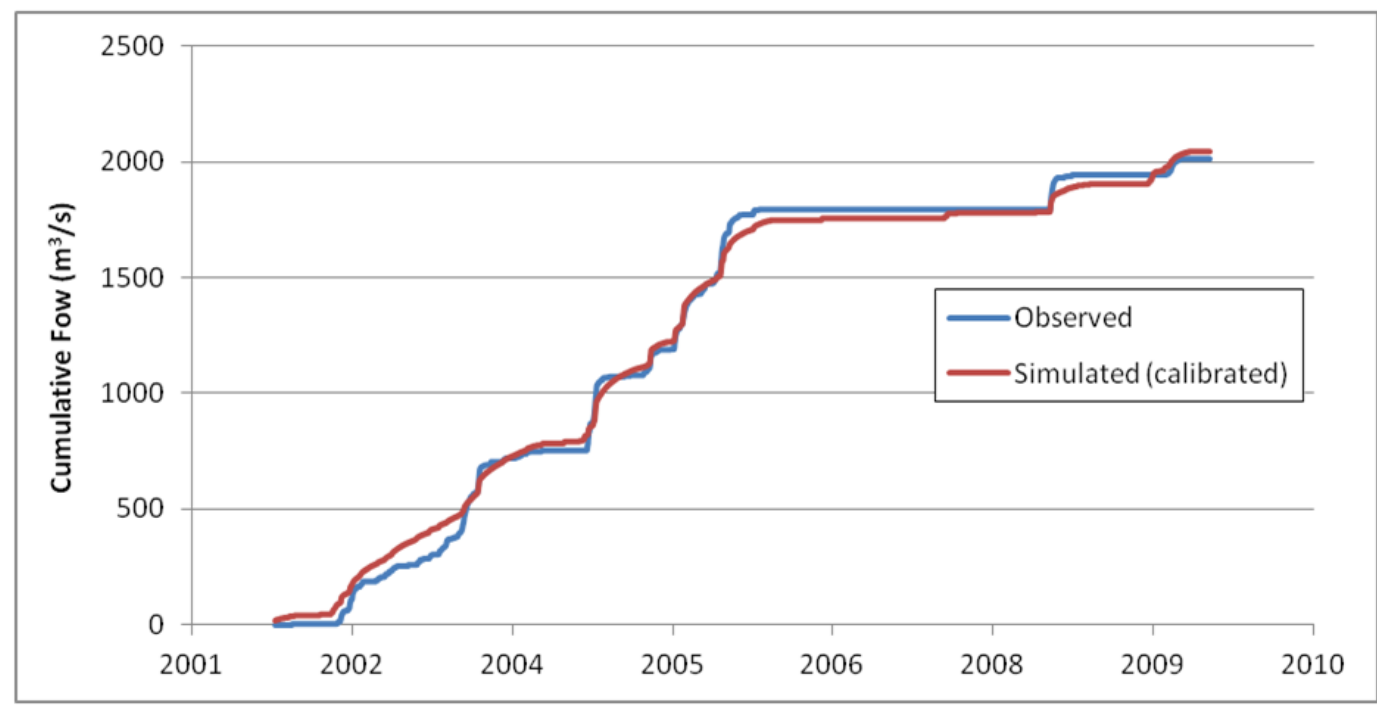

(b)

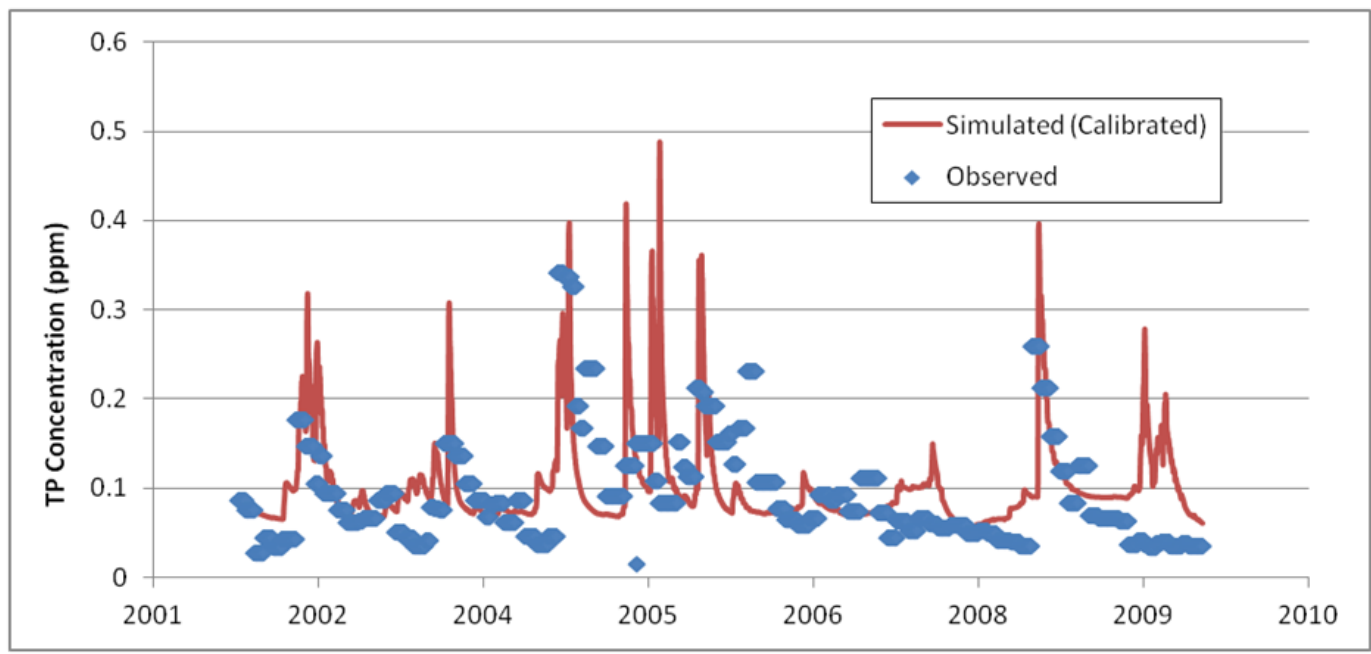

(c)

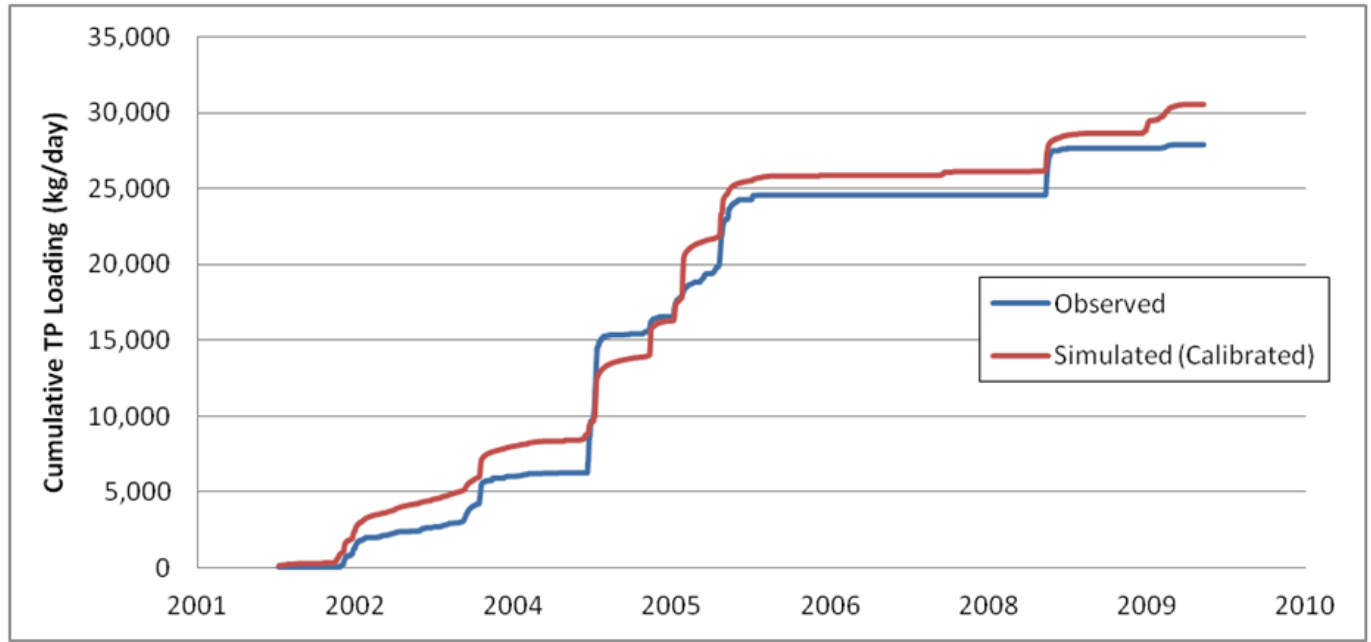

Figure A-3. Calibration results for daily (a) cumulative flow, (b) Total Phosphorus (TP) concentration, and (c) cumulative TP loading at the S-135 structure. 
(a)

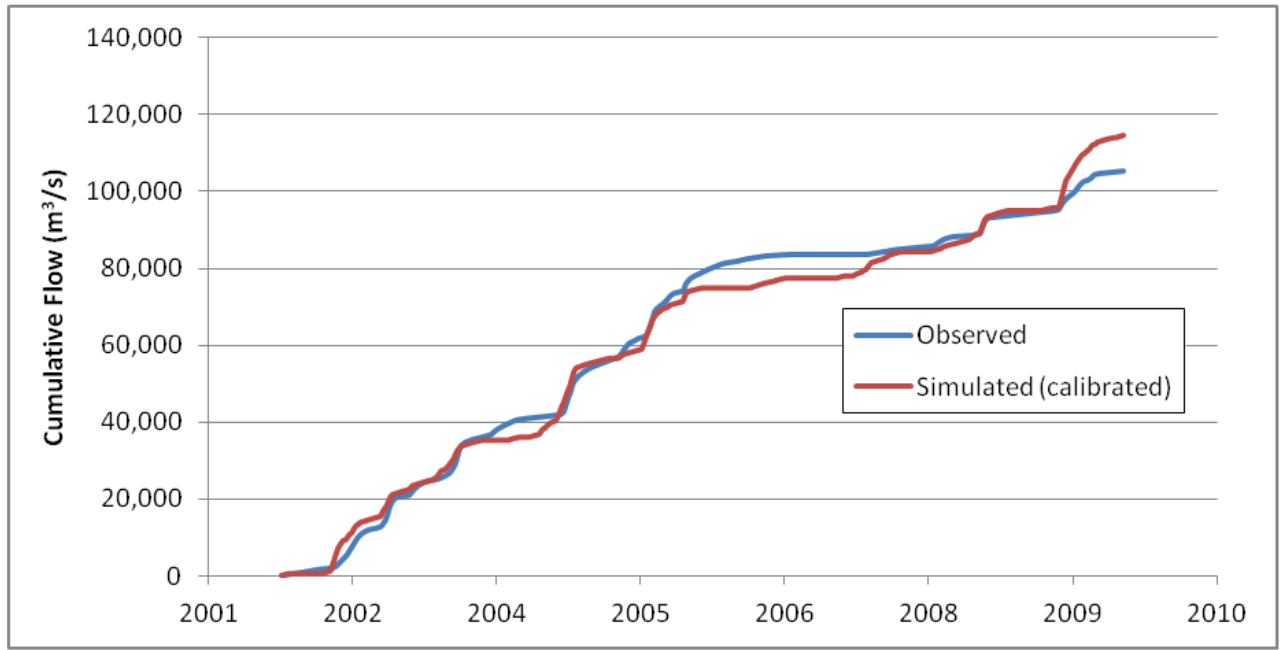

(b)

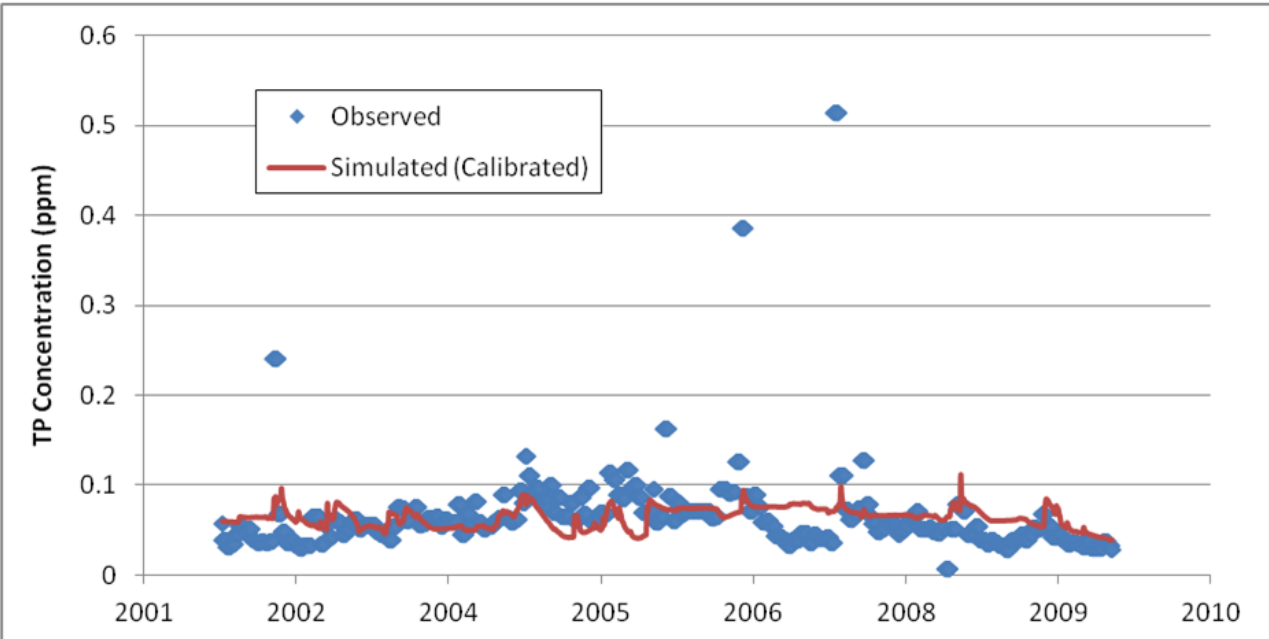

(c)

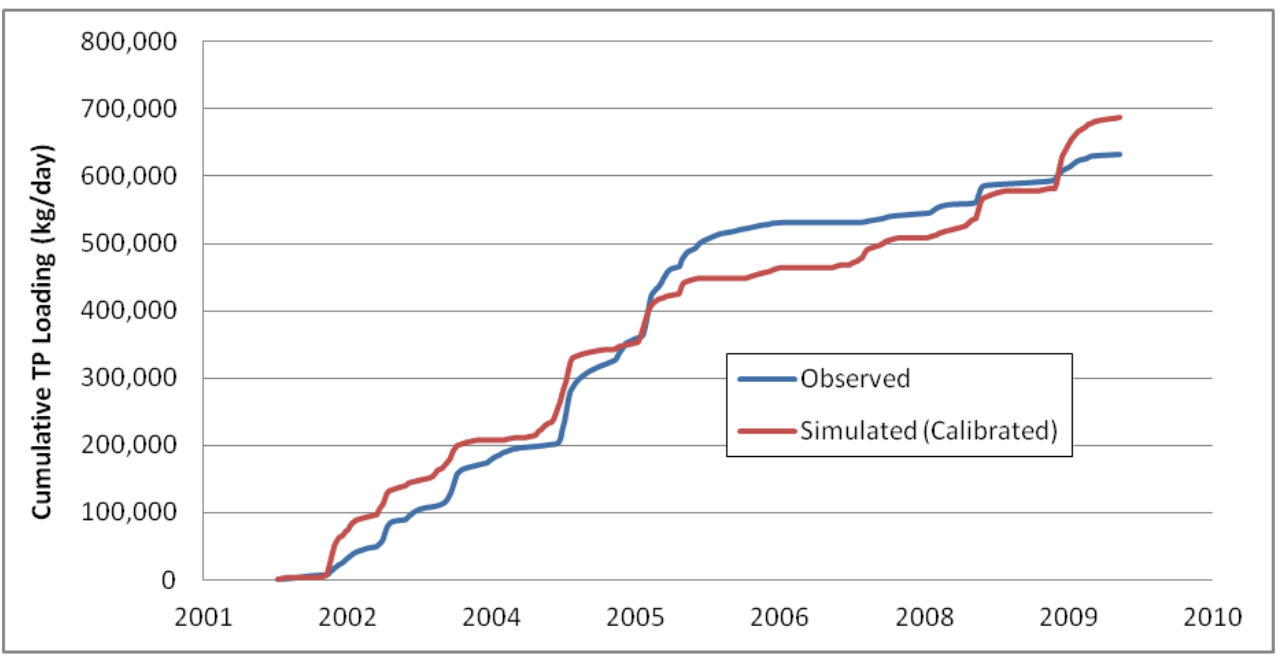

Figure A-4. Calibration results for daily (a) cumulative flow, (b) Total Phosphorus (TP) concentration, and (c) cumulative TP loading at the S-65 structure in the Upper Kissimmee sub-watershed. 
Table A-1. GOF statistical measures for monthly flow $\left(\mathrm{m}^{3} \mathrm{~s}^{-1}\right)$.

\begin{tabular}{|c|c|c|c|c|}
\hline Basin & $\begin{array}{c}\text { No. of } \\
\text { observations }\end{array}$ & $\begin{array}{l}\text { RMSE } \\
\left(\mathrm{m}^{3} \mathrm{~s}^{-1}\right)\end{array}$ & $\underset{\left(m^{3} s^{-1}\right)}{\operatorname{MBE}}$ & NSE \\
\hline & \multicolumn{4}{|c|}{ Calibration (2002 - 2004) } \\
\hline S-154 & 36 & 1.97 & -0.35 & 0.54 \\
\hline S-133 & 36 & 0.84 & 0.06 & 0.80 \\
\hline S-135 & 36 & 0.89 & 0.01 & 0.69 \\
\hline \multirow[t]{2}{*}{ UK } & 36 & 40.45 & 0.61 & 0.33 \\
\hline & \multicolumn{4}{|c|}{ Validation (2005 - 2009) } \\
\hline S-154 & 60 & 1.11 & 0.09 & 0.72 \\
\hline S-133 & 60 & 0.84 & 0.09 & 0.54 \\
\hline S-135 & 60 & 0.47 & 0.01 & 0.84 \\
\hline UK & 60 & 29.69 & 4.40 & 0.18 \\
\hline
\end{tabular}

RMSE: Root mean square error; MBE: Mean bias error; NSE: Nash-Sutcliff efficiency coefficient.

Table A-2. GOF statistical measures for monthly total phosphorus (TP) concentration $\left(\mathrm{mg} \mathrm{L}^{-1}\right)$.

\begin{tabular}{lcccc}
\hline \multicolumn{1}{c}{ Basin } & $\begin{array}{c}\text { No. of } \\
\text { observations }\end{array}$ & $\begin{array}{c}\text { RMSE } \\
\left(\mathbf{m g ~ L}^{-1}\right)\end{array}$ & $\begin{array}{c}\text { MBE } \\
\left.\text { (mg L }^{-1}\right)\end{array}$ & NSE \\
\hline S-154 & 34 & Calibration (2002 & $-2004)$ \\
S-133 & 35 & 0.25 & -0.013 & -0.55 \\
S-135 & 36 & 0.13 & 0.05 & -0.60 \\
UK & 36 & 0.06 & 0.004 & 0.38 \\
& 59 & 0.02 & 0.002 & 0.19 \\
S-154 & 59 & 0.26 & 0.05 & -0.61 \\
S-133 & 58 & 0.12 & -0.01 & 0.27 \\
S-135 & 58 & 0.05 & 0.01 & -0.03 \\
UK & \multicolumn{5}{c}{0.04} & -0.002 & 0.07 \\
\hline RMSE: Root mean square error; MBE: Mean bias error; NSE: Nash-Sutcliff \\
efficiency coefficient.
\end{tabular}


Table A-3. GOF statistical measures for monthly total phosphorus (TP) load (kg day ${ }^{-1}$ ).

\begin{tabular}{lcccc}
\hline \multicolumn{1}{c}{ Basin } & $\begin{array}{c}\text { No. of } \\
\text { observations }\end{array}$ & $\begin{array}{c}\text { RMES } \\
\left.\text { (kg day }^{-1}\right)\end{array}$ & $\begin{array}{c}\text { MBE } \\
\left.\text { (kg day }^{-1}\right)\end{array}$ & NSE \\
\hline S-154 & 36 & 172.44 & -34.22 & 0.44 \\
S-133 & 36 & 47.17 & -1.16 & 0.69 \\
S-135 & 36 & 22.37 & -1.57 & 0.70 \\
UK & 36 & 263.38 & 23.16 & 0.47 \\
& \multicolumn{4}{c}{ Validation (2005 - 2009) } \\
S-154 & 60 & 93.34 & 23.42 & 0.55 \\
S-133 & 60 & 18.90 & 0.49 & 0.78 \\
S-135 & 60 & 11.45 & 2.35 & 0.60 \\
UK & 60 & 238.37 & 15.38 & 0.13 \\
\hline
\end{tabular}

RMSE: Root mean square error; MBE: Mean bias error; NSE: Nash-Sutcliff efficiency coefficient.

Table A-4. Calibrated parameters for the in-stream attenuation analysis.

\begin{tabular}{|c|c|c|c|c|}
\hline \multirow[b]{2}{*}{ Basin } & \multicolumn{2}{|c|}{ Soluble P } & \multicolumn{2}{|c|}{ Sediment $\mathbf{P}$} \\
\hline & $\begin{array}{c}a \\
\left(\mathrm{~m} \mathrm{~s}^{-1}\right)\end{array}$ & $\begin{array}{c}C_{b} \\
\left(\mathrm{mg} \mathrm{L}^{-1}\right)\end{array}$ & $\begin{array}{c}a \\
\left(\mathrm{~m} \mathrm{~s}^{-1}\right)\end{array}$ & $\begin{array}{c}C_{b} \\
\left(\mathrm{mg} \mathrm{L}^{-1}\right)\end{array}$ \\
\hline Initial value & 0.00015 & 0.02 & 0.0015 & 0.05 \\
\hline S-154 & 0.00005 & 0.02 & 0.0015 & 0.01 \\
\hline S-133 & 0.00005 & 0.025 & 0.00005 & 0.008 \\
\hline S-135 & 0.00005 & 0.02 & 0.00015 & 0.01 \\
\hline S-191 & 0.00015 & 0.02 & 0.0015 & 0.02 \\
\hline UK & 0.00015 & 0.01 & 0.00015 & 0.008 \\
\hline
\end{tabular}

P: Phosphorus; $a$ : Rate of load transfer coefficient; $C_{b}$ : Stream background concentration.

References

SWET, 2011b. Watershed assessment model documentation and validation. Task 4 final report submitted to the South Florida Water Management District, Soil and Water Engineering Inc., Gainesville, FL. 
VITA

\section{JULIANA CORRALES}

Born, Medellín, Colombia

2001-2006

B.S., Environmental Engineering Universidad de Medellín

Medellín, Colombia

2004-2005

Facility Tour Guide

Empresas Públicas de Medellín

Medellín, Colombia

2005-2006

2009-2010

Environmental and Social Intern

Interconexión Eléctrica S.A.

Medellín, Colombia

M.S., Environmental Engineering

Florida International University

Miami, Florida

2009-2010

Teaching Assistant

Florida International University

Miami, Florida

2010

Water Quality Intern

Everglades Foundation

Miami, Florida

2010

Research Assistant

Applied Research Center at Florida International University Miami, Florida

$2011-2015$

Doctoral Candidate

Research Assistant

Florida International University

Miami, Florida

2014

Dissertation Year Fellowship

Florida International University

Miami, Florida 


\section{PUBLICATIONS AND PRESENTATIONS}

Corrales, J., Naja, G.M., Dziuba, C., Rivero, R.G., and Orem, W.H. (2011). Sulfate Threshold Target to Control Methylmercury Levels in Wetland Ecosystems. Science of Total Environment, 409: 2156 - 2162.

Corrales, J., and Naja, G.M. (March, 2011). Nutrient Exchange Program in Lake Okeechobee Watershed. Oral presentation at the Northern Everglades Interagency Meeting, South Florida Water Management District Service Center, Okeechobee, FL.

Corrales, J., Naja, G.M., Rivero, R.G., Miralles-Wilhem, F., and Bhat, M.G. (2013). Water Quality Trading Programs towards Solving Environmental Pollution Problems. Irrigation and Drainage Journal, 62 (Suppl.2): 72 - 92.

Corrales, J., Naja, G.M., Bhat, M.G., and Miralles-Wilhelm, F. (December, 2013). Cost-benefit Assessment of a Phosphorus Credit Trading Program in an Agricultural Watershed. Oral presentation at the Inter-American Development Bank Meeting. Washington, DC.

Corrales, J., Naja, G.M., Bhat, M.G., and Miralles-Wilhelm, F. (2014). Modeling a Phosphorus Credit Trading Program in an Agricultural Watershed. Journal of Environmental Management, 143: 162 - 172.

Corrales, J. (March, 2014). Modeling a Phosphorus Credit Trading Program in an Agricultural Watershed. Oral presentation at the Florida International University Annual Scholarly Forum, Miami, FL.

Corrales, J., Naja, G.M., Bhat, M.G., and Miralles-Wilhelm, F. (December, 2014). A Phosphorus Credit Trading Program in an Agricultural Watershed. Paper presented at the ACES Conference, Washington, DC.

Corrales, J., Naja, G.M., Bhat, M.G., and Miralles-Wilhelm, F. (April, 2015). Environmental and Economic Benefits of a Water Quality Trading Program in a Northern Lake Okeechobee Basin. Poster presented at the GEER Conference, Coral Springs, FL. 